\title{
PROCESSO LEGISLATIVO ESTADUAL
}

\section{CAP. 1 INTRODUÇÃO}

1.1 A importância do tema e sua delimitação

Muito embora analistas jurídicos da Constituição de 1988 proclamem virtuoso o modelo federativo engendrado pelo constituinte originário, com a criação do Município como mais um ente federativo e adoção de critérios de cooperação entre os entes, há um fenômeno conhecido como esvaziamento da competência legislativa dos Estados-membros, notadamente acentuado no âmbito das competências legislativas das Assembléias Legislativas. Confirmam-no também reiteradas decisões do Supremo Tribunal Federal de viés centralizador fundamentadas no princípio da simetria, fragilizando os já fragilizados Estados-membros da Federação brasileira.

O fenômeno da perda de competência legislativa dos Estados-membros não é novo, eis que se inicia com a reforma constitucional de 1926, mas está se acentuando cada vez mais, mercê do sistema de repartição de competências engendrado pelo constituinte de 1988 e também em razão de decisões do Pretório Excelso, mitigando-se assim o papel do Poder Legislativo estadual, quer como arauto de novas experiências que aos Estados-membros deveria ser reservado num sistema federativo, quer como centro de tomada de decisões de questões de interesse regional, que igualmente deveria ser dinamizado e fortalecido, notadamente em matérias de competência legislativa concorrente e suplementar.

O comando constitucional obrigando os Estados a observarem os princípios previstos na Constituição Federal comprova ou afasta uma absoluta simetria no federalismo brasileiro? Ora, se se admitir que na organização dos Estados Federados a simetria com os princípios da Constituição Federal deve ser absoluta, então não há falar em Estado federativo, mas em Estado unitário dividido em regiões administrativas; máxime no processo legislativo estadual, com Assembléias Legislativas unicamerais, necessariamente assimétricas com a organização do Poder Legislativo federal, bicameral. 
Buscar-se-á, pois, examinar o processo legislativo estadual previsto nas Constituições Estaduais e nos Regimentos Internos das Assembléias Legislativas à luz dos preceitos da Constituição de 1988, notadamente o da autonomia dos Estadosmembros e dos princípios gerais da dinâmica do processo legislativo, isto é, do procedimento legislativo. Imbricam sobre o tema outros tão amplos quanto o do processo legislativo estadual, como o do sistema de repartição de competências adotado pelo constituinte federal; o controle de constitucionalidade dos atos normativos estaduais; o da representação parlamentar; o da técnica legislativa e que, embora às vezes superpostos ao que se propõe analisar, apenas subsidiarão o que resta, então, delimitado: processo legislativo estadual.

\subsection{Método}

A pesquisa jurídica adotará como método de trabalho a análise da doutrina e da jurisprudência, inclusive de decisões internas das Casas Legislativas efetivadas por seus órgãos no âmbito do direito parlamentar e, ao que puder interessar à investigação, utilizar-se-á também de dados estatísticos sobre efetivação, pelas Assembléias Legislativas, de suas funções constitucionais precípuas.

A par da visão histórica da evolução dos Legislativos regionais no Brasil designadamente, investigar-se-á o tema sob uma perspectiva dogmático-jurídica, esta a abordagem metodológica.

Pretende-se, assim, indicar subsídios em perspectiva a melhores práticas no processo legislativo estadual e, quiçá, para atividade jurisdicional de controle dos atos parlamentares e da lei, em busca de uma autonomia mais alargada dos Estadosmembros e de uma maior efetividade das competências legislativas deste ente na federação brasileira.

\subsection{Plano do trabalho}

A presente pesquisa, afora o desta Introdução, está estruturada em nove capítulos. Assim, o capítulo 2 relata um iter da evolução histórica do Poder Legislativo, acentuando suas principais características e o delineamento na Europa, durante a Idade Média, das Assembléias Representativas, e as contribuições ao princípio representativo nos moldes hoje conhecidos. Registra-se, outrossim, o surgimento do Poder Legislativo 
francês e do norte-americano frisando-se, em conclusão, princípios do direito constitucional parlamentar que até então foram sedimentados. Ainda neste segundo capítulo, apontam-se as competências e organização das primeiras Casas Legislativas brasileiras, as Câmaras Municipais durante o período colonial e as Câmaras de Escabinos sob o domínio colonial holandês. Acerca dos Legislativos regionais, há pesquisa fundamentada em Atas de Assembléia Geral, do Arquivo Real de Haya, para afirmar que em 1640 houve "a primeira assembléia legislativa de que se tem notícia no Novo Mundo”, ocorrida no Nordeste brasileiro sob o domínio neerlandês. Discorre-se, ainda, sobre as Juntas Gerais no período colonial, que consistiam em reuniões de Câmaras Municipais. Já no Império, gizam-se as composições e parcas competências dos Conselhos Gerais de Províncias, transformados em Assembléias Legislativas Provinciais, a partir de 1834, estas sim com competência legislativa, forjando-se, a partir daí, certa autonomia provincial. Durante a Constituição Federal de 1891 anota-se o auge da autonomia dos Estados-membros e, ao mesmo tempo, o declínio dessa autonomia com o advento da Reforma Constitucional de 1926. Faz-se, enfim, um relato histórico das Assembléias Legislativas estaduais na Federação brasileira, até a Constituição de 1969, sob a perspectiva jurídico-constitucional da autonomia dos Estados-membros e designadamente das competências do Poder Legislativo estadual. Finalizando o capítulo, expõem-se a estrutura, composição e funcionamento das atuais Assembléias Legislativas.

No capítulo 3 analisam-se as diretrizes do sistema de repartição de competências adotado no modelo federativo brasileiro, identificando-se o apoucamento da autonomia dos Estados-membros.

O capítulo 4 tem por escopo apresentar o processo legislativo como instrumento para a consecução de várias funções do Poder Legislativo, não apenas a legislativa ou a fiscalizadora. Aí se expõem as funções do Poder Legislativo, conceituação, objeto e finalidade do processo legislativo, além de sua fundamentação constitucional, princípios e regras que o regem e dos seus pressupostos materiais e formais. Procura-se apontar, desde já, algumas peculiaridades do processo legislativo estadual em relação ao federal para, no capítulo seguinte, discorrer sobre as espécies normativas previstas e não previstas nas Constituições dos 26 Estados-membros, e os titulares da iniciativa legislativa, anotando-se peculiaridades variadas em relação do modelo federal, notadamente a iniciativa popular. 
No capítulo 6 analisa-se a dinâmica dos procedimentos legislativos estaduais: padrão, abreviado, sumário e especial. Nos capítulos seguintes (7 a 9), discorre-se sobre as peculiaridades das fases procedimentais fixadas nas Constituições e Regimentos Internos, desde a apresentação de uma proposição, com anotações sobre técnica legislativa, ou legística, até os efeitos da deliberação de um órgão colegiado, como é a Assembléia. Questões sobre sanção, veto, promulgação e publicação no processo legislativo estadual são analisadas à luz da doutrina e jurisprudência dos tribunais, procurando-se enfatizar eventuais exorbitâncias praticadas por Legislativo Estadual desbordando de sua autonomia fixada constitucionalmente, bem assim as interpretações dos tribunais acerca de princípios constitucionais cerceando a autonomia estadual e ceifando competências explícitas ou implícitas dos Legislativos Estaduais. A perspectiva é a do controle jurisdicional da atuação do Poder Legislativo, notadamente no processo legislativo estadual, analisando-se, então, a iniciativa legislativa privativa, possibilidade de emenda parlamentar a proposições, limites ao poder de legislar, princípio do devido processo legislativo, normas constitucionais federais de observância obrigatória pelas Constituições Estaduais, leis autorizativas, limite do prazo de discussão, questões atinentes à votação (quorum, escrutínio secreto, voto de liderança, reserva de Plenário), obstrução parlamentar legítima e direito das minorias, oferecendo-se, então, conclusões.

\subsection{Tese}

O objeto deste trabalho consiste em analisar o processo legislativo previsto em Constituições estaduais e Regimentos Internos das Assembléias Legislativas à luz da Constituição Federal de 1988, que não prevê expressamente o processo legislativo federal como princípio de observância compulsória para os Estados-membros, perscrutando-se a seguinte tese: na dimensão de sua autonomia, os Estados-membros da Federação brasileira nem sempre estão sujeitos à fidedigna, irrestrita e compulsória observância, por simetria, de princípios e regras do processo legislativo federal.

\subsection{Contribuição original da tese à ciência jurídica brasileira}

Desenvolvida a pesquisa prevalentemente sob o influxo da linha do federalismo, pretende-se nela suscitar questões acerca da adequação de decisões judiciais tomadas no âmbito do controle dos atos do Poder Legislativo Estadual às disposições constitucionais conformadoras da organização e competências deste Poder, 
eis que fundamentadas (as decisões judiciais) no amplo e genérico princípio da simetria que os Estados-membros deveriam observar na consecução das funções precípuas do Poder Legislativo Estadual com as do Federal.

Indagar-se-á sobre os rumos da conformação do modelo brasileiro de Federação, centralizador de competências para a União em detrimento dos Estadosmembros, acentuadamente em prejuízo do Poder Legislativo Estadual.

E procurar-se-á investigar em ordem a demonstrar se há um processo legislativo estadual, peculiar, não adstrito a todos os preceitos que informam o processo legislativo federal. 


\section{Cap. 2 PODER LEGISLATIVO}

Como condição de admissibilidade do procedimento de formação das leis estaduais e dos procedimentos do Legislativo Estadual necessários à consecução de suas demais funções, põe-se, intransponível, pela sua própria essencialidade, a existência e o funcionamento do próprio Poder Legislativo Estadual. ${ }^{1}$ Denominadas Assembléias Legislativas, atualmente, são vinte e seis, ${ }^{2}$ e foram sendo forjadas, instituídas e instaladas no decorrer da evolução do Estado brasileiro, que absorveu, em sua constituição, os valores da representação parlamentar.

\footnotetext{
${ }^{1}$ SILVA, José Afonso da. Processo constitucional de formação das leis. 2. ed., São Paulo: Malheiros, 2006, p. 261. Demais condições de admissibilidade do procedimento de formação das leis: i)apresentação do projeto; $i$ ) existência de quorum para deliberar; iii) Ordem do Dia.
}

2 1) Bahia, 2) Pernambuco, 3) Rio de Janeiro, 4) São Paulo, 5) Minas Gerais, 6) Rio Grande do Sul, 7) Alagoas, 8) Ceará, 9) Espírito Santo, 10) Goiás, 11) Maranhão, 12) Mato Grosso, 13) Paraíba, 14) Piauí, 15) Rio Grande do Norte, 16) Santa Catarina, 17) Sergipe, 18) Pará, 19) Amazonas, 20) Paraná, 21) Acre, 22) Mato Grosso do Sul, 23) Rondônia, 24) Amapá, 25) Roraima e 26) Tocantins.

Oswaldo Trigueiro ( ${ }^{1}$ ) informa que "ao tornar-se independente, o Brasil estava dividido em 19 Províncias, e essa divisão, com pequenas alterações, foi mantida pelo Império. De início, esse número caiu para 18, quando o Brasil perdeu a Cisplatina, em virtude do Tratado de Montevidéu, firmado em 1828. Anos depois, foi elevado para vinte, com a criação da Província do Amazonas (Lei de 5 de setembro de 1850), no território da antiga Capitania de São José do Javari, depois São José do Rio Negro; e da do Paraná (Lei de 29 de agosto de 1853) desmembrada da Província de São Paulo. Essas 20 Províncias foram, em 1889, transformadas nos vinte Estados com que se fundou a república, sob o regime federativo".

Além dos 20 Estados fundadores, o antigo território do Acre foi elevado à categoria de Estado (art. $9^{\circ}$ do ADCT da Constituição de 1946 e Lei n. 4.070, de 15 de junho de 1962).

Entre 1960 e 1975 “o número de Estados elevou-se a vinte e dois. Com a mudança da Capital da República para o Planalto Central, como previsto nas Constituições republicanas (1891, art. $3^{\circ}$; 1934, art. $4^{\circ}$ do ADCT; 1946, art. $4^{\circ}$ do ADCT), exceto a de 1937, o antigo Município neutro da Província do Rio de Janeiro, onde se instalara a sede da Monarquia, converteu-se no Estado da Guanabara, que desapareceu em 1975, em virtude da fusão determinada pela Lei Complementar n. 20, de 1 de julho de 1974. Em 11 de outubro de 1977, a Lei Complementar n. 31 desmembrou do antigo Estado de Mato Grosso o Estado de Mato Grosso do Sul, ficando aquele com a designação de Mato Grosso do Norte.

No período republicano, as alterações territoriais não foram numerosas, nem importantes. O Estado Novo não organizou outros Estados, mas criou 6 Territórios: o de Iguaçu, em área desmembrada dos Estados do Paraná e Santa Catarina; o de Ponta Porã, em área desmembrada de Mato Grosso; o de Rondônia, em área de Mato Grosso e do Amazonas; o de Rio Branco (Roraima), desmembrado do Amazonas; o do Amapá, em área retirada do Estado do Pará; além do Território insular de Fernando de Noronha, que antes pertencia ao Estado de Pernambuco. A Constituinte de 1946 desfez os Territórios de Iguaçu e Ponta Porá."

O Estado de Rondônia foi criado pela Lei Complementar n. 41, de 22 de dezembro de 1981, mediante elevação do Território do mesmo nome.

O constituinte de 1988 transformou os Territórios do Amapá e de Roraima em Estados Federados (art. 14 do ADCT); extinguiu o Território Federal de Fernando de Noronha, sendo sua área reincorporada ao Estado de Pernambuco (art. 15 do ADCT); e criou o Estado de Tocantins por desmembramento de área de Goiás (art. 13 do ADCT).

${ }^{1}$ Direito Constitucional Estadual. Rio de Janeiro: Forense, 1980, p. 15-16; 23. 
Em História do Legislativo Brasileiro - Assembléias Legislativas, Vamireh Chacon acentua que "o itinerário do Poder Legislativo no tempo e espaço implica também o crescente processo de autoconscientização da liberdade”. Registra, ainda, que "o Poder Legislativo significa, em última instância, um poder coletivo de determinada sociedade. Por mais que parlamentares se destaquem, trata-se do poder menos individual, mais perigosamente instável, porém, mais potencialmente construtivo. Sua paralisação, interna ou externa, resulta em sua liquidação". 3

Sob a perspectiva das dificuldades que acompanham, até os dias atuais, o polêmico tema da representação política ${ }^{4}$, Jean-Jacques Rousseau já sentenciava, em defesa da democracia direta, que o primeiro passo para a perda da liberdade de um povo é dado quando ele nomeia representantes. ${ }^{5}$

Apologista das eleições, Montesquieu, em outro sentido, fundamentava a necessidade da representação política no pressuposto da incapacidade de o povo estar preparado para tratar de uma gama crescente de assuntos técnicos complexos, próprios da atividade governamental: "A grande vantagem dos representantes é que são capazes de discutir os negócios públicos. O povo não é, de modo algum, capaz disso, fato que constitui um dos graves inconvenientes da democracia". 6

$\mathrm{Na}$ democracia constitucional, restou incontroverso que às assembléias parlamentares foi assegurado lugar como instituição co-partícipe do arranjo da representação política da sociedade. É pelo caráter representativo das assembléias, com natureza de órgãos decisórios, que também se implementa a vontade popular em

\footnotetext{
${ }^{3}$ CHACON, Vamireh; RODARTE, Claus. História do Legislativo Brasileiro - Assembléias Legislativas. Brasília: Senado Federal, vol. V, 2007, p. 3.

${ }^{4}$ SARTORI, Giovanni. A teoria da representação no Estado representativo moderno. Belo Horizonte: Revista Brasileira de Estudos Políticos, 1962.

${ }^{5}$ Para Jean-Jacques Rousseau "a soberania não pode ser representada, pela mesma razão que não pode ser alienada; ela consiste essencialmente na vontade geral, e a vontade de modo algum se representa; ou é a mesma ou é outra; não há nisso meio termo." Segundo o autor, o primeiro passo para a perda da liberdade é dado quando se nomeia representantes: "Os deputados do povo não são, pois, nem podem ser seus representantes; são quando muito seus comissários e nada podem concluir definitivamente. O povo inglês pensa ser livre, mas está completamente iludido; apenas o é durante a eleição dos membros do Parlamento; tão logo estejam estes eleitos, é de novo escravo, não é nada." ROUSSEAU, Jean-Jacques. O Contrato Social. São Paulo : Ed. Cultrix, 1971, p. 96.
}

${ }^{6}$ MONTESQUIEU. Do Espírito das Leis. São Paulo: Ed. Abril, 1973, p. 158.

Ainda no cap. VI do Livro Décimo Primeiro da clássica obra referenciada: "Havia um grande vício na maior parte das antigas repúblicas, pois que nelas o povo tinha direito de tomar resoluções ativas que exigem certa execução, coisa de que é inteiramente incapaz. Ele só deve participar do governo para escolher seus representantes, procedimento para o qual é bastante capaz.”, p. 158. 
governos democráticos contemporâneos, pressupondo-se que a vontade política do povo tornar-se-á expressa por intermédio da vontade de seus representantes.

Nesse sentido, Miguel Reale adverte para a concepção de um Poder Legislativo ideal, porquanto não deixa de ser “a imagem do povo que o elegeu”. ?

Constata-se hoje em dia, como salienta Alexandre de Moraes, que o "Poder Executivo vem assumindo, cada vez mais, o papel de grande empreendedor das políticas governamentais, relegando a segundo plano o Parlamento". ${ }^{8}$

Não obstante observar-se o acentuado declínio do Legislativo em meados do século passado, "não é verdade que Parlamentos e Congressos sejam uma espécie em extinção," afiança Tércio Sampaio Ferraz Jr., "ao contrário, quanto maior a complexidade social do mundo moderno, tanto mais importante é sua presença."

E, malgrado a indiscutível crise de legitimidade da representação política decorrente também dos inúmeros sistemas eleitorais adotados pelos povos, as assembléias parlamentares, periodicamente eleitas em processo competitivo de escolha, multiplicaram-se pelo mundo, como corolário da necessidade de haver, no sistema representativo, uma instituição forjada nos moldes do próprio Parlamento para abrigar a vocação democrática dos povos. Nessa perspectiva, confira-se a relação dos Parlamentos no mundo, respectiva estrutura e composição parlamentar, na excelente pesquisa feita por Monica Herman Salem Caggiano, ${ }^{10}$ que, sobre a importância dos Parlamentos ou Congressos, fundadamente, também constata:

"Quer nos sistemas parlamentaristas, quer nos sistemas presidencialistas ou ainda nos quadros híbridos, o parlamento, hoje, é presença constante no mundo da política, em razão da sua natureza representativa, de suas atividades de controle, de sua competência financeira e orçamentária ou, até mesmo, da produção legislativa. Não mais merece ser ignorado ou marginalizado. É instituição importante e de relevo na atmosfera estatal, reconquistando o seu espaço, como denota o processo de redemocratização presente no território africano e no Leste Europeu, o qual sempre tem sido iniciado com a convocação de eleições para a composição do respectivo parlamento e a este têm se

\footnotetext{
${ }^{7}$ Reforma Constitucional. In Revista de Direito Público. São Paulo : Ed. Revista dos Tribunais, n. 8, abr./jun., 1969, p. 11.

${ }^{8}$ Jurisdição constitucional e tribunais constitucionais; garantia suprema da constituição. São Paulo :Atlas, 2000.

9 Democracia e Participação. In Curso de Introdução à Ciência Política. Brasília: Editora Universidade de Brasília, 1979, p. 63.

${ }^{10}$ Direito Parlamentar e Direito Eleitoral. Barueri-SP: Manole, 2004, p. 44-69.
} 
oferecido estrutura e organização que atendem aos mais modernos figurinos". 11

Na evolução política do Estado brasileiro, o Poder Legislativo foi previsto por todas as Constituições e sempre esteve em funcionamento, exceto durante o Estado Novo e por alguns outros curtos períodos, mantendo-se presente na cena das decisões políticas. Assim, subtraindo a dissolução, em 12 de novembro de 1823, dos trabalhos da Assembléia Constituinte e Legislativa, por 11 vezes foi dissolvida a Câmara dos Deputados durante o período imperial. ${ }^{12}$ Costa Porto apresenta o seguinte "quadro de legislaturas e dissoluções no Império":
“(...) $4^{\mathrm{a}}$ ) 1841 - 1842 (dissolvida por decreto de $1^{\mathrm{o}}$ de maio de 1842)
$5^{\mathrm{a}}$ ) 1843 - 1844 (dissolvida por decreto de 24 de maio de 1844)
(...) $7^{\text {a }}$ ) 1848 - (dissolvida por decreto de 19 de fevereiro de 1849)
(...) $11^{\mathrm{a}}$ ) $1861-1864$ (dissolvida por decreto de 12 de maio de 1863)
(...) $13^{\mathrm{a}}$ ) $1867-1868$ (dissolvida por decreto de 18 de julho de 1868)
$14^{\mathrm{a}}$ ) 1869 - 1872 (dissolvida por decreto de 22 de maio de 1872)
(...) $16^{\underline{a}}$ ) $1877-1878$ (dissolvida por decreto de 11 de abril de 1878)
$17^{\mathrm{a}}$ ) 1878 - 1881 (dissolvida por decreto de 30 de junho de 1881)
$18^{\mathrm{a}}$ ) 1882 - 1884 (dissolvida por decreto de 3 de setembro de 1884)
$19^{\mathrm{a}}$ ) 1885 - (dissolvida por decreto de 26 de setembro de 1885)
$20^{\mathrm{a}}$ ) 1886 - 1889 (dissolvida por decreto de 17 de junho de 1889)."

Durante o período republicano, os atos ditatoriais de fechamento do Congresso decorrentes de conflito entre Poderes e perpetrados pelo Executivo ocorreram em 1891, 1930, 1937, 1966, 1968 e 1977, como abaixo é mostrado, sendo que houve dissolução das Casas Legislativas e extinção de todos os mandatos parlamentares em 1930 e 1937.

Fechamento do Legislativo:

- $\underline{\mathbf{1 8 9 1}}$ - Decreto $\mathrm{n}^{\mathrm{O}}$ 641, de 3 de novembro de 1891, editado pelo "Presidente da República dos Estados Unidos do Brazil", Manoel Deodoro da Fonseca, "dissolve o Congresso Nacional, convoca a Nação para escolher novos representantes e toma outras providências". O Decreto no 641 foi "anulado" pelo Decreto $\mathrm{n}^{\mathrm{o}}$ 686, de 23 de novembro de 1891, editado pelo Vice-Presidente da República, Floriano Peixoto, em virtude da renúncia do Presidente Manoel Deodoro da Fonseca.

- $\underline{\mathbf{1 9 3 0}}$ - Decreto $\mathrm{n}^{\mathrm{o}} 19.398$, de 11 de novembro de 1930, editado pelo "Chefe do Governo Provisório da República dos Estados Unidos do Brasil", Getúlio Vargas: "Institui o Governo Provisório da República dos Estados Unidos do

\footnotetext{
${ }^{11}$ Idem, p. 6-7.

${ }^{12}$ Idem, p. 110-124.
} 
Brasil e dá outras providências". O artigo $2^{\text {o }}$ do Decreto $\mathrm{n}^{\mathrm{o}}$ 19.398/30 estabelecia: "É confirmada, para todos os efeitos, a dissolução do Congresso Nacional, das atuais Assembléias Legislativas dos Estados (quaisquer que sejam as suas denominações), Câmaras ou Assembléias municipais e quaisquer outros órgãos legislativos ou deliberativos, existentes nos Estados, nos Municípios, no Distrito Federal ou Território do Acre, e dissolvidos os que ainda o não tenham sido de fato."

- $\underline{\mathbf{1 9 3 7}}$ - A Constituição, outorgada por Getúlio Vargas em 10 de novembro de 1937, determinava em seu artigo 178: "São dissolvidos nesta data a Câmara dos Deputados, o Senado Federal, as Assembléias Legislativas dos Estados e as Câmaras Municipais. As eleições do Parlamento nacional serão marcadas pelo Presidente da República, depois de realizado o plebiscito a que se refere o art. 187."

- $\underline{1966}$ - Ato Complementar $\mathrm{n}^{\mathrm{o}}$ 23, de 20 de outubro de 1966, editado pelo Presidente da República, Humberto de Alencar Castello Branco, ordenava: "Art. $1^{\underline{0}}$ - Fica decretado o recesso do Congresso Nacional a partir desta data até o dia 22 de novembro de 1966."

- $\mathbf{1 9 6 8}$ - Ato Complementar no 38, de 13 de dezembro de 1968, editado pelo Presidente da República, Arthur Costa e Silva, decidia: “Art. 1ํ- Nos termos do art. $2^{-}$e seus parágrafos do Ato Institucional $\mathrm{n}^{\circ}$ 5, de 13 de dezembro de 1968, fica decretado o recesso do Congresso Nacional, a partir desta data." O Ato Complementar $\mathrm{n}^{\mathrm{o}}$ 72, de 15 de outubro de 1969, "baixado" pela Junta Militar composta pelos Ministros Augusto Rademaker, Aurélio de Lyra Tavares e Márcio de Souza Mello, estabelecia: “Art. 1ํㅡ - Fica suspenso, a partir de 22 de outubro corrente, o recesso do Congresso Nacional, decretado pelo Ato Complementar n⿳0 38, de 13 de dezembro de 1968."

- $\underline{\mathbf{1 9 7 7}}$ - Ato Complementar n. 102, de $1^{\mathrm{o}}$ de abril de 1977, editado pelo Presidente da República, Ernesto Geisel, determinava: “Art. 1ํㅡ - Nos termos do artigo $2^{\circ}$ e seus parágrafos do Ato Institucional $\mathrm{n}^{\mathrm{o}}$ 5, de 13 de dezembro de 1968, fica decretado o recesso do Congresso Nacional." E o Ato Complementar n⿳⺈ 103, de 14 de abril de 1977, editado pelo Presidente Ernesto Geisel, decidia: "Art. $1^{\circ}$ - Fica suspenso, a partir de 15 de abril de 1977, o recesso do Congresso Nacional decretado pelo Ato Complementar $\mathrm{n}^{\circ}$ 102, de $1^{\circ}$ de abril de 1977."

Para se demonstrar a existência e o funcionamento das atuais Assembléias Legislativas dos Estados-membros da Federação brasileira procurar-se-á anotar um dos itinerários do Poder Legislativo no tempo e no espaço vinculado ao seu surgimento em terras brasileiras. No Império, após os Conselhos Gerais, os Legislativos provinciais, criados em 1834 e instalados em 1835, eram unicamerais e receberam a denominação de Assembléias Legislativas. Já na República Velha, houve Legislativos Estaduais tanto uni quanto bicamerais, como adiante se verá, e a uniformidade da denominação viria a ocorrer a partir de 1934. Registre-se, por oportuno, que, ao contrário do 
Legislativo Nacional, já freqüentado por Senadores vitalícios no Império e também por 'biônicos' na República, as portas dos Legislativos Estaduais sempre foram abertas pelo voto do povo outorgando mandatos temporários a legítimos representantes.

\subsection{Traços históricos}

Característico da instituição parlamentar é o seu caráter representativo; seu peculiar procedimento deliberativo para adoção de opções políticas, com discussão pública e posterior votação, também pública, mediante escrutínio ostensivo ou, excepcionalmente, secreto; e a natureza preponderantemente legislativa de suas decisões. Esses elementos podem ser encontrados na maioria das Assembléias ou Parlamentos $^{13}$, órgãos colegiados que se afirmam pela igualdade entre seus membros para consecução do Estado Democrático de Direito; eis que, por emanar da vontade popular os mandatos outorgados aos membros do Poder Legislativo, nele se reforça a dimensão democrática do próprio Estado de Direito.

As assembléias com caráter representativo, informam os historiadores, surgiram somente no mundo medieval, com os concílios católicos e os conselhos municipais. $^{14}$

O historiador e cientista político S. E. Finer, professor na Universidade de Oxford, em sua obra A História do Governo, aponta as Assembléias Representativas como um dos maiores legados, a "grande invenção política da Idade Média". 15 Assinala que "durante os séculos XIII e XIV, quando as cidades livres e as repúblicas italianas se estavam a encaminhar para a sua época mais próspera, dava-se uma transformação radical dos reinos e principados. Começando com a Espanha, depois com a Inglaterra, a França e a Itália, espalhando-se depois para a Alemanha, a Escandinávia e até à Polônia e Hungria, eis que brotava uma multidão de corpos conciliares para darem o seu consentimento - mas também - pelo mesmo motivo -

${ }^{13}$ Cf. COTTA, Maurizio, Parlamento, in Dicionário de Política, BOBBIO, Norberto; MATTEUCCI, Nicola e PASQUINO, Gianfranco; tradução Carmen C. Varriale... [et al.]. 5. ed., Brasília : Edit. Universidade de Brasília, 2000, v. 2., p. 878. HAURIOU, Maurice, Principios de Derecho Público y Constitucional, tradução de Carlos Ruiz del Castillo, 2. ed., Madrid : Instituto Editorial Reus, s.d., p. 385. S.E.P.E.S. - Servicio Español del Profesorado de Enseñanza Superior, La Estrutura del Estado. Barcelona : Bosch, Casa Editorial, 1958, p. 80.

${ }^{14}$ S.E.P.E.S. - Servicio Español del Profesorado de Enseñanza Superior. La Estrutura del Estado. Barcelona : Bosch, Casa Editorial, 1958, p. 78. FRIEDRICH, Carl J. Gobierno constitucional y democracia. Madrid : Instituto de Estudios Politicos, v. II, 1975, p. 12.

${ }^{15}$ A História do Governo: as épocas intermédias. Portugal: Publicações Europa-América, 2004, v. 2, p. 1081 . 
para exercerem um certo controlo sobre os seus governantes. Alguns países, como a Inglaterra, a Irlanda, a Escócia, Sicília, Estados Papais e o grande Reino de Nápoles chamavam-lhes parlamentos ou parlamenti. Na Península Ibérica, chamavam-se cortes ou corts. Em França e nos Países Baixos tinham o nome de Estados ou Estados Gerais. Na Alemanha chamavam-se landtage, na Dinamarca e na Noruega, a assembléia era o Rigsdag, na Suécia, o Riksdag e na Polônia, o Sejm”. ${ }^{16}$ Como primeira característica comum, Finer cita que "todas elas eram assembléias políticas compostas pelos representantes da ordem ou ordens privilegiadas de um país, que actuavam em nome dessas ordens e de todo o país, por um lado, para vigiarem a manutenção dos privilégios das ordens, grupos e indivíduos e, por outro, para oferecerem ao príncipe a contrapartida dos direitos e privilégios reconhecidos e por ele concedidos”. A segunda característica, observa o autor, era a de "serem instituições regulares e não arranjos $a d$ hoc como a magna concilia feudal que existira antes". ${ }^{17}$

A idéia central, enfatiza Finer, era a de pars pro toto. Esclarece, ainda, o historiador de Oxford que, tanto o Parlamento inglês como outros que nele foram encontrar parâmetro, se basearam no princípio da representatividade "e este princípio era absolutamente novo".

Sob essa perspectiva, igualmente, Karl Loewenstein afirma que "a invenção ou descobrimento da técnica de representação foi tão decisiva para o desenvolvimento político do Ocidente e do mundo, como foram para o desenvolvimento técnico da humanidade a invenção do motor a vapor, a eletricidade, o motor de explosão ou a energia atômica. Um governo é sempre indispensável para um sociedade estatal organizada. Mas foi a técnica da representação que tornou possível a instituição do parlamento como detentor de um poder separado e independente do governo. (...) Sem a introdução do princípio da representação, o poder político teria permanecido monolítico indefinidamente, como assim ocorreu fora do mundo ocidental até que finalmente nestes territórios o absolutismo sucumbiu ao tomar contato com a idéia do Constitucionalismo liberal". ${ }^{18}$

Os parlamentos europeus surgem, pois, no âmbito da estrutura policêntrica do sistema feudal, onde o rei costumava convocar periodicamente os

\footnotetext{
${ }^{16}$ Idem, p. 1081.

${ }^{17}$ Id. p. 1081.

${ }^{18}$ Teoria..., ob. cit. p. 60 .
} 
senhores dos feudos e o alto clero para reunião, com o escopo de receber deles, além de aconselhamento, contribuições em dinheiro e prestação de serviço pessoal. ${ }^{19}$ É da ininterrupta evolução dessas assembléias que se origina o Parlamento inglês, Mater Parliamentorum, que superou o absolutismo do rei, controlando-o, e servindo "de inspiração e de modelo a todos os grandes Parlamentos do mundo". ${ }^{20}$

Desde a assim considerada criação da Câmara dos Comuns, em 1265, por Simon de Montfort, inúmeros outros princípios do direito parlamentar foram sendo sedimentados durante o processo evolutivo do Parlamento: a) funcionamento permanente em legislaturas - ao se estabelecer a obrigatoriedade da realização de eleições antes do término do mandato parlamentar institucionaliza-se a perenidade do Poder Legislativo -, em locus próprio e independentemente de convocação externa corporis; b) mandato parlamentar livre; c) imunidades parlamentares; d) sistema parlamentar de trabalho com singular metodologia decisional; e) funções: representativa, legislativa, de participação da imposição tributária, de investigação, de controle, jurisdicional; f) estrutura independente dos órgãos internos; g) responsabilidade política no sistema parlamentar de governo. ${ }^{21}$

${ }^{19}$ De acordo com os historiadores, as primeiras assembléias representativas vinculam-se à admissão dos burgueses, membros das classes livres das cidades e das vilas, aos corpos políticos deliberantes, junto dos nobres e dos prelados. "Parece que isso ocorreu pela primeira vez em Aragão em 1163, e imediatamente em Lião (1188) e em Castela (1250). O Parlamento siciliano reuniu-se pela primeira vez em 1232; (...) em 1302 ocorreu pela primeira vez a reunião dos Estados Gerais, na França." Cf. S.E.P.E.S., ob. cit. p.78.

20 ANDRADE, Almir de. A evolução política dos parlamentos e a maturidade democrática : o exemplo modelar do parlamento inglês, in Revista de Informação Legislativa. Brasília : Senado Federal, ano 21, n. 81, jan./mar., 1984, p.63.

21 ANDRADE, Almir de. A evolução política dos parlamentos e a maturidade democrática - O exemplo modelar do Parlamento inglês, in Revista de Informação Legislativa. Brasília : Senado Federal, ano 21, n. 81, jan./mar. 1984, p. 41-118. BRITTO, Luiz Navarro de. História dos parlamentos: um esboço, in Revista de Informação Legislativa, Brasília : Senado Federal, a. 21, n. 81, jan./mar., 1984, p. 119-131. BISCARETTI DI RUFFIA, Paolo. Direito constitucional: instituições de direito público. São Paulo : Ed. Revista dos Tribunais, 1984, p. 237-380. CAGGiAno, Monica Herman Salem. Direito Parlamentar e Direito Eleitoral. Barueri,SP : Manole, 2004, p. 1-69. Idem, Parlamento no cenário político do século XXI, in Revista do Advogado, São Paulo : AASP, n. 73, nov./2003, p.146-166. CANOTILHO, José Joaquim Gomes. Direito Constitucional e Teoria da Constituição. 5. ed. Coimbra : Almedina, 2002, p.621-633. COTTA, Maurizio, Parlamento, in Dicionário de Política, BOBBIO, Norberto; MATTEUCCI, Nicola e PASQUINO, Gianfranco; tradução Carmen C. Varriale... [et al.]. 5. ed., Brasília : Edit. Universidade de Brasília, 2000, v. 2., p. 877-888. DOMINGUES, Francisco Caamaño. El mandato parlamentario. Madrid : Congreso de los Diputados, 1991. FERRAZ JR. Tércio Sampaio. Democracia e Participação, in Curso de Introdução à Ciência Política, Brasília : Editora Universidade de Brasília, 1979, p. 5389. FERREIRA FILHO, Manoel Gonçalves, Do processo..., ob. cit. Idem, O parlamentarismo. São Paulo : Saraiva, 1993. FIGUEIREDO, Paulo de. O Poder Legislativo nas civilizações desaparecidas, in Revista de Informação Legislativa. Brasília : Senado Federal, ano 18, n. 71, jul./set. 1981, p. 4394. FINER, S.E. A História do Governo: as épocas intermédias. Portugal: Pub. Europa-América, 2004, v. 2, p. 1081-1108. MALBERG, R. Carré de. Teoría general del Estado. México : Fondo de 
Constatação comum dos estudiosos sobre o assunto reside no fato de que o Parlamento da Inglaterra, teorizado por John Locke e Montesquieu, tornar-se-á referência, irradiando-se para outras nações que se constituiriam em Estados democrático-constitucionais no mundo moderno, sob a égide de uma representação política legítima. Um século antes da Revolução Francesa, a Inglaterra já consolidara um modelo de democracia representativa oponível ao absolutismo monárquico.

O pensamento iluminista fundamentado na razão sedimentou a teoria de Montesquieu de separação de poderes, inspirada nas instituições políticas inglesas, celebrizada no Capítulo VI do Livro XI do Espírito das Leis. ${ }^{22}$ Esta obra inspiraria, por sua vez, e decididamente, os federalistas Hamilton, Madison e Jay, bem como Thomas Jefferson, na conformação do modelo de democracia constitucional representativa após a independência dos Estados Unidos da América, quando, pelo “Tratado de Paris" firmado em 1783, a independência de treze das Colônias foi reconhecida pelos ingleses, após a "Declaração de Independência" redigida por Thomas Jefferson e que havia sido promulgada pelo "Congresso de Filadélfia", ocorrido em $1775-6 .^{23}$

Representação política de um povo no corpo da "Câmara de Representantes", o Parlamento foi assim previsto na primeira Constituição escrita, a Constituição de 1787 dos Estados Unidos da América. Treze das colônias americanas, aproveitando o legado histórico do governo representativo inglês, acolhem-no de maneira inovadora mediante criação do sistema presidencialista e tripartição de poderes: Legislativo, Executivo e Judiciário.

Cultura Económica, 1998, p. 247-426. OLIVEIRA FILHO, João de. Legislativo: Poder Autêntico. Rio de Janeiro : Forense, 1974. S.E.P.E.S. - Servicio Español del Profesorado de Enseñanza Superior, La Estrutura del Estado. Barcelona : Bosch, Casa Editorial, 1958. SOUZA, José Pedro Galvão de. Da Representação Política. São Paulo : Saraiva, 1971. SILVA, José Afonso. Processo constitucional de formação das leis. São Paulo: Malheiros, 2. ed., 2006. SPROESSER, Andyara Klopstock. Direito Parlamentar - processo legislativo. 2. ed. São Paulo : ALESP/SGP, 2004. TELLES JÚNIOR, Gofredo. Um Poder Legislativo Autêntico. In Revista de Direito Público. São Paulo : Ed. Revista dos Tribunais, n. 14, out./dez., 1970 p. 17-27.

${ }^{22}$ MONTESQUIEU. Do Espírito das Leis. Tradução de Fernando Henrique Cardoso e Leôncio Martins Rodrigues, São Paulo : Ed. Abril, 1973, pp. 156-162.

${ }^{23}$ Dalmo Dallari observa que "a leitura do Livro XI, Capítulo VI, da obra célebre de Montesquieu, 'De L'Esprit des Lois', e seu confronto com a Constituição norte-americana, revela ter havido muito mais do que simples coincidências. O ponto de partida do notável teórico francês é a recomendação relativa a separação de poderes, o que foi religiosamente seguido pelos americanos. Depois disso há uma série de recomendações, quanto às características e às atribuições dos poderes, que foram quase todas acolhidas." Cf. Elementos..., ob. cit. p. 203. 
Sob a perspectiva de uma representatividade legítima surge, igualmente, na mesma época do norte-americano, o Legislativo francês; todavia, decorrente de violenta e sangrenta ruptura com o absolutismo monárquico. Em 1789, os representantes dos três 'estados' da sociedade francesa (clero, nobreza e burguesia), reunidos em Estados Gerais, constituíram-se em Assembléia Nacional, em seguida transformada em Assembléia Nacional Constituinte, proclamaram, em 26 de agosto de 1789, a Declaração dos Direitos do Homem e do Cidadão, e, em 3 de setembro de 1791, promulgaram a Constituição francesa. Mediante expressa disposição constitucional, o Poder Legislativo na França foi delegado à Assembléia Nacional composta de "representantes temporários, livremente eleitos pelo povo, para ser exercido por ela, com a sanção do rei” (Tít. III, art. $3^{\circ}$ ). Os componentes da Assembléia Nacional Legislativa eram representantes da Nação, desvinculando-se a vontade do representante eleito da vontade dos eleitores do Departamento de origem, abolindo-se expressamente, o mandato imperativo (Tít. III, cap. I, seção III, art. $7^{\circ}$ ), ${ }^{24}$ que se contrapunha ao ideal iluminista de liberdade, e que, juntamente com a igualdade e a fraternidade, inspiraram o movimento revolucionário francês.

Registre-se, pois, que a Revolução Americana e a Francesa lançaram os alicerces da nova estruturação do Estado e de um ordenamento jurídico fundado na supremacia da Lei sobre todos, tendo no seu ápice uma Constituição como Lei Maior. As conquistas dessas revoluções liberais contagiaram inúmeras colônias espanholas e a portuguesa na América, impulsionando movimentos de independência no início do século XIX, com a conseqüente adoção de regimes constitucionais pelos novéis países latino-americanos, como o Brasil, e.g., implementados mediante modelos de democracias representativas fundados notadamente no mandato parlamentar.

\subsection{Câmaras Municipais e Câmaras de Escabinos no Brasil}

No Brasil colonial, os primeiros órgãos colegiados de representação política foram as Câmaras Municipais, também denominadas Conselhos Municipais ou Senado da Câmara.

\footnotetext{
${ }^{24}$ MIRANDA, Jorge. Textos históricos do Direito Constitucional. Lisboa : Imprensa Nacional, 1990, p. 63.
} 
Na Vila de São Vicente, em 1532, Martim Afonso de Sousa instalou, após eleições na forma prevista no Título XLV das Ordenações Manuelinas, a primeira Câmara Municipal em território americano. ${ }^{25}$

Acerca das funções das Câmaras Municipais, anota Affonso Celso:

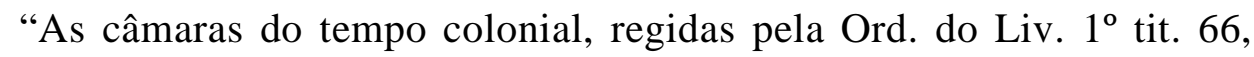
tinham a administração dos bens do conselho, faziam obras, estabeleciam posturas, marcavam taxas, impunham fintas. Em virtude de outras ordenações e leis posteriores nomeavam: os juízes almotacés; os recebedores da siza; os depositários públicos; os avaliadores dos bens penhorados; os alcaides; quadrilheiros; capitães-mores de ordenanças; sargentos-mores; capitães-mores de estradas e assaltos, ou capitães do mato; os juízes da vintena; e os tesoureiros menores e intervinham no julgamento das injúrias verbais. Além dessas atribuições dadas por lei, arrogavam-se outras mais importantes e também mais perigosas: promoviam a guerra e a paz com os gentios; decretavam a criação de arraiais; convocavam juntas do povo para discutir e deliberar sobre interesses da capitania; exigiam que os governadores comparecessem nos seus paços para tratar com elas negócios públicos, e mais de uma vez suspenderam-os e nomearam quem os substituísse, enquanto o Governo não providenciasse a respeito.

A metrópole reagiu; obrigou-as a restringirem-se às suas atribuições, impôs-lhes formal obediência aos governadores, permitindo-lhes apenas replicarem respeitosamente às suas ordens, quando lhes parecessem ilegais, executando-as, se reiteradas, e representando ao governo de Lisboa, para resolver como entendesse de justiça. Ficaram, portanto, reduzidas à expressão simples de corporações locais, circunscritas nos limites traçados pela legislação vigente." 26

De conformação aristocrática, eram constituídas por membros natos e por representantes eleitos dentre os 'homens-bons' (boni-homines) ${ }^{27}$, forjando-se aí as

${ }^{25}$ LEMBO, Cláudio. Cronologia básica do Direito Eleitoral Brasileiro. In: LEMBO, Cláudio; CAGGIANO, Monica Herman Salem. (Coord.) O voto nas Américas. Barueri, SP: Minha Editora; São Paulo: Cepes, 2008, p. 73.

${ }^{26}$ Reforma Administrativa e Municipal. Rio de Janeiro: Typographia Nacional, 1883, p.78-79.

27 "Homens bons incluía os nobres de linhagem e seus descendentes; os senhores de engenho, a alta burocracia civil e militar e seus descendentes. A esse grupo, se juntavam os 'homens novos', burgueses que o comércio enriquecera." Cf. PORTO, Walter Costa. História eleitoral do Brasil. Brasília : Gráfica do Senado Federal, 1989, p. 10.

Relata Rodolfo Garcia: "As câmaras compunham-se de um juiz, seu presidente nato; três ou quatro vereadores, segundo o foral ou costume da terra, que, nessa parte, foram respeitados pelas Ordenações Filipinas; um escrivão e um procurador, e, em alguns lugares, um tesoureiro. Todos esses membros tomavam o nome de oficiais da Câmara." Ensaio sobre História Política e Administrativa do Brasil (1500-1810). Rio de Janeiro: Liv. José Olympio, 1956, p. 97. 
primeiras experiências de mandato representativo em terras brasileiras. Apesar do limitado corpo eleitoral previsto na legislação portuguesa das Ordenações Manuelinas (1514) e Filipinas (1603), os analfabetos não eram impedidos de votar. ${ }^{28} \mathrm{O}$ processo eleitoral transcorria da seguinte forma:

"Reunido o conselho, os homens bons da terra e o povo, o juiz lhes pedia que nomeassem seis homens para eleitores. Essa eleição era feita em escrutínio secreto, para que uns não soubessem quais os nomeados pelos outros. Apurados os votos pelo juiz e vereadores, eram proclamados eleitores os seis mais votados; depois de juramentados eram divididos em três turmas de dois eleitores cada uma, de modo a não haver comunicação entre eles. Cada turma apresentava um rol contendo os nomes dos que queriam eleger para juízes, vereadores, escrivães e mais oficiais, para servirem por três anos. Esses róis deviam ser assinados pelos membros das turmas; mas quando algum não sabia escrever, um juiz ou vereador podia assinar por ele, prestando juramento de segredo. O presidente da eleição examinava os três róis; verificava quais os nomes mais votados, e escrevia-os em uma folha que se denominava pauta, devendo providenciar que não servissem conjuntamente no mesmo ano parentes dentro do quarto grau por direito canônico. A isso se chamara apurar a pauta. Assinada, era fechada e selada. Em seguida formava o juiz três pelouros para juízes, três para vereadores e assim para cada ofício. Pelouros de vereação convém definir - eram os papéis em que estavam escritos os nomes das pessoas que deviam servir de juízes, vereadores etc., e chamavam-se assim porque eram encerrados em bolas de cera, que tinham a forma de pelouro (bala de ferro para arma de fogo) (...) Os pelouros eram metidos em um saco contendo tantos compartimentos quantos eram os oficiais; em um compartimento especial guardava-se a pauta, que servia para por ela verificar-se, no fim dos três anos, se tinha havido ou não alguma falsidade ou violação dos pelouros. (...) $\mathrm{O}$ saco dos pelouros era guardado em uma arca ou cofre de três chaves, cujos claviculários eram os três vereadores do ano findo. O claviculário que confiasse a chave a quem quer que fosse, a pena que tinha era o degredo por um ano fora da vila. (...) Chegada a época de tirar os pelouros, o que dependia dos costumes e forais, sendo geralmente no dia 1 de janeiro, presentes os oficiais da câmara, homens bons e povo, um menino, isto é, um moço de idade até sete anos, na frase das Ordenações - tirava de cada compartimento um pelouro, sendo proclamados oficiais aqueles cujos nomes nele estivessem escritos.",29

\footnotetext{
28 "Do voto, não era excluído o analfabeto: dispunha-se, expressamente, que, não sabendo os eleitores escrever, 'ser-lhes-á dado um homem bom, que com eles escreva com juramento, que não descubra o segredo da eleição'." Cf. PORTO, Walter Costa. História eleitoral do Brasil. Brasília : Gráfica do Senado Federal, 1989, p. 10.

${ }^{29}$ Rodolfo Garcia, ob. cit., p. 97-99.
} 
Outra organização municipal com caráter representativo ocorreu no Nordeste brasileiro sob a dominação holandesa. Francisco Adolfo de Varnhagen relata que "em lugar das nossas câmaras municipais, com seus juízes e vereadores, se instalaram, desde 1636, em todas as vilas, com analogia ao que tinha lugar na província de Holanda, câmaras de escabinos", com atribuições administrativas e judiciárias. ${ }^{30}$ Seus membros eram eleitos anualmente em eleições de três graus: "O conselho de justiça elegia os eleitores, estes organizavam as listas dos indivíduos aptos para serem membros das câmaras, e sobre essas listas o Conselho Supremo escolhia os escabinos". 31 Varnhagen assinala que a composição destas câmaras variava "segundo a importância das povoações, de três a nove, e cada uma das duas nacionalidades portuguesa ou holandesa, em separado, tinha igual número, sendo, porém, ordinariamente holandês o esculteto que a presidia; o que dava sempre a maioria em favor dos dominadores". ${ }^{32}$ E Frei Manoel Calado afiança que as Câmaras dos escabinos compunham-se de quatro juízes portugueses e quatro flamengos. ${ }^{33}$

\subsection{Legislativos regionais brasileiros}

Além de instituições políticas locais, há fontes primárias históricas comprovando que existiram em terras brasileiras, antes de 1824, órgãos colegiados político-representativos em âmbito regional, predecessores dos Conselhos Gerais e das Assembléias Legislativas provinciais.

\subsubsection{A Assembléia Legislativa dos Escabinos e as Juntas Gerais no período colonial}

Durante o período colonial, em terras brasileiras, há registros de instituições com caráter representativo regional. Em 1640, no Nordeste, sob o domínio dos holandeses, os historiadores dão conta da "primeira assembléia legislativa de que se tem notícia no Novo Mundo". ${ }^{34}$ Referem-se à Assembléia de Escabinos, convocada por João Maurício, conde de Nassau, e encontra-se registrada nas "Actas da Assembêa

\footnotetext{
${ }^{30}$ Historia Geral do Brasil: antes de sua separação e independência de Portugal. 10. e.d. integral, revisão e notas. J. Capistrano de Abreu e Rodolfo Garcia. Belo Horizonte:Ed Itatiaia, São Paulo: Ed. Universidade de São Paulo, 1981. Vol. 1, Tomo II, p. 289.

${ }^{31}$ Idem. Cf. nota de Rodolfo Garcia.

${ }^{32}$ Idem. p. 289

${ }^{33}$ O Valeroso Lucideno. São Paulo: Edições Cultura, 1943, p. 68.

${ }^{34}$ GARCIA, Rodolfo. História Política e Administrativa do Brasil. Rio de Janeiro: Liv. José Olympio Edit, 1956, p. 172. Cf. Varnhagen, op. cit., vol. 1, tomo II, p.289.
} 
Geral" "35, do Archivo Real de Haya. Para a Assembléia Geral do "Estado do Brazil" neerlandês, que reuniu-se de 27 de agosto a 4 de setembro de 1640, foram "convocados deputados" representantes de "todas as câmaras deste Estado" e do povo, todos portugueses, num total de $55 .{ }^{36} \mathrm{Da}$ ata do evento consta que "as proposições que forem aprovadas serão assinadas pelos membros da Assembléia, vigorarão como leis e serão inviolavelmente guardadas nesta República". ${ }^{37}$ Estabelecendo aos membros da assembléia regras para as votações, já se registrava razão sobre o impedimento de votar, até hoje presente em normas regimentais das Casas Legislativas: o voto "em branco". Advertia-se que ao dispor do seu voto, o Deputado não deveria "alegar razões ou fundamentos que dissessem respeito ao seu interesse particular, porquanto perniciosa coisa é dar alguém o seu voto a bem do seu proveito privado". Nas reuniões, que ocorreram sempre às "8 horas da manhã", na cidade Maurícia, os participantes tomavam assento em lugares preordenados, e não podiam ausentar-se da cidade sem licença do presidente da assembléia. Regulamentou-se que, após as proposições apresentadas pelo presidente da assembléia, e votadas, dar-se-ia oportunidade a cada um dos escabinos e dos cidadãos para que expusesse seus "apontamentos" e fizesse "as suas advertências a bem da República”. O presidente da assembléia apresentou cinco proposições, "todas tendentes ao bem da República e proveito dos moradores do Brazil", e basicamente diziam respeito à segurança tanto territorial como dos

${ }^{35}$ Revista do Instituto Archeologico e Geographico Pernambucano. Recife: Typographia Universal, vol. 5, n. 31, outubro de 1886, p. 173-238.

${ }^{36}$ Da Câmara da Cidade Maurícia: 3 escabinos (Gaspar Dias Ferreira, Gregório de Barros Pereira, Cosme de Castro Passos), 4 do povo, ou freguesia, ou comuna - gemeente - da Várzea (Bernardim de Carvalho, Antonio de Oliveira, Antonio Cavalcante, João Fernandes Vieira); 3 do povo do Cabo (Pedro Marinho Falcão, Luiz de Pena Barbosa, Miguel Paes); 4 do povo de Ipojuca (Amador de Araújo, Gaspar Pereira Landim, Francisco Dias Delgado, Paulo Pereira Morine [Amorim?] sic; 3 do povo de S. Lourenço (Gaspar da Silva, Arnáo d'Olanda, Gaspar Pereira); 4 do povo de Moribeca (Paulo de Araujo de Azevedo, Diogo de Araújo de Azevedo, Francisco de Souza Bacelar, Fernão do Valle); 2 do povo de Santo Amaro (Antonio de Bulhões, Belchior Velho); 3 do povo de Paratibe e Jaguaribe (Antonio da Rocha Beserra, Paulo Leitão d'Albuquerque, Simão Gonçalves Atalaia).

Da Câmara da Paraíba: 2 escabinos (Manoel de Azevedo, Francisco Gomes Monis), 4 do povo da Paraíba (Antonio Pinto de Mendonça, Duarte Gomes da Silveira, Manoel d'Almeida, Manoel de Queiroz Siqueira [Cerqueira?] sic).

Da Câmara de Itamaracá: 2 escabinos (Estevão Carneiro, João Garros [Garcos?] sic, 4 do povo (Francisco de Lugo, Ruy Vaes Pinto, Digo Figueira de Freitas, Domingos Pinto da Fonseca).

Da Câmara de Igaraçu: 2 escabinos (Gonçalo Novo de Lira, João Malheiro da Rocha), 4 do povo (Sebastião Vieira, Pero Ferreira Vilcarens, João Freire, João de Matos da Costa).

Da Câmara de Porto do Calvo: 2 escabinos (Francisco de Souza Falcão, Bartholomeu Lins d'Almeida); 4 do povo (Vasco Marinho Falcão, Domingos Gonçalves Masagão, Manoel de Almeida Botelho, Francisco Rabello).

Da Câmara de Serinhaém: 1 escabino (Lourenço Ferreira Betancor); 4 do povo (Miguel Ferreira de Sá, Gil Lopes, Simão Vieira, Francisco Fernandes Anjos).

${ }^{37}$ Idem. p. 177. 
moradores, e aos abusos praticados por oficiais da milícia. Após discussão de cada proposição, seguiu-se a deliberação e assinatura em ata, com acréscimo até de alguma "moderação" ou "advertência" dos membros da assembléia ao proposto por seu presidente, como ocorreu sobre a questão se conviria, ou não, aos moradores disporem de armas em suas casas. Às proposições dos dominadores, seguiram-se as propostas dos dominados sobre liberdade de culto religioso, "negócios da justiça", "matéria de guerra", polícia, economia, escravidão, banimento dos judeus ${ }^{38}$, pagamento de dívidas, planejamento agrícola. Poucas dessas propostas foram acolhidas pelo presidente da assembléia e pelo Conselho Supremo, vez que se consideravam incompetentes, prometendo que seriam submetidas à apreciação da Assembléia dos XIX. A Assembléia dos Escabinos reuniu-se somente nessa ocasião. ${ }^{39}$

O jurista e historiador Netto Campello insere tais registros como uma experiência de representação política, merecedora de constar como parte da História Parlamentar de Pernambuco, ${ }^{40}$ tornando a Assembléia dos Escabinos predecessora da Assembléia Legislativa pernambucana.

De caráter regional, igualmente, mas reunindo-se em várias ocasiões, houve no Brasil-colônia Juntas Gerais de Câmaras Municipais. É que, "nos casos graves”, as Câmaras Municipais podiam convocar "as chamadas Juntas Gerais, nas quais se deliberava à pluralidade de votos da nobreza, milícia e clero". ${ }^{41}$ Com caráter consultivo, de início, as Juntas Gerais conquistaram poder deliberativo e podiam ser convocadas pelo governador também. As cartas régias posteriores ao regimento de André Vidal de Negreiros (1655), reconhecem, ainda que implicitamente, "o poder das juntas, e não fizeram mais do que respeitar os fatos consumados", conclui Rodolfo Garcia $^{42}$, observando também que as deliberações do colegiado ordinariamente eram assistidas pelos "governadores, capitães-mores e oficiais de justiça e fazenda".

\footnotetext{
${ }^{38}$ Idem, p. 228.

${ }^{39}$ Observa Rodolfo Garcia, ob. cit. p. 175: “A Assembléia dos escabinos só se reuniu nesse ano de 1640. Foi uma experiência que falhou para os dominadores, aliás, nesse sentido, bem intencionados. Ainda houve mais ou menos paz e tranqüilidade pública no resto do período de Nassau; depois foi a guerra acesa, a luta de cada dia, e não havia tempo para se cuidar do governo civil, que só o governo de Marte devia imperar, dos dois lados, até a epopéia final de 1654."

40 História parlamentar de Pernambuco. Recife: Imprensa Industrial, 1923. Edição fac-similar: Recife: Assembléia Legislativa do Estado de Pernambuco, 1979, p. 3-50.

${ }^{41}$ Rodolfo Garcia, ob. cit. p. 104

${ }^{42}$ Ob. cit. p. 105.
} 
Claus Rodarte, discorrendo sobre a história da Assembléia Legislativa mineira, anota o seu peculiar processo de formação vinculado às Juntas Gerais de Distritos, as quais, inclusive, precederam os legislativos municipais mineiros:

"O Poder Legislativo em Minas, nascido com as assembléias do povo no período revolucionário da Guerra dos Emboabas, oficializado na forma de câmaras municipais pelo Governador Antônio de Albuquerque, teve ainda uma originalidade que distinguiu Minas das demais capitanias: as Juntas das Minas (posteriormente, Junta das Câmaras das Minas). Essa experiência supra-municipal, de caráter mais consultivo do que propriamente deliberativo, porém igualmente importante no processo legislativo, foi importante na preparação política dos mineiros. João Camilo de Oliveira Torres, em sua obra História de Minas Gerais, registra vinte Juntas realizadas entre 1710 e 1735, dizendo que só cessariam de ser convocadas em 1750, (...) A primeira Junta ocorreu aos 17 de julho de 1710 (antes mesmo da criação dos legislativos municipais mineiros) e contou com a participação dos então distritos do Rio das Velhas, Caeté, Sabará, Ouro Preto, Ribeirão de N. Sra do Carmo e Rio das Mortes. Participaram da primeira Junta os cinco vigários da vara, um superintendente, cinco capitães-mores, cinco sargentos-mores, os procuradores da Fazenda Real e vinte e quatro homens bons (quatro de cada distrito). Com a criação dos poderes municipais mineiros, as Juntas passaram a contar com a representação de cada município." 43

João Camilo de Oliveira Torres, ao frisar que, de 1710 a 1735, "realizaramse umas vinte Juntas em Minas", concluiu que "correspondia a quase um parlamento permanente". Registrou, outrossim, a natureza reivindicatória das Juntas em face do império português, ao referir-se às Juntas realizada em 24 de março de 1734: "Nestas juntas houve quem dissesse verdades desagradáveis aos ouvidos de velhos servidores" do Reino. E como o principal assunto referia-se ao quinto, alude ao seguinte conselho do procurador do Reino à Sua Majestade: "É coisa que não conseguirá da Junta. (...) As minas foram achadas e povoadas sem auxílio algum da Fazenda de sua Majestade. Contente-se, portanto, com o que quiser o povo dar-lhe à conta dos quintos e com o direito de fabricar a moeda". ${ }^{4}$

\subsubsection{Os Conselhos Gerais e as Assembléias Legislativas Provinciais no período imperial}

\footnotetext{
${ }^{43}$ História do Legislativo Brasileiro - Assembléias Legislativas. Brasília: Senado Federal, vol. V, 2008, p. 64.

${ }^{44}$ História de Minas Gerais, p. 259.
} 
O Poder Legislativo nas Províncias do período imperial brasileiro estava composto pelos Conselhos Gerais, designadamente órgãos consultivos. No capítulo V do título IX da Carta outorgada em 1824 cuidava-se "Dos Conselhos Gerais das Províncias e suas atribuições”. Aos cidadãos reconhecia-se o direito de intervir nos negócios de suas respectivas Províncias atinentes a seus interesses peculiares (art. 71). Nas Províncias mais populosas “como Pará, Maranhão, Pernambuco, Bahia, Minas Gerais, São Paulo e Rio Grande do Sul”, fixava a composição dos Conselhos Gerais em 21 membros e 13 nas demais (art. 73), sendo eleitos da mesma forma como se procedia com os Representantes da Nação, e pelo mesmo mandato de 4 anos (art. 74), dentre cidadãos brasileiros (art. 95) maiores de 25 anos, probos e de "decente subsistência" (art. 75). Os projetos de lei e as resoluções dos Conselhos Gerais de Província eram enviados à Assembléia Geral bicameral do Império para definitiva deliberação das proposições (arts. 82-85). Estando em recesso a Assembléia Geral, as proposituras deveriam ser conduzidas diretamente ao Imperador pelos respectivos presidentes de Províncias, e "sua Majestade Imperial" poderia anuir com sua imediata execução ou não. Vê-se aí marcas do viés centralizador que caracterizava o Estado unitário de então.

A Carta do Império seria alterada em 1834, mediante Ato Adicional (Lei n. 16, de 12 de agosto de 1834) aprovado somente pela Câmara dos Deputados, substituindo-se os Conselhos Gerais de Província pelas Assembléias Legislativas Provinciais, com competências legislativas.

De fato. A Carta outorgada pelo Imperador permitia revisão após quatro anos do seu juramento. A proposta de alteração deveria ter origem na Câmara dos Deputados, apoiada por um terço dos seus membros (art. 174). Depois de lida por três vezes a intervalos de seis dias e deliberado que poderia ser admitida à tramitação, emitir-se-ia decreto convocando os eleitores para conferirem aos Deputados, na seguinte legislatura, especial faculdade para a pretendida alteração (arts. 175-176).

Agenor de Roure informa: "foi a 6 de maio de 1831, sete anos depois de jurada a Constituição do Império, que surgiu na Câmara a idéia da revisão constitucional. Miranda Ribeiro (depois Visconde de Uberaba) requereu a nomeação de uma comissão especial" para propor a reforma constitucional nos moldes previstos nos artigos 174 a $178 .{ }^{45}$ Somente na primeira sessão da legislatura seguinte, caso os eleitores tivessem confiado "especial faculdade para a pretendida alteração ou

\footnotetext{
${ }^{45}$ Formação Constitucional do Brasil. Rio de Janeiro: Typ. Do Jornal do Commercio, 1914, p. 205.
} 
reforma", é que se discutiria então a reforma constitucional. Foi o que ocorreu. A legislatura de 1834-1837 obtivera dos eleitores "especial faculdade para a pretendida alteração ou reforma”. A Câmara dos Deputados discutiu e votou o projeto de revisão e não o remeteu ao Senado, que considerou ilegal o Ato Adicional elaborado só pela Câmara. Sobre a questão relatou Roure:

"Uma comissão especial de 5 membros, composta dos Srs. Visconde de Cayru, Diogo Feijó, Visconde da Pedra Branca, Paula Souza e Marquez de Caravellas, deu parecer sobre o caso, havendo divergências que foram resolvidas pela maioria com o reconhecimento da legalidade do procedimento da Câmara e do Ato Adicional. Nem podia ser de outro modo. Quando a Câmara não mandou ao Senado o projeto de revisão, foi exatamente para obedecer a Constituição, cujo art. 176 exigia, para votar a revisão, que OS DEPUTADOS de uma NOVA LEGISLATURA recebessem poderes especiais do eleitorado. Não falava em Senado e nem o Senado vitalício podia ter NOVA LEGISLATURA ou receber NOVO MANDATO com os poderes especiais. Era mesmo à Câmara e só à Câmara que cabia votar a revisão e enviá-la à publicação sem passar pelo Senado, como fora por ela resolvido, por 70 votos contra $\underline{16}$.

A votação e discussão do Ato Adicional durou três meses - 5 de Maio a 6 de Agosto de 1834 - tendo dado parecer uma comissão especial composta dos Srs. Vasconcellos, Paula Araujo e Limpo de Breu e sendo adotada a lei por 64 votos contra 20. Discutiu-se se devia ser assinado por todos os Deputados ou se apenas pela Mesa, indo uma comissão de 24 membros levá-lo à Regência. Adotado este último alvitre, em nome da deputação falou no Paço o Deputado Limpo de Abreu, dizendo que a revisão constitucional que acabava de ser feita era há muito reclamada pelo progressivo incremento da civilização e das luzes e pelas crescentes necessidades das províncias. Fora votada com o princípio federal amplamente desenvolvido, apenas com aquelas modificações que eram filhas do estudo e da experiência das nações mais cultas. Era a monarquia sustentada por instituições populares. A Regência, em nome de Pedro II, respondeu estar convencida de que a reforma constitucional 'preencheria a espectação da grande família brasileira' e louvou muito o zelo e a sabedoria da Câmara." ${ }^{46}$

Abrandando o rigorismo centralizador daquele Estado unitário foi editado o Ato Adicional de 1834. Assim, as Assembléias Legislativas Provinciais adquiriram competência para legislar sobre divisão civil, judiciária e eclesiástica; instrução pública; desapropriação por utilidade municipal ou provincial; polícia e economia municipal mediante propostas das Câmaras Municipais; fixação das despesas municipais e provinciais e impostos necessários à Província; criação e supressão de

${ }^{46}$ Idem, p. 206-207. 
empregos municipais e provinciais; obras públicas, estradas e navegação no interior da respectiva Província; construção de casas de prisão, trabalho e correção; casas de socorros públicos (art. 10 do Ato Adicional de 1834).

Com mandato parlamentar de 2 anos, fixou-se em 36 o número de membros das Assembléias Legislativas nas Províncias de Pernambuco, Bahia, Rio de Janeiro, Minas Gerais e São Paulo; em 28 nas do Pará, Maranhão, Ceará, Paraíba, Alagoas e Rio Grande do Sul; e em 20 nas demais, "alterável por Lei Geral". Poderia ainda a Assembléia Geral do Império, por solicitação de Assembléia Legislativa Provincial, aprovar a criação de uma "segunda Câmara", com "duração maior que a primeira" (art. $3^{\circ}$ do Ato Adicional de 1834). Sobre o Senado na Província, se seria necessário dividir o Poder Legislativo Provincial em duas Câmaras, Affonso Celso registra que “ao discutir-se o Ato Adicional, propôs-se na Câmara a instituição do Senado, desde logo, nas províncias do Rio de Janeiro, Minas Gerais, São Paulo, Pernambuco e Bahia. Mais tarde as assembléias de São Paulo e Pernambuco representaram pedindo a criação da $2^{\text {a }}$ câmara e não foram atendidas". ${ }^{4}$ Sobre essa questão Affonso Celso aduz:

"As câmaras provinciais não são assembléias políticas às quais o entusiasmo de momento ou paixões partidárias possam ditar resoluções perigosas, capazes de mudarem a face da província, destruindo interesses firmados e criando sérias complicações. Sua tarefa é legislar sobre a administração local, e nesta esfera ainda o maior erro não pode produzir logo males consideráveis, difíceis de remediar-se. Além de que a sanção presidencial e a atribuição que tem a Assembléia Geral de revogar suas leis, quando ofensivas da Constituição, dos impostos gerais, direitos de outras províncias e dos tratados com as nações estrangeiras, dão salutares garantias contra os mais graves abusos que possam praticar, - é outro corretivo aos seus desmando a curta duração do mandato.

Ao cabo de dois anos, é de supor que elas componham-se de novo pessoal, devendo-se, portanto, esperar que não duvidem revogar qualquer lei prejudicial à província. Se, porém, esta reeleger os mesmos representantes, os outros que entendam não reparar o desacerto de seus antecessores, então o que se deve concluir é - ou que a lei tem utilidade, ou que realmente a província a quer e nesse caso... res sua agitur. A lei, na sua missão de proteger e prevenir, não pode ir ao ponto de amparar interesses que, tendo em si próprios recursos eficazes, não os aproveitam, ou deles não sabem fazer uso.

Por outro lado, a criação de uma segunda câmara traria grande aumento de despesa, a que não poderiam as províncias ocorrer sem

47 Reforma Administrativa e Municipal. Rio de Janeiro: Typographia Nacional, 1883, p. 53. Cf. também Castro Nunes. As Constituições estaduais do Brasil. Ob. cit., p. 60. 
sacrifícios, não compensados pelas vantagens prováveis da instituição." 48

O viés descentralizador do Ato Adicional de 1834, todavia, sofreu revés decorrente da edição da Lei de interpretação ao Ato, Lei de n. 105, de 12 de maio de 1840.

\subsubsection{Assembléias Legislativas estaduais na Federação}

Os legisladores constituintes brasileiros, desde 1891 até 1988, criaram e mantiveram um Estado federativo. Vale dizer, há uma união indissociável das partes, Estados-membros, que vão haurir em uma Constituição Federal a matriz de sua autoorganização, autogoverno e auto-administração. Alexandre de Moraes salienta que numa Federação, cuja base jurídica deflui de uma Constituição, devem ficar assentes os seguintes princípios:

- “os cidadãos dos diversos Estados-membros aderentes à Federação devem possuir nacionalidade única dessa;

- repartição constitucional de competências entre a União, Estadosmembros, Distrito Federal e município;

- necessidade de que cada ente federativo possua uma esfera de competência tributária que lhe garanta renda própria;

- poder de auto-organização dos Estados-membros, Distrito Federal e municípios, atribuindo-lhes autonomia constitucional;

- possibilidade constitucional excepcional e taxativa de intervenção federal, para manutenção do equilíbrio federativo;

- participação dos Estados no Poder Legislativo Federal, de forma a permitir-se a ingerência de sua vontade na formação da legislação federal;

- possibilidade de criação de novo Estado ou modificação territorial de Estado existente dependendo da aquiescência da população do Estado afetado;

- a existência de um órgão de cúpula do Poder Judiciário para interpretação e proteção da Constituição Federal."49

${ }^{48}$ Reforma administrativa... p.54-55.

${ }^{49}$ Direito Constitucional. 22. ed. São Paulo: Atlas, p. 259. 
A análise que se segue procura constatar os elementos da autonomia do Estado-membro na evolução do modelo federativo brasileiro, enfatizando a capacidade de auto-organização mediante poder constituinte do Estado-membro e elaboração do seu ordenamento jurídico sob o influxo da fonte mesma de suas limitações, a Constituição Federal.

\subsubsection{Estrutura, composição e competências previstas nas Constituições Estaduais de 1891. A reforma constitucional de 1926}

O auge da autonomia dos Estados federados transcorreu sob a égide da Constituição de 1891, que relacionou parcimoniosamente as competências privativas da União (art. 34), atribuindo aos Estados, “em geral, todo e qualquer outro poder ou direito, que lhes não for negado por cláusula expressa ou implicitamente contida nas cláusulas expressas da Constituição" (art. 65, § $2^{\circ}$ ).

Alguns Estados até exorbitaram do seu papel na Federação brasileira declarando-se soberanos (Bahia, Goiás, Mato Grosso e Piauí), autônomo e soberano (Paraná) e independente e soberano (Rio de Janeiro).

A Constituição Federal de 1891 preconizava que "cada Estado reger-se-á pela Constituição e pelas leis que adotar, respeitados os princípios constitucionais da União” (art. 63). Raul Machado Horta salienta que “a reduzida eficácia da limitação constitucional federal à autonomia do Estado-membro decorreu, especialmente, da indeterminação dos princípios constitucionais da União". 50 Com efeito, interpretação abalizada de João Barbalho, à época, sobre o artigo 63, pendia para a autonomia dos Estados-membros:

\footnotetext{
"Respeitados os princípios constitucionais da União, diz o artigo e não 'respeitada a Constituição Federal'; e isto indica que as Constituições dos Estados não estão obrigadas a segui-la inteiramente à risca, a modelarem-se completamente por ela, sem divergir em alguns pontos, contanto que não sejam fundamentais. E bem o compreenderam eles no organizarem seus governos apartando-se em alguma cousa do modelo federal." 51
}

\footnotetext{
50 A autonomia do Estado-membro no Direito Constitucional Brasileiro. Belo Horizonte: Estabelecimentos Gráficos Santa Maria, 1964, p. 86.

51 Constituição Federal Brasileira (1891).Ed. fac-similar. Brasília: Senado Federal, Conselho Editorial, 2002. p. 267.
} 
Sob essa moldura de repartição de competências delineada pela Constituição Federal, as Constituições estaduais, em regra, enumeraram ao Executivo atribuições consentâneas com funções a ele apropriadas, não o consagrando desmesuradamente; nesse diapasão também, não se descuidou o constituinte estadual das atribuições do Poder Legislativo. Exceção a esse modelo foi a Constituição do Rio Grande do Sul, também conhecida como Constituição castilhista, em referência a Júlio de Castilhos, positivista, e seu mais influente elaborador. Ela outorgou ao Poder Legislativo exíguas competências taxativamente enumeradas (arts. 46-48 ), mais precisamente 19 atribuições, 15 das quais "exprimiam, materialmente, competência financeira e orçamentária", merecendo de Raul Machado Horta constatação de que "o órgão legislativo fazia jus ao título de Assembléia orçamentária”. ${ }^{52}$ E dessas parcas competências a Assembléia de Representantes estava proibida de se afastar. Sobre essa singular repartição, considerada por Castro Nunes uma anomalia, enfatiza-se o mitigado papel reservado ao Poder Legislativo rio-grandense-do-sul:

"Mutilado em suas atribuições, sem atenção ao regimen de poderes separados que é da essência das instituições democrático-republicanas, o poder legislativo do Rio Grande do Sul é limitado à função orçamentária, à matéria tributária, à apuração da eleição do presidente, à fixação do subsídio presidencial e parlamentar, à autorização para empréstimos e operações de crédito e ao processo do impeachment." ${ }^{, 53}$

Sob outra perspectiva, a da valorização do Poder Legislativo mediante ampliação de suas competências, as constituições da Bahia e de Minas Gerais procuraram enumerar extensamente poderes reservados ao Legislativo; a baiana, e.g., estabelecia:

"Das atribuições da Assembléia Geral

Art. 36 - Compete à Assembléia Geral fazer leis, interpretá-las, suspendêlas e revogá-las; e, particularmente:

$\S 1^{\circ}$ - Orçar a receita e fixar a despesa anual do Estado e aprovar as contas da receita e despesa do exercício financeiro anterior.

$\S 2^{\circ}$ - Autorizar o Poder Executivo a contrair empréstimos e a fazer outras operações de crédito, fixando o máximo dos compromissos anuais que tenham de pesar sobre o Estado, de sorte que não excedam à quinta parte de suas rendas.

$\S 3^{\circ}$ - Legislar sobre a dívida pública e estabelecer os meios de satisfazer seu pagamento.

52 A autonomia do Estado-membro no Direito Constitucional Brasileiro. Belo Horizonte: Estabelecimentos Gráficos Santa Maria, 1964, p. 101.

${ }^{53}$ NUNES, José de Castro. As Constituições Estaduaes do Brasil. Rio de Janeiro: Edit. Leite Ribeiro, 1922, t. 1, p. 68. 
$\S 4^{\circ}$ - Regular a arrecadação e a distribuição das rendas do Estado, estabelecendo as contribuições, taxas e impostos necessários, nos limites prescritos pela Constituição Federal.

$\S 5^{\circ}$ - Fixar, anualmente, a força pública e a sua despesa.

$\S 6^{\circ}$ - Regular a administração dos bens do Estado e providenciar sobre a sua aquisição e alienação.

$\S 7^{\circ}$ - Legislar sobre o ensino primário, secundário e superior, especialmente sobre o ensino técnico e profissional, criando escolas práticas de agricultura nos centros agrícolas do Estado, instituições de ensino industrial e artístico e uma universidade na Capital.

$\S 8^{\circ}$ - Legislar sobre a organização municipal, de acordo com o art. 68 da Constituição Federal.

$\S 9^{\circ}$ - Legislar sobre a organização judiciária e processual.

$\S 10$ - Decretar a divisão civil, judiciária e eleitoral do Estado.

$\S 11$ - Mudar a capital do Estado, quando assim convier à sua segurança e interesse.

$\S 12$ - Autorizar o Poder Executivo a entabolar com outros Estados ajustes e negociações, sem caráter político, dependentes de ulterior aprovação da Assembléia.

$\S 13$ - Criar e suprimir empregos públicos e fixar-lhes as atribuições e vencimentos.

$\S 14$ - Deliberar sobre a anexação de território de outro Estado.

$\S 15$ - Regular as condições e o processo da eleição para os cargos do Estado e dos municípios, de acordo com os princípios adotados na presente Constituição.

$\S 16$ - Organizar a milícia do Estado, aproveitando a atual Guarda Nacional e estabelecendo os preceitos disciplinares a que ficará sujeita.

$\S 17$ - Legislar sobre comércio, imigração, colonização, indústrias e agricultura, nos limites traçados pela Constituição Federal.

$\S 18$ - Legislar sobre as obras públicas, estradas, ferrovias, canais e sobre navegação de rios que não estejam subordinados à administração federal.

$\S 19$ - Legislar sobre a desapropriação por utilidade do Estado, ou municipal, determinando os casos e a forma por que deverá ter lugar. extractivas.

$\S 20$ - Legislar sobre terras públicas, mineração e indústrias

$\S 21$ - Legislar sobre economia penitenciária, casas de prisão com trabalho e de correção.

$\S 22$ - Legislar sobre a assistência pública, casas de caridade e distribuição de socorros.

$\S 23$ - Organizar os códigos rural e florestal.

$\S 24$ - Legislar sobre organização do trabalho, atendendo à idade e ao sexo dos operários.

$\S 25$ - Legislar sobre a higiene pública e particular.

$\S 26$ - Reclamar a intervenção da União, no caso dos arts. 50 e 60 da Constituição Federal.

$\S 27$ - Decretar leis que tornem efetiva a responsabilidade dos funcionários que tenham a seu cargo a arrecadação das rendas públicas do Estado e do município.

$\S 28$ - Legislar sobre o estabelecimento do montepio obrigatório em benefício dos funcionários do Estado e suas famílias. 
$\S 29$ - Decretar todas as leis e resoluções necessárias ao exercício dos poderes que a Constituição confere ao governo do Estado.

$\S 30$ - Legislar sobre instituições de crédito real e agrícola e sobre a mobilização do solo.

$\S 31$ - Legislar sobre quaisquer outros objetivos de interesse para o Estado, em todos os casos não exclusivamente reservados ao poder federal ou municipal.

$\S 32$ - Proclamar o Governador e resolver sobre a renúncia do seu cargo.

$\S 33$ - Comutar e perdoar as penas impostas aos funcionários públicos do Estado, nos crimes de responsabilidade.

$\S 34$ - Marcar o subsídio dos Deputados e Senadores e os vencimentos do Governador do Estado, não podendo estes últimos serem alterados pelas legislaturas compreendidas no seu período administrativo.

$\S 35$ - Conceder ao Governador licença, por tempo determinado, para se ausentar do Estado.

$\S 36$ - Ceder aos municípios os edifícios ou propriedades do Estado que, sob solicitação dos conselhos, se reconheça lhes serem de utilidade, uma vez que não sejam necessários ao serviço do Estado.

$\S 37$ - Anular as posturas e decisões dos conselhos municipais, nos caos do art. 114 e seus $\$ \S .{ }^{54}$

$\S 38$ - Prorrogar o tempo das sessões até quando julgar conveniente ao bom desempenho de suas funções. União."

$\S 39$ - Velar pela guarda da Constituição e das leis do Estado e da

No federalismo dual de então, os Estados, ao se organizarem, deveriam assegurar "a autonomia dos Municípios em tudo quanto respeitasse ao seu peculiar interesse" (art. 68).

O constituinte estadual do Rio Grande do Sul (arts. 62-70) preferiu o sistema de cartas próprias ou leis orgânicas próprias para cada um de seus Municípios, enquanto os demais Estados adotaram o sistema de uma lei orgânica estadual para todos os seus respectivos Municípios, conservando os Poderes Legislativos destes Estados, à evidência, plena competência para legislar sobre relevante matéria.

\footnotetext{
54 “Art. 114 - As posturas e as decisões dos conselhos municipais poderão ser anuladas pela Assembléia Geral nos casos seguintes:

$\S 1^{\circ}$ - Quando forem contrárias às leis do Estado e federais.

$\S 2^{\circ}$ - Quando forem ofensivas dos direitos de outros municípios.

$\S 3^{\circ}$ - Quando forem manifestamente gravosas em matéria de impostos, havendo representação assinada por cem munícipes contribuintes.

Parágrafo único - Na ausência da Assembléia Geral, o Governador poderá suspender tais posturas e decisões; mas, desde que aquela se reúna, dar-lhe-á comunicação do ocorrido para que resolva definitivamente."
} 
Fortalecendo os Conselhos Municipais, em detrimento, contudo, do Poder Legislativo estadual, a Constituição do Rio Grande do Sul podia ser reformada por iniciativa do Presidente do Estado ou mediante petição da maioria dos Conselhos Municipais (art. 76). Quando a proposta de reforma da Constituição fosse de iniciativa do Presidente, competiria aos Conselhos Municipais, dentro de três meses, por maioria, aprová-la. Sendo de iniciativa da maioria dos Conselhos, se, decorridos três meses da publicação da proposta de reforma, "aquela maioria mantivesse o seu pedido", ao Presidente competiria promulgar a reforma constitucional. Do processo de "reforma da Constituição" (título V) o Poder Legislativo estadual não tinha qualquer participação.

Das razões de convencimento para promulgar ou vetar um projeto de lei, no processo legislativo estadual rio-grandense-do-sul, participava também "qualquer cidadão habitante do Estado", que podia oferecer, dentro de 3 meses, emendas ou observações sobre o projeto aprovado pelo Legislativo. Remetidas ao Presidente do Estado pelos respectivos intendentes dos Municípios, as emendas e as observações elaboradas pelos cidadãos poderiam, ou não, ser levadas em conta pelo Presidente, que as julgava procedentes conforme seu próprio juízo. Caso o Presidente não acatasse as emendas e observações feitas pelos cidadãos e mantivesse inalterado o projeto aprovado pelo Legislativo, promulgando-o, mesmo assim, a matéria aprovada pelo Poder Legislativo poderia ser revogada, "se a maioria dos Conselhos representasse contra ela ao Presidente" (art. 32).

A despeito de no processo legislativo federal, o veto previsto na Constituição Federal de 1891, até a sua única reforma, ocorrida em 1926, só poder ser total, por inconstitucionalidade ou por contrariedade aos interesses da Nação (art. 37), as Constituições Estaduais da Bahia (art. 41), Ceará (art. 33), Maranhão (art. 27, § $2^{\circ}$ ) e Pará (art. 29) já adotavam o veto parcial para proposições orçamentárias, e a Constituição de Minas Gerais ampliava o veto parcial, permitindo-o igualmente para outras matérias, além da orçamentária (art. $38, \S 2^{\circ}$ ). Sem se afeiçoar ao processo legislativo federal, que somente o adotará em 1926, o veto parcial foi disciplinado por ordenamentos constitucionais estaduais.

Às Assembléias dos Estados conferia-se competência para deflagrar o processo de 'reforma' da Constituição Federal (art. 90), desde que dois terços dos 
Estados, no decurso de um ano e mediante deliberação de maioria de votos de cada Assembléia, fizesse a solicitação da proposta de emenda constitucional.

Impende anotar, como preceito comum previsto nas Constituições Estaduais, a competência de as Assembléias Legislativas, como guardiãs do ordenamento constitucional, poderem anular posturas e resoluções municipais contrárias às Constituições Federal e Estadual. Durante o recesso das Assembléias, competia ao Governador suspender a eficácia dessas normas municipais, até definitiva deliberação do Poder Legislativo estadual. A Constituição do Rio Grande do Sul, no entanto, outorgava ao Presidente do Estado, "Chefe Supremo do governo e da administração" (art. 20, caput), competência para, independentemente de qualquer pronunciamento da Assembléia dos Representantes, "declarar sem efeito as resoluções ou atos das autoridades municipais, quando infringirem leis federais ou do Estado" (art. 20, § 18).

\section{Referentemente à estrutura do Poder Legislativo dos Estados Federados,} malgrado eles não constituíssem nem constituam federação de municípios, muito menos houvesse preceito na Constituição Federal para que fosse instituído Senado estadual, o fato é que sete Estados (Alagoas, Bahia, Goiás, Minas Gerais, Pará, Pernambuco e São Paulo) previram em suas Constituições uma "Câmara Alta", adotando-se também estrutura bicameral em Legislativo estadual.

\section{O número de Deputados estaduais, fixado pelas Constituições dos}

Estados, ficava entre 18 (Mato Grosso, art. 6º e 60 membros (São Paulo, art. 18). As constituições também fixavam o mandato parlamentar, em 2 anos (Bahia, art. $9^{\circ}, \S 1^{\text {o}}$; Mato Grosso, art. $6^{\circ}, \S 1^{\circ}$; Paraná, art. $6^{\circ}$ ), 4 (Ceará, art. $8^{\circ}$; Goiás, art. 53, § 2; Minas Gerais, art. 24; Paraíba, art. $6^{\circ}$; Piauí, art. $7^{\circ}, \S 2^{\circ}$; Rio Grande do Sul, art. 37, § $2^{\circ}$ ) ou em 3 anos nos demais Estados. O mandato dos Senadores estaduais na Bahia e em Pernambuco era de 6 anos; de 8 anos em Goiás e Minas Gerais; e de 9 anos em Alagoas, Pará e São Paulo. Como regra, nos Estados onde havia Senado, o número de seus membros correspondia à metade dos Deputados estaduais. ${ }^{55}$

\footnotetext{
${ }^{55}$ Informa Castro Nunes: "Em Pernambuco e Alagoas, 15 senadores e 30 deputados; em Goyaz, 12 senadores e 24 deputados; na Bahia, 21 senadores e 42 deputados. Em São Paulo os deputados são em número correspondente a 1 por 70.000 habitantes, até ao máximo de 60; os senadores na base de 1/140, não podem exceder de 30. Em Minas Geraes, cada deputado representa 70.000 habitantes, sendo o máximo constitucionalmente fixado em 48; e cada senador corresponde a 140.000 habitantes, fixado em 24 o limite máximo. No Pará correspondem a 28 deputados, senadores em numero de 18." As Constituições Estaduaes do Brasil. Rio de Janeiro: Edit. Leite Ribeiro, 1922, t. 1, p. 62.
} 
A designação dos Legislativos variava nas vinte Constituições estaduais: Assembléia (Sergipe, art. $6^{\circ}$ ); Assembléia Legislativa (Amazonas, art. 6º ; Ceará, art.

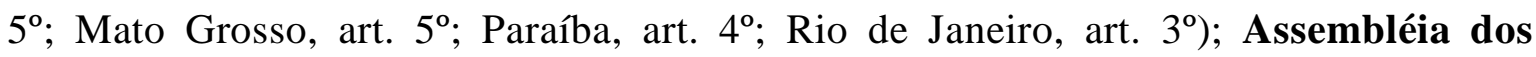
Representantes (Rio Grande do Sul, arts. $6^{\circ}$ e 35); Câmara de Deputados (Piauí, art. $6^{\circ}$ ); Assembléia Geral, composta por Câmara dos Deputados e Senado (Bahia, art. $6^{\circ}$ ); Congresso, composto por Câmara dos Deputados e Senado (Alagoas, art. 3º; Pará, art. 5; Goiás, art. 52; Pernambuco [Congresso Legislativo], art. 4º ${ }^{\mathrm{o}}$ Minas Gerais, art. $9^{\circ}$; São Paulo, art. $5^{\circ}$ ). Equivocadamente utilizava-se, igualmente, o termo Congresso para Legislativos constituídos por somente uma Câmara legislativa (Espírito Santo, art. 29; Maranhão, art. 6º Paraná [Congresso Legislativo do Estado], art. 5º Rio Grande do Norte [Congresso Legislativo], parágrafo único do art. $5^{\circ}$ ). Ocorrendo, ainda, designação de Congresso Representativo (Santa Catarina, art. $8^{\circ}$ ) para um Legislativo estadual unicameral.

Exceto em São Paulo, com funcionamento durante 4 meses, e Rio Grande do Norte, durante 1 mês, as sessões legislativas anuais do Poder Legislativo estadual duravam de 2 a 3 meses, iniciando-se em variadas datas:

a) Alagoas: em 21 de abril, durante 3 meses (arts. $6^{\circ}$ e $7^{\circ}$ );

b) Amazonas: a partir de 10 de julho, durante 3 meses (art. $8^{\circ}$ );

c) Bahia: no dia 7 de abril, com duração de 3 meses (art. $9^{\circ}$ );

d) Ceará: a partir de $1^{\circ}$ de julho, durante 2 meses (arts. $7^{\circ}$ e $8^{\circ}$ );

e) Espírito Santo: no dia 7 de setembro, com duração de 2 meses (art. 30);

f) Goiás: em 13 de maio, durante 2 meses (art. 53);

g) Mato Grosso: 13 de maio, durante 2 meses (art. $6^{\circ}$ );

h) Maranhão: de 5 de fevereiro a 5 de abril (art. $6^{\circ}$ );

i) Minas Gerais: 21 de abril, durante 3 meses (art. 11);

j) Pará: data fixada em lei ordinária, durante dois meses (art. $7^{\circ}$ );

k) Paraíba: dois meses "contados do dia de sua instalação" (art. 6º;

1) Paraná: em $1^{\circ}$ de outubro, durante 2 meses (art. $8^{\circ}$ );

m) Pernambuco: em 6 de março, durante 3 meses (arts. $7^{\circ}$ e 12);

n) Piauí: a partir de $1^{\circ}$ de junho, durante 60 dias (art. $7^{\circ}$ );

o) Rio de Janeiro: em $1^{\circ}$ de agosto, durante 3 meses (art. $5^{\circ}$ );

p) Rio Grande do Norte: em $1^{\circ}$ de novembro, durante 30 dias (art. $7^{\circ}$ );

q) Rio Grande do Sul: em 20 de setembro, durante 2 meses (art. 37); 
r) Santa Catarina: em 22 de julho, durante 2 meses (art. 10);

s) São Paulo: em 14 de julho, durante 4 meses (art. $6^{\circ}$ ); e

t) Sergipe: no dia 7 de setembro, durante 2 meses (art. $6^{\circ}, \S \S 2^{\circ}$ e $3^{\circ}$ ).

Anote-se como mais uma amostra da hipertrofia do Poder Executivo em relação ao Legislativo no Rio Grande do Sul, que ao Presidente do Estado, "Chefe Supremo do governo" (art. 20, caput) competia, além de convocar extraordinariamente a Assembléia dos Representantes, "prorrogar as suas sessões, quando o exigir o bem público, expondo sempre os motivos da convocação e prorrogação" (art. 20, $\S 5^{\circ}$ ).

Em 1926 houve a única reforma à Constituição de 1891. Vários fatores são apontados por estudiosos e historiadores para que houvesse solapamento da originária autonomia conferida aos Estados federados ${ }^{56}$ : fortalecimento de estruturas políticas oligárquicas nos Estados; sistema eleitoral possibilitando resultados fraudulentos nas eleições, tendo havido em Estados e Municípios dualidade, duplicata de Assembléias Legislativas e de Presidentes ou Governadores do Estado ${ }^{57}$; intervenções federais exacerbadas, políticas, sem fundamentação jurídica; enfraquecimento da autonomia municipal; inobservância pelos Governos estaduais de decisões do Poder Judiciário quando consideradas inconstitucionais matérias de natureza tributária designadamente.

Fortalecendo a centralização do poder federal, princípios constitucionais foram enumerados pela reforma constitucional de 1926, os quais, (art. $6^{\circ}$, II), se não observados, ensejariam a intervenção federal nos Estados: a) a forma republicana; b) o regime representativo; c) o governo presidencial; d) a independência e harmonia dos Poderes; e) a temporalidade das funções eletivas e a responsabilidade dos funcionários; f) a autonomia dos municípios; g) a capacidade para ser eleitor ou elegível nos termos

\footnotetext{
${ }^{56}$ CARVAlHO, José Murilo de. Cidadania no Brasil: o longo caminho. 3. ed. Rio de Janeiro: Civilização Brasileira, 2002, p. 31-38. LEAL, Vitor Nunes. Coronelismo, enxada e voto: o município $e$ o regime representativo no Brasil. 5. ed. São Paulo: Alfa-Ômega, 1975, p. 19-57. LEWANDOWSKI, Enrique Ricardo. Pressupostos materiais e formais da intervenção federal no Brasil. São Paulo: Ed. Revista dos Tribunais, 1994, p. 59-72. TRIGUEIRO, Oswaldo. Direito Constitucional Estadual. Rio de Janeiro: Forense, 1980, p. 28-32; 107-111. HORTA, Raul Machado. A autonomia do Estado-membro no Direito Constitucional brasileiro. Belo Horizonte: Gráf. Santa Maria, 1964, p.132-166. ZIMMERMANN, Augusto. Teoria Geral do federalismo democrático. 2. ed. Rio de Janeiro: Lumen Juris, 2005, p. 300-313. ROCHA, Cármen Lúcia Antunes. República e Federação no Brasil. Belo Horizonte: Del Rey, 1996, p. 214-226. NUNES, Castro. As Constituições estaduais do Brasil. Rio de Janeiro: Ed. Leite Ribeiro, 1922, t. 1. p. 79-178.

${ }^{57}$ Ver justificativas e conteúdo do Projeto n. 43, de 1894, de autoria dos Senadores João Barbalho, Almeida Barreto e outros. V. Projeto n. 156, de 1894, de autoria do Deputado Aristides Milton. Cf. também Documentos Parlamentares - Intervenção nos Estados. Rio de Janeiro: Tip. do Jornal do Comércio, 1917, 16 vol.
} 
da Constituição; h) um regime eleitoral que permita a representação das minorias; i) a inamovibilidade e vitaliciedade dos magistrados e a irredutibilidade dos seus vencimentos; j) os direitos políticos e individuais assegurados pela Constituição; k) a não-reeleição dos Presidentes e Governadores; 1) a possibilidade de reforma constitucional e a competência do Poder Legislativo para decretá-la. A explicitação de alguns desses princípios constitucionais -designadamente a representação das minorias, a proibição de reeleição de Presidente ou Governador de Estado e a previsão de reforma constitucional por intermédio do Legislativo Estadual- decorreram do Acordo de Pedras Altas, firmado em 14 de dezembro de 1923, entre Assis Brasil (candidato a Governador derrotado) e Borges de Medeiros (candidato reeleito). Nesse pacto, que pacificou o Rio Grande do Sul após cerca de onze meses de sangrenta luta entre maragatos e chimangos, firmaram-se, igualmente, alterações que a Constituição do Rio Grande do Sul sofreria: proibição de reeleição do Presidente do Estado; eleição de Vice-Presidente; legislação federal delineando as eleições estaduais e municipais.

\subsubsection{Dissolução das Casas Legislativas em 1930}

A autonomia dos Estados federados iniciou seu declínio sob a égide da própria Constituição de 1891, por intermédio da reforma constitucional de 1926, como já frisado supra, e aprofundou-se ainda mais com a revolução armada de 1930, que durou 3 semanas ( 2 a 24 de outubro), e tivera raízes em fatores acima expostos também, vez que o aprimoramento do sistema eleitoral brasileiro passou a fazer parte da ordem do dia jurídico-política, tantas as deformações constatadas nos processos eleitorais transcorridos no período denominado de República Velha (1891-1930).

Nesse período houvera manifesta deturpação da liberdade de escolha dos representantes, efetivada em eleições fraudulentas decorrentes da ação de oligarcas "coronéis" designadamente, impondo o "voto de cabresto" ao seu "curral eleitoral". 58 Títulos de eleitores falsificados, votos e apurações fraudadas. ${ }^{59}$ A sistemática de verificação dos poderes, a cargo das Casas Legislativas, não se contrapunha a essas irregularidades; ao contrário, servia à "máquina majoritária [que] assegurava a sua perpetuação, manipulando o instituto da verificação dos poderes, ${ }^{60}$ decapitando os

\footnotetext{
${ }^{58}$ LEAL, Vitor Nunes. Coronelismo, enxada e voto: o município e o regime representativo no Brasil. 5. ed. São Paulo: Alfa-Ômega, 1975. p. 19-57.

59 CARVAlho, José Murilo de. Cidadania no Brasil: o longo caminho. 3. ed. Rio de Janeiro: Civilização Brasileira, 2002. p. 31-38.

60 Aurelino Leal discorre, com minúcias (p. 256-265), sobre o processo da "verificação e reconhecimento de poderes", à luz da Constituição de 1891. E para ele "seria uma temeridade
} 
mandatos oposicionistas que conseguiam vencer as resistências na fase eleitoral".61 Sobre esse sistema eleitoral, Assis Brasil fazia a seguinte resenha:"Ninguém tem certeza de ser alistado eleitor; ninguém tem certeza de votar, se porventura foi alistado; ninguém tem certeza de que lhe contem o voto, se porventura votou; ninguém tem certeza de que esse voto, mesmo depois de contado, seja respeitado na apuração da apuração, no chamado terceiro escrutínio.",62

Vitoriosa a Revolução de 1930, uma Junta Provisória ${ }^{63}$ assumiu o Governo por uma semana; logo depois, como Delegado da Revolução, Getúlio Dornelles Vargas assumiu o poder em 03 de novembro de 1930 e, no dia 11 deste mês, editou o Decreto n. 19.398. Malgrado mantivesse em vigor a Constituição Federal, as Constituições Estaduais e os atos e posturas municipais, todos, no entanto, ficavam adstritos às normas daquele Decreto que, ao que interessa frisar para este estudo, dissolveu o Congresso Nacional e todas as Casas Legislativas dos Estados e dos Municípios, fazendo tabula rasa da autonomia dos Estados-membros.

Até então não expressamente prevista pela Constituição de 1891, a figura do Interventor Federal foi criada pelo art. 11 do Decreto 19.398, de 11 de novembro de 1930. Investia-se o Interventor Federal das funções atinentes às dos Poderes Legislativo e Executivo estadual, incumbindo-se-lhe a execução do decidido pelo Governo Provisório. Em 29 de agosto de 1931, no entanto, foram instituídos pelo Decreto n. 20.348 os Conselhos Consultivos nos Estados e nos Municípios. Observa Raul Machado Horta:

"a autoridade do Interventor Federal, que o Decreto n. 19.398 submetia
unicamente ao contraste hierárquico do Chefe do Governo Provisório,
viu-se posteriormente contida por órgão estadual, de natureza
consultiva, cujos membros eram nomeados pelo Chefe do Governo

adoptar, em qualquer tempo, o alvitre de conferir a esta ou áquella autoridade judiciária competencia para resolver sobre verificação de poderes. N'um regimen como o nosso, em que o Judiciário é o supremo contrasteador da Constituição, investil-o de tal attribuição seria leval-o da arena da justiça para o circulo quase sempre confuso e não raro anarchico dos partidos. Tal remédio augmentaria o mal, em vez de cural-o. Será melhor esperar da cultura cívica do povo e da moralidade do parlamento o indispensável correctivo". In Teoria e prática da Constituição Federal brasileira. Rio de Janeiro: Briguiet, 1925. p. 255.

${ }^{61}$ RIBEIRO, Fávila. Direito eleitoral. 3. ed. Rio de Janeiro: Forense, 1988. p. 94.

${ }^{62}$ ASSIS BRASIL, Joaquim Francisco de. A democracia representativa na República. Brasília: Senado Federal, 1998. p. 312.

63 "Composta pelo General maranhense Augusto Tasso Fragoso, que a chefiava, pelo General gaúcho João de Deus Menna Barreto e pelo Almirante carioca José Isaías de Noronha." Cf. MORAES, Alexandre de. Presidencialismo. São Paulo: Atlas, 2004, p. 112. 
Provisório e ao qual se confiou o controle dos atos do Interventor, seja pelo exame desses atos, nos recursos contra eles interpostos, seja pela necessária audiência prévia do Conselho Consultivo sobre atos fundamentais da administração estadual." 64

Neste período, não há falar em Poder Legislativo estadual, eis que dissolvidas as Casas Legislativas, ficando ao Interventor Federal e ao Conselho Consultivo a função normativa no âmbito estadual.

Com o Poder Legislativo nacional, estadual e o municipal eclipsados, o processo de reconstitucionalização foi sendo postergado pelo Governo Provisório. Em 1932 São Paulo pegou em armas em defesa da convocação de uma Assembléia Nacional Constituinte. Mesmo derrotada, a Revolução Constitucionalista paulista obteve seu desiderato com a instalação e trabalhos da Assembléia Nacional Constituinte de $1933-34{ }^{65}$

\subsubsection{O Poder Legislativo dos Estados-membros no modelo federativo da Constituição de 1934}

A Constituição Federal de 1934 concedia aos Estados competência privativa para "exercer, em geral, todo e qualquer poder ou direito que lhes não for negado explícita ou implicitamente por cláusula expressa dessa Constituição" (art. $7^{\circ}$, IV). Todavia, a par de conferir ao constituinte estadual autonomia para, por exemplo, estender aos parlamentares estaduais o instituto da inviolabilidade, uniformizou a designação do Poder Legislativo Estadual, denominando-o Assembléia Legislativa e vedando a fixação de mandatos aos Deputados estaduais superiores aos dos Deputados federais. Por designar o Legislativo Estadual como Assembléia Legislativa todas as vezes que a ele o constituinte federal tivera que se referir (Arts. 14; 112, 2 e 3; $175, \S 4^{\circ} ; 178, \S \S 1^{\circ}$ e $2^{\circ} ; 181 ;$ art. $3^{\circ}, \S 1^{\circ}$, do ADCT), concluiu-se que a Constituição Federal vedara, implicitamente, o bicameralismo ${ }^{66}$; todavia, de forma expressa, somente a Comissão do Itamaraty, autora do anteprojeto de Constituição de 1934, o tivera feito (“Art; 81 - Os Estados organizar-se-ão de acordo com a Constituição e as leis que adotarem, respeitados os seguintes princípios constitucionais: ... d) Poder Legislativo unicameral;").

\footnotetext{
${ }^{64}$ A autonomia do Estado-membro..., p. 160-1.

65 CARVAlho, José Murilo de. Cidadania no Brasil: o longo caminho. 3. ed. Rio de Janeiro: Civilização Brasileira, 2002, p. 101. REALE, Miguel. Espírito da Revolução Constitucionalista. In $O$ Estado de S. Paulo, 27 jul. 2004, p. A-2.

${ }^{66}$ TRIGUEIRO, Oswaldo. Direito Constitucional Estadual. Rio de Janeiro: Forense, 1980, p. 132.
} 
A autonomia do Estado-membro ficou parametrizada (os dicionários não relacionam tal verbo) pelos princípios constitucionais enumerados: a) forma republicana representativa; b) independência e coordenação dos poderes; c) temporariedade das funções eletivas, limitada aos mesmos prazos dos cargos federais correspondentes, e proibida a reeleição de Governadores e Prefeitos para o período imediato; d) autonomia dos Municípios; e) garantias do Poder Judiciário e do Ministério Público locais; f) prestação de contas da administração; g) possibilidade de reforma constitucional e competência do Poder Legislativo para decretá-la; e h) representação das profissões $\left(\operatorname{art.} 7^{\circ}, \mathrm{I}\right)$.

No sistema de repartição de competências adotado pelo constituinte federal de 1933-34, aliás, influenciado pelo sistema da Lei Fundamental da Alemanha, conhecida como Constituição de Weimar, pois discutida e votada nesta cidade da Saxônia, em 1919, alargou-se a competência concorrente entre União e o Estadomembro, a deste em caráter supletivo ou complementar (art. $7^{\circ}$, II). No entanto, essa compensação de competência ao Estado-membro não conseguia conter a exuberância das matérias de competência da União expressamente enumeradas (art. $5^{\circ}$ ), em detrimento das remanescentes, conferida aos Estados-membros. Essa sistemática de repartição de competências legislativas dimensionada pelo constituinte federal de 193334 iniciou processo de esvaziamento das competências legislativas dos Estadosmembros e, nestes, do Poder Legislativo estadual designadamente.

A Constituição Federal de 1934, conclui Raul Machado Horta, "elaborada sob o signo do intervencionismo no domínio econômico e social, preferiu técnica de repartição de competências favorável à União e à plenitude dos poderes federais, o que provocou correlativo amortecimento da autonomia do Estado, afetada duplamente. Em primeiro lugar, pela transferência de matéria anteriormente colocada na sua área legislativa e, em segundo, pela limitação do campo normativo residual em virtude da extensão dos poderes enumerados", 67 (Negritou-se.)

O constituinte estadual de 1935, como se viu, além de adotar a denominação de Assembléia Legislativa, igualmente deveria prever, em sua composição, representantes de profissões. Foi o que fez.

\footnotetext{
${ }^{67}$ A autonomia do Estado..., p. 182-3.
} 
Ao que se propõe este estudo, sublinhe-se quanto ao processo legislativo estadual, a Constituição do Estado de Minas Gerais, e.g., permitia a iniciativa popular mediante subscrição de, no mínimo, dez mil eleitores, bem como a iniciativa de projetos de lei por proposta de um quarto dos Municípios do Estado. Esses titulares de iniciativa legislativa não estavam contemplados no modelo federal de feitura de leis.

\subsubsection{Estado Novo e ausência de democracia representativa}

Por um Golpe de Estado perpetrado em 10 de novembro de 1937 pelo Presidente da República Getúlio Dornelles Vargas, ao povo brasileiro foi outorgada uma Carta. Nominalmente os Legislativos Estaduais estavam previstos no texto constitucional, mas, de fato, não existiram durante o Estado Novo.

Estados e Municípios tiveram suas organizações delineadas pelo Decreto-lei n. 1.202, de 8 de abril de 1939, que declarava órgãos da administração do Estado o Interventor, ou Governador e o Departamento Administrativo, discriminando suas funções. Esta norma foi modificada pelos Decretos-leis n. 5.511, de 21 de maio de 1943 e 7.518 , de 3 de maio de 1945.

Não há falar em Poder Legislativo estadual durante a vigência da Constituição de 1937, cujo plebiscito, previsto para ratificá-la (art. 178), jamais se realizou, bem como não houve eleições para mandatos eletivos. Inexistiu Estado federal, vigente Estado unitário descentralizado sob domínio intervencionista autoritário.

\subsubsection{Autonomia dos Estados-membros no modelo federativo da Constituição de 1946}

Muito embora a autonomia do Estado-membro tenha se constituído num dos “temas centrais da Constituinte de 1946 e sua restauração identificava uma preocupação comum" ${ }^{68}$, o arranjo final acentuou a tendência de centralização de poderes na órbita da União. Estatuiu-se a observância, pelos Estados, dos "princípios estabelecidos nesta Constituição". Manteve-se a enumeração de princípios constitucionais a serem observados pelos Estados: a) forma republicana representativa; b) independência e harmonia dos poderes; c) temporariedade das funções eletivas, limitada a duração destas à das funções federais correspondentes; d) proibição de reeleição de governadores e prefeitos para o período imediato; e) autonomia municipal; f) prestação de contas da administração e g) garantias do Poder Judiciário (art. $7^{\circ}$, VII).

\footnotetext{
${ }^{68}$ Raul Machado Horta, ob. cit. p. 209.
} 
Aprofundou-se o rol de matérias de competência da União para legislar (art. $5^{\circ}$, inciso $\mathrm{XV}$, alíneas ' $a$ ' a ' $r$ '). E concedeu-se restaurar a sistemática de legislação concorrente (art. $6^{\circ}$ ) inaugurada em 1934, não subordinando, todavia, a competência legislativa supletiva ou complementar estadual à legislação federal. Acerca do assunto esclarece Raul Machado Horta: “A legislação estadual complementar ou supletiva preencherá o branco da legislação federal, para afeiçoamento às peculiaridades locais, suprimento de deficiências ou de lacunas. A legislação concorrente impede que a legislação estadual transponha esse quadro de competência, cujo corretivo surgirá no primado da lei federal, mesmo quando não expressamente enunciado." 69

Apesar dos engenhosos dispositivos de frenação impostos ao constituinte estadual, houve Constituições Estaduais que, em matéria de processo legislativo, não se vergaram incondicionalmente ao modelo federal. Cite-se a Constituição da Bahia que previa proposta de emenda constitucional estadual mediante iniciativa de 20 Câmaras Municipais (art. 26); a vigência de Emenda Constitucional poderia ser condicionada pela Assembléia Legislativa ao referendo popular (art. 26, $\S 5^{\circ}$ ). A Constituição do Rio Grande do Sul, igualmente, conferia a iniciativa de projeto de lei às Câmaras Municipais e ao conjunto de cinco mil eleitores (art. 56); concedia à Câmara Municipal competência para aprovar e modificar, por dois terços, a Lei Orgânica do Município (art. 154, II).

Registre-se que mais da metade das Assembléias Legislativas, manifestandose cada uma delas pela maioria de seus membros e no decurso de dois anos, poderia propor emenda à Constituição Federal (art. 217), bem assim a possibilidade de os cidadãos escolherem seus representantes mediante voto direto.

\subsubsection{Autonomia dos Estados-membros no modelo federativo da Constituição de 1967, com redação dada pela EC n. 1/69}

O Comando Supremo da Revolução de 31 de março de 1964, assim autointitulado, ao editar o Ato Institucional n ${ }^{\mathrm{o}}$ 1, em 9 de abril de 1964, explicava à Nação, em sua exposição de motivos: "a revolução vitoriosa se investe no exercício do Poder Constituinte. Este se manifesta pela eleição popular ou pela revolução. Esta é a forma mais expressiva e mais radical do Poder Constituinte. Assim, a revolução vitoriosa, como Poder Constituinte, se legitima por si mesma". Embora reafirmada pelos militares signatários do Ato como sendo a revolução a forma mais radical do poder constituinte,

\footnotetext{
${ }^{69}$ Idem, p. 223.
} 
paradoxalmente concediam: "para demonstrar que não pretendemos radicalizar o processo revolucionário, decidimos manter a Constituição de 1946”. Vigorava ainda uma Constituição, mantida pelos militares vitoriosos, que não deixaram de infligir à Nação o infausto esclarecimento de que "sem as limitações previstas na Constituição, os Comandantes-em-Chefe, que editam o presente Ato, poderão suspender os direitos políticos pelo prazo de 10 (dez) anos e cassar mandatos legislativos federais, estaduais e municipais, excluída a apreciação judicial desses atos”.

O Ato Institucional $\mathrm{n}^{\mathrm{o}}$ 2, de 27 de outubro de 1965, decretou em seu artigo 18: "Ficam extintos os atuais Partidos Políticos e cancelados os respectivos registros." Em 7 de dezembro de 1966, foi editado o Ato Institucional no 4, convocando o Congresso Nacional para se reunir extraordinariamente em exíguo período, de 12 de dezembro de 1966 a 24 de janeiro de 1967, com a finalidade de discutir, votar e promulgar uma nova Constituição, cujo projeto era, então, apresentado pelo Presidente da República. Obedecido o comando constitucional, no dia determinado foi promulgada a Constituição pelo Congresso.

Em 13 de dezembro de 1968 foi editado mais um ato de exceção, este agora escandalosamente antidemocrático, o Ato Institucional n. 5 (AI-5). Por ele o Presidente da República podia decretar o recesso do Legislativo, só retornando ao funcionamento quando convocado novamente pelo Presidente da República. Decretado o recesso parlamentar, ficava o Poder Executivo correspondente autorizado a legislar sobre todas as matérias (art. $2^{\circ}$ do AI-5). Com fundamento nesse ato de exceção, a Junta Militar, no exercício do Poder Executivo, fechou o Congresso e editou a Emenda Constitucional n. 1, de 17 de outubro de 1969, dando nova redação à Constituição de 1967. No âmbito do Poder Constituinte Estadual, o preâmbulo da Constituição do Estado de São Paulo merece ser transcrito para o fiel entendimento daquele imbróglio jurídico-constitucional estabelecido, se é que pode ser assim denominado sem apoucamento ao termo italiano:

“O GOVERNADOR DO ESTADO DE SÃO PAULO, no uso de suas atribuições, e considerando que, pela Emenda Constitucional n. 1, de 17 de outubro de 1969, foram introduzidas modificações em dispositivos da Constituição da República que, assim, passa a vigorar com nova redação a partir de 30 de outubro de 1969; CONSIDERANDO que o novo texto constitucional, em seu artigo 200, determina que as disposições dele constantes ficam incorporadas, no que couber, ao direito constitucional legislado dos Estados; CONSIDERANDO que a 
adaptação das disposições da Constituição do Estado de São Paulo, atingidas pelas normas constitucionais federais impõe necessariamente a alteração de outros dispositivos, para harmonizá-los com o sistema e os princípios da Constituição da República; CONSIDERANDO a conveniência de se proceder desde logo a essa adaptação, não só para facilitar o conhecimento e aplicação das novas normas constitucionais estaduais, como para permitir que elas tenham vigência simultânea com as da Constituição da República; CONSIDERANDO que a Assembléia Legislativa, por força do Ato Complementar n. 47, de 7 de fevereiro de 1969, se acha em recesso, durante o qual, na conformidade do $\S 1^{\circ}$ do artigo $2^{\circ}$ do Ato Institucional n. 5, de 13 de dezembro de 1968, o Governador está autorizado a legislar em todas as matérias; CONSIDERANDO que, no processo legislativo, se inclui a elaboração de emendas à Constituição, como se vê do artigo 49, inciso I, da Constituição da República, de 24 de janeiro de 1967, correspondente ao artigo 46, inciso I, da mesma Constituição emendada, e reproduzido no artigo 18, inciso I, da Constituição do Estado de São Paulo; CONSIDERANDO, finalmente, que, feitas as modificações mencionadas, todas em caráter de emenda, a Constituição poderá ser editada de acordo com o texto que adiante se publica; PROMULGA a seguinte Emenda n. 2, à Constituição do Estado de São Paulo, de 13 de maio de 1967:"

A Constituição de 1967, com a redação dada pela Emenda Constitucional n. 1/69, enumerou, à semelhança da fórmula utilizada pela Constituição de 1946, princípios de observância obrigatória pelos Estados-membros que, se descumpridos, poderiam ensejar intervenção federal nos Estados (art. 10, VII, alíneas ' $a$ ' a ' $g$ ') e, a esses princípios, dentre outros ainda (art. 13, caput), adicionou, expressamente, outros tantos que também deveriam ser observados (art. 13, incisos I a IX) na elaboração de suas Constituições.

Acerca da questão dos princípios a serem observados pelo Poder Constituinte Decorrente, Anna Cândida da Cunha Ferraz enfatiza: “A enumeração dos princípios que circunscrevem a ação do Poder Constituinte Decorrente não obedece a critérios técnicos, o que dificulta muitíssimo a compreensão dos princípios a serem respeitados pelo Constituinte Estadual. Não é de espantar, pois (observe-se a latere) que o Constituinte Estadual praticamente 'copia' a Constituição Federal, induzido, talvez, pelo temor de 'esquecer preceitos' ou quem sabe, pela dificuldade de distinguir quais os preceitos que devem ser copiados, dos que devem ser assimilados ou 
adaptados e quais os preceitos da Constituição Federal que não precisam ser necessariamente adotados pelos Estados". 70

Sublinhe-se que, dentre outros princípios estabelecidos na Constituição Federal, os Estados-membros deveriam observar o do processo legislativo federal (art. 13, III). Como se sabe, o processo legislativo federal fundamentava-se sobre as bases de um Legislativo bicameral e não havia, no preceito constitucional, qualquer menção à cláusula de adaptação, “onde couber", para a observância do processo legislativo estadual unicameral ao federal, carecendo de rigor esta determinação da Constituição Federal.

Aos Estados-membros determinou-se, ainda, que as disposições constantes na Constituição Federal ficavam incorporadas, no que coubesse, ao Direito Constitucional legislado dos Estados, proibindo-os de adotarem os decreto-leis e facultando-se-lhes a adoção do regime de leis delegadas (art. 200). Sobre o decreto-lei, Oswaldo Trigueiro, após imputar-lhe o condão de destoar do princípio da separação de poderes, afirma que é o que "mais contribui para degradar o Poder Legislativo, em um quadro de instituições nominalmente democráticas. Dessa capitis diminutio, entretanto, foram inexplicavelmente poupadas as Assembléias estaduais" ${ }^{, 71}$. Exceto Acre, Mato Grosso, Rio de Janeiro e São Paulo, as Constituições dos demais Estados-membros previram a possibilidade de adoção do regime de leis delegadas.

\subsubsection{Estrutura, composição e funcionamento das atuais Assembléias Legislativas}

O Poder Legislativo dos Estados-membros, previsto na Constituição Federal de 1988, possui estrutura unicameral, recebe a denominação de Assembléia Legislativa e é composto por Deputados Estaduais. Se se for argumentar que poderia ser bicameral a sua estrutura e que poderia receber designação outra que não fosse “Assembléia Legislativa”, ter-se-ia então que considerar como apenas nominais e despojadas de efetividade as disposições constitucionais previstas no: a) caput do art. 27: "O número de Deputados à Assembléia Legislativa corresponderá ...”; $b$ ) $§ 2^{\circ}$ do art. 27: “O subsídio dos Deputados Estaduais será fixado por Lei de iniciativa da Assembléia Legislativa ..."; $c$ ) $\S 3^{\circ}$ do art. 27: "Compete às Assembléias Legislativas dispor sobre seu regimento interno ...”; $d$ ) $\S 2^{\circ}$ do art. 28: "Os subsídios

\footnotetext{
${ }^{70}$ Poder Constituinte do Estado-membro. São Paulo: Ed. Rev. dosTribunais, 1979, p.158.

${ }^{71}$ Direito Constitucional Estadual. Rio de Janeiro: Forense, 1908, p. 148.
} 
do Governador, do Vice-Governador e dos Secretários de Estado serão fixados por lei de iniciativa da Assembléia Legislativa ..."; e) inciso IX do art. 29: "Proibições e incompatibilidades, no exercício da vereança, similares, no que couber, ao disposto nesta Constituição para os membros do Congresso Nacional e, na Constituição do respectivo Estado, para os membros da Assembléia Legislativa.”; $f$ ) $\S 1^{\circ}$ do art. 36: "O decreto de intervenção (...) será submetido à apreciação do Congresso Nacional ou da Assembléia Legislativa do Estado, no prazo de vinte de quatro horas."; g) $\S 2^{\circ}$ do art. 36: "Se não estiver funcionando o Congresso Nacional ou a Assembléia Legislativa, far-se-á convocação extraordinária ..."; h) § $3^{\circ}$ do art. 36: "Nos casos do art. 34, VI e VII, ou do art. 35, IV, dispensada a apreciação pelo Congresso Nacional ou pela Assembléia Legislativa, o decreto limitar-se-á a suspender a execução do ato impugnado, se essa medida bastar ao restabelecimento da normalidade."; $i$ ) inciso VI do art. 48: “incorporação, subdivisão ou desmembramento de áreas de Territórios ou Estados, ouvidas as respectivas Assembléias Legislativas.”; $j$ ) inciso III do art. 60: “A Constituição poderá ser emendada mediante proposta (...) de mais da metade das Assembléias Legislativas das unidades da Federação, manifestando-se, cada uma delas, pela maioria relativa de seus membros."; $k$ ) inciso IV do art. 103: "Podem propor a ação direta de inconstitucionalidade e a ação declaratória de constitucionalidade (...)

a Mesa de Assembléia Legislativa ou da Câmara Legislativa do Distrito Federal.”; $l$ ) inciso I do art. 235: "Nos dez primeiros anos da criação de Estado, serão observadas as seguintes normas básicas: I - a Assembléia Legislativa será composta de dezessete Deputados se a população do Estado for inferior a seiscentos mil habitantes, e de vinte e quatro, se igual ou superior a esse número, até um milhão e quinhentos mil;"; m) caput do art. 11 do ADCT: "Cada Assembléia Legislativa, com poderes constituintes, elaborará a Constituição do Estado, no prazo de um ano, contado da promulgação da Constituição Federal, obedecidos os princípios desta."

Os Deputados Estaduais e os Distritais, com mandato de quatro anos, compõem o Poder Legislativo dos vinte e seis Estados-membros e do Distrito Federal na Federação brasileira. Os critérios para se fixar o número de Deputados à Assembléia Legislativa e à Câmara Legislativa são preconizados pela Constituição Federal (arts. 27, caput; 32 , $\S 3^{\underline{o}} ; 45$, caput e $\S 1^{\underline{o}}$ ): corresponde ao triplo da representação do Estado na Câmara dos Deputados e, atingido o número de $36(12 \times 3)$, será acrescido de tantos quantos forem os Deputados federais acima de 12. Desta forma, ao Estado-membro 
mais populoso que, conforme a Lei Complementar $\mathrm{n}^{\mathrm{o}} 78$, é representado por 70 Deputados federais, corresponderá uma Assembléia Legislativa composta por 94 Deputados estaduais: $12 \times 3+(70-12){ }^{72}$

A Câmara dos Deputados compõe-se de representantes do povo, contudo, pelos critérios vigentes, não há proporcionalidade entre as vagas de Deputados federais com a população brasileira. É que o constituinte de 1988 assegurou, à época, a irredutibilidade da representação dos Estados e do Distrito Federal na Câmara dos Deputados $\left(\S 2^{-}\right.$do art. $4^{\circ}$ do ADCT) e manteve, basicamente, a estrutura imposta pelo "Pacote de Abril" de 1977, que assegurava número mínimo de representantes a Territórios e Estados. Daí não se aplicar, até hoje, a máxima da representação equânime: "Cada cabeça um voto". Aprofundaram-se, desse modo, as distorções e agravou-se o desvirtuamento da representação proporcional, notadamente em detrimento dos Estados-membros mais populosos. ${ }^{73}$

${ }^{72}$ Cf. Resolução n. 22.144, do TSE, de 14 de fevereiro de 2006, publicada no Diário da Justiça, de 22 de fev. 2006, Seção I, p. 123.

Para a legislatura que se inicia em 2007 e termina em 2011, a representação dos Estados e do Distrito Federal na Câmara dos Deputados será a abaixo transcrita. E, em relação à Câmara e Assembléias Legislativas, a legislatura que se inicia em 2007 e termina em 2011 terá o seguinte número de Deputados (as):

\begin{tabular}{|c|c|c|c|}
\hline \multicolumn{2}{|c|}{ CÂMARA DOS DEPUTADOS } & \multicolumn{2}{|c|}{ CÂMARA E ASSEMBLÉIAS LEGISLATIVAS } \\
\hline ESTADO & $\mathrm{N}^{\circ}$ DE DEP. & ESTADO & $\mathrm{N}^{\circ}$ DE DEP. \\
\hline São Paulo & 70 & São Paulo & 94 \\
\hline Minas Gerais & 53 & Minas Gerais & 77 \\
\hline Rio de Janeiro & 46 & Rio de Janeiro & 70 \\
\hline Bahia & 39 & Bahia & 63 \\
\hline Rio Grande do Sul & 31 & Rio Grande do Sul & 55 \\
\hline Paraná & 30 & Paraná & 54 \\
\hline Pernambuco & 25 & Pernambuco & 49 \\
\hline Ceará & 22 & Ceará & 46 \\
\hline Pará & 17 & Pará & 41 \\
\hline Maranhão & 18 & Maranhão & 42 \\
\hline Santa Catarina & 16 & Santa Catarina & 40 \\
\hline Goiás & 17 & Goiás & 41 \\
\hline Paraíba & 12 & Paraíba & 36 \\
\hline Espírito Santo & 10 & Espírito Santo & 30 \\
\hline Piauí & 10 & Piauí & 30 \\
\hline Alagoas & 9 & Alagoas & 27 \\
\hline Rio Grande do Norte & 8 & Rio Grande do Norte & 24 \\
\hline Amazonas & 8 & Amazonas & 24 \\
\hline Mato Grosso & 8 & Mato Grosso & 24 \\
\hline Mato Grosso do Sul & 8 & Mato Grosso do Sul & 24 \\
\hline Distrito Federal & 8 & Distrito Federal & 24 \\
\hline Sergipe & 8 & Sergipe & 24 \\
\hline Rondônia & 8 & Rondônia & 24 \\
\hline Tocantins & 8 & Tocantins & 24 \\
\hline Acre & 8 & Acre & 24 \\
\hline Amapá & 8 & Amapá & 24 \\
\hline Roraima & 8 & Roraima & 24 \\
\hline TOTAL & 513 & TOTAL & 1059 \\
\hline
\end{tabular}

${ }^{73}$ FARHAT, Saïd. Dicionário parlamentar e político: o processo político e legislativo no Brasil. São Paulo: Edit. Fundação Peirópolis: Cia Melhoramentos, 1996. p. 92-94, verbete Câmara dos Deputados, composição: desequilíbrio na representação das regiões. CUNHA, Sérgio Sérvulo da. 
Ao se estabelecer a obrigatoriedade da realização de eleições antes do término do mandato parlamentar, sedimenta-se, também, a ininterruptibilidade do Poder Legislativo.

O Poder Legislativo funciona em legislaturas que se sucedem. A legislatura dos Deputados Estaduais e Distritais dura quatro anos, coincide com o início e término do mandato parlamentar. Cada legislatura é una, daí defluindo o princípio da unidade da legislatura. A cada legislatura assegura-se o direito à própria independência, sem vínculos com os compromissos e decisões tomadas pela anterior, por isso mesmo, Comissões temporárias constituídas numa legislatura, como as Comissões Parlamentares de Inquérito, extinguem-se com o término daquela. ${ }^{74}$ No bojo de cada legislatura o Legislativo detém incumbências específicas dela decorrentes: eleger a Mesa diretora dos trabalhos; compor com novos membros as Comissões permanentes e instalar seu funcionamento; arquivar proposições da legislatura anterior na forma disciplinada no Regimento Interno. Enfim, à nova legislatura garante-se começar as atividades legislativas desvencilhada de obrigatoriedades ou compromissos políticos então assumidos pela que se findou.

As legislaturas dividem-se em sessões legislativas anuais. Durante o Império, a sessão legislativa anual das Assembléias Legislativas Provinciais durava dois meses, "podendo ser prorrogada quando o julgar conveniente o Presidente da Província" (art. $7^{\circ}$ do Ato Adicional de 1834). Praticamente continuou assim durante a República Velha, exceto em São Paulo, com funcionamento durante 4 meses, e Rio Grande do Norte, durante 1 mês, as sessões legislativas anuais do Poder Legislativo estadual duravam de 2 a 3 meses, iniciando-se em variadas datas, como já anteriormente anotado. Muito embora propalada a crise do Poder Legislativo, o fato é que, com o Estado-providência e também com o Estado-regulador, a sociedade exige, cada vez mais, que as Casas Legislativas permaneçam em funcionamento. Atualmente

Sistema eleitoral brasileiro. In Cadernos de direito constitucional e eleitoral. São Paulo: Imesp, v. 14, n⿳⺈ 48, p. 29-30, out./dez. 2000.

Resultados das eleições gerais de 2006 para o cargo de Deputado federal demonstram que, no Estado de Roraima, candidato com 8.153 votos foi eleito e, no Rio de Janeiro e em São Paulo, candidatos que obtiveram 93.513 e 92.854 votos, respectivamente, tornaram-se suplentes do PP e do PMDB. Resultados das eleições gerais de 2002 para o cargo de deputado federal demonstram igualmente que o voto vale mais no Estado de Roraima porquanto candidato que obteve 6.488 votos foi eleito e, em São Paulo, candidato com 127.977 ficou na suplência.

Ver http://www.tse.gov.br /eleições / resultados.

${ }^{74}$ Questão de Ordem n. 243, proferida na $18^{\text {a }}$ sessão extraordinária, em 11-07-07, publicada no Diário Oficial do Estado - Poder Legislativo, edição de 2-8-07, p. 51 (colunas 3 e 4) e p.52 (coluna 1). 
Assembléias Legislativas funcionam no mesmo período de reunião do Congresso Nacional: 02 de fevereiro a 17 de julho e de $1^{\circ}$ de agosto a 22 de dezembro. ${ }^{75}$ No entanto, inúmeras Assembléias têm outros diferentes períodos de funcionamento, como São Paulo, por exemplo, que, no primeiro ano da legislatura, inicia seus trabalhos em 15 de março e, nos demais anos, em $1^{\circ}$ de fevereiro até 30 de junho e em $1^{\circ}$ de agosto até 15 de dezembro, não interrompendo suas atividades, em 30 de junho, sem aprovação do projeto de lei de diretrizes orçamentária; da mesma forma, as atividades do Poder Legislativo não são interrompidas em 15 de dezembro sem a deliberação do projeto de lei do orçamento e sobre as contas prestadas pelo Governador, referentes ao exercício anterior. ${ }^{76}$ No caso paulista, o início da legislatura, fixado em 15 de março, foi confirmado pelo Supremo Tribunal Federal na ADI n. 1162-6/600 em liminar deferida em $1^{\circ}$ de dezembro de 1994, para garantir, à legislatura que se iniciaria em 1995, o mandato de quatro anos constitucionalmente previsto (art. 27, $\S 1^{\circ}$ ). É que os constituintes paulistas de 1989, que acumulavam também a condição de Deputados estaduais, não se impuseram uma autolimitação ao mandato de parlamentares que, finda a Constituinte, garantidamente conservariam, e o quiseram conservado pelo período de quatro anos, infligindo à legislatura seguinte, mediante disposição constitucional transitória (art. $1^{\circ}$ do ADCT), uma redução do mandato em 75 dias, para que a posse daqueles Deputados se desse em $1^{\circ}$ de janeiro, coincidindo com a posse do Governador. Ora, a posse dos Governadores restou fixada pela Constituição Federal (art. 28: $1^{\circ}$ de janeiro do ano subseqüente às eleições realizadas), mas a dos Deputados estaduais não. Como conseqüência, houve redução no mandato dos Governadores que haviam sido empossados antes da promulgação da Constituição Federal. Aos Deputados estaduais, a Constituição de 1988 garante o mandato de quatro anos, deixando in albis a data da posse; esse o fundamento da decisão judicial, da qual se infere também a possibilidade jurídica de haver diferentes

\footnotetext{
${ }^{75}$ Nesse sentido, as Assembléias Legislativas do Paraná, Acre, Rondônia, Rio Grande do Sul.

${ }^{76}$ Indagação que permeia esse assunto, inúmeras vezes suscitada em Questão de Ordem, diz respeito à matéria que remanesce para apreciação: somente o projeto de lei de diretrizes orçamentárias e nenhuma outra mais, ou esse projeto e todas as demais matérias em trâmite? Em resposta à Questão de Ordem já se entendeu que somente a tramitação do projeto de lei de diretrizes orçamentárias seria objeto da continuidade dos trabalhos legislativos, bem como razões foram aduzidas para concluir que todas as matérias em trâmite deveriam ser objeto de deliberação, afinal os trabalhos da Assembléia Legislativa como um todo não seriam interrompidos, transcorrendo-se normalmente todos os prazos previstos, constitucionais, legais e regimentais. Dar-se-ia como se tivesse havido prorrogação da sessão legislativa anual ordinária.

Questão de Ordem respondida na 192a sessão ordinária, de 16-12-97, publicada no Diário Oficial do Estado de São Paulo - Poder Legislativo, edição de 17-01-98, p. 1-2.
} 
períodos de funcionamento dos Legislativos Estaduais. Qualquer alteração constitucional que se pretenda introduzir para fazer coincidir o início dos mandatos dos respectivos Governadores com o dos parlamentares estaduais em todos os Estados deverá ser obra do constituinte federal, prevendo-se as devidas medidas de cunho transitório para conciliar as diferentes situações. Ao constituinte estadual não se permite alteração "para encurtar ou para ampliar os mandatos eletivos" 77.

\section{O funcionamento do Poder Legislativo Estadual efetiva-se em locus} próprio, na capital do respectivo Estado em regra, ${ }^{78}$ independentemente de convocação, para o período ordinário fixado por norma constitucional; ${ }^{79}$ o que demonstra a preocupação de afastar, interna ou externa corporis, a possibilidade de se controlar a atividade do Poder Legislativo, de funcionar ou não funcionar.

\footnotetext{
${ }^{77}$ STF - Pleno - ADI n. 3825-RR - Rel. Min. Cármen Lúcia Antunes Rocha, decisão: 13 dez. 2006, In Informativo $S T F$, n. 452.
}

"O Tribunal deferiu pedido de medida cautelar formulado em ação direta de inconstitucionalidade ajuizada pelo Partido da Frente Liberal - PFL, para suspender os efeitos da expressão "e, em 15 (quinze) de fevereiro para a posse", constante do $\S 4^{\circ}$ do art. 30 da Constituição do Estado de Roraima, com a redação que lhe foi conferida pela Emenda Constitucional 16/2005, que altera a data da posse dos Deputados estaduais eleitos em $1^{\circ} .10 .2006$. Entendeu-se que o dispositivo impugnado, a princípio, ofende o $\S 1^{\circ}$ do art. 27 da CF, que estabelece ser de 4 anos o mandato dos Deputados estaduais, haja vista que amplia, por mais 46 dias, o tempo de duração dos mandatos dos parlamentares estaduais da legislatura de 2003 a 2006. Precedente citado: ADI 1162/SP (DJU de 15.9.95). ADI 3825/RR, rel. Min. Cármen Lúcia, 13.12.2006. (ADI-3825)"

${ }^{78}$ Constituição de Minas Gerais - "Art. 53 - (...) $§ 4^{\circ}$ - Por motivo de conveniência pública e deliberação da maioria de seus membros, poderá a Assembléia Legislativa reunir-se, temporariamente, em qualquer cidade do Estado.

${ }^{79}$ Acre: 15 fev. a 30 jun. e de 01 ago. a 15 dez. (art.48)

Alagoas: 01 fev. a 30 jun. e de 01 ago. a 15 dez. (art.69)

Amapá: 02 fev. a 30 jun. e de 01 ago. a 22 dez. (art.100, com redação dada pela EC n. 41/2008)

Amazonas: 01 fev. a 16 jul. e de 01 ago. a 31 dez. (art.29, com redação dada pela EC n. 51/2005)

Bahia: 15 fev. a 30 jun. e de 01 ago. a 15 dez. (art.67, com redação pela EC n. 8/2000)

Ceará: 15 fev. a 30 jun. e de 01 ago. a 15 dez. (art.47)

Espírito Santo: 02 fev. a 17 jul. e de 01 ago. a 22 dez. (art. 58, com redação dada pela EC n. 50/2006)

Goiás: 15 fev. a 30 jun. e de 01 ago. a 15 dez. (art. 16)

Maranhão: 15 fev. a 30 jun. e de 01 ago. a 15 dez. (art. 29, com redação dada pela EC n. 14/1995)

Mato Grosso: 02 fev. a 17 jul. e de 01 ago. a 22 dez. (art. 34, com redação dada pela EC n. 49/2006)

Mato Grosso do Sul: 15 fev. a 30 jun. e de 01 ago. a 15 dez. (art. 53)

Minas Gerais: 01 fev. a 18 jul. e de 01 de ago. a 20 dez. (art. 53, com redação dada pela EC n. 74/2006.)

Pará: 15 jan. a 01 jul. e de 01 ago. a 20 dez. (art.99, com redação dada pela EC n. 32/2006)

Paraíba: 20 fev. a 20 jun. e de 20 jul. a 20 dez. (art.59, com redação dada pela EC n. 12/1999)

Paraná: 02 fev. a 17 jul. e de 01 ago. a 22 dez. (art.61, com redação dada pela EC. n. 20/2007)

Pernambuco: 01 fev. a 30 jun. e de 01 ago. a 30 dez. (art. $7^{\circ}$, com redação dada pela EC n. 28/2006)

Piaúi: 15 fev. a 30 jun. e de 01 ago. a 15 dez. (art. 80)

Rio de Janeiro: 01 fev. a 30 jun. e de 01 ago. a 31 dez. (art.107, com redação dada pela EC n. 33/2004)

Rio Grande do Norte: 15 fev. a 30 jun. e de 01 ago. a 15 dez. (art.42)

Rio Grande do Sul: 01 fev. a 16 jul. e de 01 de ago. a 22 dez. (art.50, com redação dada pela EC n. 52/2006)

Rondônia: 15 fev. a 30 jun. e de 01 ago. a 15 dez. (art. 28)

Roraima: 15 fev. a 30 jun. e de 01 de ago. a 15 dez. (art. $30, \S 2^{\circ}$ )

Santa Catarina: 02 fev. a 17 jul. e de 01 ago. a 22 dez. (art. 46, com redação dada pela EC n. 44/2006)

São Paulo: 01 fev. a 30 jun. e de 01 de ago. a 15 de dez. (art. $9^{\circ}, \S 1^{\circ}$ )

Sergipe: 15 fev. a 30 jun. e de 01 ago. a 15 dez. (art. 51)

Tocantins: 01 de fev. a 30 jun. e de 01 ago. a 15 dez. (art. 15) 
No entanto, durante o recesso, poderá a Assembléia Legislativa ser convocada extraordinariamente; nesse caso, a convocação poderá ser feita: $\boldsymbol{a}$ ) pelo Presidente da Assembléia nas hipóteses de decretação de estado de sítio ou de estado de defesa que atinja todo ou parte do território estadual; intervenção no Estado ou em Município; recebimento dos autos de prisão de Deputado, na hipótese de crime inafiançável; $\boldsymbol{b}$ ) pelo Presidente da Assembléia, pela maioria absoluta dos membros da Assembléia Legislativa ou pelo Governador, em caso de urgência ou interesse público relevante.

Observe-se que o constituinte federal, mediante EC n. 50/06, no caso de urgência e de interesse público relevante, condicionou a convocação extraordinária do Congresso Nacional - feita pelo Presidente da República, Presidentes da Câmara dos Deputados e do Senado Federal ou a requerimento da maioria dos membros de ambas as Casas - à aprovação da maioria absoluta de cada uma das Casas do Congresso. De fato, como conclui Alexandre de Moraes, "trata-se de alteração importante que fortalece o Poder Legislativo frente ao Presidente da República, que não mais poderá pautá-lo extraordinariamente sem prévia concordância da maioria absoluta de ambas as Casas Legislativas". ${ }^{80}$ As alterações sobre a matéria efetivadas após a edição da Emenda Constitucional Federal n. 50/06 nas Constituições Estaduais mineira (EC n. 74/2006), gaúcha (EC n. 52/2006), catarinense (EC n. 44/2006), amapaense (EC n. 41/2008), mato-grossense (EC n. 49/2006), paraense (EC n. 32/2006), paranaense (EC n. 20/2007) e pernambucana (EC n. 28/2006), não submeteram a convocação extraordinária da Assembléia Legislativa, feita monocraticamente pelo Governador do Estado nos casos de urgência ou de interesse público relevante, à aprovação de maioria absoluta dos Deputados Estaduais. Somente a Emenda Constitucional n. 50/2006 à Constituição do Espírito Santo prevê a concordância de maioria absoluta da Assembléia Legislativa em convocações extraordinárias do Poder Legislativo feitas pelo Governador ou pelo Presidente da Assembléia nos casos de urgência ou de interesse público relevante alegado.

$\mathrm{Na}$ sessão legislativa extraordinária, a Assembléia Legislativa somente delibera sobre a matéria para a qual foi convocada, todavia, admite-se, justificadamente, aditamento de matéria por quaisquer dos titulares do direito de convocação, tenham eles sido, ou não, os autores daquela convocação que se pretender

\footnotetext{
${ }^{80}$ Direito Constitucional. $21^{\text {a }}$ ed. São Paulo: Atlas, 2007, p. 393.
} 
aditar com matéria nova. Há Constituições, como a paulista, que não prevêem a convocação extraordinária do Poder Legislativo pelo seu Presidente nos casos de urgência ou de interesse público relevante, reservando-se a competência de autoconvocação por tais motivos tão-somente à maioria absoluta dos membros do Legislativo.

Decorrente do princípio da ininterruptibilidade do Poder Legislativo, há que se prever mecanismo para que, mesmo no recesso, em se necessitando, ele possa funcionar, o se dá por convocação extraordinária. Não se admite, no decorrer de uma convocação extraordinária da Assembléia Legislativa, é ela aprovar requerimento de não realização de sessões abrangendo o próprio período da convocação, numa burla à representação política depositada naquele colegiado, investido para exercício das funções precípuas constitucionalmente conferidas ao Poder Legislativo. Com efeito, o Estado, nessas condições, estaria desprovido deste Poder.

Durante o recesso e enquanto não houver convocação extraordinária do Poder Legislativo, sem prejuízo das atribuições da Mesa e de seus membros, funciona uma Comissão Representativa da Assembléia Legislativa com variadas funções, dentre as quais, as seguintes: receber petições, reclamações, representações ou queixas de qualquer pessoa contra atos ou omissões de autoridade ou entidade pública; propor a sustação de ato normativo do Poder Executivo que exorbite do poder regulamentar, elaborando o respectivo projeto de decreto legislativo; aprovar moção ou dirigir indicação aos poderes federais ou estaduais, sobre assunto de suas competências; conceder licença ao Governador e ao Vice-Governador para ausentar-se do Estado por mais de 15 dias; dar posse a substitutos do Governador e do Vice nos casos de impedimento ou vacância dos cargos.

Havendo urgência e relevância, há Regimentos de Assembléias (SP, art. 34-B, § 2º) que admitem, durante o recesso, o funcionamento de Comissão Parlamentar de Inquérito, mediante a aprovação da maioria dos membros da própria Comissão.

\subsubsection{Plenário}

O Poder Legislativo Estadual é um poder complexo, composto de vários órgãos; alguns com assento constitucional (Plenário, Comissões, Mesa, Presidência, Bancadas, Bloco Parlamentar, Líder da maioria, Líder da minoria), outros previstos no Regimento Interno (Colégio de Líderes, Conselho de Ética, Corregedoria, Ouvidoria), que disciplina também as atribuições de todos, tanto dos órgãos de extração constitucional como dos meramente regimentais. 
Em colegiados, como são os Parlamentos, o Plenário é o órgão máximo; nele residem as decisões finais, soberanas. É composto por todos os candidatos declarados eleitos e devidamente diplomados pela Justiça Eleitoral, conforme relação nominal oferecida por essa Justiça especializada, desde que esses candidatos compareçam pessoalmente, em data fixada pelos Regimentos Internos das Casas Legislativas, para, após proferir o compromisso regimental padrão, tomar posse no cargo eletivo, transformando-se em parlamentares, investindo-se, pois, em mandato representativo popular. Empossado, o parlamentar integra o Plenário, expressão concreta do próprio Poder Legislativo. Não há mais, por parte do Plenário, a competência para proceder à verificação de poderes; esta atribuição, de natureza eleitoral, fazia parte das competências do Poder Legislativo Estadual para seus membros, mas, desde 1934, com a criação de Justiça especializada para tanto, tornou-se incumbência da Justiça Eleitoral.

O Plenário funciona em sessões públicas ou, excepcionalmente, em sessões secretas. No Estado de São Paulo só pode haver sessões públicas, por expressa norma constitucional (art. 10). Há quorum para instalação da sessão, previsto por norma regimental, em regra. Diverso, no entanto, é o quorum de deliberação do colegiado legislativo. Em observância à regra da maioria, as deliberações somente podem ser tomadas por maioria de votos, presente maioria absoluta de seus membros. A respeito dos quóruns (de instalação dos trabalhos e deliberativo) tratar-se-á nos itens 7.5 e 7.7 infra.

\subsubsection{Mesa}

Órgão colegiado interno constitucionalmente previsto, as Mesas do Poder Legislativo estadual e distrital são compostas por presidente e, ao menos, por dois secretários. Há Assembléias Legislativas que prevêem em seus Regimentos Internos outras conformações. 


\begin{tabular}{|c|c|l|}
\multicolumn{4}{|c|}{ Mesa $^{81}$} \\
\hline Membros & Membros efetivos & \multicolumn{1}{|c|}{ Estados } \\
\hline 7 & 3 & $\begin{array}{l}\text { Acre, Amapá, Espírito Santo, Goiás, Mato Grosso do Sul, Minas } \\
\text { Gerais, Pará, Rio Grande do Norte, São Paulo }\end{array}$ \\
\hline 6 & 3 & Amazonas, Roraima e Sergipe \\
\hline 7 & 7 & Pernambuco \\
\hline 7 & 3 & Santa Catarina e Tocantins \\
\hline 8 & 3 & Bahia \\
\hline 8 & 4 & Distrito Federal \\
\hline 9 & 3 & Maranhão \\
\hline 10 & 4 & Paraná \\
\hline 11 & 5 & Ceará \\
\hline 12 & 3 & Rio Grande do Sul \\
\hline 13 & 5 & Paraíba \\
\hline
\end{tabular}

Fonte: Regimentos Internos

Constituições Estaduais estabelecem como atribuição de um dos membros da Mesa, o Presidente da Assembléia Legislativa, a função de substituir ou suceder o Governador e o Vice-Governador, temporária ou definitivamente, no caso de licenças ou impedimentos concomitantes, ou de dupla vacância, respectivamente. A Constituição do Estado de São Paulo, e.g., estabelece que, na hipótese de vacância dos cargos de Governador e de Vice-Governador no último ano do período governamental, o Presidente da Assembléia Legislativa será chamado ao exercício da Governança (arts. 40 e 41). No entanto, outras Constituições Estaduais, como a baiana, por exemplo, seguem o padrão da Constituição Federal: ocorrendo a vaga nos dois últimos anos do mandato governamental, far-se-á eleição para ambos os cargos, trinta dias depois da última vaga, mediante Colégio Eleitoral composto pelos membros da Assembléia Legislativa, e na forma que lei estadual disciplinar. A lei baiana sobre a matéria estatuiu escrutínio secreto no âmbito desse Colégio Eleitoral.

Na constituição das Mesas, há Cartas Estaduais que asseguram, tanto quanto possível, a representação proporcional dos partidos ou bloco parlamentares; outras garantem a representação proporcional dos partidos somente. A composição da Mesa é questão controversa, notadamente quando os parlamentares, eleitores e candidatos simultaneamente, não conseguem chegar a bom termo acerca dos cálculos da proporcionalidade partidária, no mais das vezes relativa, frise-se, havendo, por isso mesmo, norma de composição e acomodação desse conflito de interesses conformada na expressão de extração constitucional "tanto quanto possível”. Trata-se de questão interna corporis certamente, mas, do tanto quanto possível, não se infere sejam as

${ }^{81}$ Variações de Presidencialismos na Federação brasileira: processo político e reforma nos Estados, 1995-2006. São Paulo: FGV (Doutorado), 2007. p. 34. 
minorias parlamentares preteridas. Ademais, anote-se também que a Lei Federal $n$. 9.096/95 (art. 26) prevê a perda de cargo em órgão colegiado, como nos da Mesa, obtido em razão de proporcionalidade partidária, caso o parlamentar se desvincule do partido pelo qual originariamente fora eleito, efetivando no ato desvinculação partidária sem justa causa.

Ao serem empossados, todos os parlamentares estão em igualdade de condições. Após, por razão de ordem organizacional, elegem entre seus pares os que terão atribuições diferenciadas, delegando-lhes a direção do Poder. Somente por eleição são constituídas as Mesas das Casas Legislativas Estaduais, não havendo qualquer diferenciação entre os parlamentares para a escolha, seja ela decorrente de idade ou qualquer outra. Aliás, até mesmo a reeleição pode ser pleiteada ${ }^{82}$, muito embora algumas Constituições Estaduais vedem a reeleição para o mesmo cargo no biênio subseqüente, como a do Espírito Santo (art. 58, § 5º, Mato Grosso (art. 24, § $3^{\circ}$ ), Pernambuco (art. $7^{\circ}, \S 9^{\circ}$ ), Rio Grande do Sul (art. 49, $\S 4^{\circ}$ ), Santa Catarina (art. 46, $\S$ $3^{\circ}$ ) e a de São Paulo (art. 11, § 20); nos demais Estados a reeleição da Mesa está permitida por expressa disposição constitucional (Acre, art. 48, § 5; Alagoas, art. 70, parágrafo único; Amapá, art. 95, I; Amazonas, art. 29, § 4º II; Bahia, art. 67, § $3^{\circ}$;

${ }^{82}$ STF - Pleno - ADI-MC n. 1.528-AP - Rel. Min. Ellen Gracie - Decisão: 27 nov. 1996. In Diário da Justiça, de 05-10-2001, p. 39.

STF - Pleno - ADI n. 2292 - Rel. Min. Nelson Jobim - Decisão: 06 set. 2000. In Informativo STF n. 201:

"O art. 57, $\S 4^{\circ}$, da CF, que veda a recondução dos membros das Mesas das Casas Legislativas federais para os mesmos cargos na eleição imediatamente subsequiente, não é de reprodução obrigatória nas Constituições dos Estados. Com base nesse entendimento, o Tribunal indeferiu medida liminar em ações diretas ajuizadas pelo Partido Trabalhista Brasileiro - PTB e pelo Partido Socialista Brasileiro - PSB contra o $\S 3^{\circ}$ do art. 29 da Constituição do Estado do Maranhão (na redação dada pela EC 20/96), que permite a reeleição da Mesa Diretora da Assembléia Legislativa estadual. Vencido o Min. Marco Aurélio, que deferia a liminar. Precedentes citados: Rp 1.245-RN (RTJ 119/964); ADIn 793-RO (RTJ 163/52); ADIn 792-RJ (julgada em 26.5.97, acórdão pendente de publicação, v. Informativo 73); ADInMC 1.528-AP (julgada em 27.11.96, acórdão pendente de publicação, v. Informativo 55). ADInMC 2.262-MA e ADInMC 2.292-MA, rel. Min. Nelson Jobim, 6.9.2000.(ADI-2292)"

STF - Pleno - ADI n. 2371 - Rel. Min. Moreira Alves - Decisão: 07 mar. 2001. In Informativo STF n. 219:

"O art. 57, $\S 4^{\circ}$, da $\mathrm{CF}$, que veda a recondução dos membros das Mesas das Casas Legislativas federais para os mesmos cargos na eleição imediatamente subseqüente, não é de reprodução obrigatória pelos Estados-Membros. Com base nesse entendimento, o Tribunal, por maioria, indeferiu pedido de medida cautelar em ação direta de inconstitucionalidade, ajuizada pelo Partido Trabalhista Brasileiro - PTB, contra o $\S 5^{\circ}$ do art. 58 da Constituição do Estado do Espírito Santo, com redação dada pela EC 27/2000, que permite aos membros eleitos da Mesa da Assembléia Legislativa do Estado a recondução para o mesmo cargo no biênio imediatamente subseqüente. Vencidos os Ministros Marco Aurélio e Néri da Silveira, que deferiam o pedido de medida cautelar. Precedentes citados: ADInMC 1.528-AP (julgada em 27.11.96, acórdão pendente de publicação, v. Informativo 55), ADInMC 2.262-MA e ADInMC 2.292-MA (julgada em 6.9.2000, acórdão pendente de publicação, v. Informativo 201). ADInMC 2.371-ES, rel. Min. Moreira Alves, 7.3.2001.(ADI-2371)" 
Ceará, art. 47, § 2º Goiás, art. 16, § 3º; Maranhão, art. 29, § 3º Mato Grosso do Sul, art. 53, $4^{\circ}$; Minas Gerais, art. 53, § 3º II; Pará, art. 92, I; Paraíba, art. 59, § 4º; Piauí, art. $6^{\circ}$ do Regimento Interno; Rio Grande do Norte, art. 42, § $4^{\circ}$; Rio de Janeiro, art. $5^{\circ}$ do Regimento Interno; Rondônia, art. 29, I, alínea $b$; Roraima, art. 30, § 4º Sergipe, art. 51, $\S 5^{\circ}$; e Tocantins, art. 14, $\S 3^{\circ}$ ). No Paraná também ocorre reeleição da Mesa da Assembléia Legislativa, mas por interpretação, decorrente da inexistência de norma constitucional ou regimental sobre a matéria.

O modo como se procede à eleição dos membros da Mesa Diretora das Casas Legislativas vem sofrendo alterações. Constituições como a de São Paulo (art. $10, \S 2^{\circ}$ ), Paraná e Rio de Janeiro foram alteradas, nelas se abolindo o escrutínio secreto nas votações realizadas no Legislativo. Há questionamentos judiciais acerca dessas medidas ${ }^{83}$, mas as mudanças seriam corolário da premissa de que o mandato parlamentar é público. E, se o mandato é público, por que o voto seria secreto? Em relação à eleição dos membros da Mesa, o voto ostensivo poderia ser adotado, pois inserido no poder de auto-organização conferido pela Constituição Federal ao Poder Legislativo Estadual (art. 27, § 3º). Daí normas regimentais preverem voto aberto, cargo a cargo, ou eleição conjunta de todos os membros da Mesa, por chapa previamente registrada.

As Mesas Diretoras possuem inúmeras atribuições: dirigir os trabalhos legislativos; propor, privativamente, projetos para criação de cargos no âmbito da Secretaria da Assembléia Legislativa; apresentar projetos de lei para fixação dos subsídios do Governador, do Vice-Governador, dos Secretários de Estado (art. 28, § 2 , da CF) e dos parlamentares (art. 27, $\S 2^{\circ}$, da CF); analisar e encaminhar pedidos de informações a Secretários de Estado ou a quaisquer titulares de órgãos diretamente subordinados ao Governador (art. 50 da CF); encaminhar requerimentos de informações solicitados por parlamentar, individualmente, ou por Comissão, ao Procurador-Geral de Justiça, ao Procurador-Geral do Estado e ao Defensor Público Geral; promulgar Emendas Constitucionais; declarar a perda de mandato de parlamentar nos casos de: não comparência a um terço das sessões ordinárias na sessão legislativa anual; perda ou suspensão de direitos políticos; quando a Justiça Eleitoral

\footnotetext{
${ }^{83}$ ADI 2461/RJ; ADI 4.104/PR.
}

Como norma de preordenação para os Estados-membros, o escrutínio secreto vem previsto na Constituição Federal para escolha de Conselheiros do Tribunal de Contas do Estado indicados pelo Governador (art. 52, III, b, c.c. art. 75) e na perda de mandato parlamentar (art. 55, § $2^{\circ}$ c.c. art. 27, $\S$ $\left.1^{\circ}\right)$. 
decretar a perda do mandato; apresentar representação contra Deputado visando à perda do mandato nas hipóteses de infringência às incompatibilidades previstas constitucionalmente; procedimento incompatível com o decoro parlamentar; e quando o parlamentar sofrer condenação criminal em sentença transitada em julgado (art. 55 da CF); propor ação direta de inconstitucionalidade e ação declaratória de constitucionalidade (art. 103, IV, da CF); dirigir os serviços administrativos da Assembléia, e outras atribuições consignadas nos Regimentos Internos.

Como órgãos colegiados, as Mesas das Assembléias Legislativas organizam seus trabalhos nos moldes das Comissões e deliberam as matérias submetidas à sua apreciação pelo voto da maioria dos seus membros. Nas Mesas efetivas compostas por três membros (Presidente e dois Secretários), o "Secretário que discordar de determinada medida a ser consubstanciada em Ato, Decisão ou parecer apresentará seu voto em separado, assinando-o". Essa disposição, encontrada no Regimento Interno da Assembléia Legislativa do Estado de São Paulo, justifica-se para se evitar recusa na deliberação de alguma matéria submetida à apreciação do colegiado.

\subsubsection{Presidência}

A Constituição Federal reconhece a presidência do Poder Legislativo como órgão interno desse Poder. Esta conclusão assenta-se no disposto no art. 89, incisos II e III, e no art. 91, incisos II e III: “O Conselho da República é órgão superior de consulta do Presidente da República, e dele participam: o Vice-Presidente da República; o Presidente da Câmara dos Deputados; o Presidente do Senado Federal; os Líderes da maioria e da minoria da Câmara dos Deputados; os Líderes da maioria e da minoria no Senado Federal (...)”. No Conselho de Defesa Nacional (art. 91) há, igualmente, previsão da participação do Presidente da Câmara dos Deputados e o do Senado.

Para que seja órgão, necessário que haja atribuições. Com efeito, assim como a Constituição Federal confere ao Presidente da Câmara dos Deputados o direitodever de substituir o Presidente da República, as Constituições Estaduais incumbem aos Presidentes das Assembléias Legislativas a substituição e até a sucessão dos respectivos Governadores do Estado. Mais. No processo legislativo o Presidente da Assembléia promulga as leis decorrentes de sanção tácita do Governador, ou decorrentes de veto oposto a projeto pelo Governador, rejeitado pela Assembléia Legislativa, e não promulgado pelo Governador; incumbe-lhe convocar extraordinariamente o Poder Legislativo nas hipóteses previstas nos $\S \S 2^{\circ}$ e $3^{\circ}$ do art. 
36 da CF, nos casos de urgência e interesse público relevante, quando decretado estado de sítio ou estado de defesa que atinja todo ou parte do território estadual, na hipótese de recebimento dos autos de prisão de Deputado quando houver crime inafiançável; exerce o controle prévio de constitucionalidade das proposições; averigua se os requerimentos de constituição de Comissões Parlamentares de Inquérito preenchem os requisitos constitucionais; dá posse aos parlamentares; convoca sessões ordinárias e extraordinárias da Assembléia; elabora a Ordem do Dia de sessões; responde as questões de ordem suscitadas por parlamentares acerca de dúvida sobre a interpretação do Regimento Interno, na sua prática ou relacionada com as Constituições Federal e Estadual; preside o Colégio de Líderes; nomeia parlamentares para as Comissões à vista de indicação dos Líderes ou, também, quando omissa a indicação de Líder; compõe a Mesa Diretora.

\subsubsection{Bancadas, Minoria e Maioria parlamentar}

A Deputada ou o Deputado para exercer seus deveres e direitos inerentes ao mandato em que está investido poderá fazê-lo individualmente ou no âmbito de sua Bancada. A Constituição Federal, mediante preceito insculpido no inciso IV do artigo 17, consagrou o funcionamento parlamentar dos partidos políticos de acordo com a lei. A norma de regência, Lei n⿳ำ 9.096/95, que dispõe sobre Partidos Políticos, reconhece o legítimo funcionamento dos partidos políticos nas Casas Legislativas efetivando-se por intermédio de bancadas, que devem constituir suas lideranças de acordo com os respectivos estatutos partidários, as disposições regimentais das Casas correspondentes e as normas dessa própria lei, a qual fulminou com a perda da liderança o trânsfuga (arts. 12 e 26).

Constitui-se a bancada no órgão de atuação coletiva da representação partidária com assento na Casa Legislativa. Na Constituição, bem como no Regimento Interno da respectiva Casa, encontram-se os contornos das prerrogativas conformadoras do funcionamento parlamentar do partido político. Assim, e. g., no art. 55, $\S 2^{\underline{o}}$, da Constituição Federal, há menção a "partido político representado no Congresso Nacional" para conferir-lhe o direito de apresentar representação visando à perda de mandato de qualquer parlamentar.

O legislador ordinário federal, dispondo sobre funcionamento parlamentar do partido político (art. 18, IV, da CF), determinou a perda automática da função ou cargo exercido por parlamentar em decorrência da proporcionalidade partidária na 
respectiva Casa Legislativa, caso ele abandone o partido sob cuja legenda tenha se elegido (art. 26 da Lei Federal no 9.096, de 19 de setembro de 1995). Esse dispositivo fortalece as Bancadas partidárias e se aplica em todas as Câmaras Municipais, Câmara Legislativa e Assembléias Legislativas, Câmara dos Deputados e Senado.

Às Bancadas os Regimentos Internos reconhecem, e.g., o direito ao encaminhamento de votação; obstrução parlamentar legítima mediante ausência à votação previamente comunicada por seu Líder; participação no Colégio de Líderes; e a faculdade de constituírem Bloco Parlamentar. As Constituições Estaduais garantem às Bancadas participação nas Comissões e na Mesa observada, tanto quanto possível, a proporcionalidade partidária.

$\mathrm{Na}$ democracia representativa, há partido(s) político(s) que apóia(m) o governo e outro(s) que lhe faz(em) oposição. Dessa premissa decorre, nos Regimentos Internos, a seguinte conceituação: “Constitui a Maioria o Partido ou Bloco Parlamentar integrado pela maioria absoluta dos membros da Casa, considerando-se Minoria a representação imediatamente inferior que, em relação ao Governo, expresse posição diversa da Maioria." A Constituição Federal faz menção a Líderes da Maioria e da Minoria na Câmara dos Deputados e no Senado (art. 89, incisos IV e V), pressupondo a existência da Bancada majoritária e da minoritária. Observe-se que a Bancada minoritária não é, necessariamente, a Bancada com menor número de parlamentares. A Bancada minoritária pode até vir a ser a segunda maior representação partidária no Poder Legislativo. A condição para uma Bancada ser a Bancada da Minoria encontra-se na posição política que expresse em relação ao Governo. Assim, pode mesmo haver Bancada da Maioria que expresse oposição ao Governo; mas isso também não significa necessariamente que o Governo não tenha maioria de votos no Parlamento, a não ser que haja bipartidarismo. A definição de Maioria e Minoria parlamentar, pois, relativiza-se sempre pela posição que a representação partidária expresse em relação ao Governo. Não se confunde com o direito de minoria, assegurado a uma minoria parlamentar de um terço dos membros, por exemplo, para constituir Comissão Parlamentar de Inquérito, independentemente de deliberação que seria tomada pela maioria de todos os membros do Colegiado parlamentar.

As Bancadas possuem Líderes que, conforme norma regimental, são os porta-vozes de uma representação partidária (com assento na Casa Legislativa) e o intermediário autorizado entre ela e os órgãos do Poder Legislativo. Às Bancadas da 
Maioria e da Minoria confere-se, ainda, o direito de constituírem os respectivos Líderes dessa condição.

\subsubsection{Colégio de Líderes}

Uma das grandes dificuldades e, talvez, a maior causa de entrave dos trabalhos de um Parlamento é a falta de um calendário legislativo elaborado com antecedência entre o seu Presidente e os Líderes, definindo o conteúdo das Ordens do Dia das sessões. O calendário legislativo garante à coletividade a previsibilidade de decisão sobre determinado assunto submetido à apreciação do Legislativo. E a organização da Ordem do Dia é uma das tarefas mais importantes conferidas ao Colégio de Líderes, presidido pelo Presidente do Parlamento.

Norma de grandeza constitucional prevista na Constituição da República Portuguesa (art. 176, 3), por exemplo, garante a minorias parlamentares determinar a Ordem do Dia de certo número de sessões. No Brasil, normas constitucionais existentes sobre inclusão de matéria na Ordem do Dia tutelam principalmente projetos de iniciativa do Poder Executivo, como as medidas provisórias (art. 62, $\S 6^{\circ}$, da CF), projetos de iniciativa exclusiva com solicitação de urgência do Executivo (art. 64, § $2^{\circ}$ ) e projeto de lei de diretrizes orçamentárias (art. 57, § $2^{\circ}$, da $\mathrm{CF}$ ). No âmbito das Constituições Estaduais, inclui-se ainda o projeto de lei orçamentária anual, também de iniciativa exclusiva do Executivo, mais as contas prestadas pelo Governador, presumidamente de interesse do Executivo, mas consubstanciadas em projetos de decreto legislativo de iniciativa da Comissão de Finanças da Assembléia (art. $9^{\circ}, \S 4^{\circ}$, da Constituição do Estado de São Paulo). Anotem-se, ainda, os projetos de lei vetados que, por força de preceito constitucional, também devem ser incluídos em Ordem do Dia após trinta dias do recebimento das respectivas razões do veto. As demais regras sobre composição de Ordem do Dia têm assento regimental; aí o espaço de atuação do Colégio de Líderes, posto designadamente como instância de organização da Ordem do Dia. Este órgão do Poder Legislativo decide por consenso e quando ele não for possível, prevalece o critério da maioria absoluta, ponderados os votos dos Líderes de cada Partido em função da expressão numérica de sua Bancada.

\subsubsection{Comissões}

Todas as Constituições Estaduais prevêem, como faz a Federal (art. 58), que as Assembléias Legislativas terão comissões permanentes (as que subsistem através das 
legislaturas) e temporárias (as que se extinguem com o término da legislatura ou, antes dele, quando preenchido o fim a que se destinam), constituídas na forma e com atribuições previstas no respectivo Regimento Interno ou no ato de que resultar sua criação. Os trabalhos legislativos, pois, também se desenvolvem no âmbito das comissões parlamentares.

A Constituição Federal (art. 58, $\S 1^{\circ}$ ) e as Estaduais estabelecem, como reserva de Regimento, que, na constituição das comissões permanentes e temporárias, as normas regimentais assegurem, tanto quanto possível, a representação proporcional dos partidos ou dos blocos parlamentares que participam da respectiva Casa Legislativa. A Constituição do Estado de São Paulo, no entanto, não inclui na proporcionalidade da representação os blocos parlamentares.

\subsection{Permanentes}

Constituem-se, dentre outras, atribuições das comissões permanentes e já previstas constitucionalmente: a) discutir e votar projeto de lei que dispensar, na forma do regimento, a competência do Plenário, salvo se houver recurso de um décimo dos membros da Casa; b) realizar audiências públicas com entidades da sociedade civil; c) convocar Secretários de Estado para prestar informações sobre assuntos inerentes a suas atribuições; d) receber petições, reclamações, representações ou queixas de qualquer pessoa contra atos ou omissões das autoridades ou entidades públicas; e) solicitar depoimento de qualquer autoridade ou cidadão; f) apreciar programas de obras, planos de desenvolvimento e sobre eles emitir parecer. O rol de competências das comissões que os Regimentos Internos, ex vi de preceito constitucional, devem observar ao fixar-lhes as atribuições é considerável, quase resvalando, como consta em oportuno comentário feito por Manoel Gonçalves Ferreira Filho à Constituição Federal anterior, no surgimento de um "direito constitucional regimental" 84 , tantas as determinações impostas ao legislador regimental pelo constituinte.

Também porque os Regimentos Internos das Assembléias Legislativas prevalecem de uma legislatura para outra, sabe-se, de antemão, quantas são as comissões permanentes; quais suas competências e quantos os seus membros, muito embora em algumas Assembléias Legislativas a composição das comissões esteja adstrita à fixação estipulada pelo Colégio de Líderes (Rio Grande do Norte) ou pela

\footnotetext{
${ }^{84}$ Comentários à Constituição Brasileira, 5. ed., p. 193.
} 
Mesa (Espírito Santo e Paraíba). Por serem permanentes integram, evidentemente, a estrutura do próprio Poder Legislativo e, em regra, emitem parecer acerca de matérias ou assuntos submetidos ao seu exame, mediante deliberação da maioria de seus componentes e, havendo previsão regimental, deliberam conclusiva ou terminativamente sobre determinados projetos de lei, como previstos em Regimento Interno.

Para se ter uma visão sistematizada do número de comissões permanentes e sua composição nas Assembléias e Câmara Legislativas, há percuciente pesquisa aos respectivos Regimentos Internos realizada por Roberta Clemente ${ }^{85}$ :

Número e Composição das Comissões Permanentes nos Estados e no Distrito Federal

\begin{tabular}{|c|c|}
\hline $\begin{array}{c}\text { Composição } \\
\text { fixa } \\
\text { estabelecida } \\
\text { pelo Regimento } \\
\text { Interno }\end{array}$ & 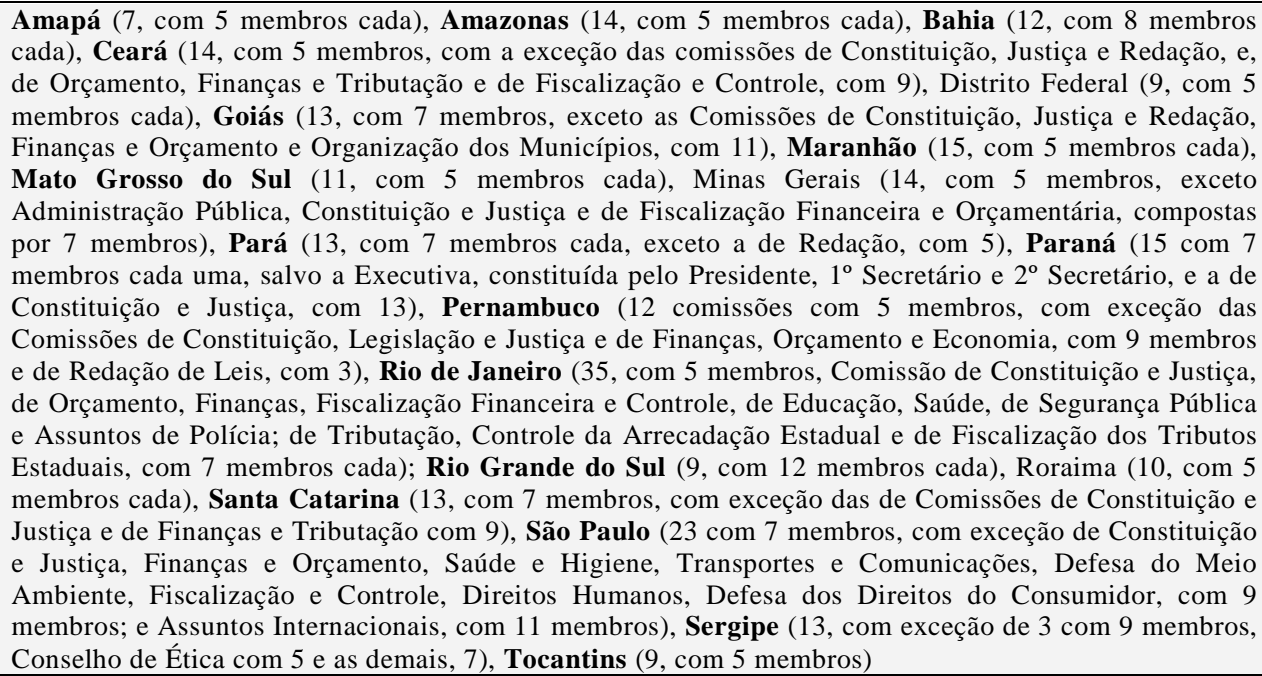 \\
\hline $\begin{array}{c}\text { Composição } \\
\text { determinada pela } \\
\text { Mesa } \\
\end{array}$ & Espírito Santo, Paraíba \\
\hline $\begin{array}{c}\text { Composição } \\
\text { determinada pelo } \\
\text { Colégio de Líderes }\end{array}$ & Rio Grande do Norte \\
\hline $\begin{array}{c}\text { Composição } \\
\text { determinada no } \\
\text { início da legislatura }\end{array}$ & Acre \\
\hline
\end{tabular}

Fonte: Regimentos Internos

Bem assim, a autora, em outra tabela, constata, em análise sintética, os sistemas das comissões permanentes previstos nos Regimentos Internos.

${ }^{85}$ Variações de Presidencialismos na Federação brasileira: processo político e reforma nos Estados, 1995-2006. São Paulo: FGV (Doutorado), 2007. p. 54-61. 
Esquema Sintético do Sistema de Comissões Permanentes

\begin{tabular}{|c|c|c|c|}
\hline & $\begin{array}{l}\text { Comissões Permanentes com } \\
\text { Poderes Terminativos }\end{array}$ & $\begin{array}{l}\text { Comissões Permanentes } \\
\text { sem Poderes } \\
\text { Terminativos }\end{array}$ & $\begin{array}{l}\text { Decisões das Comissões } \\
\text { permanentes submetidas } \\
\text { ao referendo do Plenário }\end{array}$ \\
\hline $\begin{array}{l}\text { Comissões Especiais para Propostas } \\
\text { de Emendas à Constituição, } \\
\text { projetos de Complementar, de lei } \\
\text { delegada, ou propostas que devam } \\
\text { ser analisadas por mais de três } \\
\text { comissões permanentes }\end{array}$ & $\begin{array}{l}\text { Amazonas, Bahia, Espírito Santo } \\
\text { (o Plenário deve decidir pela } \\
\text { criação de Comissão Especial), } \\
\text { Mato Grosso do Sul, Minas } \\
\text { Gerais, Paraíba, Paraná, Rio } \\
\text { Grande do Norte, Roraima, }\end{array}$ & $\begin{array}{l}\text { Acre, Distrito Federal } \\
\text { (apenas para o mérito, } \\
\text { CCJ analisa a } \\
\text { admissibilidade), Pará }\end{array}$ & \\
\hline $\begin{array}{l}\text { Comissões Permanentes analisam } \\
\text { todas as matérias legislativas (com } \\
\text { exceção de Relator Especial) }\end{array}$ & $\begin{array}{l}\text { Amapá, Ceará, Goiás, Maranhão, } \\
\text { Rio de Janeiro, Santa Catarina, } \\
\text { São Paulo }\end{array}$ & $\begin{array}{l}\text { Pernambuco, Sergipe, } \\
\text { Tocantins }\end{array}$ & São Paulo \\
\hline $\begin{array}{l}\text { Comissões especiais criadas sob } \\
\text { condições específicas }\end{array}$ & $\begin{array}{l}\text { Rio Grande do Sul (apenas para } \\
\text { matéria relevante não prevista } \\
\text { dentre as de competência das } \\
\text { Comissões Permanentes, assim } \\
\text { entendida pelo Plenário, podendo } \\
\text { funcionar no máximo duas ao } \\
\text { mesmo tempo) }\end{array}$ & & \\
\hline
\end{tabular}

Fonte: Regimentos Internos

Há que se anotar, preliminarmente, que a expressão "sistema de comissões" diz respeito à organização do próprio Parlamento, onde as decisões plenárias do Poder Legislativo são tomadas após análise, ao menos, de uma comissão permanente; ou à atribuição outorgada à comissão para deliberar sobre proposituras, na forma disposta em Regimento Interno. No sistema de comissões adotado pelas Assembléias Legislativas, as comissões discutem e votam projetos de lei; e opinam, mediante parecer, acerca de proposições; recebem petições, reclamações, representações ou queixas de qualquer pessoa contra atos ou omissões de autoridades ou entidades públicas; também mediante parecer opinam sobre papéis submetidos à sua apreciação. $\mathrm{Na}$ feitura das leis podem propor emendas, até mesmo substitutivas, participando efetivamente do aprimoramento das proposições legislativas, as quais somente podem ser incluídas em Ordem do Dia se instruídas com pareceres das comissões para onde tenham sido distribuídas; exceto projetos de lei vetados (após trinta dias de tramitação) e os projetos de autoria do Governador com solicitação de urgência (após quarenta e cinco dias da urgência solicitada), os quais não dependem de parecer das comissões, se esgotado o prazo a elas concedido e eles (os pareceres) não tiverem sido exarados. $\mathrm{O}$ Regimento Interno da Assembléia Legislativa do Estado de São Paulo chega até a substituir a manifestação do colegiado, depois de esgotado o prazo a ele fixado, pela de um único parlamentar, denominado Relator Especial que, para se desincumbir desta tarefa, exara igualmente um parecer; não se prescindindo, até mesmo nesse caso, de parecer, porquanto considerado como se da comissão fosse.

\subsection{Temporárias}


A função fiscalizatória, típica do Poder Legislativo, é exercida, também, por intermédio das Comissões Parlamentares de Inquérito. Para o cumprimento desse desiderato, todas as Constituições Estaduais afeiçoaram-se às disposições da Constituição Federal sobre a matéria (art. 58, § $3^{\circ}$ ) e estabeleceram: as comissões parlamentares de inquérito, que terão poderes de investigação próprios das autoridades judiciais, além de outros previstos no Regimento Interno, serão criadas mediante requerimento de um terço dos membros da Assembléia Legislativa, para apuração de fato determinado e por prazo certo, sendo suas conclusões, quando for o caso, encaminhadas aos órgãos competentes do Estado para que promovam a responsabilidade civil e criminal de quem de direito.

Registre-se que as Constituições Estaduais de 1947 não dispuseram expressamente sobre criação de Comissão Parlamentar de Inquérito, mas nem por isso elas deixaram de ser criadas. Andyara Klopstock Sproesser observa que a denominação então dada a elas no Estado de São Paulo, Comissão Especial de Inquérito - CEI, foi depois assim prevista na Constituição Estadual paulista de 1967. Em tese sobre CPI, registra a origem da denominação Comissão Especial de Inquérito:

“(...) essa expressão passou a ser adotada em face de parecer do eminente professor Vicente Ráo proferido, sob o regime da Constituição Federal de 1946 e da Constituição do Estado de São Paulo de 1947, em resposta à consulta que lhe fez a Assembléia Legislativa do Estado, sobre a possibilidade de criar comissões de inquérito. Mesmo diante da falta de previsão expressa desses órgãos na Constituição do Estado e no Regimento da Assembléia Legislativa, não hesitou o eminente mestre em responder pela afirmativa, argumentando que o inquérito parlamentar é da essência do Legislativo e que os órgãos dele incumbidos poderiam ser chamados, no caso paulista, de comissões especiais de inquérito, uma vez que no Regimento Interno estava prevista a criação de comissões especiais, para fins específicos, de conseguinte também para fins de inquérito." 86

Sobre a criação das Comissões Parlamentares de Inquérito, postas como órgãos essenciais para a consecução da função fiscalizadora, típica do Poder Legislativo, tanto do federal como dos Legislativos Estaduais, Distrital e dos Municipais, portanto, nas razões de decidir dos votos do Min. Celso de Melo, sobretudo, o Supremo Tribunal Federal assentou os alicerces doutrinários da

${ }^{86}$ Comissão Parlamentar de Inquérito - CPI no ordenamento jurídico brasileiro. São Paulo: USP (Doutorado), 2006, p. 221. 
fundamentação jurídico-constitucional sob a premissa de que são órgãos vocacionados à garantia de atuação de uma minoria parlamentar, a minoria composta por um terço de parlamentares; de modo que, submeter a sua criação - subscrita por um terço de parlamentares - à deliberação de todos membros do Legislativo seria uma burla ao direito desta minoria (de um terço), constitucionalmente previsto para criação de CPI. ${ }^{87}$

O Min. Eros Grau manteve as mesmas premissas acima expostas para criação de CPI como um direito de minoria e fundamentou, no pacto federativo, a sua compulsória observância pelos Estados. Verbis: "em decorrência do pacto federativo, o modelo federal de criação e instauração das comissões parlamentares de inquérito constitui matéria a ser compulsoriamente observada pelas casas legislativas estaduais". ${ }^{88}$ Sobre a fundamentação, é de se anotar o constatado por estudiosos da matéria, que a Federação brasileira não se formou nem se mantém por um pacto ${ }^{89}$, não sendo este o fundamento para compulsória observância pelos Legislativos dos Estadosmembros das regras de criação previstas na Constituição Federal. Nas funções precípuas do Poder Legislativo, dentre elas a de fiscalização político-administrativa, assenta-se a premissa para criação de Comissão Parlamentar de Inquérito no Poder Legislativo, seja ele o federal, estadual, distrital ou municipal, não havendo na

${ }^{87}$ STF - Pleno - MS 24.831-DF; MS 24.845-DF; MS 24.846-DF; MS 24.847-DF; MS 24.848-DF; MS 28.849-DF, Rel. Min. Celso de Mello, decisão: 22-06-2005. Informativo STF n. 393.

${ }^{88}$ STF - Pleno - ADI n. 3.619-SP - Rel. Min. Eros Grau.

89 “O Estado federal é formado por uma associação de Estados e essa associação tanto poderá decorrer de aglutinação histórica e real, quando Estados preexistentes criam o Estado Federal, como de imputação normalmente, mediante a criação jurídica dos Estados no documento de fundação do Estado Federal. Num caso e no outro, embora a criação real do Estado Federal possa ser precedida pela aliança, o pacto ou tratado de Estados independentes e soberanos, a Constituição Federal é o instrumento de criação jurídico-positiva do Estado Federal, encerrando a decisão fundamental sobre a forma de Estado.

No federalismo brasileiro, identificamos o segundo processo de criação do Estado Federal, quando a associação normativa dos Estados, operada pela Constituição, gerou o simultâneo nascimento jurídico do Estado Federal e dos Estados componentes, que passam a integrar a República Federativa. A Constituição Federal de 1891, que implantou a República Federal, é a fonte da criação originária do Estado-membro, por um processo jurídico-normativo. Com efeito, dispunha o artigo $1^{\circ}$ da Constituição Federal de 24 de fevereiro de 1891, que a República Federativa e os Estados Unidos do Brasil decorriam da "união perpétua e indissolúvel das suas antigas Províncias", para, na regra seguinte, tornar explícito que "cada uma das antigas Províncias formará um Estado" constitucional. (...) A Constituição posterior à de 1891, que foi a responsável pela criação jurídica do Estado-membro dentro do Estado Federal, opera em outro plano, partindo do Estado preexistente, com a finalidade de definir o quadro constitucional das competências e da organização do Estado-membro na Constituição Federal. Quero dizer, entre uma Constituição Federal e outra, na sucessividade histórica de Constituições Federais, o Estado-membro não se reintegra na Província, da qual ele proveio juridicamente. Perdura na condição jurídica de Estado, que não desaparece, para ser confirmado sucessivamente, em cada Constituição Federal.” HORTA, Raul Machado. Brasília: Ed. Brasília Jurídica, 1992. O Estado-membro na Constituição Federal Brasileira. p.333-4. 
Constituição Federal principio constitucional expresso nem norma alguma de préordenação impedindo que se garanta, a uma minoria menor que a de um terço, o direito de criar comissão parlamentar de inquérito. É o que ocorre, e.g., no Estado do Ceará, cuja Constituição exige subscrição de 1/4 dos membros da Assembléia Legislativa para criação de CPI (art. 56); ou de 1/5 dos parlamentares, como ocorria no Pará (art. 101, § $\left.4^{\circ}\right)^{90}$, conforme demonstra tabela sobre "Regras para criação de CPIs", elaborada por Roberta Clemente ${ }^{91}$ :

Regras para Criação de CPIs

\begin{tabular}{|c|c|c|c|c|c|}
\hline & $\begin{array}{c}\text { Requerimento } \\
\text { de } 1 / 5 *\end{array}$ & $\begin{array}{l}\text { Requerim } \\
\text { ento de } 1 / 4\end{array}$ & $\begin{array}{c}\text { Req. de } 1 / 3 \text { ou } \\
\text { individual aprovado } \\
\text { em Plenário }\end{array}$ & Requerimento de $1 / 3$ & $\begin{array}{c}\text { Requerimento de } \\
1 / 3 \text { e aprovação } \\
\text { do Plenário }\end{array}$ \\
\hline $\begin{array}{l}\text { Sem restrição ao } \\
\text { número máximo de } \\
\text { CPIs concomitantes }\end{array}$ & Pará * & & & $\begin{array}{c}\text { Amazonas, Rio Grande } \\
\text { do Norte, Rio Grande do } \\
\text { Sul, Santa Catarina }\end{array}$ & \\
\hline $\begin{array}{l}\text { Máximo } 7 \text { CPIS } \\
\text { concomitantes }\end{array}$ & & & & Rio de Janeiro & \\
\hline $\begin{array}{l}\text { Máximo } 6 \text { CPIS } \\
\text { concomitantes }\end{array}$ & & & & Minas Gerais & \\
\hline $\begin{array}{l}\text { Máximo } 5 \text { CPIS } \\
\text { concomitantes }\end{array}$ & & & Paraná & $\begin{array}{l}\text { Bahia, Espírito Santo, } \\
\text { Maranhão, Paraíba, } \\
\text { Pernambuco, } \\
\text { São Paulo }\end{array}$ & $\begin{array}{l}\text { Goiás, } \\
\text { Roraima }\end{array}$ \\
\hline $\begin{array}{l}\text { Máximo } 3 \text { CPIS } \\
\text { concomitantes }\end{array}$ & & & & $\begin{array}{l}\text { Mato Grosso do Sul, } \\
\text { Sergipe }\end{array}$ & $\begin{array}{l}\text { Acre, } \\
\text { Amapá }\end{array}$ \\
\hline $\begin{array}{l}\text { Máximo } 2 \text { CPIS } \\
\text { concomitantes }\end{array}$ & & Ceará & & & $\begin{array}{c}\text { Distrito Federal, } \\
\text { Tocantins }\end{array}$ \\
\hline
\end{tabular}

Fonte: elaboração própria, a partir de consultas às Constituições Estaduais e Regimentos Internos.

Muito embora concebidas como órgãos vocacionados à efetivação do direito de minoria parlamentar, as Comissões Parlamentares de Inquérito, após sua criação por uma minoria, devem observar, no ato de sua constituição, tanto quanto possível, a proporcionalidade dos partidos políticos. Decorre daí, em ordem à observância desse preceito constitucional de garantia da proporcionalidade partidária em sua composição, a desconstituição, de fato, do direito daquela minoria que a criara. Paradoxalmente, o direito da minoria de criar Comissão Parlamentar de Inquérito, cede passo à proporcionalidade partidária, sempre equacionada sob fórmulas que garantem às representações majoritárias o direito à participação, também majoritária, nas Comissões. De modo que a Comissão Parlamentar de Inquérito refletirá, em sua composição, a correlação de forças políticas representadas no Parlamento como um todo, e não a da minoria parlamentar que a crie.

Sobre se os Legislativos dos Estados-membros, por suas Comissões Parlamentares de Inquérito, detêm, ou não, poder para, independentemente de

\footnotetext{
90 * A Emenda Constitucional paraense n. 34, de 07 de jun. 2006, alterou de 1/5 para 1/3 o número mínimo de subscritores para criação de CPI.

${ }^{91}$ Variações de Presidencialismos na Federação, ob. cit., p. 61.
} 
prévia autorização judicial, determinar a quebra do sigilo bancário, o Supremo

Tribunal Federal, no voto condutor do Min. Joaquim Barbosa, por maioria, concedeulhes essa atribuição, não sem antes fixar uma série de premissas, de estreito interesse com o estudo que ora se procede, e daí os vários excertos transcritos do voto. ${ }^{92}$ Observou o eminente Ministro que se tratava, no caso, “da própria noção de equilíbrio federativo e a garantia aos Estados-membros de exercício, por um de seus poderes, de prerrogativas essenciais em nossa atual conformação das instituições públicas". É que o art. $4^{\circ}$ da Lei Complementar Federal n. 105, de 10 de janeiro de 2001, dispondo sobre o sigilo das operações das instituições financeiras, só concedia tal competência às Casas Congressuais, não às Assembléias Legislativas. ${ }^{93}$

No entender do eminente Ministro Relator, a matéria haveria de ser analisada sob a perspectiva do princípio federativo:

“(...) entendo que essa matéria há de ser examinada à luz do princípio federativo. Como eu disse, a questão deve ser vista sob uma perspectiva estrutural e sistemática, tendo como norte o princípio federativo.

Já advertiu o eminente Min. Sepúlveda Pertence, no julgamento da ADI 98 (cf. igualmente a ADI 1749, pleno 18.12.1997, rel. Min. Sepúlveda Pertence), ao tratar do princípio da separação de poderes, que para este não há "fórmula universal apriorística", sendo necessário extrair da atual Constituição o traço essencial da atual ordem, para efeito de controle de constitucionalidade das normas constitucionais estaduais, sobretudo em face do que o Min. Pertence descreve como: "... uma terceira modalidade de limitações à autonomia constitucional dos Estados: além dos grandes princípios e das vedações - esses e aqueles, implícitos ou explícitos - hão de acrescentar-se as normas constitucionais centrais que, não tendo o alcance dos princípios, nem o conteúdo negativo das vedações, são, não obstante, de absorção compulsória - com ou sem reprodução expressa - no ordenamento parcial dos Estados e Municípios."

92 STF - Pleno - ACO n. 730-RJ - Rel. Min. Joaquim Barbosa - Decisão: 22-09-2004. Informativo STF n. 362.

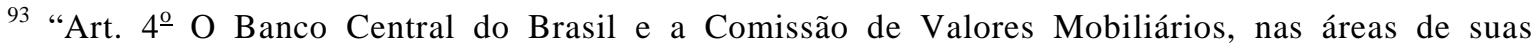
atribuições, e as instituições financeiras fornecerão ao Poder Legislativo Federal as informações e os documentos sigilosos que, fundamentadamente, se fizerem necessários ao exercício de suas respectivas competências constitucionais e legais.

$\S 1^{\underline{0}}$ As comissões parlamentares de inquérito, no exercício de sua competência constitucional e legal de ampla investigação, obterão as informações e documentos sigilosos de que necessitarem, diretamente das instituições financeiras, ou por intermédio do Banco Central do Brasil ou da Comissão de Valores Mobiliários.

$\S 2^{\circ}$ As solicitações de que trata este artigo deverão ser previamente aprovadas pelo Plenário da Câmara dos Deputados, do Senado Federal, ou do plenário de suas respectivas comissões parlamentares de inquérito." 
Entendo que a possibilidade de criação de comissões parlamentares de inquérito seja uma dessas normas de "absorção compulsória" nos estados-membros, destinada a garantir o potencial do poder legislativo em sua função de fiscal da administração.

Assim, em nossa estrutura federativa, um dos traços fundamentais da separação de poderes - que é a fiscalização da administração pelo Legislativo reforçada pelos meios a ela inerentes - não autoriza eventual pretensão restritiva dos Estados-membros."

E, malgrado revelada uma terceira modalidade de limitação à autonomia dos Estados, a decorrente de "normas constitucionais centrais", assentada em preceito amplo e sujeito à hermenêutica oportuna para se ampliar ou restringir a própria autonomia dos Estados-membros, o fato é que o eminente Min. Joaquim Barbosa, fundamentou nessa terceira modalidade de limitação, a ampliação da autonomia do Estado, pois "a fiscalização da administração pelo Legislativo reforçada pelos meios a ela inerentes não autoriza eventual pretensão restritiva aos Estados-membros”.

Na síntese do próprio Relator: “a quebra de sigilo bancário por parte das comissões parlamentares de inquérito constitui instrumento inerente ao exercício da função fiscalizadora ínsita aos órgãos legislativos e, como tal, dela também podem fazer uso as CPIs instituídas pelas Assembléias Legislativas, desde que observados os requisitos e as cautelas preconizadas em inúmeras decisões desta Corte sobre o tema”.

Acerca desses requisitos e cautelas, o inciso VII do art. 34-B da XIII consolidação do Regimento Interno da Assembléia Legislativa do Estado de São Paulo já dispõe:

“A Comissão Parlamentar de Inquérito poderá, observada a legislação específica:

VII - determinar a quebra do sigilo bancário, fiscal e de dados telefônicos, requisitando as respectivas informações dos agentes e órgãos públicos competentes, desde que observados os seguintes requisitos:
a) devida motivação;
b) pertinência temática com o que se investiga;
c) limitação temporal;
d) necessidade absoluta da medida, pois o resultado por apurar não adviria de nenhum outro meio ou fonte lícita de prova."

A exata compreensão dos requisitos necessários para que uma Comissão Parlamentara de Inquérito delibere por determinar a quebra do sigilo bancário, fiscal e 
de dados telefônicos, encontram-se na decisão monocrática do eminente Min. Cezar

Peluzo (MS n. 25812-DF MC), postos em torno seguintes observações:

"A primeira é que se exigem, ao lado dos requisitos da motivação (a) e da pertinência temática com o que se investiga (b), outros de não menor peso. Um deles é a necessidade absoluta da medida (c), no sentido de que o resultado por apurar não possa advir de nenhum outro meio ou fonte lícita de prova. Esta exigência é de justificação meridiana, suscetível de ser entendida por toda a gente, pela razão óbvia de que não se pode sacrificar direito fundamental tutelado pela Constituição - o direito à intimidade -, mediante uso da medida drástica e extrema da quebra de sigilos, quando a existência do fato ou fatos sob investigação pode ser lograda com recurso aos meios ordinários de prova. Restrições absolutas a direito constitucional só se justificam em situações de absoluta excepcionalidade. O outro requisito é a existência de limitação temporal do objeto da medida (d), enquanto predeterminação formal do período que, constituindo a referência do tempo provável em que teria ocorrido o fato investigado, seja suficiente para lhe esclarecer a ocorrência por via tão excepcional e extrema. E é não menos cristalina a racionalidade desta condição decisiva, pois nada legitimaria devassa ilimitada da vida bancária, fiscal e comunicativa do cidadão, debaixo do pretexto de que Comissão Parlamentar de Inquérito precise investigar fato ou fatos específicos, que são sempre situados no tempo, ainda quando de modo só aproximado. Ou seja - para que se não invoque nenhuma dúvida ao propósito -, a Constituição da República não tolera devassa ampla de dados da intimidade do cidadão, quando, para atender a necessidade legítima de investigação de ato ou atos ilícitos que lhe seriam imputáveis, basta seja a quebra de sigilos limitada ao período de tempo em que se teriam passado esses mesmos supostos atos. Que interesse jurídico pode enxergar-se na revelação de dados íntimos de outros períodos? Só a concorrência de todos esses requisitos autoriza, perante a ordem constitucional, à luz do princípio da proporcionalidade, a prevalência do interesse público, encarnado nas deliberações legítimas de CPI, sobre o resguardo da intimidade, enquanto bem jurídico e valor essencial à plenitude da dignidade da pessoa humana."

Trata-se mesmo de medida excepcional que não pode desbordar limites do direito fundamental à privacidade pessoal. Observa o Min. Cezar Peluso que "a jurisprudência firmada pela Corte, ao propósito do alcance da norma prevista no art. $58, \S 3^{\circ}$, da Constituição Federal, já reconheceu a qualquer Comissão Parlamentar de Inquérito o poder de decretar quebra dos sigilos fiscal, bancário e telefônico, desde que o faça em ato devidamente fundamentado, relativo a fatos que, servindo de indício de atividade ilícita ou irregular, revelem a existência de causa provável, apta a legitimar a medida, que guarda manifestíssimo caráter excepcional (MS n. 23.452-RJ, Rel. Min. CELSO 
DE MELLO; MS n. 23.466-DF, Rel. Min. SEPÚlVEDA PERTENCE; MS n. 23.619-DF, Rel. Min. oCTAVIO GALLOTTI; MS n. 23.639-DF, Rel. Min. CELSO DE MELLO; etc.). Não é lícito, pois, a nenhuma delas, como o não é sequer aos juízes mesmos (CF, art. 93, IX), afastar-se dos requisitos constitucionais que resguardam o direito humano fundamental de se opor ao arbítrio do Estado, o qual a ordem jurídica civilizada não autoriza a, sem graves razões, cuja declaração as torne suscetíveis de controle jurisdicional, devassar registros sigilosos alheios, inerentes à esfera da vida privada e da intimidade pessoal”. 


\section{CAP. 3 SISTEMA DE REPARTIÇÃO DE COMPETÊNCIAS ADOTADO NO MODELO FEDERATIVO BRASILEIRO}

Desde logo, há que se registrar o primacial artigo da Constituição Federal proclamando que a República Federativa do Brasil é formada pela união indissolúvel dos Estados e Municípios e do Distrito Federal. Acentue-se, designadamente por repercutir nos pressupostos de nossos estudos, que "a autonomia do Estado-membro constitui elemento essencial à configuração do Estado Federal", assim acentuado por Raul Machado Horta. ${ }^{94}$

A federação, vista como técnica de exercício de poder político, visa a "estabelecer a unidade dentro da diferenciação, ou seja, a união sem prejuízo da diversidade", preconiza Josaphat Marinho. A flexibilidade do sistema federativo "reconhece e protege, concomitantemente, prerrogativas e interesses recíprocos e particulares das entidades autônomas congregadas e da coletividade total, que as abrange e as fiscaliza, como sente a presença delas, nos limites da constituição adotada". ${ }^{95}$

Posto como pilar de sustentação do edifício da Federação, a autonomia dos Estados-membros é aspecto que sedimenta a própria estrutura federal do Estado soberano. Esse pilar enrijece-se pelo reconhecimento de que "os Estados organizam-se e regem-se pelas Constituições e leis que adotarem, observados os princípios desta Constituição" (art. 25, caput). Aos Estados-membros confere-se a capacidade de eles próprios elaborarem suas Constituições Estaduais, diferentemente do Estado Regional italiano e do Estado Autonômico espanhol que atribuem, respectivamente, ao Legislativo nacional a aprovação do Estatuto regional e às Cortes Gerais a aprovação das respectivas Constituições das Comunidades autônomas.

Na Federação brasileira, aos Estados-membros confere-se autonomia para, observados os princípios da Constituição Federal, elaborarem suas próprias Constituições e as leis que os regerão. Há autodeterminação com limites. E por aí se inicia o estreito caminho de modelagem da autonomia dos Estados-membros. Mas, como acentua Tércio Sampaio Ferraz Jr., embora o poder constituinte estadual seja um

\footnotetext{
${ }^{94}$ HORTA, Raul Machado. Direito Constitucional. 3. ed., Belo Horizonte: Del Rey, 2002, p. 361.

95 MARINHO, Josaphat. Poderes remanescentes na federação brasileira. Salvador: Artes Gráficas, 1954, p. 11.
} 
poder decorrente, um poder condicionado, sua competência, "no seu âmbito, goza do atributo da principialidade". 96 A autonomia estadual comporta, pois, resquícios de principialidade. Ou, como analisa Dalmo de Abreu Dallari esse mesmo atributo: “A autonomia tem algo de original na medida em que é, no âmbito territorial de sua competência, princípio de uma ordem. Então, em relação àquele tema, que é de competência estadual, a ordem jurídica começa com o que o Estado dispuser. É o princípio de uma ordem.",97

\subsection{Os Estados-membros na repartição de competências da federação brasileira}

O sistema de repartição de competências adotado pelo modelo federativo brasileiro da Constituição de 1988 é tema que já mereceu aprofundados estudos da doutrina brasileira, sobressaindo-se especialmente o da Dra. Fernanda Dias Menezes de Almeida, com obra clássica, ${ }^{98}$ e referência para juristas e estudiosos do assunto e também para esse nosso estudo, não se olvidando a consideração de outros. ${ }^{99}$

Acerca do sistema de repartição de competências adotado pela Constituição de 1988, "combinação de praticamente tudo o que já se experimentou na prática federativa", no registro de Fernanda Dias Menezes de Almeida, “convivem competências privativas, repartidas horizontalmente, com competências concorrentes, repartidas verticalmente, abrindo-se espaço também para a participação das ordens parciais na esfera de competência próprias da ordem central,

\footnotetext{
${ }^{96}$ Princípios condicionantes do poder constituinte estadual em face da Constituição Federal. In: $R D P$, n. 92 , p. 41.

97 Temas de direito constitucional estadual e questões sobre o pacto federativo. São Paulo: Assembléia Legislativa do Estado de São Paulo, 2004, p.128.

98 Competências na Constituição de 1988. 4. ed., São Paulo: Atlas, 2007.

99 FERREIRA FILHO, Manoel Gonçalves. Comentários à Constituição Brasileira de 1988. São Paulo: Saraiva, 1990, v. 1. Aspectos do direito constitucional contemporâneo. São Paulo: Saraiva, 2003, p. 157-185. SILVA, José Afonso da. Curso de direito constitucional positivo. 5. ed. São Paulo: Revista dos Tribunais, 1989. HORTA, Raul Machado. Direito Constitucional. 3. ed., Belo Horizonte: Del Rey, 2002. BORGES NETTO, André Luiz. Competências Legislativas dos Estados-Membros. São Paulo: Revista dos Tribunais, 1999. LOBO, Paulo Luiz Neto. Competência legislativa concorrente dos Estados-membros na Constituição de 1988. Brasília: Senado Federal. In: Revista de Informação Legislativa, n. 101, jan./mar. 1989, p. 87-104; MORAES, Alexandre. Direito constitucional. 17. ed., São Paulo: Atlas, 2005. MORAES, Alexandre. Constituição do Brasil interpretada e legislação constitucional. 5. ed., São Paulo: Atlas, 2005. SPROESSER, Andyara Klopstock. Processo Legislativo. 2. ed., São Paulo: Alesp/SGP, 2004, p. 52-60. FARIAS, Paulo José Leite. Competência federativa e proteção ambiental. Porto Alegre: Fabris, 1999. ROCHA, Cármen Lúcia Antunes. República e Federação no Brasil: traços constitucionais da organização política brasileira. Belo Horizonte: Del Rey, 1996, p. 236-257.
} 
mediante delegação". ${ }^{100}$ Sob a perspectiva das competências dos Estados-membros, como cada ente federativo recebeu competências próprias, importa, então, acentuar, ainda com a autora:

"Os Estados ficaram, também privativamente, com as competências residuais não enumeradas, nos termos do artigo $25, \S 1^{\circ}$, sendo que em mais dois parágrafos do mesmo artigo e no $\S 4^{\circ}$ do artigo 18 destacaram-se outras competências estaduais privativas: a de explorar os serviços locais de gás canalizado (art. $25, \S 2^{\circ}$ ); a de instituir regiões metropolitanas, aglomerações urbanas e microrregiões (art. $25, \S 3^{\circ}$ ) e a de criar Municípios (art. 18, $\S 4^{\circ}$ ). ${ }^{, 101}$

Mas, não são muitas as matérias atribuídas à competência estadual, por isso mesmo, impõe-se, desde já, o registro do acentuado esvaziamento das competências, tanto as materiais como as legislativas, dos Estados-membros. É o que vem constatado nas fundadas conclusões do exame feito por Fernanda Dias Menezes de Almeida acerca da distribuição de competências na Federação brasileira:

"A análise das competências de cada esfera de poder revela uma clara preponderância do poder federal, um certo fortalecimento do poder municipal e a permanência da situação desconfortável do poder estadual, cujos poderes remanescentes continuaram esvaziados de conteúdo e de significado prático. Com efeito, não se diminuiu, antes se ampliou o extenso rol de competências materiais e legislativas exclusivas da União, muito embora algumas delas, com vantagem, pudessem ser transferidas para o âmbito das competências concorrentes." 102

O sistema de repartição de competências interfere no delineamento dos limites da autonomia dos Estados-membros; é uma autonomia condicionada pelos parâmetros da sistemática de distribuição de competências que, no modelo federativo brasileiro desprestigia estes entes subnacionais, com poderes remanescentes limitados, eis que extenso o campo de poderes enumerados da União. Na competência tributária, contudo, a sistemática se altera e os poderes residuais aí remanescem para a União.

No campo das competências concorrentes, indicado como repartição vertical e que não favorece a independência recíproca dos entes federativos, há atritos que são dirimidos pelo intérprete final e guardião da Constituição, o Supremo Tribunal Federal,

\footnotetext{
${ }^{100}$ Ob. cit., p. 58.

101 Id. ibid.

${ }^{102}$ Competências ... p. 144.
} 
que, como salienta Manoel Gonçalves Ferreira Filho, "tem uma inclinação para entender que a competência, na dúvida, é federal". ${ }^{103}$ Com efeito, robora André Ramos Tavares, constata-se na jurisprudência do Supremo Tribunal Federal "uma tendência pela opção de centralização das competências na União, em vez de um atendimento ao que estabelece o próprio art. 25 que deveria ser a diretriz para a interpretação nos casos de dúvida acerca da competência a quem cabe determinada competência legislativa". ${ }^{104}$

Com foco no princípio da segurança jurídica, Monica Herman Salem Caggiano, adverte que à harmonia federativa "não basta a perspectiva constitucional, ainda que preconizando um adequado equilíbrio entre o Poder Central e os Poderes dos Estados-membros. Impõe-se um balanceamento claro e preciso dos pólos decisionais (Poder Central e Poderes Periféricos), exatamente com o escopo de evitar o conflito ou o exorbitante e excessivo clima de rivalidade" entre os entes federativos. ${ }^{105}$

Referentemente às competências concorrentes repartidas verticalmente, em notório detrimento dos Estados-membros, Monica Caggiano, fundadamente, preconiza os receios de um retorno ao federalismo de integração:

"A engenhosa técnica da partilha concorrente, contudo, foi insuficiente para acalmar as perspectivas das unidades periféricas (dos Estados-membros), como também, a tradicional tendência centralizadora da autoridade federal, ensejando um repertório de dúvidas e debates a alcançar relevantes pontos da esfera das competências que foram partilhadas na verticalidade, abrindo uma significativa brecha à insegurança jurídica.

\section{(...)}

E mais, denota, entre nós, a persistente presença de 'trauma antigo', já identificado pela historiadora Aspásia Camargo, reflexo direto da formação do federalismo doméstico 'de cima para baixo'. Isto, explica a ilustre pesquisadora, implica a continuidade e manutenção de um modelo defeituoso, que ela denomina de 'pacto patrimonial, ...baseado na cumplicidade promíscua entre o poder público centralizado, e o poder privado de origem local', o que impede a real concentração de autonomia das unidades federadas, por mais sofisticada que venha a se afigurar a técnica utilizada para a repartição das competências.

De qualquer forma, o próprio caráter difuso, peculiar à verticalização empregada na partilha de competências pela Carta de

\footnotetext{
${ }^{103}$ FERREIRA FILHO, Manoel Gonçalves. Temas de Direito Constitucional Estadual e questões sobre o Pacto Federativo. São Paulo: Assembléia Legislativa de São Paulo, 2004. p. 160.

104 TAVARES, André Ramos. Temas de Direito Constitucional Estadual e questões sobre o Pacto Federativo. São Paulo: Assembléia Legislativa de São Paulo, 2004. p. 166.

105 Federalismo incompleto, descentralização e indefinição de competências. Revista Direito Mackenzie. São Paulo: Editora Mackenzie, 2000, p. 38.
} 
1988, enseja a abertura de relevantes brechas a ingerências e, notadamente, à interferência do Poder Central, inserindo sérios riscos no tocante ao standard da segurança jurídica, introduzindo um clima de incerteza. Ademais, autoriza, a nosso ver, uma flagrante burla ao princípio federativo, preordenando uma ação centralizadora a reconduzir ao modelo federalista de integração, que dominou o espectro federal brasileiro por quase três décadas."106

\subsection{Delegação de competências}

Concernente à delegação de competências, com precedentes na história constitucional brasileira, ${ }^{107}$ prevista agora no parágrafo único do artigo 22 , lei complementar poderá autorizar os Estados a legislar sobre questões específicas das matérias relacionadas nos vinte e nove incisos deste artigo. Vê-se que todas as matérias discriminadas no extenso rol de incisos do artigo 22 podem ser objeto de delegação ${ }^{108}$, desde que a matéria delegada seja delimitada em seu objeto, isto é, cinjase a questões específicas, para atender a peculiaridades regionais, que, aliás, o próprio constituinte originário, no $\S 3^{\circ}$ do art. 24 , reconhece que há. Por isso mesmo, embora se deva reverência ao princípio da igualdade de tratamento às entidades federadas, indagase se poderia o legislador federal, em homenagem à dissimetria entre os Estados e atendendo a peculiaridades regionais, delegar somente a um ou a alguns ou, deveria delegar necessariamente a todos os Estados competência para legislar sobre matéria privativa da União. Alexandre de Moraes, após acentuar que na delegação devem vir satisfeitos os requisitos formal (lei complementar federal) e material (particularização de questões específicas do elenco das matérias privativas da União), ressalta outro requisito à delegação, o implícito, decorrente do art. 19 da CF: "vedação de criação, por parte de qualquer dos entes federativos, de preferências entre si. Dessa forma, a Lei Complementar editada pela União deverá delegar um ponto específico de sua competência a todos os Estados, sob pena de ferimento do princípio da igualdade

\footnotetext{
${ }^{106}$ Idem, p. 40-41.

107 Constituição de 1937, art. 17: “Nas matérias de competência exclusiva da União, a lei poderá delegar aos Estados a faculdade de legislar, seja para regular a matéria, seja para suprir as lacunas da legislação federal, quando se trate de questão que interesse, de maneira predominante, a um ou alguns Estados. Nesse caso, a lei votada pela Assembléia Estadual só entrará em vigor mediante aprovação do Governo Federal."

108 Fernanda Dias Menezes de Almeida anota ressalva e crítica a essa possibilidade de todas as matérias arroladas nos artigo 22, indiscriminadamente, poderem ser objeto de delegação: “A ressalva diz respeito às matérias dos incisos XI, XXI, XXIV e XXVIII. Em relação a elas entendemos que não se aplica o parágrafo único do artigo 22, uma vez que os Estados legislam por direito próprio sobre questões específicas, sempre que a competência da União se restringe à edição de normas gerais, não dependendo, portanto, de nenhuma delegação." Ob. cit., p. 93.
} 
federativa". ${ }^{109}$ Foi o que fez o legislador federal, ao editar a Lei Complementar n. 103, de 14 de julho de 2000, autorizando "os Estados e o Distrito Federal a instituir o piso salarial a que se refere o inciso $\mathrm{V}$ do art. $7^{\circ}$ da Constituição Federal, por aplicação do disposto no parágrafo único do seu art. 22”. Pelo pioneirismo da lei, transcrevem-se os seus dois artigos:

“Art. $1^{\circ}$ - Os Estados e o Distrito Federal ficam autorizados a instituir, mediante lei de iniciativa do Poder Executivo, o piso salarial de que trata o inciso $\mathrm{V}$ do art. $7^{\circ}$ da Constituição Federal para os empregados que não tenham piso salarial definido em lei federal, convenção ou acordo coletivo de trabalho.

$\S 1^{\circ}$ - A autorização de que trata este artigo não poderá ser exercida:

I - no segundo semestre do ano em que se verificar eleição para os cargos de Governador dos Estados e do Distrito Federal e de Deputados Estaduais e Distritais;

II - em relação à remuneração de servidores públicos municipais.

$\S 2^{\circ}$ - O piso salarial a que se refere o caput poderá ser estendido aos empregados domésticos.

Art. $2^{\circ}$ - Esta Lei Complementar entra em vigor na data de sua publicação."

Decorrente desta específica autorização, no Estado de São Paulo, por exemplo, foram editadas as leis ordinárias n.s 12.640/07 e 12.967/08. Na exposição de motivos do projeto de lei n. 180/08, do qual originou esta última lei, consta: "Trata a presente de proposta legislativa de reajuste dos valores fixados na Lei n. 12.640, de 11 de julho de 2007, que, no âmbito do Estado de São Paulo, instituiu pisos salariais para os trabalhadores que especificou, nos termos da delegacão contida na Lei Complementar $n^{\circ} \mathbf{1 0 3}$, de 14 de julho de 2000, editada nos termos dos artigos $7^{\circ}$, inciso V, e 22, parágrafo único, da Constituição Federal." Também pelo valor histórico, reproduz-se:

“Lei n. 12.967, de 29 de abril de 2008

Revaloriza os pisos salariais mensais dos trabalhadores que especifica, instituídos pela Lei $n$. 12.640, de 11 de julho de 2007.

O GOVERNADOR DO ESTADO DE SÃO PAULO:

Faço saber que a Assembléia Legislativa decreta e eu promulgo a seguinte lei:

Artigo $1^{\circ}$ - O artigo $1^{\circ}$ da Lei n. 12.640, de 11 de julho de 2007, passa a vigorar com a seguinte redação:

" Artigo $1^{\circ}$ - No âmbito do Estado de São Paulo, os pisos salariais mensais dos trabalhadores a seguir indicados ficam fixados em:

\footnotetext{
${ }^{109}$ Constituição do Brasil interpretada. São Paulo: Atlas, 2002, p. 680-681.
} 
I - R\$ 450,00 (quatrocentos e cinqüenta reais), para os trabalhadores domésticos, serventes, trabalhadores agropecuários e florestais, pescadores, contínuos, mensageiros e trabalhadores de serviços de limpeza e conservação, trabalhadores de serviços de manutenção de áreas verdes e de logradouros públicos, auxiliares de serviços gerais de escritório, empregados não-especializados do comércio, da indústria e de serviços administrativos, cumins, "barboys", lavadeiros, ascensoristas, "motoboys", trabalhadores de movimentação e manipulação de mercadorias e materiais e trabalhadores não-especializados de minas e pedreiras;

II - R\$ 475,00 (quatrocentos e setenta e cinco reais), para os operadores de máquinas e implementos agrícolas e florestais, de máquinas da construção civil, de mineração e de cortar e lavrar madeira, classificadores de correspondência e carteiros, tintureiros, barbeiros, cabeleireiros, manicures e pedicures, dedetizadores, vendedores, trabalhadores de costura e estofadores, pedreiros, trabalhadores de preparação de alimentos e bebidas, de fabricação e confecção de papel e papelão, trabalhadores em serviços de proteção e segurança pessoal e patrimonial, trabalhadores de serviços de turismo e hospedagem, garçons, cobradores de transportes coletivos, "barmen", pintores, encanadores, soldadores, chapeadores, montadores de estruturas metálicas, vidreiros e ceramistas, fiandeiros, tecelões, tingidores, trabalhadores de curtimento, joalheiros, ourives, operadores de máquinas de escritório, secretários, datilógrafos, digitadores, telefonistas, operadores de telefone e de "telemarketing", atendentes e comissários de serviços de transporte de passageiros, trabalhadores de redes de energia e de telecomunicações, mestres e contramestres, marceneiros, trabalhadores em usinagem de metais, ajustadores mecânicos, montadores de máquinas, operadores de instalações de processamento químico e supervisores de produção e manutenção industrial;

III - R\$ 505,00 (quinhentos e cinco reais), para os administradores agropecuários e florestais, trabalhadores de serviços de higiene e saúde, chefes de serviços de transportes e de comunicações, supervisores de compras e de vendas, agentes técnicos em vendas e representantes comerciais, operadores de estação de rádio e de estação de televisão, de equipamentos de sonorização e de projeção cinematográfica e técnicos em eletrônica.” (NR)

Artigo $\mathbf{2}^{\mathbf{0}}$ - Esta lei entra em vigor no primeiro dia do mês subseqüente ao da data de sua publicação.

Palácio dos Bandeirantes, 29 de abril de 2008.

JOSÉ SERRA

Guilherme Afif Domingos

Secretário do Emprego e Relações do Trabalho

Aloysio Nunes Ferreira Filho

Secretário-Chefe da Casa Civil”,

Buscando propiciar efetiva flexibilização na distribuição de competências privativas da União mediante delegação aos Estados, outros projetos de lei complementar tramitam no Congresso Nacional. ${ }^{110}$

${ }^{110}$ Na Câmara dos Deputados: PLP n. 272/90; PLP 33/03; PLP 47/03; PLP 136/07 (autoriza os Estados a legislar sobre mobilidade urbana, a partir das diretrizes nacionais que estabelece, conforme prevê o parágrafo único do art. 22 da Constituição Federal).

No Senado: PLS n. 21/2005; PLS 52/2007 (autoriza os Estados e o Distrito Federal a legislar sobre direito penal em questões específicas que define, nos termos do art. 22, parágrafo único, da Constituição Federal). 


\section{3 Área de atuação do legislador estadual}

Prosseguindo na questão da distribuição de competências aos Estadosmembros delineada pela Constituição Federal, Fernanda Dias Menezes de Almeida acentua que "é bastante restrita a área de atuação do legislador estadual" "111 Anota-se que aos Estados, e não mais à União, compete a instituição de regiões metropolitanas; competindo também aos Estados instituir outras unidades regionais, isto é, aglomerações urbanas e microrregiões, constituídas por agrupamentos de municípios limítrofes, para integrar a organização, o planejamento e a execução de funções públicas de interesse comum (art. $25, \S 3^{\circ}$ ). Atribui-se, ainda, aos Estados, a criação de Municípios, mediante lei (art. 18, $\S 4^{\circ}$ ), retornando à esfera federal, por decisão do constituinte derivado, a competência para estabelecer, por lei complementar, os requisitos para criação de Municípios (art. 18, § $4^{\circ}$, com redação da EC n. 15, de 12-996). Embora a criação de distritos dependa ainda dos requisitos estabelecidos por lei estadual, ela se dá por norma municipal. Da mesma forma, compete agora aos próprios Municípios, e não mais aos Estados, a edição de suas próprias Leis Orgânicas.

Referentemente à competência legislativa privativa não enunciada, ainda acompanhando os ensinamentos de Fernanda Dias Menezes de Almeida, "pode-se dizer que os Estados legislam hoje, com exclusividade, apenas sobre os assuntos de sua competência material administrativa e financeira, sempre bastante limitados, principalmente pelas regras de subordinação normativa". ${ }^{112}$ Relaciona-se, então, as matérias de competência do Estado de São Paulo, e.g., seguindo, especialmente, o disposto no artigo 19 de sua Constituição: legislação sobre sistema tributário estadual, instituição de impostos, taxas, contribuições de melhoria e contribuição social; plano plurianual, diretrizes orçamentárias, orçamento anual, operações de crédito, dívida pública e empréstimos externos; servidores públicos do Estado, seu regime jurídico, provimento de cargos, estabilidade e aposentadoria; criação e extinção de cargos, empregos e funções públicas, e fixação de vencimentos e vantagens; autorização para alienação de bens imóveis do Estado ou a cessão de direitos reais a eles relativos, bem como o recebimento, pelo Estado, de doações com encargo; autorização para cessão ou concessão de uso de bens imóveis do Estado a particulares; regime de concessão ou permissão de serviços públicos estaduais; criação e extinção de Secretarias de Estado e

\footnotetext{
${ }^{111}$ Ob. cit., p. 110.

112 Ob. cit., p. 111.
} 
órgãos da administração pública; criação de universidades estaduais; bens do domínio do Estado e proteção do patrimônio público; organização administrativa, organização do Poder Legislativo, do Poder Judiciário, do Ministério Público, da Defensoria Pública, da Procuradoria Geral do Estado, da Procuradoria da Assembléia Legislativa; normas de direito financeiro; fixação ou alteração do efetivo da Polícia Militar, regime jurídico dos militares, provimento de cargos, promoções, estabilidade, remuneração, reforma e transferência para inatividade; legislação penitenciária estadual; criação, alteração ou supressão de cartórios notariais e de registros públicos; normas sobre justiça de paz; sistema integrado de gerenciamento dos recursos hídricos, congregando órgãos estaduais e municipais e a sociedade civil; plano plurianual de saneamento básico; processo de coleta e percurso de sangue no território estadual; criação de fundos, aí incluído o de amparo à pesquisa científica e tecnológica; disciplina do processo de escolha, pela Assembléia Legislativa, do Governador e do ViceGovernador do Estado, nas hipóteses em que se verificar a dupla vacância desses cargos nos últimos dois anos do período governamental.

Além da função legislativa, ao Poder Legislativo estadual, por seus Deputados e Comissões, incumbe, ainda, decidir, quando for o caso, sobre intervenção estadual em Município; autorizar referendo e convocar plebiscito; dar posse ao Governador e ao Vice-Governador eleitos; declarar a perda do mandato do Governador; receber a denúncia e promover o respectivo processo, no caso de crime de responsabilidade do Governador do Estado; destituir o Procurador-Geral de Justiça; tomar e julgar, anualmente, as contas prestadas pelo Governador, pela Mesa da Assembléia Legislativa, pelo Presidente do Tribunal de Justiça e pelo Procurador-Geral de Justiça; apreciar os relatórios sobre execução dos Planos de Governo; fiscalizar e controlar os atos do Poder Executivo, inclusive os da administração descentralizada; sustar os atos normativos do Poder Executivo que exorbitem do poder regulamentar ou dos limites de delegação legislativa, neste caso quando o Estado adota o regime de leis delegadas; suspender, no todo ou em parte, a execução de lei ou ato normativo declarado inconstitucional em decisão irrecorrível do Tribunal de Justiça; solicitar informações ao Governador; requisitar informações aos Secretários de Estado, dirigentes, diretores e Superintendentes de órgãos da administração pública indireta e fundacional, ao Procurador-Geral de Justiça e aos Reitores das universidades públicas estaduais sobre assunto relacionado com sua pasta ou instituição; convocar o 
Procurador-Geral de Justiça, o Procurador-Geral do Estado e o Defensor Público Geral para prestar informações sobre assuntos previamente determinados; convocar Secretários de Estado, dirigentes, diretores e Superintendentes de órgãos da administração pública indireta e fundacional e Reitores de universidades públicas estaduais para prestar, pessoalmente, informações sobre assuntos previamente determinados. Compete, ainda, ao Poder Legislativo Estadual, aprovar três Conselheiros do Tribunal de Contas indicados pelo Governador e escolher e aprovar outros quatro Conselheiros.

\subsection{Autonomia dos Estados-membros e processo legislativo estadual}

Os limites postos à autonomia dos Estados-membros circunscrevem-se, sobretudo, aos princípios que promanam da própria Constituição Federal e às regras de preordenação da organização das unidades federativas, previstas, igualmente, na Constituição Federal.

Princípios são mandamentos nucleares, normas generalíssimas que informam a conformação de determinado tema constitucional, pilares de sustentação de um sistema. ${ }^{113}$

À indagação sobre o que significa, para o constituinte estadual, à luz do disposto no artigo 25 da Constituição Federal, observar os princípios, aí incluídas as regras ou princípios estabelecidos, Tércio Sampaio Ferraz Jr. esclarece:

"Em primeiro lugar, devemos reconhecer que para observar princípios, o constituinte não precisa repeti-los na Constituição Estadual, embora nada impeça de fazê-lo. Observar um princípio significa assim abster-se de emitir regras com ele incompatíveis ou, positivamente, emitir regras constitucionais compatíveis. Não se cumpre um princípio repetindo o seu teor, mas emitindo regras que com ele compõem um conjunto hierarquicamente harmônico. Como princípios não exigem um comportamento específico nem são aplicáveis à maneira de um 'tudo ou nada', observá-los significa seguir-lhes a orientação ao estabelecerem-se regras constitucionais estaduais. Isto confere ao constituinte decorrente uma certa flexibilidade legitimante que faz de sua competência um poder condicionado, mas não limitado.."

${ }^{113}$ GORDILLO, Agustín. Princípios gerais de direito público.São Paulo: Ed. Revista dos Tribunais, 1977. FERREIRA FILHO, Manoel Gonçalves. Aspectos do direito constitucional contemporâneo. São Paulo: Saraiva, 2003. p. 162-163.

${ }^{114}$ Princípios condicionantes..., p. 40. 
Alguns princípios são facilmente identificáveis, vêm expressos na Constituição Federal. Outros, nem tanto, pois implícitos. Àqueles corresponde o preceituado no inciso VII do artigo 34: forma republicana, sistema representativo, regime democrático, direitos da pessoa humana, autonomia municipal, prestação de contas da administração pública, direta e indireta. Evidentemente, também o gizado pela impossibilidade de ser objeto de emenda à Constituição visando a alterar o modelo estabelecido de separação dos Poderes (art. 60, $\S 4^{\circ}$, III) se impõe como princípio expresso. Os demais princípios inabolíveis por emenda constitucional têm correspondência com os já enunciados no artigo 34, VII (art. 60, § $4^{\circ}$, II e IV), ou, então, deixa de ser aplicável, como é o caso da forma federativa de Estado (art. 60, $\S$ $\left.4^{\mathrm{o}}, \mathrm{I}\right)$.

Os princípios implícitos, nas fundadas observações de Manoel Gonçalves Ferreira Filho, "são sempre duvidosos, na medida em que padecem de subjetivismo (pois cada jurista acaba por estabelecer a sua relação de princípios 'implícitos'), o que enfraquece a sua respeitabilidade científica". ${ }^{115}$ Adverte, no entanto, que "esses princípios 'implícitos’ não podem ser invocados como limitadores da autonomia dos Estados". Ainda acompanhando o eminente jurista, "se a Constituição explicitamente enumera limitações, se estas limitações, como exceções que são, devem ser interpretadas restritivamente, é descabido pretender que outros princípios também sejam imperativos para os Estados-membros". ${ }^{116}$ Revela, no entanto, que "não é essa a jurisprudência do Supremo Tribunal Federal, que vem identificando princípios implícitos obrigatórios para os entes federativos na sua organização", notadamente, "em matéria de processo legislativo". 117

Com efeito, em matéria de processo legislativo, o Supremo Tribunal Federal tem entendido que os Estados-membros devem compulsória observância das normas básicas do processo legislativo federal:

"Constitucional - Estado-membro - Processo legislativo. I - A jurisprudência do STF é no sentido da observância compulsória pelos Estados-membros das regras básicas do processo legislativo federal, como, por exemplo, daquelas que dizem respeito à iniciativa reservada $\left(\mathrm{CF}\right.$, art. $\left.63, \S 1^{\circ}\right)$ e com os limites do poder de emenda parlamentar

\footnotetext{
${ }^{115}$ Aspectos do direito constitucional contemporâneo... p. 163.

${ }^{116}$ Idem, p. 163.

${ }^{117}$ Idem, p. 163.
} 
(CF, art. 63). II - Precedentes: ADI n. 822-RS, rel. Min. Sepúlveda Pertence; ADI n. 766 e ADI n. 774, rel. Min. Celso de Mello; ADI n. 582-SP, rel. Min. Néri da Silveira (RTJ 138/76; ADI n. 152-MG, rel. Min. Ilmar Galvão (RTJ 141/355); ADI n. 645-DF, rel. Min. Ilmar Galvão (RTJ 140/457)."118

É o que sublinha Alexandre de Moraes: "o Supremo Tribunal Federal considera as regras básicas de processo legislativo previstas na Constituição Federal como modelos obrigatórios às Constituições Estaduais, declarando que o modelo estruturador do processo legislativo, tal como delineado em seus aspectos fundamentais pela Carta da República, impõe-se, enquanto padrão normativo, de compulsório atendimento, à observância incondicional dos Estados-membros". ${ }^{119}$ Contudo, registre-se, o Supremo Tribunal Federal ainda não evoluiu para uma contundente conclusão de que o processo legislativo estadual deva ser uma réplica do federal. Indica o Supremo que são as regras básicas, as linhas mestras que devem ser observadas.

De fato, a ordem constitucional imediatamente anterior, em manifesto antifederalismo, demarcava: "As disposições constantes desta Constituição ficam incorporadas, no que couber, ao direito constitucional legislado dos Estados." (art. 200) Mais. A modelagem do Estado Federal brasileiro passava pela obrigatória observância de princípios pelos Estados-membros, dentre eles e necessariamente, por expressa disposição, o do processo legislativo (art. 13, III). Agora não mais. À evidência, alguma mudança houve. ${ }^{120}$ A Constituição vigente não mais impõe, de forma expressa, a observância do processo legislativo federal pelo constituinte estadual. Como salienta Alexandre de Moraes, "não está escrito em lugar algum da Constituição que o processo legislativo tem que ser igual". ${ }^{121}$ Ora, o processo legislativo federal, também previsto e disciplinado pela Constituição de 1988, ainda está consubstanciado no texto constitucional, mas agora, quando muito, como princípio implícito, porque assim quis o constituinte de 1988. E, como salientado por Manoel Gonçalves Ferreira Filho, se remanesce como princípio implícito, os Estados-membros não estão obrigados à observância desta implícita limitação à sua própria autonomia. Daí o eminente jurista

\footnotetext{
${ }^{118}$ ADI 1.060-MC/RS, DJ de 23-9-1994.

${ }^{119}$ Direito Constitucional. 21. ed., São Paulo: Atlas, 2007, p. 617.

${ }^{120}$ CASTELLANO, Cláudio Luis Neves. O modelo federal do processo legislativo e sua observância pelos Estados-membros. RDA, abr./jun. 1999. p. 57-63.

${ }^{121}$ Temas de Direito Constitucional Estadual. São Paulo: Assembléia Legislativa de São Paulo, 2004. p. 136.
} 
concluir: "Com efeito, não se atina com a razão de ser a cópia do processo legislativo federal um ‘princípio' obrigatório para os Estados”. ${ }^{122}$

Em conclusão correlata argumenta Anna Cândida da Cunha Ferraz sobre o processo legislativo estadual:

"Uma das limitações outrora impostas ao constituinte estadual era a observância estrita do processo legislativo federal (cf. Ferraz, 1988 b, p.51). Conseqüência dessa imposição consistia no chamado 'fortalecimento do Poder Executivo', cujas acentuadas funções colegislativas representam um modelo acerbamente criticado de relacionamento entre Poderes Legislativo e Executivo no Brasil (cf. Ferreira Filho, 1986, p. 174 e seguintes).

A Constituição de 1988 suprimiu essa limitação. Podem assim os constituintes estaduais disciplinar livremente o processo de elaboração das leis estaduais ou copiar o modelo federal, se tal hes convier, adotando, por exemplo, as mesmas espécies normativas fixadas na CF (artigo 59) ou criando outras. O limite que enfrentarão ao disciplinarem essa função será o respeito aos princípios constitucionais expressos ou implícitos, tais como o 'respeito ao livre exercício de qualquer dos Poderes estaduais' (artigo 34, IV), a observância do 'regime democrático' (artigo 34, VIII, “a”), a garantia da iniciativa legislativa do Tribunal de Justiça (artigo 125) etc.

Ora, a liberdade de o constituinte estadual estabelecer o seu modelo de processo legislativo poderá ter reflexos no equilíbrio e relacionamento entre os poderes e, conseqüentemente, na mecânica da 'separação de poderes'.,"123 (sublinhou-se)

A autonomia dos Estados-membros, para Michel Temer, não implica, à evidência, a mera tarefa de copiar princípios postos pelo constituinte federal. E conclui, igualmente, que o processo legislativo estadual não deva ser uma mera transcrição do federal.

"Possibilidade de autoconstituição.

Os Estados brasileiros têm a possibilidade de autoconstituição, como expresso no art. 25 da CF. Ao se constituírem obedecerão aos princípios estabelecidos na Constituição Nacional. Significa: o constituinte estadual há de obedecer àquela principiologia. Não se trata de mera cópia dos dispositivos constitucionais.

Assim, exemplificativamente, devem prestar obediência ao princípio da fiscalização financeira e orçamentária; ao princípio do processo legislativo. Não quer dizer que a forma da fiscalização

\footnotetext{
${ }^{122}$ Do Processo Legislativo, 6. ed., São Paulo: Saraiva, 2007. p. 255.

${ }^{123}$ União, estado e município na nova Constituição: enfoque jurídico-formal, in A Nova Constituição Paulista; perspectivas. São Paulo: Fundação Prefeito Faria Lima - CEPAM, Fundação do Desenvolvimento Administrativo - FUNDAP, 1989. Textos apresentados no Seminário "Perspectivas para a Nova Constituição Paulista" em 08-12 ago. 1988. p. 61-62.
} 
financeira e orçamentária bem como o processo legislativo sejam transcrição daqueles da União. É preciso que haja no Estado federado um sistema de fiscalização, um sistema do processo legislativo. Sistemas próprios, porém." ${ }^{124}$ (sublinhou-se)

Acerca do Poder Constituinte dos Estados-membros e a observância dos princípios da Constituição Federal, com conclusão sobre a possibilidade de existir um processo legislativo estadual próprio, observa, ainda, Michel Temer:

Trata-se de competência outorgada pela Constituição Federal para que os Estados se auto-organizem. Visa a "institucionalizar coletividades", no dizer de Manoel Gonçalves Ferreira Filho.

Não é, contudo, emanação direta da soberania constituinte. Deriva desta e, por isso, é competência que o constituinte atribui às unidades federadas, subordinando-a a parâmetros determinados. Assim, as Constituições estaduais hão de observar os princípios estabelecidos na Constituição Federal.

Trata-se de obediência a princípios. Não de obediência à literalidade das normas. A Constituição estadual não é mera cópia dos dispositivos da Constituição Federal. Princípio, como antes ressaltamos, amparado em Celso Antônio Bandeira de Mello, é mais do que norma: é alicerce do sistema; é sua viga mestra.

É aos princípios que se subordinam os Estados ao se organizarem. Essa obrigatoriedade de observação dos princípios tem objetivo de assegurar a unidade nacional, a uniformidade jurídica, a fim de que as várias ordens jurídicas parciais (Estados federados) perfaçam a unidade (Estado Federal).

Nesse campo da principiologia, verifica-se a existência de alguns mais amplos e outros mais estritos. Exemplifica-se: é mais amplo e, portanto, permite margem maior de atuação do constituinte estadual o princípio alusivo ao processo legislativo. $O$ que o constituinte nacional determinou foi a existência, na Constituição estadual, de um processo legislativo. Mas este não há de ser necessariamente o da União, até porque é impossível a adoção do mesmo processo, uma vez que o Legislativo da União é bicameral e o dos Estados é unicameral." ${ }^{125}$ (sublinhou-se)

Confirmando a possibilidade de o constituinte estadual delinear um processo legislativo próprio, José Afonso da Silva conclui que "o constituinte estadual, hoje, tem mais autonomia para organizar o processo legislativo, porque a Constituição de 1988 não impôs aos Estados a obrigação de observar o processo legislativo federal nela estruturado". Observa, no entanto, que "é evidente que os princípios básicos do processo legislativo, sem os quais este inexiste, terão que coincidir nas esferas federal,

124 Elementos de Direito Constitucional. São Paulo: Malheiros, 18. ed., 2002. p. 68.

125 Elementos, p. 90. 
estadual e municipal". Acentua, ainda, que "as regras sobre iniciativa legislativa concorrente e exclusiva, sobre emendas e suas limitações, sobre o processo de formação das leis orçamentárias”, devem ser de observância obrigatória pelos Estados. E arrematou seus ensinamentos sobre a matéria anotando: "Cumpre notar que a Constituição de 1988 tendeu a prestigiar a atuação parlamentar no processo legislativo". ${ }^{126}$ Nesse diapasão, em termos comparativos com o ordenamento autoritário anterior, acentuou-se a possibilidade de efetiva atuação parlamentar, pois agora, tirante a notória euforia das conclusões adiante, as "as liberdades [de ir, vir, ficar; de expressão; de manifestação do pensamento; de convicção política e fillosófica] são permitidas", "tem-se liberdade para debater sobre tudo", "não há mais nada proibido", a Assembléia pode "decidir o que ela quer fazer" e pode ser "o que a sociedade desejar que ela seja". ${ }^{127}$ Evidentemente, nos limites das competências e dentro dos contornos da autonomia a ela conferidos pela Constituição no sistema federativo brasileiro.

Em sentido contrário, Luiz Alberto David Araújo e Vidal Serrano Nunes entendem que "os princípios estruturantes da Carta Republicana, como por exemplo, aqueles pertinentes à organização dos poderes e ao processo legislativo, devem ser simetricamente observados pelas ordens estaduais". ${ }^{128}$ Perfilhando semelhante posicionamento, Fabio Alexandre Coelho advoga que "a melhor postura é, sem dúvida, adotar o processo legislativo federal para os Estados-membros e Municípios". ${ }^{129}$ E conclui: "deixar ao livre arbítrio dos Estados o estabelecimento do processo legislativo que bem entenderem é desprezar a simetria entre o processo federal e o dos entes federados $(\ldots) " \cdot{ }^{130}$

Referentemente ao processo legislativo estadual e a usual invocação do princípio da simetria, princípio implícito (gize-se), em ordem a se buscar fundamentar estrita obediência ao federal, recorre-se às luzes da argumentação lógica do eminente jurista, Manoel Gonçalves Ferreira Filho, não "simetristra", ${ }^{131}$ em defesa da autonomia

\footnotetext{
${ }^{126}$ Curso de Direito Constitucional positivo. 5. ed. São Paulo: Ed. Revista dos Tribunais, 1989, p. 527.

${ }^{127}$ Papel histórico do Poder Legislativo e perspectivas de atuação. São Paulo: Assembléia Legislativa, 1999, p. 15.

${ }^{128}$ Curso de Direito Constitucional, 2. ed., São Paulo: Saraiva, 1999, p. 190.

${ }^{129}$ Processo Legislativo. São Paulo: Ed. Juarez de Oliveira, 2007, p. 365.

${ }^{130}$ Idem, p. 366.

131 "Simetrista" - neologismo utilizado pelo Ministro Aliomar Baleeiro durante debates da Representação n. 864/GB, julgada em 11 de abril de 1973, por ele relatada. Anota José Levi Mello do Amaral Júnior que "durante os debates, o Ministro Baleeiro chamou o Ministro Thompson Flores de "simetrista", e completou: "Não tenho esta tendência."
} 
dos Estados-membros, face às tantas limitações explícitas predeterminadas pela Constituição Federal. De se frisar novamente: “Tais princípios 'implícitos', na verdade, são sempre duvidosos, na medida em que padecem de subjetivismo (pois cada jurista acaba por estabelecer a sua relação de princípios 'implícitos'), o que enfraquece a sua respeitabilidade científica”. ${ }^{132}$ E sua advertência: “esses princípios 'implícitos' não podem ser invocados como limitadores da autonomia dos Estados. Se a Constituição explicitamente enumera limitações, se estas limitações, como exceções que são, devem ser interpretadas restritivamente, é descabido pretender que outros princípios também sejam imperativos para os Estados-membros", 133

O princípio da simetria diz respeito à obrigatoriedade de os Estadosmembros observarem um determinado paradigma, um modelo ou um padrão, decorrente de preceitos constitucionais federais postos, quando dimensiona sua competência de auto-organização.

Ao registrar, por temas, a memória jurisprudencial do Ministro Aliomar Baleeiro, José Levi Mello do Amaral Júnior abre item intitulado "Federalismo princípio da simetria". ${ }^{134}$ Anota que "a Constituição de 1967, seja em seu texto originário (art. $188^{135}$ ), seja na redação da Emenda Constitucional n. 1, de 1969 (art. $200^{136}$ ), impunha aos Estados a incorporação das suas normas ao direito constitucional estadual. Essa determinação constitucional pretérita, que em muito enfraquecia o federalismo brasileiro, foi denominada 'princípio da simetria"”. E extrai de julgados do Ministro Aliomar Baleeiro documentação comprobatória de uma crítica contundente à simetria determinada pelo constituinte federal, que enfraquecia sobremaneira os Estados-membros:

"Para mim, uma Carta Política de Estado-membro só viola a Constituição Federal quando, expressa ou implicitamente, desafia

AMARAL JÚNIOR, José Levi Mello do. Memória jurisprudencial: Ministro Aliomar Baleeiro. Brasília: Supremo Tribunal Federal, 2006, p. 101.

${ }^{132}$ Aspectos do direito constitucional contemporâneo... p. 163.

${ }^{133}$ Idem, p. 163.

134 AMARAL JÚNIOR, José Levi Mello do. Memória jurisprudencial: Ministro Aliomar Baleeiro. Brasília: Supremo Tribunal Federal, 2006, p. 100-106.

135 “Art. 188 - Os Estados reformarão suas Constituições dentro em sessenta dias, para adaptá-las, no que couber, às normas desta Constituição, as quais, findo esse prazo, considerar-se-ão incorporadas automaticamente às cartas estaduais."

136 “Art. 200 - As disposições constantes desta Constituição ficam incorporadas, no que couber, ao Direito Constitucional legislado dos Estados." 
dispositivo desta última ou alguns dos princípios cardeais do regime. Se pensarmos o contrário, melhor seria que o Congresso Nacional incumbisse o Ministério da Justiça, ou o do Interior, ou mesmo o Dasp, de redigir e imprimir uma Constituição-modelo, ou padrão, que os Deputados estaduais preencheriam com o nome do Estado, datariam e assinariam. Na pior hipótese, poupar-se-ia o tempo por demais escasso da Procuradoria-Geral da República e o nosso." (Representação n. 864/GB, julgada em 11 de abril de 1973.)

“(...) a mim me parece que a Constituição estadual, pelo regime que está em vigor hoje no país, tem que ser, como aqui se decretou várias vezes, com meu voto contrário, uma cópia-carbono da Federal." (RE n. 71.016/PR, julgado em 19 de setembro de 1974.)

"Com a vênia de tão esmagadora maioria, não recebo a representação. Creio que o figurino não é tão apertado, tão rígido que não permita pequenas variações em quantidade, largura e colorido. Acho que seria lícito ao Estado estabelecer um quorum menor." (Representação n. 826/MT, julgada em 21 de outubro de 1970.)

"Acredito que a Constituição não deve ser levada a esse extremo de se exigir dos Estados quase que uma verdadeira cópia xerox da Constituição Federal." (Representação n. 898/RS, julgada em 25 de abril de 1974.)

"Diante de duas interpretações perfeitamente possíveis (...) prefiro a que resguarda o princípio fundamental da Constituição, que é o da existência de um regime federativo neste país." (Representação n. 796/SP, julgada em 10 de junho de 1970.)

E arremata José Levi Mello do Amaral Júnior acerca do tema: “Ainda hoje, sob texto constitucional que não mais impõe simetria aos Estados, vez ou outra são proferidas decisões judiciais, como que por inércia, declarando a inconstitucionalidade de dispositivos constitucionais estaduais ao argumento de que se afastam do paradigma federal". 137

Ao que se propõe esse estudo apontar, impende registrar, no entanto, o prestígio que a autonomia dos Estados-membros vem obtendo nos, quase sempre, votos minoritários do Ministro Menezes Direito, quando em debate o modelo de repartição de competências adotado no federalismo brasileiro:

"Não me parece compatível, no estado atual da federacão, que nós mantenhamos uma interpretação tão estreita com relação à vinculação entre o papel dos constituintes estaduais e o papel do

${ }^{137}$ Memória jurisprudencial, ob. cit., p. 106. 
constituinte federal. Pelo contrário, ao meu sentir, é extremamente salutar que isso ocorra. O constituinte estadual e o legislador estadual podem e devem necessariamente estabelecer prazos para que seus órgãos possam julgar processos ou adotar procedimentos que encurtem o tempo de duração; pois até mesmo o constituinte federal introduziu a rápida duração dos processos como uma garantia fundamental."138

${ }^{138}$ Cf. www.jus.br Notícias STF. Supremo entende que estado de SC não tem autonomia para extinguir crédito tributário. Edição de 4 ago. 2008. 


\section{CAP. 4 O PROCESSO LEGISLATIVO COMO INSTRUMENTO PARA CONSECUÇÃO DAS FUNÇÕES DO PODER LEGISLATIVO NO DIREITO CONSTITUCIONǍL BRASILEIRO}

\subsection{As funções do Poder Legislativo}

Para se chegar às funções do Poder Legislativo há que se passar pela separação dos poderes, a qual defluiu do poder político, que se há de entender como aquele que "assume a gestão dos interesses gerais da sociedade. Político, portanto, no sentido etimológico do termo, isto é, relativo à polis, aos negócios públicos, ao bem geral". ${ }^{139}$ Caracteriza-se o poder político estatal como poder soberano, uno e indivisível. Se uno e indivisível, “como falar-se na divisão desse poder em poderes?"140

A teoria da 'separação de poderes' de Montesquieu, fundamenta-se na distinção das funções exercidas pelo poder político. De fato, buscava o filósofo francês, que nos deixou esse legado, um arranjo para conter o arbítrio de quem exerce o poder: "A experiência eterna mostra que todo homem que tem poder é tentado a abusar dele; vai até onde encontra limites. Quem o diria! A própria virtude tem necessidade de limites. Para que não se possa abusar do poder é preciso que, pela disposição das coisas, o poder freie o poder". ${ }^{141} \mathrm{E}$, ao engendrar a disposição das coisas, concebeu um sistema de freios e contrapesos, assim depois referido por Hamilton, Jay e Madison n' $O$ Federalista ${ }^{142}$, mediante atribuição do poder político uno a órgãos diferentes das funções legislativa, executiva e judiciária, sem descurar da liberdade do indivíduo. Essa concepção da separação de poderes incorporar-se-á ao ideário liberal da Revolução Americana e ao da Francesa, e constará da primeira Constituição escrita, a dos Estados Unidos da América, em 1787, irradiando-se também como estruturação do Estado constitucional, fundado, outrossim, na democracia representativa, que tinha como um dos seus pilares de sustentação o mandato parlamentar.

A partir do século XVIII, a preeminência do Legislativo decorria, então, do prestígio da lei. E a lei como expressão da vontade geral, aprovada pelos representantes

\footnotetext{
139 ALMEIDA. Fernanda Dias Menezes de. O Poder Legislativo e suas atribuições no Estado contemporâneo. In: Revista Jurídica 9 de Julho. São Paulo: Alesp, n. 2, 2003, p. 213.

${ }^{140}$ Idem, p. 214.

141 MONTESQUIEU, Charles-Louis de Secondat. Do espírito das leis. Trad. Fernando Henrique Cardoso e Leôncio Martins Rodrigues. São Paulo: Ed. Abril, 1973. p. 156.

${ }^{142}$ HAMILTON, Alexander; MADISON, James; JAY, John. O Federalista. Trad. Reggy Zacconi de Moraes, Rio de Janeiro: Nacional de Direito, 1959, n. 51. p. 209-212.
} 
do povo no Legislativo, e indissociável do conteúdo de justiça, justamente por ser fruto da razão humana e da vontade geral. ${ }^{143}$

Todavia, a primordial função legislativa que, pela separação de poderes punha-se como exclusiva do Legislativo, por uma série de fatores que não se vai aqui enumerar, acaba por restar apenas predominante ${ }^{144}$, pois o Judiciário e, notadamente, o Executivo dela também passam a dispor.

Malgrado tenha havido acentuado desalojamento de sua função precípua, o Poder Legislativo ainda não foi destituído da função de legislar que, aliás, não foi a primeira a ser conquistada; precedeu-a a função de aprovar a tributação. Como salienta Woodrow Wilson:

"Foi tão-somente mediante processo mui vagaroso e indireto que as assembléias de representantes, ou pelos a assembléia de representantes ingleses, modelo de todas as demais, chegou a possuir ou exercer o direito de fazer leis. Passaram-se muitas gerações antes de supor-se tivesse o Parlamento algo a ver com as leis, senão dar-lhes assentimento ou retirá-lo quando novas leis lhe eram submetidas pelo rei." $" 145$

Conquistou também o Parlamento a função de fiscalização e controle dos atos do Executivo.

Várias são, ainda, as funções do Parlamento, como salienta Maurizio Cotta:

"Do ponto de vista funcional, os Parlamentos são instituições geralmente polivantes. A variedade de funções desempenhadas tem uma explicação no papel característico dos Parlamentos, que faz delas os instrumentos políticos do princípio da soberania popular. É deste papel que nasce para o Parlamento o direito e o dever de intervir, embora de formas diversas, em todos os estágios do processo político. Segundo o estágio e as modalidades de tal intervenção, haverá atividades de estímulo e de iniciativa legislativa, de discussão e de deliberação, de inquérito e de controle, de apoio e de legitimação. Tão variadas atividades podem ser englobadamente compreendidas no quadro das quatro funções parlamentares fundamentais: representação, legislação, controle do Executivo e legitimação. É natural que, conforme a posição que cada Parlamento ocupa no sistema político, varie a importância das diversas funções; certamente há

\footnotetext{
${ }^{143}$ FERREIRA FILHO, Manoel Gonçalves. Do processo legislativo. 6 ${ }^{\mathrm{a}}$ ed. São Paulo: Saraiva, 2007, p. 19-77.

144 Alexandre de Moraes salienta que "cada um dos Poderes possui uma função predominante, que o caracteriza como detentor de parcela da soberania estatal, além de outras funções previstas no texto constitucional. São as chamadas funções típicas e atípicas.” Direito constitucional. 21. ed. São Paulo: Atlas, 2007. p. 391.

145 Governo constitucional nos Estados Unidos. Tradução de E. Jacy Monteiro. São Paulo: Ibrasa, 1963. p. 11.
} 
funções que, em determinadas situações políticas, podem se atrofiar e ficar reduzidas ao simples aspecto formal.

Dentre as funções parlamentares, é a representativa a que possui uma posição que poderíamos chamar preliminar. Isso porque, em primeiro lugar, ela é uma constante histórica em meio das transformações sofridas pelas atribuições do Parlamento, e, em segundo lugar, porque nela se baseiam todas as demais funções parlamentares, cujas características dependem, em boa parte, das formas do seu desenvolvimento. Por ser fundamental, esta função assume um significado discriminante entre um Parlamento e outro. Todas as demais atividades parlamentares estão estreitamente ligadas à função representativa: elas são, na realidade, os instrumentos da sua atuação." 146

Da função representativa do Poder Legislativo, todas as demais são ancilares.

A função deliberativa, e.g., operacionaliza a função representativa, dandolhe efetividade. Com efeito, instrumentalizados pelo voto os representantes legislam, judicam (condenam ou absolvem autoridades no impeachment), impõem tributação, decidem investigações, aprovam políticas públicas etc.

Alude-se, ainda, à função de aprovação ou rejeição das indicações de magistrados para composição dos Tribunais Superiores; à de eleger o Presidente e o Vice-Presidente da República na hipótese de dupla vacância, da mesma forma à Assembléia Legislativa incumbe eleger o Governador do Estado.

Essas funções todas, e notadamente a legislativa, efetivam-se por alguma das proposições (proposta de emenda à Constituição, projeto de lei complementar, projeto de lei ordinária, lei delegada, medida provisória, decreto legislativo, resolução) previstas no processo legislativo por norma constitucional ou, no caso de moção e indicação, prevista por norma regimental; é o que se verá adiante.

\subsection{Fundamentos e pressupostos do processo legislativo}

O processo legislativo federal insere-se como tema de extração constitucional. Fundamenta-se na Constituição Federal. Da mesma forma, o processo legislativo estadual, vem expressamente referido no $\S 4^{\circ}$ do seu art. 27. Na Constituição Federal é que se encontram os órgãos incumbidos da legiferação; a matéria legislativa,

146 COTTA, Maurizio. Parlamento. In: BOBBIO, Norberto; MATTEUCCI, Nicola; PASQUINO, Gianfranco. Dicionário de política. 5. ed. São Paulo: Imprensa Oficial do Estado, 2000, p. 883-884. 
os titulares de sua iniciativa, a discussão, revisão, votação e aprovação ou rejeição, o veto e, ainda, o procedimento na elaboração das leis, acentua José Afonso da Silva, observando também que "no que tange à parte dinâmica do processo legislativo aquela que trataremos sob o nome de procedimento legislativo - além de alguns princípios estabelecidos na Constituição - seus fundamentos jurídicos encontram-se nos regimentos internos do Congresso". ${ }^{147}$ No âmbito dos Estados-membros, é na Constituição Federal, igualmente, que se vai haurir quais são os órgãos incumbidos da legislação e da sistemática de competência das matérias legislativas conferidas aos Estados Federados; mas a própria matéria legislativa, os titulares de sua iniciativa, a discussão, revisão, votação e aprovação ou rejeição, o veto e, ainda, o procedimento na formação das leis, além da Constituição Federal, as Constituições Estaduais e os Regimentos Internos das Assembléias Legislativas fornecem, também, outros fundamentos para composição desses elementos essenciais ao processo legislativo.

Acompanhando, ainda, José Afonso da Silva, salienta-se que os pressupostos gerais do processo de formação das leis assentam-se na: “a) existência de Parlamento; b) proposição legislativa; c) competência legislativa do Parlamento; d) capacidade do proponente”. ${ }^{148} \mathrm{O}$ primeiro pressuposto vincula-se ao princípio da separação de poderes, à existência de Congresso, Assembléia, isto é, de um órgão previsto constitucionalmente incumbido da função legislativa com preponderância, pois na divisão de poderes, os outros também a exercem. O segundo pressuposto do processo legislativo diz respeito à existência de "proposição legislativa, devidamente fundamentada por justificação escrita ou oral; não haverá processo legislativo sem proponente". ${ }^{149}$ De modo que a proposição legislativa pressupõe competência de iniciativa legislativa de algum titular que, mediante ato (projeto de lei, projeto de resolução, projeto de decreto legislativo), dirige-se à Casa Legislativa invocando que ela efetive atividade com o fim de ver transformada a proposição em ato legislativo (lei, resolução, decreto legislativo). Como terceiro pressuposto alude-se à competência legislativa; trata-se de saber, num Estado federativo como o Brasil, "a que Legislativo (da União, de Estado, do Distrito Federal, ou de Município) a Constituição atribui competência para receber, processar e deliberar sobre a matéria do projeto que se quer

\footnotetext{
${ }^{147}$ Processo constitucional de formação das leis. 2. ed., São Paulo: Malheiros, 2006, 148 Ob. cit., p. 50.

${ }^{149}$ Idem, p. 49.
} 
apresentar". ${ }^{150}$ E o quarto refere-se à capacidade legislativa do proponente, à titularidade da iniciativa legislativa outorgada constitucionalmente aos que estiverem no exercício de mandato eletivo, parlamentar ou governamental, da cidadania, da presidência de Tribunal ou da chefia do respectivo Ministério Público.

\subsection{Princípios do procedimento legislativo}

Como princípios do processo legislativo, José Afonso da Silva destaca: “a) o da publicidade; $b$ ) o da oralidade; $c$ ) o da separação da discussão e votação; $d$ ) o da unidade da legislatura; e e) o do exame prévio dos projetos por comissões parlamentares". ${ }^{151}$ Ressalta, contudo, que, como fazem parte do aspecto dinâmico do processo, prefere a denominação de princípios do procedimento legislativo.

\subsubsection{Princípio da publicidade}

Na esfera pública, imperiosa se faz a publicidade. Norberto Bobbio acentua: "o que vale nos negócios públicos de um regime democrático é a publicidade como regra, o segredo é a exceção". ${ }^{152}$ Nos dias atuais, mais do que antes, se dá efetividade ao princípio democrático e republicano da publicidade.

Deveras, já não se dispõe apenas de um Diário Oficial para publicação dos atos legislativos, muito embora seja ainda por ele que se dê a publicidade oficial desses atos. Os trabalhos legislativos, nas Comissões ou em Plenário, podem ser acompanhados em tempo real, seja por transmissão de $\mathrm{TV}^{153}$ ou pela Internet, TV-web e Rádio-web. As publicações oficiais das Assembléias Legislativas continuam veiculando a íntegra das sessões, após apanhamento dos debates por taquígrafos e o seu

\footnotetext{
${ }^{150}$ SPROESSER, Andyara Klopstock. 2. ed., São Paulo: ALESP/SGP, 2004, p. 52.

${ }^{151}$ Processo constitucional de formação das leis. 2. ed., São Paulo: Malheiros, 2006, p. 50.

152 Teoria Geral da Política: a filosofia política e as lições dos clássicos. Tradução Daniela Beccaccia Versiani. Rio de Janeiro: Campus, 2000, p. 414.

${ }^{153}$ A Lei federal n. 8.977, de 6 de janeiro de 1995, que dispõe sobre o serviço de TV a Cabo (Lei de Cabodifusão), estabelece que a operadora de TV a Cabo, na sua área de prestação de serviço, deverá tornar disponível, também, um Canal Legislativo estadual/municipal, reservado para o uso compartilhado entre as Assembléias Legislativas e as Câmaras Municipais localizadas nos Municípios da área de prestação de serviço (art. $23, \mathrm{I}, b$ ), sendo o canal voltado para a documentação dos trabalhos parlamentares, especialmente a transmissão ao vivo das sessões.

Além do canal por assinatura, as Assembléias pleiteiam também um canal aberto. Mediante convênio com a TV da Câmara dos Deputados, a Assembléia Legislativa de São Paulo foi pioneira em transmitir seus trabalhos em sinal digital aberto, também, a partir de 20 de agosto de 2008.
} 
inteiro teor fica, também, disponível na Internet, vez que todas as vinte e seis Assembléias Legislativas têm seu próprio sítio na rede mundial de computadores. ${ }^{154}$

O princípio da publicidade, entretanto, padece de mal que não corresponde às suas expectativas: as sessões secretas. Todavia, o constituinte paulista de 1989 , tornando efetiva a exigência democrática da transparência na esfera pública, preceituou para as sessões plenárias realizadas na Assembléia Legislativa uma condição intransponível, que sejam públicas. Trata-se de mandamento constitucional, de maneira que o legislador regimental consolidou as normas atinentes às sessões legislativas sem a possibilidade de prevê-las secretas, em nenhuma hipótese. A Assembléia Legislativa funciona somente em sessões públicas, determina o artigo 10 da Constituição paulista. As sessões só podem ser públicas, ao contrário do que ocorre na Câmara dos Deputados ou no Senado que, dependendo da matéria apreciada, admite ainda sessões secretas.

\subsubsection{Princípio da oralidade}

Pelo princípio da oralidade, os discursos e os debates parlamentares são proferidos de viva voz, não sendo de se deferir, em ordem a sua observância, requerimento escrito de parlamentar para dar, como se lido fosse por ele, na sessão, discurso anexo ao requerimento. Essa prática não corresponderia à verdade dos fatos. Com efeito, como poderia, nos registros taquigráficos e na publicação oficial da íntegra dos debates, constar um parlamentar que não versara assunto algum na sessão, tampouco a ela comparecera, tendo tão-só remetido discurso para ser dado como lido?

Nas votações, quando ostensivas, efetiva-se, também, o princípio da oralidade pelo registro pessoal do voto, de viva voz; mas há nas Casas Legislativas Estaduais, cada vez mais constante, painel eletrônico como meio para cada parlamentar consignar o seu personalíssimo voto.

\subsubsection{Princípio da separação da discussão e votação}

\footnotetext{
${ }^{154}$ Veja-se, por exemplo, vinculado ao Senado Federal, o portal da "COMUNIDADE VIRTUAL DO PODER LEGISLATIVO”, em www.interlegis.gov.br ; bem como todos os sites das Assembléias Legislativas: Acre: www.aleac.ac.gov.br; Alagoas: www.ale.al.gov.br; Amapá: www.al.ap.gov.br; Amazonas: www.aleam.gov.br; Bahia: www.al.ba.gov.br; Ceará: www.al.ce.gov.br; Espírito Santo: www.al.es.gov.br; Goiás: www.assembleia.go.gov.br; Maranhão: www.al.ma.gov.br; Mato Grosso: www.al.mt.gov.br; Mato Grosso do Sul: www.al.ms.gov.br; Minas Gerais: www.almg.gov.br; Pará: www.alepa.pa.gov.br; Paraíba: www.al.pb.gov.br; Paraná: www.alep.pr.gov.br; Pernambuco: www.alepe.pe.gov.br; Piauí: www.alepi.pi.gov.br; Rio de Janeiro: www.alerj.rj.gov.br; Rio Grande do Norte: www.al.rn.gov.br; Rio Grande do Sul: www.al.rs.gov.br; Rondônia: www.ale.ro.gov.br; Roraima: www.al.rr.gov.br; Santa Catarina: www.alesc.sc.gov.br; São Paulo: www.al.sp.gov.br ; Sergipe: www.al.se.gov.br; Tocantins: www.al.to.gov.br.
} 
O princípio da separação da discussão e votação tem por escopo determinar, obviamente, que, por primeiro, faz-se a discussão da propositura e, ao depois, encerrada a discussão, procede-se à votação, não se admitindo retorno à subfase da discussão depois de declarado o seu encerramento.

\subsubsection{Princípio da unidade da legislatura}

As Assembléias Legislativas, em virtude de uma das limitações impostas aos Estados-membros referentemente a sua auto-organização, já têm definido, como norma de pré-ordenação institucional, a duração do mandato dos Deputados Estaduais, quatro anos; ipso facto, cada legislatura, que corresponde à duração do mandato dos membros das Assembléias Legislativas, inicia-se nas datas fixadas pelas respectivas Constituições Estaduais, variando, pois, de um Estado para outro, mas sempre entre $1^{\circ}$ de fevereiro e 15 de março, e termina depois de decorridos quatro anos. Em cada legislatura há incumbências específicas e diferentes composições de seus órgãos, notadamente do Plenário e das comissões. Bem por isso, presumivelmente distintos os compromissos e as propostas da nova legislatura em relação à anterior, eleita sob novos influxos para representar conjunto também diferente de eleitores, com outras expectativas advindas da Representação. Daí normas regimentais fulminando com o arquivamento as proposições de iniciativa parlamentar da legislatura passada, em qualquer fase da tramitação (ou excetuando alguma condição), ressalvando-se, em regra, as de autoria do Executivo, dos Tribunais, do Ministério Público e dos cidadãos.

Em virtude da pertinência com o assunto ora tratado, roborando o acima exposto e acrescentando outros argumentos, transcrevem-se excertos de resposta a Questão de Ordem:

“(...) Na Questão de Ordem, Sua Excelência embasa seu raciocínio no fato de o requerimento ser uma espécie do gênero proposição, conforme disposto no artigo 133, inciso I, alínea "g" do Regimento Interno. A partir dessa premissa - de ser uma proposição-, o requerimento de CPI não estaria atingido pela regra do artigo 177:

“Artigo 177 - Serão arquivadas, no início de cada legislatura, as proposições apresentadas na anterior. Se dependerem de parecer, desde que sem ele ou que lhes seja contrário”.

Ora, argumentou Sua Excelência, como não dependem de qualquer parecer, entendemos, s.m.j., que os Requerimentos de CPI não podem ser arquivados de uma Legislatura para outra, pois não se 
encontram inseridos nas hipóteses previstas no artigo 177 do Regimento Interno.

No entanto, há que se esclarecer que, na hipótese de uma proposição independer de parecer, como é o caso do requerimento de constituição de CPI, seria ela arquivada de qualquer forma por força do estatuído na primeira parte do artigo 177: "Serão arquivadas, no início de cada legislatura, as proposiçôes apresentadas na anterior."

Anote-se, ainda, que a Comissão Parlamentar de Inquérito é Comissão temporária, extingue-se quando preenchido o fim a que se destina, ou com transcorrer o término da legislatura (artigo 25, II, do Regimento Interno).

Outro não é o entendimento do Supremo Tribunal Federal (HC 71.261, Rel. Min. Sepúlveda Pertence) sobre essa questão, eis que julgou recepcionado o $\S 2^{\circ}$ do artigo $5^{\circ}$ da Lei Federal n. 1579/52:

"A duração do inquérito parlamentar - com poder coercitivo sobre particulares, inerente à sua atividade instrutória e a exposição da honra e da imagem das pessoas a desconfianças $e$ conjecturas injuriosas - é um dos pontos de tensão dialética entre a CPI e os direitos individuais, cuja solução, pela limitação temporal do funcionamento do órgão, antes se deve entender matéria apropriada à lei do que aos regimentos: donde a recepcão do art. $5^{\circ}$, \& $2^{\circ}$, da Lei 1.579/52, que situa, no termo final de legislatura em que constituída, o limite intransponível de duração, ao qual, com ou sem prorrogação do prazo inicialmente fixado, se há de restringir a atividade de qualquer comissão parlamentar de inquérito. A disciplina da mesma matéria pelo regimento interno diz apenas com as conveniências de administração parlamentar, das quais cada câmara é o juiz exclusivo, e da qual, por isso - desde que respeitado o limite máximo fixado em lei, o fim da legislatura em curso -, não decorrem direitos para terceiros, nem a legitimação para questionar em juízo sobre a interpretação que lhe dê a Casa do Congresso Nacional."

Portanto, mesmo que uma CPI tivesse sido criada e instalada na legislatura anterior, ela já estaria extinta, nesse momento, em virtude do término da legislatura em que ela (a CPI) se iniciou. Ora, se a própria CPI se extingue com o fim da legislatura, o que não dizer dos requerimentos para a sua constituição, apresentados em legislaturas anteriores? Tais requerimentos, rigorosamente, não subsistem de uma legislatura para outra. $\mathrm{Na}$ esteira desse entendimento tem-se procedido nesta Casa Legislativa, mediante arquivamento, na legislatura que se inicia, dos requerimentos de CPI apresentados na legislatura anterior.

Ad argumentandum, lapidares as palavras do então Presidente da Câmara dos Deputados, Dep. João Paulo Cunha, em resposta, dia 2002-2003, a uma questão de ordem sobre o assunto: 
"Os Parlamentares que tomam posse na nova Legislatura não podem estar compelidos a acatar a expressão das forças políticas da Legislatura anterior, ingressando no mandato já obrigados a constituir a CPI decorrente de requerimento arquivado. Se, entretanto, resolvem os novos Parlamentares pela constituição da Comissão, resta assim atendido o requisito constitucional, desde que um terço dos novos membros da Casa subscrevam o requerimento da criação."

Nesse sentido, ainda, a lição do Ministro CELSO DE MELLO no Mandado de Segurança n. 22.858:

"Decisão: Revela-se incensurável o parecer da douta Procuradoria-Geral da República (fls. 102/114), especialmente no ponto em que demonstra, com apoio no princípio da unidade da legislatura, que o encerramento desse quatriênio legislativo (CF, art. 44, parágrafo único), em cujo âmbito veio a ser formulado o requerimento de abertura de investigação parlamentar, faz instaurar típica hipótese de prejudicialidade da ação mandamental, por efeito de perda superveniente de objeto (fls. 106/107):

'A superveniência do término da legislatura a que se referia o requerimento da instalação de CPI, portanto, prejudica o objeto do writ. A legislatura é nova, diferentes também são os atuais membros da Casa Legislativa e nem todos os impetrantes lograram reeleger-se Deputados. O Judiciário não pode impor à atual legislatura, não mais constituída pelos Deputados subscritores do pedido da CPI, que a instale agora e promova os pertinentes trabalhos. A CPI, como sabido, constitui ato de natureza política e está intimamente ligada à prática de deliberação interna corporis e, na hipótese de a Câmara dos Deputados entendê-la necessária, colhendo a assinatura dos atuais Deputados com o quorum legal, nada impede que a instale."

Esta Presidência entende, em conclusão sobre este ponto da Questão de Ordem, que, como preceituado no $\S 2^{\circ}$ do art. $5^{\circ}$, da Lei Federal n. 1.579, de 18 de março de 1952, as Comissões Parlamentares de Inquérito funcionam "DENTRO DA LEGISLATURA" em que são constituídas; da mesma maneira, a validade e eficácia dos Requerimentos de constituição de CPI cingemse à legislatura em que são apresentados. Daí porque, iniciando-se nova legislatura, como é o caso, impõe-se o imediato arquivamento de tais Requerimentos, a teor, inclusive, do disposto na primeira parte do artigo 177 do Regimento Interno: - Serão arquivadas, no início de cada legislatura, as proposições apresentadas na anterior." 155

${ }^{155}$ Questão de Ordem n. 243, respondida pelo Presidente da Alesp, Dep. Vaz de Lima, na $18^{\text {a }}$ sessão extraordinária, em 11-07-07, publicada no Diário Oficial do Estado - Poder Legislativo, edição de 28-07, p. 51 (colunas 3 e 4) e p.52 (coluna 1). 


\title{
4.3.5 Princípio do exame prévio do projeto por comissões parlamentares
}

A Constituição Federal de 1967, com a redação dada pela Emenda Constitucional n. 1, de 17 de outubro de 1969, expressamente determinava que fosse tido como rejeitado o projeto de lei que recebesse, quanto ao mérito, parecer contrário de todas as Comissões para as quais houvera sido distribuído (art. 58, $\S 2^{\circ}$ ). A atual Carta da República estabelece, como reserva de Regimento Interno, as atribuições das Comissões parlamentares, concedendo-lhes, inclusive, também na forma que dispuser o Regimento Interno, a competência para, em sede deliberante, discutir e votar projetos de lei. Discutem e votam conclusivamente; mas, no âmbito das Comissões, as proposições, em regra, para observância a preceitos regimentais, recebem pareceres opinativos acerca da sua legalidade, juridicidade e constitucionalidade; havendo casos, no entanto, em que os pareceres exarados também consideram o mérito das proposições. No mérito, salienta Andyara Klopstock Sproesser, as Comissões falam sobre a conveniência, a oportunidade e a justiça da medida consubstanciada no projeto:

\begin{abstract}
"A conveniência resulta da necessidade ou utilidade da medida em face do interesse público, da sociedade e dos indivíduos que a compõem. A oportunidade, por sua vez, diz respeito à adequação da medida ao tempo em que deva ser adotada. A justiça, por fim, prende-se à compatibilidade da medida, especificamente, com o valor do Justo. Esse aspecto da justiça, sem dúvida, diz respeito ao bemcomum, que, na verdade, não se vincula a um único e só valor, mas compreende, ao contrário, um complexo de valores. O bem-comum liga-se, em especial, diretamente ao valor do Justo, do equilíbrio e da harmonia social. A medida consubstanciada no projeto terá o sentido da justiça, se e quando estiver em ordem a realizar o valor do Justo, orientado que esteja em direção à liberdade e à igualdade de todos, especialmente no tocante à fruição dos bens da civilização."156
\end{abstract}

\subsection{Princípios e regras do processo legislativo}

Postos também como preceitos ou normas fundamentais de observância obrigatória na elaboração de norma legal, o Regimento Interno da Assembléia Legislativa do Amazonas (art. 249), acolhendo orientação já existente no Regimento do Senado Federal (art. 412), enumera os seguintes princípios do processo legislativo: igualdade das Deputadas e dos Deputados no exercício das atividades legislativas,

${ }^{156}$ Direito Parlamentar - Processo Legislativo. 2. ed., São Paulo: ALES/SGP, 2004, p. 91-92. 
observadas as próprias exceções regimentais; modificação da norma regimental somente por outra norma legislativa competente e desde que cumpridos rigorosamente os procedimentos exigidos no próprio Regimento; impossibilidade de prevalência sobre norma regimental expressa de qualquer acordo de Lideranças ou de qualquer decisão do Plenário que contrarie dispositivo regimental (no Senado, este preceito já mereceu alteração, mediante Resolução n.35/06, para deixar assente que acordos de Lideranças ou decisões do Plenário contrárias a normas regimentais podem sim sobre elas prevalecer, basta que as decisões sejam tomadas "por unanimidade, mediante voto nominal, resguardado o quorum mínimo de três quintos dos votos dos membros da Casa"); prevalência da norma especial sobre a geral; decisão dos casos omissos de acordo com a analogia e os princípios gerais do Direito; preservação dos direitos das minorias; definição normativa a ser observada pela Mesa, em questão de ordem decidida pela Presidência ou pelo Plenário; decisão colegiada, observadas as competências específicas estabelecidas no Regimento; impossibilidade de tomada de decisões sem a observância do quorum constitucional ou regimental estabelecido; pauta das matérias feita com antecedência tal que possibilite aos parlamentares conhecimento prévio; publicidade das decisões tomadas; possibilidade de ampla negociação política, desde que dentro dos limites "inerentes à ética parlamentar" e insertos no Regimento Interno.

Acordos de Lideranças não podem ignorar as normas regimentais postas e que disciplinam procedimentos legislativos. O Regimento Interno da Assembléia Legislativa de Minas Gerais adverte que não será recebido nem se tomará em conta acordo de Líderes que objetive "alterar essencialidades do processo legislativo" (art. $73, \S 5^{\circ}$ ). Remanesce, todavia, in casu, margem para interpretação do preciso alcance do termo "essencialidades". Sem contar que, em ordem afirmativa, ler-se-á que poderá ser recebido qualquer acordo de Líderes que vise a alterar o que não for essencial do processo legislativo. E, se se levar em conta, então, que as deliberações do Colégio de Líderes são tomadas por maioria absoluta (art. $73, \S 3^{\circ}$ ), pode não ser respeitado, por conseguinte, o efetivo direito da minoria de entender como essencial ao processo legislativo o que a maioria estiver entendendo como desnecessário, supérfluo.

A rigorosa observância do preceito (impossibilidade de prevalência sobre norma regimental expressa de qualquer acordo de Lideranças ou de qualquer decisão do Plenário que contrarie dispositivo regimental), no entanto, já acabou sucumbindo à 
prática parlamentar senatorial, que o flexibilizou ao aprovar Resolução dispondo sobre as condições para sua inobservância: basta que, ao menos, sessenta por cento da Casa Legislativa, em votação nominal, decida que a norma regimental não prevaleça em dada situação para que ela, então, fique suspensa. Há exigência de que nenhum voto dos deliberantes seja contrário. Esse o sentido do termo "unanimidade", utilizado pela Resolução 35/06, já que resguarda quorum mínimo de três quintos dos membros da Casa Legislativa, não a unanimidade [em relação ao quorum], que seria representada por cem por cento dos membros da Casa. Às vezes, as normas para a edição de outras normas, ou seja, os preceptivos regimentais para a feitura de leis, acabam por engessar os trabalhos legislativos, imobilizando-os. No Direito Parlamentar norte-americano há a figura da suspensão de regras, regimentalmente prevista. ${ }^{157}$ Bem se vê aí, a importância de se prever também fórmulas democráticas de solução de incertezas no procedimento legislativo. Busca-se assim evitar o tumulto, a confusão nos procedimentos de colegiados legislativos, desde que não estejam conflitantes com norma regimental e desde que não seja desrespeitada a minoria parlamentar. Vale dizer, as regras devem estar previstas; inclusive regras sobre a possibilidade e as condições de suspensão da eficácia dessas próprias regras.

\subsection{Precedentes parlamentares}

Quando o presidente dos trabalhos legislativos, a quem incumbe respeitar e fazer respeitar as normas regimentais, ao proferir uma decisão sobre um caso concreto no processo legislativo, registra que aquela decisão que está sendo tomada não deve ser invocada posteriormente, por não se constituir em um precedente, revela, contrario sensu, que há decisões que podem ser invocadas como precedentes em ordem a solucionar casos correlatos. Bem por isso, há Regimentos Internos que prevêem o necessário registro dessa fonte de direito parlamentar, os precedentes parlamentares, em livro próprio. ${ }^{158}$ Os registros servirão como fonte de consulta a embasar decisões

\footnotetext{
${ }^{157}$ House of Representatives - 108th Congress - 1st Session - Document 108-93: How our laws are made. Washington: U.S. Government printing office, 2003. p. 24. "Motion to suspend the rules - On Monday and Tuesday of each week and during the last six days of a session, the Speaker may entertain a motion to suspend the rules of the House and pass a public bill or resolution. Sometimes the motion is allowed on days other than Monday and Tuesday by unanimous consent or a rule from the Committee on Rules."

${ }^{158}$ Regimento Interno da Assembléia Legislativa de Minas Gerais, art. 169: “As decisões de caráter normativo sobre questões de ordem serão, juntamente com estas, registradas em livro próprio, com índice remissivo, e publicadas anualmente".
} 
futuras. Podem os precedentes parlamentares, se transformados em supedâneo de decisões em um mesmo sentido, servir como jurisprudência. Evidente que, se as próprias normas regimentais, fundamentadas na autonormatividade conferida expressamente pela Constituição Federal às Casas congressuais (art. 51, III; 52, XII; 57, § $3^{\text {a }}$, II) e às Assembléias Legislativas (art. 27, § $3^{\circ}$ ), devem observar as limitações impostas pelos preceitos constitucionais, a fortiori os precedentes parlamentares não estão autorizados a ultrapassar limites já traçados tanto por normas constitucionais como regimentais.

Da mesma forma, utiliza-se a expressão praxe parlamentar para indicar o que ocorre com certa regularidade nos trabalhos legislativos, e reveste-se, no direito parlamentar, de força para fundamentar decisão em situação parecida, mas controversa. Revela diretriz que pode ser seguida e que tem merecido, até então, indicação de regular observância de normas parlamentares consuetudinárias. Confirma esse entendimento a norma expressa do Regimento Interno da Assembléia Legislativa de Minas Gerais: “Art. 316 - Nos casos omissos, o Presidente da Assembléia aplicará o Regimento Interno da Câmara dos Deputados e, subsidiariamente, as praxes parlamentares". ${ }^{159}$

Tome-se, por exemplo, a votação de determinada proposição que não tenha alcançado, na sessão, quorum para deliberar, restando adiada a votação. Se, como praxe, em uma Casa Legislativa, não se submete novamente a votos, na mesma sessão, uma propositura, o presidente que o fizer infirmará sua autoridade na condução dos trabalhos legislativos.

Registre-se que da inobservância de expressa disposição regimental, qualquer parlamentar pode formular reclamação ao Presidente da sessão e, das respostas às reclamações, firmam-se orientações sobre as melhores práticas dos trabalhos legislativos. Já as dúvidas sobre a interpretação de Regimento Interno, na sua prática ou relacionada com a Constituição Federal ou com a Estadual, constituem-se em Questões de Ordem e, quando suscitadas por parlamentar(es), são necessariamente

\footnotetext{
Regimento Interno da Assembléia legislativa do Amazonas, art. 113: "As Questões de Ordem e as respectivas decisões de caráter normativo serão registradas em livro próprio, com índice remissivo, para apreciação da Mesa, com vistas à inserção no Regimento."

Regimento Interno da Assembléia Legislativa do Paraná, art. 106.

Regimento Interno da Assembléia Legislativa da Paraíba, art. 75, § 11.

159 Em www.almg.gov.br >legislação >legislação mineira<, há o registro de 16 decisões normativas da Presidência da Assembléia Legislativa de Minas Gerais.
} 
resolvidas pelo Presidente da Casa Legislativa, de pronto, ou, tempestivamente, dentro de determinado prazo. ${ }^{160}$ É facultado ao Presidente da Assembléia, no entanto, delegar ao Plenário a decisão final sobre Questão de Ordem. Observe-se que, como ato de interpretação de norma jurídica, a solução da Questão de Ordem não deixa de ser um ponto de vista da dúvida suscitada. Em regra, da decisão do Presidente da Assembléia sobre Questão de Ordem cabe recurso, sem efeito suspensivo, à Comissão de Constituição e Justiça.

${ }^{160}$ Em www.al.sp.gov.br >processo legislativo > questões de ordem<, há o registro, com inteiro teor, das indagações e respostas de 266 questões de ordem. 


\section{CAP. 5 PROCESSO LEGISLATIVO ESTADUAL}

A idéia de processo está associada à sua função ancilar de um direito material. Todavia, no processo legislativo residem as normas para elaboração das demais normas; no ordenamento jurídico, as normas acerca do processo legislativo são fundantes do próprio ordenamento jurídico, são normas sobre como deve proceder o legislador para a elaboração da própria legislação, diz respeito a normas primárias para a formação das leis. Como acentua Norberto Bobbio, são "normas para a produção de outras normas: é a presença e frequiência dessas normas que constituem a complexidade do ordenamento jurídico; e somente o estudo do ordenamento jurídico nos faz entender a natureza e a importância dessas normas". ${ }^{161}$

Ademais, salienta Jean Rivero, no processo de formação das leis é que se assentam, hoje, garantias de que elas não serão um atentado contra as liberdades dos cidadãos. Observa Rivero que "o fenômeno majoritário modificou profundamente a fisionomia do teatro político, aproximando o Legislativo do Executivo. Eis por que o valor liberal da lei já não repousa tanto, hoje, sobre o seu órgão de elaboração quanto sobre seu processo de elaboração. É ele, com efeito, que fornece aos cidadãos a garantia de que suas liberdades não serão arbitrariamente sacrificadas". ${ }^{162}$

O processo legislativo, afirma Raul Machado Horta, "não existe autonomamente, como valor em si, pois é técnica a serviço de concepções políticas, realizando fins do poder". ${ }^{163} \mathrm{E}$, como técnica a serviço de atuação parlamentar para consecução de fins políticos, o processo legislativo pode ser utilizado como instrumento de operacionalização em ordem a atingir os objetivos políticos desejados tanto pela maioria como pela minoria parlamentar, compostas por legítimos representantes do povo, e ambas dele farão uso para se atingir diferentes desideratos.

Evidente também que a importância das funções do Poder Legislativo, notadamente a de legislar, ficam relativizadas pela posição que o Legislativo ocupa no sistema político em que se insere, e, pois, relativa a importância dimensionada para o processo legislativo, notadamente o processo legislativo estadual, eis que inserido

\footnotetext{
${ }^{161}$ Teoria do ordenamento jurídico. 10. ed. Brasília: Ed. Universidade de Brasília, 1999. p. 47.

162 RIVERO, Jean; MOUTOUH, Hugues. Liberdades públicas. Trad. Maria Ermantina de Almeida Prado Galvão. São Paulo: Martins Fontes, 2006, p. 149.

${ }^{163}$ Direito constitucional. 3. ed. Belo Horizonte: Del Rey, 2002, p. 519.
} 
dentro dos limites da autonomia concebida pelo Constituinte Originário para os Estados-membros.

\subsection{Espécies legislativas estaduais}

Ao primeiro dos pressupostos do processo legislativo, existência de Parlamento, dedicou-se todo o capítulo 2 deste estudo, com ênfase para os Legislativos regionais; no capítulo seguinte, há análise sobre as competências dos Estados-membros na Federação brasileira. Fundamentação constitucional do processo legislativo, princípios e regras de procedimentos legislativos tudo isso foi a matéria do capítulo que antecede a este, sedimentando as bases para, então, se dar passo adiante na análise do segundo pressuposto do processo legislativo: a proposição legislativa, com realce para as proposições legislativas estaduais.

A análise que se segue tem como perspectiva aflorar questões, levantar dúvidas, fazer observações atinentes a peculiaridades que porventura surjam do exame das Constituições Estaduais e dos Regimentos Internos acerca das proposições legislativas adotadas pelos Estados Federados em ordem a constatar, ou não, norma vanguardeira que possa vislumbrar aperfeiçoamento do modelo federativo brasileiro.

As espécies normativas primárias são consubstanciadas após trâmite legislativo das respectivas espécies legislativas (proposta de emenda constitucional, projeto de lei complementar, projeto de lei ordinária, projeto de resolução-lei delegada, medida provisória-projeto de conversão de medida provisória, projeto de decreto legislativo, projeto de resolução).

Como assinala Alexandre de Moraes, as espécies normativas primárias "retiram seu fundamento de validade diretamente da Carta Magna". ${ }^{164}$

Em estudo pormenorizado sobre os limites jurídico-formais que os constituintes enfrentariam na elaboração das Constituições Estaduais, Anna Cândida da Cunha Ferraz, fundadamente salientava, em 1988, e antes do início dos trabalhos constituintes nos Estados, a autonomia dos Estados-membros na formulação do seu processo legislativo:

"Uma das limitações outrora impostas ao constituinte estadual era a observância estrita do processo legislativo federal (cf. Ferraz, 1988b, p.

${ }^{164}$ Direito constitucional. 21. ed. São Paulo: Atlas, 2007, p. 635. 
51). Conseqüência dessa imposição consistia no chamado 'fortalecimento do Poder Executivo', cujas acentuadas funções colegislativas representam um modelo acerbamente criticado de relacionamento entre Poderes Legislativo e Executivo no Brasil (cf. Ferreira Filho, 1986, p. 174 e seguintes).

A Constituição de 1988 suprimiu essa limitação. Podem assim os constituintes estaduais disciplinar livremente o processo de elaboração das leis estaduais ou copiar o modelo federal, se tal hes convier, adotando, por exemplo, as mesmas espécies normativas fixadas na $\mathrm{CF}$ (artigo 59) ou criando outras. ${ }^{.165}$ (sublinhou-se e negritou-se)

E, com o rigor científico que lhe é peculiar, alertava aqueles constituintes e, à época, registre-se, também legisladores ordinários:

"Ora, a liberdade de o constituinte estadual estabelecer o seu modelo de processo legislativo poderá ter reflexos no equilíbrio e relacionamento entre os poderes e, consequentemente, na mecânica da 'separação de poderes'.,"166

Mesmo não havendo mais a imposição de rigorosa observância do processo legislativo federal para o constituinte estadual e mesmo sabendo que o modelo de processo legislativo que adotassem refletiria na conformação da sistemática de separação de poderes, os constituintes estaduais (frise-se que, concomitantemente, também exerciam a função de legisladores), não ousaram criar novas espécies normativas nem alterar o equilíbrio de forças entre Executivo e Legislativo. Ao contrário, em alguns Estados, os constituintes-legisladores, em verdadeira capitis diminutio, acabaram por adotar também as medidas provisórias e as leis delegadas, exacerbando ainda mais o instrumental para o exercício de função legislativa pelos Governadores.

Carentes de criatividade, os constituintes estaduais copiaram as espécies legislativas previstas no processo legislativo federal, não criaram nenhuma nova. Por isso mesmo, à pesquisa nas vinte e seis Constituições Estaduais não se depara com nenhuma espécie nova, incluindo-se aí, além da emenda constitucional, a lei complementar, a lei ordinária, a lei delegada, a medida provisória, o decreto legislativo

\footnotetext{
${ }^{165}$ União, estado e município na nova Constituição: enfoque jurídico-formal, in A Nova Constituição Paulista; perspectivas. São Paulo: Fundação Prefeito Faria Lima - CEPAM, Fundação do Desenvolvimento Administrativo - FUNDAP, 1989. Textos apresentados no Seminário "Perspectivas para a Nova Constituição Paulista" 08-12 ago. 1988, p. 61.

${ }^{166}$ Idem, p. 62.
} 
e a resolução. Uma única ressalva poderia ser feita, e é ao constituinte catarinense que, ademais de inserir todas as espécies supra mencionadas, fez prever, no corpo do processo legislativo estadual, a "proposta de emenda à Constituição Federal" (art. 48, I, da Constituição de Santa Catarina), como forma de a Assembléia Legislativa catarinense efetivar titularidade para, juntamente com mais a metade das Assembléias Legislativas, proporem emenda à Constituição Federal. As demais Assembléias Legislativas operacionalizam essa atribuição de capacidade legislativa mediante decreto legislativo ou por intermédio de resolução.

Três Estados, ao menos, não acentuando o fortalecimento da função legislativa do Executivo, deixaram de adotar o regime das leis delegadas e o das medidas provisórias: São Paulo (art. 21), Rio Grande do Sul (art. 57) e Espírito Santo (art. 61).

Os demais adotaram um ou outro regime, ou os dois juntos.

Prevêem tão-somente leis delegadas: Alagoas (art. 84, IV), Amapá (art. 102, IV), Amazonas (art. 31, IV), Bahia (art. 72, VI), Ceará (art. 58, IV), Goiás (art. 18, IV), Mato Grosso (art. 37, IV), Mato Grosso do Sul (art. 65, IV), Minas Gerais (art. 63, IV), Pará (art. 102, IV), Paraná (art. 63, VI), Pernambuco (art. 16, IV), Rio de Janeiro (art. 110, IV), Rio Grande do Norte (art. 44, IV), Rondônia (art. 37, IV), Roraima (art. 38, III-A, pela EC n.13/02) e Sergipe (art. 54, V).

Seis Estados já dispõem de medidas provisórias no processo legislativo.

Medidas provisórias estão previstas pelas Constituições Estaduais do Maranhão (art. 40, IV) e do Piauí (art. 74, IV, acrescido pela EC de revisão n. 1/94), sendo que elas não adotaram a lei delegada. Acre (art. 52, IV e V), Paraíba (art. 61, IV e V), Santa Catarina (art. 48, V e VI) e Tocantins (art. 25, IV e V), além da lei delegada, adotam também a medida provisória como espécie legislativa.

\subsection{Proposições}

A matéria insere-se no tema processo legislativo, já tratado com ciência pela doutrina nacional. ${ }^{167} \mathrm{~A}$ análise que se segue, como já anotado, tem como perspectiva

\footnotetext{
${ }^{167}$ Superiormente por Manoel Gonçalves Ferreira Filho e José Afonso da Silva: FERREIRA FILHO, Manoel Gonçalves. Do processo legislativo. 6. ed. São Paulo: Saraiva, 2007. SILVA, José Afonso da. Processo constitucional de formação das leis. 2. ed. São Paulo: Malheiros, 2006.
} 
apenas aflorar questões, levantar dúvidas, fazer observações atinentes a peculiaridades que porventura surjam do estudo das Constituições Estaduais e dos Regimentos Internos sobre as proposições legislativas adotadas pelos Estados Federados em ordem a constatar, ou não, norma vanguardeira que possa vislumbrar aperfeiçoamento do modelo federativo brasileiro.

\subsubsection{Proposta de Emenda constitucional}

Diferentemente da Federação argentina com Legislativos provinciais ${ }^{168}$ uni e bicamerais $^{169}$, nos Estados da Federação brasileira, as modificações das suas Constituições são efetivadas sempre por Legislativos unicamerais, compostos por Deputados legisladores, aos quais se atribui competência constituinte decorrente.

A jurisprudência do Supremo Tribunal Federal consolidou-se no sentido de se exigir dos Estados-membros observância aos postulados que regem o processo de emenda à Constituição Federal: procedimento que efetive dualidade de turnos seqüenciais de discussão e votação, e aprovação por 3/5 dos membros das Assembléias Legislativas. Tem-se que essas limitações formais são impostas de modo subordinante aos constituintes decorrentes. ${ }^{170}$ Subordina-se, ainda, o Poder Constituinte Decorrente às demais condições de emendabilidade a que o Poder Constituinte Derivado se submete, por expressa vontade do Poder Constituinte Originário (art. 60, $\S 1^{\circ}, 4^{\circ}$ e $5^{\circ}$ ).

Cf. também, MORAES, Alexandre. Direito constitucional. 21. ed. São Paulo: Atlas, 2007; SAMPAIO, Nelson de Souza. O processo legislativo. 2. ed. Belo Horizonte: Del Rey 1996; SPROESSER, Andyara Klopstock. Direito Parlamentar - Processo Legislativo. 2. ed. São Paulo: Alesp/SGP, 2004; ATALIBA, Geraldo. Lei complementar na Constituição. São Paulo: Revista dos Tribunais, 1971; CLÈVE, Cleverson Merlin. Atividade legislativa do Poder Executivo no Estado contemporâneo e na Constituição de 1988. São Paulo: Ed. Revista dos Tribunais, 2000; PAULO, Vicente e ALEXANDRINO, Vicente. Processo legislativo. 2. ed. Niterói,RJ: Impetus, 2005; AZEVEDO, Márcia Maria Corrêa de. Prática do processo legislativo. São Paulo: Atlas, 2001; COELHO, Fábio Alexandre. Processo legislativo. São Paulo: Ed. Juarez de Oliveira, 2007; CASSEB, Paulo Adib. Processo legislativo. São Paulo: Ed. Revista dos Tribunais, 2008; DUARTE NETO, José. A iniciativa popular na Constituição Federal. São Paulo: Ed. Revista dos Tribunais, 2005; HORTA, Raul Machado. Direito constitucional. 3. ed. Belo Horizonte: Del Rey, 2002; JAMPAULO JÚNIOR, João. O processo legislativo - sanção e vício de iniciativa. São Paulo: Malheiros, 2008. CARVALHO, Kildare Gonçalves. Direito constitucional. 11. ed. Belo Horizonte: Del Rey, 2006. BENETON, Marco Antonio Hatem. O processo legislativo financeiro. (Tese Doutorado) São Paulo: Fadusp, 2007; RIZEK JUNIOR, Rubens Naman. Os Parlamentos frente às inovações do processo legislativo. (Dissertação Mestrado) São Paulo: Fadusp, 2001.

${ }^{168}$ ALBERDI, Juan Bautista. Derecho público provincial argentino. Buenos Aires: Tall. gráf. L. J. Rosso y cia., 1917.

169 Legislativos provinciais argentinos bicamerais: Santa Fé, Mendoza, Entre Rios, San Luis (1987), Catamarca (1988), Corrientes (1993), Buenos Aires (1998) e Salta (1998).

Legislativos provinciais argentino unicamerais: Missiones, Neuquén, San Juan (1986), Jujuy (1986), Rio Negro (1988), Formosa (1991), Tierra del Fuego (1991), Santa Cruz (1994), Chubut (1994), Chaco (1994), La Pampa (1994), Santiago Del Estero (1997), Córdoba (2001), La Rioja (2002), Tucumán (2006) e Buenos Aires (DF).

${ }^{170}$ ADI n. 486-DF. 
Já quanto à titularidade de iniciativa para alterar as respectivas Constituições, os constituintes de quatorze Estados afastaram-se do parâmetro federal e previram a possibilidade de a iniciativa popular consubstanciar proposta de emenda à Constituição Estadual: Acre (art. 53, III, e $§ 5^{\circ}$ ); Alagoas (art. 85, IV); Amapá (art. 103, IV); Amazonas (art. 32, IV); Bahia (art. 74, IV); Espírito Santo (arts. 62, III, e 69); Goiás (art. 19, IV); Pará (arts. $8^{\circ}$ e 103, V); Paraíba (art. 62, IV); Pernambuco (art. 17, III); Rio Grande do Sul (arts. 58, IV, e 68); Roraima (art. 39, IV); Santa Catarina (art. 49, IV); São Paulo (art. 22, IV); e Sergipe (art. 55, IV). Sobre essa matéria ainda não há ${ }^{171}$ qualquer manifestação do Supremo Tribunal Federal.

Ao "Tribunal de Justiça, após aprovação pela maioria dos desembargadores", a Constituição do Estado do Pará (art. 103, III) concedeu também competência para deflagrar o processo legislativo de proposta de emenda à Constituição Estadual. Trata-se de atribuição somente concedida pelo constituinte estadual paraense e não guarda nenhuma simetria com os titulares deste mesmo direito estatuído na Constituição Federal.

Da mesma forma, não observando os paradigmas previstos na Constituição Federal, mas com viés restritivo impróprio, exige-se subscrição de, no mínimo, 2/3 (dois terços) dos membros da Assembléia Legislativa de Roraima para se outorgar titularidade em ordem a apresentação de proposta de emenda àquela Constituição Estadual (art. 39, I). E, com semelhante caráter restritivo, observe-se que à Constituição do Estado do Rio Grande do Norte tão-somente dois titulares possuem capacidade para propor emenda constitucional: o Governador e 1/3 (um terço), no mínimo, dos membros da Assembléia Legislativa (art. 45, I e II).

\subsubsection{Projeto de Lei complementar}

Ao contrário da Constituição Federal que, pontualmente, assinala que determinada matéria deva ser normatizada mediante lei complementar, há Constituições Estaduais que adotam como critério indicar em um mesmo artigo o rol das matérias que carecem de aprovação por maioria absoluta dos membros da Assembléia Legislativa. Assim procederam os constituintes estaduais do Acre (art. 56, parágrafo único, incisos I a XIII), do Espírito Santo (art. 68, parágrafo único, incisos I a XI),de Mato Grosso (art. 45, parágrafo único, incisos I a XVI), de Minas Gerais (art. 65, § 2º incisos I a

\footnotetext{
${ }^{171}$ Consulta à Seção de Pesquisa de Jurisprudência do STF, com resposta em 10-12-08.
} 
IV), do Pará (art. 113, parágrafo único, incisos I a III), do Piauí (art. 77, parágrafo único, incisos I a X), de Pernambuco (art. 18, parágrafo único, incisos I a XVI), do Rio de Janeiro (art. 118, parágrafo único, incisos I a X), do Rio Grande do Norte (art. 48, incisos I a V), de Roraima (art. 40, parágrafo único, incisos I a XVIII), de Santa Catarina (art. 57, parágrafo único, incisos I a VIII), de São Paulo (art. 23, parágrafo único, itens 1 a 18), e de Sergipe (art. 60, §1º, incisos I a V). O rol não é exaustivo, haja vista que se utiliza a expressão "entre outras matérias"(Minas Gerais, e.g.), e as próprias exceções no corpo das Constituições, notadamente a que prescreve que, por lei complementar, poderão ser acrescidas outras atribuições ao cargo de ViceGovernador do Estado; bem por isso, partilham, também, do sistema adotado pelo constituinte federal.

À guisa de informação, no âmbito estadual foram consideradas matéria de lei complementar: 1) a lei de organização judiciária; 2) a lei orgânica do Ministério Público; 3) a lei orgânica da Procuradoria Geral do Estado; 4) a lei orgânica da Defensoria Geral; 5) a lei orgânica da Polícia Civil; a lei orgânica da Polícia Militar; 6) a lei orgânica do Tribunal de Contas; 7) a lei orgânica das entidades descentralizadas; 8) a lei orgânica do Fisco estadual; 9) os estatutos dos servidores civis e militares; 10) o código de Educação; 11) o código de Saúde; 12) o código de Saneamento Básico; 13) o código de Proteção ao Meio Ambiente; 14) o código estadual de Proteção Contra Incêndios e Emergências; 15) a lei sobre normas técnicas de elaboração legislativa; 16) a lei que impuser requisitos para classificação de Municípios como estância de qualquer natureza; 17) as leis que instituírem regiões metropolitanas, aglomerações urbanas e microrregiões.

Importa indagar se os constituintes estaduais devem também observar, simetricamente, a mesma sistemática para as matérias que já mereceram do constituinte federal a indicação de normatização mediante lei complementar. O Supremo Tribunal Federal, com fundamento no "tal princípio de simetria necessária" — assim referido pelo Min. Sepúlveda Pertence, não "simetrista", em voto proferido na ADI-MC n. 2.314-4/RJ (p. 206) —, tem decidido que a observância é obrigatória. ${ }^{172}$ No entanto, no

\footnotetext{
${ }^{172}$ Nesse sentido: ADI n. 805/RS, rel.Min. Celso de Mello, RTJ 152/71 e RTJ 168/391; ADI n. 822/RS, rel. Min. Sepúlveda Pertence, RTJ 150/482, RDA 191/194 e RTJ 163/882; ADI n. 872/RS, rel. Min. Sepúlveda Pertence, RTJ 151/425 e RDA 197/152; ADI n. 1.070/MS, rel. Min. Celso de Mello, RTJ 168/87; ADI n. 1.087/RJ, rel. Min. Moreira Alves, Lex-JSTF 199/43; ADI n. 1.196/RO, rel. Min. Octávio Gallotti, Lex-JSTF 199/79; ADI n. 1.254/RJ, rel. Min. Sepúlveda Pertence, RTJ 170/792 e RTJ 170/801 e Lex-JSTF 260/67; ADI n. 1.434/SP, rel. Min. Celso de Mello, RTJ 164/506
} 
julgamento, ainda não concluído, da ADI n. 2.872/PI, em 29 de outubro de 2008, relator Min. Eros Grau, o Min. Menezes Direito, abrindo divergência, salientou que o princípio da simetria deve comportar modulação, no que foi acompanhado pela Min. Cármen Lúcia. Informa-se que “considerou que a legislação ordinária no âmbito federal, que dispensa o quorum mais rigoroso da lei complementar, não impede que, na competência dos Estados-membros, seja possível exigir lei complementar. Frisou que a força da Federação brasileira deve estar exatamente na compreensão de que os Estados-membros podem fazer opções constitucionais locais com os padrões normativos disponíveis na Constituição Federal sem que isso malfira, em nenhum aspecto, qualquer princípio sensível ou qualquer limitação expressa ou implícita, e concluiu não vislumbrar razão alguma para a aplicação alargada do aludido postulado". ${ }^{173}$ (negritou-se)

Decorrente também de sistemática de enquadramento que não observou correspondência da matéria ao se exigir, no plano estadual, lei complementar, quando no federal prevê-se legislação ordinária, o Tribunal de Justiça do Estado de São Paulo, em ação direta de inconstitucionalidade de lei n. 76.072-0/9, acolheu argumentos para declarar inconstitucional a lei ordinária n. 8.992/94, por invadir campo privativo da matéria que, por escolha do constituinte estadual, deveria ser disciplinada por lei complementar (Lei Orgânica da Polícia Militar, e Estatutos dos Servidores Civis e dos Militares - art. 23, parágrafo único, itens 6 e 10 da Constituição Estadual). ${ }^{174}$

\subsubsection{Projeto de Lei ordinária}

Obviamente que, desde 1934, sendo unicameral a estrutura dos Legislativos estaduais, todas as disposições da Constituição Federal sobre processo de formação da lei que provierem do caráter bicameral do Congresso Nacional há que se por de lado.

O projeto de lei ordinária estadual visa à edição de lei, ato normativo primário escrito, instaurando direito novo, mediante aprovação da Assembléia Legislativa com a participação do Governador, sobre matéria autorizada pela

e $R T J$ 172/789; ADI n. 1.594/RN, rel. Min. Nelson Jobim, RTJ 162/507; ADI n. 1.568/ES, rel. Min. Carlos Velloso, RTJ 163/957; ADI n. 276/AL, rel. Min. Celso de Mello, RTJ 132/1057; ADI n. 766/RS, rel. Min. Celso de Mello, RTJ 157/460; ADI n. 1.060/RS, rel. Min. Carlos Velloso, RDA 199/173; ADI n. 1.690/AP, rel. Min. Nelson Jobim, RTJ 170/75; ADI n. 774/RS, rel. Min. Celso de Mello, RTJ 171/391 e RTJ 171/397; ADI n. 575/PI, rel. Min. Sepúlveda Pertence, RTJ 169/834; ADIMC n. 1.391/SP, rel. Min. Celso de Mello, Lex-JSTF 288/32.

${ }^{173} \mathrm{STF}$ - Informativo n. 526.

${ }^{174}$ TJSP - Órgão Especial. Relator desembargador Vallim Bellocchi, v.u., j. 7-11-2001. 
Constituição Federal, e na forma prevista pelas respectivas Constituições Estaduais e pelos respectivos Regimentos Internos das Assembléias Legislativas.

Despiciendo anotar o valor da lei no Estado de Direito, visto que "este se caracteriza fundamentalmente pela sujeição de tudo e de todos à lei, conforme o princípio de que ninguém está obrigado a fazer ou a deixar de fazer alguma coisa senão em virtude de lei". ${ }^{175}$

\subsubsection{Lei delegada}

As leis delegadas são elaboradas pelo Governador do Estado, por solicitação sua ao Poder Legislativo. Se a Assembléia Legislativa entender de conceder a delegação, consubstanciá-la-á em Resolução da Assembléia ${ }^{176}$, especificando, neste diploma, o conteúdo da delegação e os termos do seu exercício. Assim autorizado, o Governador, então, elabora e promulga o texto da lei, impondo-se-lhe o respeito aos parâmetros do conteúdo já especificado e, à evidência, dos termos inicial e final para o seu exercício.

Há limites materiais à delegação postos pelo poder constituinte. $\mathrm{O}$ de Minas Gerais estabeleceu que não podem constituir objeto de delegação os atos de competência privativa da Assembléia Legislativa; a matéria reservada a lei complementar $^{177}$; a legislação sobre organização do Poder Judiciário, do Ministério Público e do Tribunal de Contas, a carreira e as garantias de seus membros, bem assim a carreira e a remuneração dos servidores de suas Secretarias; os planos plurianuais, as diretrizes orçamentárias e os orçamentos (art. 72, § $1^{\text {o }}$, I e II).

Anote-se, também, que, em observância ao princípio da irrenunciabilidade das funções legislativas, mesmo durante o tempo em que deva ser exercida a delegação pelo Governador, a Assembléia Legislativa remanesce com a atribuição de legislar sobre a matéria delegada. Assim como o Governador, mesmo já habilitado pelo

\footnotetext{
${ }^{175}$ FERREIRA FILHO, Manoel Gonçalves. Do processo legislativo. $6^{\mathrm{a}}$ ed. São Paulo: Saraiva, 2007, p. 205.

${ }^{176}$ A Constituição do Estado do Pará prevê que "a delegação ao Governador terá a forma de decreto legislativo" (art. 112, § $2^{\circ}$ ).

177 “Art. 65 (...) $\S 2^{\circ}$ - Consideram-se leis complementares, entre outras matérias previstas nesta Constituição:

I - o Código de Finanças Públicas e o Código Tributário;

II - a Lei de Organização e Divisão Judiciárias;

III - o Estatuto dos Servidores Públicos Civis e o Estatuto dos Servidores Públicos Militares; e

IV - as leis orgânicas do Ministério Público, do Tribunal de Contas, da Advocacia do Estado, da Defensoria Pública, da Polícia Civil e da Polícia Militar.”
} 
Legislativo para promulgar lei delegada, pode, em avaliação de conveniência e oportunidade, não vir a editá-la. ${ }^{178}$

Decorrente do conteúdo da iniciativa solicitadora do Governador e da deliberação do Legislativo, é possível que uma só Resolução da Assembléia Legislativa autorize a promulgação de uma ou mais leis delegadas.

Se o Governador, ao promulgar lei delegada, exorbitar dos limites da delegação legislativa previstos na Resolução, impõe-se à Assembléia Legislativa a sustação, mediante decreto legislativo, dos dispositivos exorbitantes.

Embora não haja na Constituição de 1988, como havia na ordem constitucional imediatamente anterior, referências à delegação interna corporis, as Constituições Estaduais do Acre (art. 57, caput) e do Ceará (art.64, caput) prevêem-na.

Sob a vigência da atual ordem constitucional, os Estados do Espírito Santo (art. 61), Rio Grande do Sul (art. 57) e de São Paulo (art. 21) não adotaram o regime de leis delegadas, os demais o tem previsto .

No ordenamento jurídico brasileiro, até agora, constam somente 13 leis delegadas. Sob a égide da Constituição de 1988 foram promulgadas 2 leis delegadas: a Lei Delegada n. 12, de 7 de agosto de 1992, e a Lei Delegada n. 13, de 27 de agosto de 1992, ambas decorrentes de autorizações constantes da Resolução n. 1, de 1992, do Congresso Nacional.

Em Minas Gerais, a lei delegada tem sido deveras prestigiada. De fato, consultando-se a legislação mineira, ${ }^{179}$ constata-se a existência de 178 leis delegadas; dessas, 48 foram editadas entre 1985 e 2002, as demais (130) foram promulgadas entre 2003 e 2007. A título de mera exemplificação do procedimento legislativo de lei delegada, traz-se à observação: 1) a mensagem do Governador (de Minas Gerais) contendo a iniciativa solicitadora, 2) o projeto de Resolução consubstanciando o conteúdo e termos da delegação, 3) a Resolução do Legislativo, e 4) a Lei Delegada promulgada pelo Governador. Impende notar que uma única Resolução, a de n.5.294 (abaixo transcrita), de 15 de dezembro de 2006, da Assembléia Legislativa de Minas Gerais, que delegou ao Governador do Estado "atribuição para elaborar leis destinadas a alterar a estrutura da administração direta e indireta do Poder Executivo", acabou por fundamentar a

178 CALIMAN, Auro Augusto. Leis Delegadas e Medidas Provisórias: notas sobre a atividade legislativa do Executivo no Brasil. In: Revista Jurídica 9 de Julho. São Paulo: Alesp, n. 2, 2003 , p. 191-211.

179 www.almg.gov.br (consulta realizada em 16-1-09) 
promulgação de 66 leis delegadas (Lei Delegada n. 112 até Lei Delegada n. 178), como se há de constatar em consulta à legislação mineira, supra mencionada.

\title{
5.2.4.1 Iniciativa solicitadora do Governador:
}

\section{"MENSAGEM N 692/2006}

Belo Horizonte, 21 de novembro de 2006.

Excelentíssimo Senhor Presidente da Assembléia Legislativa,

Tenho a honra de dirigir-me a Vossa Excelência para solicitar a essa egrégia Assembléia Legislativa autorização para elaborar leis delegadas nos termos do art. 72 da Constituição do Estado, de forma a viabilizar a implementação do Programa de Governo "Pacto por Minas: estratégias para a transformação social", segundo o qual fui eleito.

Inseridos nesta perspectiva estão os programas que terão a preocupação de dar mais qualidade aos gastos públicos, meta definida como "Choque de Gestão de segunda geração". Tal mecanismo permitirá a reestruturação organizacional dos órgãos e entidades do Poder Executivo, alinhada ao propósito de seguir gastando menos com o governo e mais com a população.

Urge salientar que a delegação feita no início do primeiro mandato permitiu que fosse levado a cabo, entre outros projetos, o do Choque de Gestão. Constatou-se que este projeto não foi meramente um mote de campanha ou uma expressão vazia. De fato, o amplo, inovador e corajoso processo de recuperação institucional do Estado foi capaz de devolver ao Poder Executivo estadual condições de governança suficientes para a apresentação de excelentes resultados, em todos os setores da administração pública.

Agora, surge o momento de se consolidar o projeto e de se adensarem seus resultados em benefício da sociedade mineira. O pilar fundamental da segunda geração do Choque de Gestão será o aprofundamento de uma perseguição insistente de um estado de resultados, com grande preocupação com a qualidade do gasto, amparado no binômio: qualidade fiscal e gestão eficiente. Mais e mais, os efeitos do Choque de Gestão deverão ser percebidos, permitindo a melhoria efetiva e mensurável da vida dos mineiros.

$\mathrm{E}$, neste relevante momento, conto mais uma vez com a colaboração dessa egrégia Casa Legislativa para alcançar a meta mobilizadora de se fazer de Minas Gerais o melhor lugar para se viver.

Para tanto, solicito que a delegação se dê para: criar, incorporar, transferir, extinguir e alterar órgãos públicos, inclusive autônomos, ou unidades da administração direta, bem como modificar a estrutura orgânica das entidades da administração indireta, definindo suas atribuições, objetivos e denominações; criar, transformar e extinguir cargos de provimento em comissão e funções de confiança dos órgãos e entidades do Poder Executivo, bem como gratificações e parcelas remuneratórias a estes inerentes, alterar-lhes as denominações, atribuições, requisitos para ocupação, forma de recrutamento, sistemática de remuneração, jornada de trabalho e distribuição; proceder à realocação de atividades e programas no âmbito do Poder Executivo e ao remanejamento de dotações orçamentárias em decorrência da aplicação no disposto nos itens anteriores; alterar as vinculações das entidades da administração indireta; e vigorar até 31 de janeiro de 2007.

Demonstrada a importância desta matéria para o aumento do dinamismo e da efetividade de ações da administração pública do Estado de Minas Gerais, submeto à elevada apreciação de seus nobres pares a apreciação da proposta.

Atenciosamente,

Aécio Neves, Governador do Estado."

\subsubsection{Projeto de Resolução consubstanciando o conteúdo da delegação solicitada:}

\author{
“PROJETO DE RESOLUÇÃO n. 3.768/2006
}


Delega ao Governador do Estado atribuição para elaborar leis destinadas a alterar a estrutura da administração direta e indireta do Poder Executivo, nos termos que

A Assembléia Legislativa do Estado de Minas Gerais aprova:

menciona.

Art. $1^{\circ}$ - Fica delegada ao Governador do Estado, nos termos do art. 72 da Constituição do Estado, atribuição para elaborar leis destinadas à implementação do Programa de Governo Pacto por Minas: Estratégias para a Transformação Social, com poderes limitados a:

I - criar, incorporar, transferir, extinguir e alterar órgãos públicos, inclusive autônomos, ou unidades da administração direta, bem como modificar a estrutura orgânica das entidades da administração indireta, definindo suas atribuições, objetivos e denominações;

II - criar, transformar e extinguir cargos em comissão e funções de confiança dos órgãos e entidades do Poder Executivo e alterar-lhes as denominações, as atribuições, os requisitos para ocupação, a forma de recrutamento, a sistemática de remuneração, a jornada de trabalho e a distribuição na estrutura administrativa;

III - dispor sobre as parcelas remuneratórias, incluídas as gratificações, dos cargos a que se refere o inciso II;

IV - proceder à realocação de atividades e programas no âmbito do Poder Executivo e ao remanejamento de dotações orçamentárias em decorrência da aplicação do disposto neste artigo;

V - alterar as vinculações das entidades da administração indireta.

Art. $2^{\circ}$ - A delegação de atribuição constante nesta resolução estende-se até a data de 31 de janeiro de 2007.

Art. $3^{\circ}$ - Esta resolução entra em vigor na data de sua publicação.

Sala das Reuniões, 29 de novembro de 2006.

Comissão de Constituição e Justiça”

\subsubsection{Resolução da Assembléia}

“RESOLUÇÃO n. 5.294, de 15 de dezembro de 2006

Delega ao Governador do Estado atribuição para elaborar leis destinadas a alterar a estrutura da administração direta e indireta do Poder Executivo, nos termos que menciona.

Faço saber que a Assembléia Legislativa do Estado de Minas Gerais aprovou e eu promulgo a seguinte resolução:

Art. $1^{\circ}$ - Fica delegada ao Governador do Estado, nos termos do art. 72 da Constituição do Estado, atribuição para elaborar leis destinadas à implementação do programa de governo Pacto por Minas: Estratégias para a Transformação Social, com poderes limitados a:

I - criar, incorporar, transferir, extinguir e alterar órgãos públicos, inclusive autônomos, ou unidades da administração direta, bem como modificar a estrutura orgânica das entidades da administração indireta, definindo suas atribuições, objetivos e denominações;

II - criar, transformar e extinguir cargos em comissão e funções de confiança de órgãos e entidades do Poder Executivo e alterar-lhes as denominações, as atribuições, os requisitos para ocupação, a forma de recrutamento, a sistemática de remuneração, a jornada de trabalho e a distribuição na estrutura administrativa;

III - dispor sobre as parcelas remuneratórias, incluídas as gratificações, dos cargos a que se refere o inciso II; 
IV - proceder à realocação de atividades e programas no âmbito do Poder Executivo;

$\mathrm{V}$ - alterar as vinculações das entidades da administração indireta.

Art. $2^{\circ}$ - A delegação de atribuição constante nesta resolução estende-se até a data de 31 de janeiro de 2007 e não abrange as empresas públicas e as sociedades de economia mista integrantes da Administração indireta estadual.

Art. $3^{\circ}$ - Esta resolução entra em vigor na data de sua publicação.

Palácio da Inconfidência, em Belo Horizonte, aos 15 de dezembro de 2006; $218^{\circ}$ da Inconfidência Mineira e $185^{\circ}$ da Independência do Brasil.

Mauri Torres, Presidente da ALMG."

\subsubsection{Lei Delegada}

“LEI DELEGADA n. 112, de 25 de janeiro de 2007

Dispõe sobre a organização e a estrutura da Administração Pública do Poder Executivo do Estado e dá outras providências

O GOVERNADOR DO ESTADO DE MINAS GERAIS, no uso de atribuição que lhe confere o inciso IX do art. 90, da Constituição do Estado, e tendo em vista o disposto na Resolução n. 5.294, de 15 de dezembro de 2006, da Assembléia Legislativa do Estado de Minas Gerais, decreta a seguinte Lei Delegada:

Art. $1^{\circ}-(\ldots)$

Art. 35 - Esta Lei Delegada entra em vigor ...”

E seguem-se outras 65 leis delegadas com fundamento na mesma Resolução n. $5.294 / 2006 .^{180}$

\subsubsection{Medida provisória}

A adoção de medidas provisórias pelos Estados-membros foi tema controverso entre juristas. Manoel Gonçalves Ferreira Filho, na terceira edição de obra clássica, Do Processo Legislativo, em 1995, afirmava: "De modo algum, porém, a admissão de medida provisória com força de lei, que é uma exceção (e aberrante) ao próprio sistema da Constituição brasileira". ${ }^{181}$ José Afonso da Silva, em 1994, discutindo o assunto, indagava: "podem as Constituições estaduais instituí-las? Na edição anterior, respondemos que nada justificava sua existência no âmbito estadual, mas não víamos proibição em que o fizesse. Até onde sabemos, os Estados (e também os Municípios) evitaram adotá-las. E hoje, re melius propensa, achamos ponderável o argumento de que, sendo exceção ao princípio da divisão de poderes, só valem nos limites estritos em que foram elas previstas na Constituição Federal, ou seja, apenas no

\footnotetext{
${ }^{180}$ Cf. $\underline{\text { www.almg.gov.br }}$ (consulta à legislação mineira)
}

${ }^{181}$ Ob. cit., p. 244. 
âmbito federal, não se legitimando seu acolhimento nos Estados nem nos Municípios". 182

Voz distoante, à época, a de Roque Carraza, salientando que "nada impede, porém, que, exercitando seus poderes constituintes decorrentes, os Estados, os Municípios e o Distrito Federal prevejam a edição de medidas provisórias, respectivamente, estaduais, municipais e distritais. A elas, mutatis mutandis, devem ser aplicados os princípios e limitações que cercam as medidas provisórias federais". ${ }^{183}$ Nesse sentido também, Regina Macedo Néri Ferrari: “A atual CF de 1988 não proíbe que os Estados e Municípios adotem as medidas provisórias, o que possibilita sua previsão em Constituições Estaduais e Leis Orgânicas Municipais". ${ }^{184}$

O Supremo Tribunal Federal, na ADI 425-5/TO, rel. Min. Maurício Corrêa, espancando dúvidas doutrinárias decidiu, por maioria, em 04-09-2002, que os Estadosmembros podem adotar o regime das medidas provisórias, pois não há no vigente sistema constitucional pátrio qualquer limitação imposta às unidades federadas para a edição de medidas provisórias. Os Deputados Estaduais, no exercício do poder constituinte decorrente, detêm legitimidade para adotar, ou não, essa espécie legislativa no processo legislativo estadual.

A Emenda Constitucional n. 5, de 15 de agosto de 1995, ao dar nova redação ao $\S 2^{\circ}$ do art. 25, vedou aos Estados-membros a edição de medida provisória para regulamentação da exploração dos serviços locais de gás canalizado, exigindo que a regulamentação se fizesse por lei ordinária. Na exegese desse dispositivo, em decisão de 16-8-2006 do Supremo Tribunal Federal, a relatora da ADI n. 2.391/SC, Ministra relatora Ellen Gracie, forte na argumentação contrario sensu, salientava:

“3. (...) se a Constituição Federal não autorizou explicitamente os Estados-membros a adotarem medidas provisórias, ofereceu forte e significativa indicação quanto a essa possibilidade, ao estabelecer, no capítulo referente à organização e à regência dos Estados, a competência desses entes da Federação para "explorar diretamente, ou mediante concessão, os serviços locais de gás canalizado, na forma da lei, vedada a edição de medida provisória para a sua regulamentação" $\left(\mathrm{CF}\right.$, art. $\left.25, \S 2^{\circ}\right)$. Concluir de forma diversa nos levaria a indagar, inevitavelmente, se teria sentido endereçar tal restrição ao Presidente da República em dispositivo que trata apenas de atividade exclusiva de

\footnotetext{
${ }^{182}$ Curso de Direito Constitucional Positivo. São Paulo: Malheiros, 1994, p. 533.

${ }^{183}$ Curso de direito constitucional tributário. 2. ed. São Paulo: RT, 1991, p. 157, nota 28.

${ }^{184}$ Medidas Provisórias - Estados e Municípios. In Cadernos de Direito Constitucional e Ciências Políticas. São Paulo: Ed. RT, n. 19, abr./jun., 1997, p. 93.
} 
outros partícipes da Federação que não a União ou, ainda, por que motivo a Constituição Federal imporia uma proibição específica quanto à utilização, pelos Estados-membros, de instrumento legislativo que lhes fosse vedado instituir. A inexistência, ao que me parece, de respostas razoáveis a esses questionamentos, conduz à conclusão obtida pela Corte na apreciação da ADI 425, no sentido da constitucionalidade da adoção de medidas provisórias pelos Estados, com a condição inafastável de que esse instrumento esteja expressamente previsto na Constituição Estadual e nos mesmos moldes impostos pela Constituição Federal, tendo em vista a necessidade da observância simétrica do processo legislativo federal."

Como registrado supra, seis Estados ${ }^{186}$ já dispõem de medidas provisórias: Acre (art. 52, V), Maranhão (art. 40, IV), Piauí (art. 74, IV), Paraíba (art. 61, V), Santa Catarina (art. 48, VI) ${ }^{187}$ e Tocantins (art. 25, V). Com efeito, os Estadosmembros dispõem, em sua autonomia, da competência para adotar, ou não, o regime de medidas provisórias. Como nos próprios constituintes-legisladores decorrentes recaiu a decisão de adotá-lo e, agora, dar-se-ia mediante aprovação em emenda constitucional pelos próprios Deputados Estaduais, a eles também deverá ser debitado o esvaziamento de suas próprias atribuições legislativas em prol do Executivo, em acintosa capitis diminutio da função legislativa da respectiva Assembléia Legislativa.

\subsubsection{Projeto de Decreto Legislativo}

Trata-se de proposição que tem por escopo regular matérias de exclusiva competência do Legislativo Estadual, sem a sanção do Governador. Andyara Klopstock Sproesser assinala que a nota distintiva do decreto legislativo é "a de se destinar, por natureza, especificamente, a produzir efeitos externos". ${ }^{188}$

\footnotetext{
${ }^{185}$ STF - Pleno - ADI n. 2.391/SC - Rel. Min. Ellen Gracie, decisão: 16-8-2006 - Informativo STF n. 437.

${ }^{186}$ Número de Medidas Provisórias editadas até janeiro de 2009: Santa Catarina - 148 ; Paraíba 119; Piauí - nenhuma; Tocantins - 381; Maranhão - 35 (2004: 5; 2005: 1; 2006: 7; 2007: 15; 2008: 7); Acre - ? (informação de difícil acesso, mesmo após dezenas de telefonemas ao Poder Legislativo e ao Poder Executivo desse Estado).

${ }^{187} \mathrm{Na}$ Constituição do Estado de Santa Catarina, art. 51, objeto da ADI n. 2.391/SC:

“Art. 51. Em caso de relevância e urgência, o Governador do Estado poderá adotar medidas provisórias, com força de lei, devendo submetê-las de imediato a Assembléia Legislativa, que, estando em recesso, será convocada extraordinariamente no prazo de cinco dias.

$\S 1^{\circ}$ As medidas provisórias perderão eficácia, desde a edição, se não forem convertidas em lei no prazo de trinta dias a partir de sua publicação, devendo a Assembléia Legislativa disciplinar as relações jurídicas delas decorrentes.

$\S 2^{\circ}$ É vedada a edição de medida provisória sobre matéria que não possa ser objeto de lei delegada.

$\S 3^{\circ}$ É vedada a reedição, na mesma sessão legislativa, de medida provisória não deliberada ou rejeitada pela Assembléia Legislativa."

${ }^{188}$ Direito Parlamentar - Processo Legislativo. 2. ed. São Paulo: ALESP/SGP, 2004, p. 170.
} 
O Regimento Interno da Assembléia Legislativa da Bahia dispõe que, dentre outras, serão objeto de decreto legislativo as deliberações da Casa que (a) julguem as contas do Governador; ( $b$ )aprovem ou autorizem acordos com a União, outros Estados ou Municípios; (c)declarem a procedência de acusação, impedimento e perda de cargo do Governador e do Vice-Governador; $(d)$ autorizem intervenção estadual em Município (art. 126). Além dessas matérias, o Regimento Interno da Assembléia Legislativa do Estado de São Paulo disciplina a utilização do projeto de decreto legislativo para aprovação de Conselheiros do Tribunal de Contas (art. 250); contas anuais do Tribunal de Contas (art. 20, XXVI, da CE); sustação de execução de contrato considerado irregular pelo Tribunal de Contas (art. 239); sustação de atos normativos do Poder Executivo que exorbitem do poder regulamentar ou dos limites de delegação legislativa; autorização de referendo e convocação de plebiscito (art. 20, XVIII, da $\mathrm{CE}$ ); destituição do Procurador-Geral de Justiça, antes do término do mandato (art. 20, XXIII, da CE); proposta de emenda à Constituição Federal; reconhecimento de calamidade pública decretada por Prefeito, para os fins do disposto no art. 65 da Lei de Responsabilidade Fiscal (LC n. 101/2000).

O constituinte mineiro fez tabula rasa da natureza diversa do decreto legislativo confrontada com a da resolução, e não previu no processo legislativo de Minas Gerais o projeto de decreto legislativo. De modo que todas as matérias de competência exclusiva do Legislativo e que se destinam, em sua regulação, a produzir efeitos externos são efetivadas mediante projeto de resolução.

\subsubsection{Projeto de Resolução}

Os projetos de resolução destinam-se a regular, com eficácia de lei ordinária, sem sanção do Governador, matéria de competência exclusiva da Assembléia Legislativa, de caráter político, processual, legislativo ou administrativo, ou quando deva a Assembléia pronunciar-se em caso concreto, tal como, a perda de mandato parlamentar. Mediante lei cria-se cargo novo para o Quadro de sua Secretaria e mediante lei fixa-se a remuneração ou qualquer alteração de remuneração dos cargos de seu Quadro, mas o aumento do número de cargos, já criados por lei, pode se dar mediante resolução, eis que possuem eficácia de lei ordinária, e compete às Assembléias Legislativas, por expressa previsão da Constituição Federal, dispor sobre os serviços administrativos de sua Secretaria e prover os respectivos cargos (art. 27, § $3^{\circ}$, da CF). 
Os Regimentos Internos das Assembléias Legislativas têm assento na Constituição Federal (art. 27, § $3^{\circ}$ ), que lhes confere competência para elaborar os respectivos Regimentos. Essa atribuição é efetivada mediante Resolução. Notadamente em matéria de processo legislativo é comum a constitucionalização de normas regimentais que, evidentemente, passam a ter estatura constitucional e às normas constitucionais o Regimento fica adstrito. No entanto, observa José Afonso da Silva, na relação entre lei e Regimento Interno "nenhum dos dois tipos de normas está acima do outro, porque não se trata de aplicar o princípio da hierarquia das normas, mas o princípio da competência. Trata-se de reconhecer uma reserva constitucional do regimento interno e, dentro dessa reserva, ele é soberano. Se a lei penetrar nele, ela se revelará inconstitucional. E, ao contrário, se o regimento interno extrapolar o âmbito que lhe foi reservado, ele é que padecerá de inconstitucionalidade". ${ }^{189}$ Por isso mesmo, zelando pela preservação de suas competências e de sua independência, o Poder Legislativo deve criar, e.g., as suas comissões permanentes sempre mediante resolução, jamais por lei. Notadamente comissão de fiscalização e controle dos atos do Poder Executivo, incluindo também os da Administração descentralizada, como ocorreu em São Paulo; submetendo-se ao crivo da conveniência do Executivo anuir (sanção), ou não (veto), com a criação de órgão interno do Legislativo destinado ao controle e fiscalização do próprio Poder Executivo. ${ }^{190}$

A Constituição de Minas Gerais adota somente a Resolução, prescindindo do Decreto Legislativo. Ao dispor sobre a normatização do projeto de resolução, o Regimento Interno da Assembléia Legislativa de Minas Gerais preconiza que ele se destina a regular matéria da competência privativa da Assembléia, aplicando-se a eles as disposições relativas ao projeto de lei ordinária (arts. 194 e 195). Singular, todavia, a atribuição regimental ao Presidente da Assembléia mineira de impugnar, no prazo de quinze dias úteis, projeto já aprovado pelo Plenário, desde que o faça motivadamente, afeiçoando-se à atribuição de veto do Governador concernente a projeto de lei. ${ }^{191}$ No

\footnotetext{
${ }^{189}$ Processo constitucional de formação das leis. 2. ed. São Paulo: Malheiros, 2006, p. 344.

${ }^{190}$ Lei n. 4.595, de 18 de junho de 1985 (Dispõe sobre a fiscalização, pela Assembléia Legislativa, dos atos do Poder Executivo, inclusive os da Administração indireta), alterada pelas Leis n. 5.318, de 23 de setembro de 1986, e n. 7.965, de 22 de julho de 1992.

191 “Art. 197 - O Presidente da Assembléia, no prazo [de quinze dias úteis], poderá impugnar motivadamente o projeto de resolução ou parte dele, hipóteses em que a matéria será devolvida a exame do Plenário.

"Art. 198 - A matéria não promulgada será incluída em Ordem do Dia, no prazo de 48 horas, para deliberação do Plenário em 10 dias.

$\S 1^{\circ}$ - Esgotado o prazo estabelecido neste artigo, sem deliberação, a matéria permanecerá na pauta, observado o disposto no $\S 3^{\circ}$ do art. 222 [sobrestamento das demais matérias].

$\S 2^{\circ}$ - Se a impugnação não for mantida, a matéria será promulgada no prazo de 48 horas."
} 
entanto, se o Plenário não se manifestar sobre a impugnação, no prazo de 10 dias, fíca mantido o projeto de resolução que já houvera sido aprovado pelo próprio Plenário, impondo-se, então, a sua promulgação pelo Presidente e, se este não o fizer, caberá ao Vice-Presidente fazê-lo.

\subsection{Titulares de iniciativa legislativa nos Estados}

Nada obstante as Constituições Federais, até a de 1988, terem mantido com rigor apenas os pressupostos da democracia representativa no processo legislativo, há precedentes no Direito Constitucional Estadual da participação direta do povo no processo de formação das leis estaduais. Tome-se o que preconizava a Constituição riograndense-do-sul, de 25 de abril de 1891, em vigor a partir de 14 de julho deste mesmo ano, que permitia a participação de "qualquer cidadão habitante do Estado" no processo legislativo, mediante formulação de "emendas" ou "observações", no período de 3 meses, aos projetos que seriam promulgados ou vetados pelo Presidente do Estado gaúcho (art. 32). A Constituição do Estado de Minas Gerais, de 14 de julho de 1947, também contemplava a participação popular. A titularidade da iniciativa de projeto de lei podia ser efetivada diretamente pelo povo, desde que houvesse subscrição de dez mil eleitores a projeto de lei (art. 27, IV).

A Constituição Federal de 1988 não se manteve infensa ao estabelecimento de pressuposto da democracia direta no processo legislativo federal (arts. 14, III, e 61, $\S 2^{\circ}$ ), nem ao estadual. Em capítulo dedicado aos Estados Federados (arts. 25-28), o constituinte originário determinou que "a lei disporá sobre a iniciativa popular no processo legislativo estadual" (art. $27, \S 4^{\circ}$ ). Evidente que não se trata de lei nacional, a estandardizar a iniciativa popular no processo legislativo estadual em padrões préestabelecidos pelo Congresso Nacional. Ao determinar que a lei deva dispor sobre a iniciativa popular no processo legislativo estadual, o constituinte federal indicou aos constituintes estaduais a necessidade de se prever, nas Constituições Estaduais, a adoção desta técnica da democracia direta, participativa, de modo que, ao disciplinar o respectivo processo legislativo, os constituintes de cada Estado-membro deveriam adotar também este titular de iniciativa, em clara indicação de rompimento com a exclusividade de apenas os representantes disporem da competência de deflagração no processo de formação das leis. Os constituintes estaduais não só observaram este comando, como também, em alguns casos, previram a possibilidade de, além da 
iniciativa popular em projetos de lei, ser possível a iniciativa popular para proposta de emenda à Constituição Estadual.

É o que se constata em 14 (quatorze) Constituições Estaduais ${ }^{192}$, que prevêem a iniciativa popular para apresentação de proposta de emenda à respectiva Constituição Estadual: Acre (art. 53, III, e $\S 5^{\circ}$, que remete à lei complementar a normatização da matéria); Alagoas, por 1\% (um por cento) do eleitorado estadual, distribuído em, pelo menos, um quinto dos Municípios do Estado (art. 85, IV); Amapá, mediante subscrição de, no mínimo, 1\% (um por cento) do eleitorado do Estado (art. 103, IV); Amazonas, com assinatura de, no mínimo, 5\% (cinco por cento) do eleitorado estadual, distribuído, ao menos, em $25 \%$ (vinte e cinco por cento) dos Municípios do Estado, e não inferior a $5 \%$ (cinco por cento) dos eleitores de cada um dos Municípios (art. 32, IV); Bahia, desde que subscrita por, no mínimo, $1 \%$ (um por cento) do eleitorado do Estado (art. 74, IV); Espírito Santo, mediante proposta de, no mínimo, $1 \%$ (um por cento) do eleitorado estadual, distribuído em pelo menos 5 (cinco) Municípios com um mínimo de $2 \%$ (dois por cento) dos eleitores de cada um dos respectivos Municípios (arts. 62, III, e 69); Goiás, desde que subscrita por, no mínimo, $1 \%$ (um por cento) do eleitorado do Estado, dispostos em 20 (vinte) Municípios (art. 19, IV); Pará, assinada por 0,5\% (meio por cento) do eleitorado do Estado (arts. $8^{\circ}$ e 103, V); Paraíba, subscrita por, no mínimo, $1 \%$ (um por cento) do eleitorado do Estado (art. 62, IV); Pernambuco, mediante subscrição de, no mínimo, 1\% (um por cento) do eleitorado estadual, distribuído, pelos menos, em um quinto dos Municípios e com não menos de três décimos por cento dos eleitores de cada um deles (art. 17, III); Rio Grande do Sul, tomada por $1 \%$ (um por cento) do eleitorado que tenha votado nas últimas eleições gerais do Estado, distribuído, no mínimo, em um décimo dos Municípios, com não menos de meio por cento dos eleitores de cada um deles (arts. 58, IV, e 68); Roraima, mediante assinatura de 5\% (cinco por cento) dos eleitores do Estado (art. 39, IV); Santa Catarina, com participação de, pelo menos, 2,5\% (dois e meio por cento) do eleitorado estadual, distribuído por, no mínimo, quarenta Municípios, com não menos de um por cento dos eleitores de cada um deles (art. 49, IV); São Paulo, mediante assinatura de, ao menos, $1 \%$ dos eleitores do Estado (art. 22, IV); e Sergipe, pela assinatura de, no mínimo, $1 \%$ (um por cento) do eleitorado do Estado (art. 55, IV).

\footnotetext{
${ }^{192}$ Pesquisa efetuada em julho de 2007.
} 
Observe-se que a Constituição Federal não contempla os cidadãos como titulares de iniciativa de proposta de emenda constitucional. Estariam, então, todas as Constituições Estaduais, que prevêem esta hipótese, incorrendo em manifesta inconstitucionalidade, já que em desconformidade com o modelo de processo legislativo estatuído pela Constituição Federal? Ou as Constituições Estaduais, de forma vanguardeira, estariam a observar, nessa previsão, o próprio fundamento da soberania popular ("todo o poder emana do povo"), insculpido no artigo primacial da Constituição Federal e sobre o qual se constitui em Estado Democrático de Direito a República Federativa do Brasil? Diz-se "em vanguarda" apenas para registro de que a Ordem dos Advogados do Brasil tem solicitado às Assembléias Legislativas que patrocinem proposta de emenda à Constituição Federal, com fundamento no artigo 60, III, para que se inclua nesse próprio artigo 60, um novo inciso, o IV, com a finalidade de assegurar também à iniciativa popular a titularidade para propor alteração à Constituição Federal: “A Constituição poderá ser emendada mediante proposta: (...) IV- de um por cento do eleitorado nacional, distribuído pelo menos por cinco Estados, com três décimos por cento dos eleitores de cada um deles". ${ }^{193}$

A iniciativa popular para apresentação de projetos de lei é um tipo de iniciativa compartilhada e encontra limitação em relação às matérias já reservadas à iniciativa exclusiva de outros titulares. A Constituição paulista não deixou pressuposto esse limite, pois foi expressa. ${ }^{194}$ Os projetos de lei de iniciativa popular não podem dispor sobre qualquer matéria já exclusivamente reservada para iniciativa da Assembléia Legislativa, do Governador, do Tribunal de Justiça, do Tribunal de Contas e do Ministério Público. O Regimento Interno da Assembléia do Estado do Tocantins, e.g., dispondo sobre o processamento da iniciativa popular de projeto de lei, à semelhança do que prevê o artigo 252 do Regimento Interno da Câmara dos Deputados, estabelece em seu artigo 247: (a) que não se rejeitará, liminarmente, o projeto por vícios de linguagem, lapsos ou imperfeições de técnicas legislativas, incumbindo-se a

\footnotetext{
${ }^{193}$ Of. Circular n. 013/CEAEC/GAC, de 16 de setembro de 2008, dirigido à Assembléia Legislativa de São Paulo e subscrito pelo Presidente do Conselho Federal da OAB, Dr. Cezar Britto, e pelo Presidente da Comissão de Apoio à Emenda Constitucional de Iniciativa Popular, Prof. Paulo Bonavides. "Informamos que pela vez primeira em nossa história constitucional, se obtivermos o apoio desta Colenda Casa (e de mais 13 irmãs de Federação), o Congresso apreciará proposta de emenda advinda da união das vontades democráticas das Assembléias Estaduais. De sorte que esse será outro fato histórico a legitimar e a coroar de brilho cometimento de tamanha envergadura que partirá dos Órgãos Legislativos Estaduais.”

194 "Não serão suscetíveis de iniciativa popular matérias de iniciativa exclusiva, definidas nesta Constituição." (art. 24, § 3º, item 5, da Constituição do Estado de São Paulo)
} 
Comissão de Constituição, Justiça e Redação de escoimá-lo dos vícios formais para sua regular tramitação; (b) a Mesa designará parlamentares para exercer, em relação ao projeto, os poderes ou atribuições conferidas pelo Regimento ao autor de proposição, devendo a escolha recair sobre quem tenha sido, com a sua anuência, previamente indicado com essa finalidade pelo primeiro cidadão signatário do projeto; (c) assinatura de cada eleitor deverá ser acompanhada de seu nome completo e legível, endereço e dados identificadores de seu título eleitoral; (d) as listas de assinaturas serão organizadas por Município, em formulário padronizado e fornecido pela Mesa da Assembléia; (e) será lícito à entidade da sociedade civil patrocinar a apresentação de projeto de lei de iniciativa popular, responsabilizando-se, inclusive, pela coleta das assinaturas; (f) o projeto será instruído com documento hábil da Justiça Eleitoral quanto ao contingente de eleitores alistados em cada Município, aceitando-se, para esse fim, os dados referentes ao ano anterior, se não disponíveis outros mais recentes; (g) depois de protocolizado, verificar-se-á o cumprimento das exigências constitucionais para sua apresentação; (h) o projeto de lei terá a mesma tramitação dos demais, integrando sua numeração geral; (i) nas Comissões poderá usar da palavra para discutir o projeto de lei, pelo prazo de dez minutos, o primeiro signatário, ou quem este tiver indicado, quando da apresentação do projeto; (j) cada projeto deverá circunscrever-se a um mesmo assunto, podendo, caso contrário, ser desdobrado pela Comissão de Constituição e Justiça em proposições autônomas, para tramitação em separado.

A Constituição do Rio Grande do Sul, ao prever a hipótese de rejeição pela Assembléia Legislativa de projeto de lei de iniciativa popular, determina que ele "será submetido a referendo popular se, no prazo de cento e vinte dias, dez por cento do eleitorado que tenha votado nas últimas eleições gerais do Estado o requerer" (art. 68, § $\left.3^{\circ}\right)$.

A Constituição do Estado do Pará concedeu também ao "Tribunal de Justiça, após aprovação pela maioria dos desembargadores" (art. 103, III), competência para deflagrar o processo legislativo de proposta de emenda à Constituição Estadual. É iniciativa compartilhada com um terço, no mínimo, dos membros da Assembléia Legislativa; com o Governador e com mais da metade das Câmaras de Vereadores dos Municípios do Estado, manifestando-se, cada uma delas, pela maioria relativa de seus membros. 
Trata-se de atribuição somente concedida pelo constituinte estadual paraense e não guarda nenhuma simetria com os titulares deste mesmo direito estatuído na Constituição Federal, que a reserva apenas para (a) um terço, no mínimo, dos membros da Câmara dos Deputados ou (b) do Senado, para (c) o Presidente da República, (d) e a mais da metade das Assembléias Legislativas das unidades da Federação (art. 60, I, II e III).

Com a mesma singularidade, isto é, não observando os mesmos paradigmas previstos na Constituição Federal, exige-se subscrição de, no mínimo, 2/3 (dois terços), dos membros da Assembléia Legislativa de Roraima para se outorgar titularidade em ordem a apresentação de proposta de emenda àquela Constituição Estadual (art. 39, I).

De igual viés restritivo ao fixado pela Constituição roraimense, a do Estado do Rio Grande do Norte privilegiou unicamente dois titulares com capacidade para propor emenda constitucional: o Governador e 1/3 (um terço), no mínimo, dos membros da Assembléia Legislativa (art. 45, I e II).

Note-se, ainda, que a conjuntos diferentes de Câmaras Municipais concedese a titularidade para apresentação de proposta de emenda à Constituição Estadual. Assim, no Rio Grande do Sul exige-se que haja iniciativa conjunta de 1/5 (um quinto) dos Legislativos municipais (art. 58, III); em São Paulo, Paraná, Paraíba, Piauí e Espírito Santo, somente a reunião conjunta de mais de 1/3 (um terço) das Câmaras Municipais pode iniciar procedimento legislativo para alteração da Constituição do Estado (art. 22, III; art. 64, III; art. 62, III; art. 74, III; art. 62, IV, respectivamente); em Tocantins, $3 / 5$ [três quintos (art. 26, III)]; e em Minas Gerais a Constituição Estadual pode ser emendada por proposta de, no mínimo, 100 (cem) Câmaras Municipais (art. 64, III).

Referentemente a iniciativa das leis estaduais, as Constituições Estaduais estabelecem, com pequenas variações, que são titulares qualquer membro ou comissão da Assembléia Legislativa, Governador do Estado, Tribunal de Justiça, Tribunal de Contas do Estado, Tribunal de Contas dos Municípios, Procurador-geral de Justiça e os cidadãos, na forma e nos casos previstos pelas respectivas Constituições.

A titularidade da iniciativa legislativa e a sistemática de reservar específicas matérias a específicos titulares estabelecida pelas Constituições Estaduais geram, por 
conseguinte, privativa capacidade de iniciativa desses titulares para deflagrar o processo legislativo nessas matérias reservadas.

A iniciativa legislativa reservada insere-se como tema do princípio da separação de poderes e ao constituinte estadual, ex vi do disposto no artigo 25 da Constituição Federal e no artigo 11 do seu ADCT, não cabe preteri-la, notadamente quanto à observância dos padrões e iniciativa reservada adotados pela Constituição Federal no processo legislativo federal. Ao vincular a reserva de iniciativa de determinadas matérias a determinados titulares, a Constituição Federal dá modelagem para sistematizar, quanto a esse aspecto, o princípio da separação de poderes. E os Estados-membros estão adstritos aos padrões dessa sistematização da iniciativa legislativa, como corolário do princípio da separação de poderes. Nesse sentido sustenta Raul Machado Horta que "a precedência lógico-jurídica do constituinte federal, na organização originária da Federação, torna a Constituição Federal a sede de normas centrais, que vão conferir homogeneidade aos ordenamentos parciais constitutivos do Estado Federal, seja no plano constituinte, no domínio das Constituições Estaduais, seja na área subordinada da legislação ordinária”. ${ }^{195}$

Anote-se, a propósito, que a nenhum dos titulares de iniciativa a Constituição Federal conferiu competência para deflagrar o processo legislativo sobre toda e qualquer matéria; não há, pois, um titular de iniciativa geral, vez que, excetuando a iniciativa popular, a todos (art. 61, caput) o constituinte acabou por conceder, sobre alguma matéria, privativa competência para iniciar o seu processo legislativo, vale dizer, com redundância, para começar o processo legislativo da matéria na qual lhe foi reservada a iniciativa. Muito embora o mencionado dispositivo seja considerado como aquele que disciplinaria a iniciativa geral, ela não existe no processo legislativo federal e nem no estadual, em observância também ao princípio da separação de poderes. É o que se constata em todas as Constituições Estaduais: Acre (art. 54); Alagoas (art. 86); Amapá (art. 104); Amazonas (art. 33); Bahia (art. 75); Ceará (art. 60); Espírito Santo (art. 63); Goiás (art. 20); Maranhão (art. 42); Mato Grosso (art. 39); Mato Grosso do Sul (art. 67); Minas Gerais (art. 65); Pará (art. 104); Paraíba (art. 63); Paraná (art. 65); Piauí (art. 75); Pernambuco (art. 19); Rio de Janeiro (art. 112); Rio Grande do Norte (art. 46); Rio Grande do Sul (art. 59); Rondônia (art.

\footnotetext{
${ }^{195} R D P$, Poder constituinte do Estado-membro, n. 88, p. 6.
} 
39); Roraima (art. 41); Santa Catarina (art. 50); São Paulo (art. 24); Sergipe (art. 59) e Tocantins (art. 27).

Desde que incluídos como titulares de iniciativa no processo legislativo estadual os equivalentes aos que a Constituição Federal outorga esse direito no processo federal (Parlamentares e Comissão Parlamentar; Presidente da República/Governador; Tribunais Superiores/Tribunal de Justiça ${ }^{196}$; Procurador-Geral da República/Procurador-Geral de Justiça; cidadãos), podem os Estados, efetivando sua capacidade de auto-organização, ampliar o rol dos titulares de iniciativa legislativa. Zeloso dessa sua autonomia, o constituinte gaúcho concedeu também às Câmaras Municipais o poder de iniciar o processo legislativo estadual (art. 59). Com efeito, não tendo elas, como os cidadãos, competência reservada, subsumem-se à restrição de que não serão suscetíveis da iniciativa popular nem da iniciativa das Câmaras Municipais as matérias de iniciativa exclusiva, definidas na Constituição Estadual. É, outrossim, a coibição que faz a Constituição paulista, referentemente à iniciativa popular (art. $24, \S 3^{\circ}$, item 5).

Não obstante detenham titularidade para deflagrar o processo legislativo estadual, aos Tribunais de Justiça, Procuradores-Gerais de Justiça e Tribunais de Contas não se reconhece o direito da iniciativa concorrente com os demais titulares em matérias não timbradas pela reserva de iniciativa. A iniciativa concorrente para deflagrar o processo de feitura de leis em matérias não reservadas à iniciativa exclusiva é a partilhada somente pelos parlamentares estaduais, Comissões da Assembléia Legislativa, Governador do Estado, iniciativa popular e, no caso do Rio Grande do Sul, pelas Câmaras Municipais também.

\section{A atribuição concedida aos Procuradores-Gerais de Justiça para} apresentar projeto de lei complementar dispondo sobre organização, atribuições e o estatuto do Ministério Público Estadual perante as Assembléias Legislativas, reveste-se de caráter facultativo e deflui de expressa disposição da própria Constituição Federal (art. 128, $\S 5^{\mathrm{o}^{197}}$ ). O respectivo Procurador-Geral de Justiça pode iniciar o processo legislativo estadual da aludida matéria, mas não lhe foi concedida exclusividade.

\footnotetext{
${ }^{196}$ Os Tribunais de Contas do Estado e os Tribunais de Contas dos Municípios do Estado por força do art. 75 combinado com o art. 96, II, da Constituição Federal, que garantem o poder de "propor ao Poder Legislativo respectivo" matéria que especifica.

197 “Art. 128 - (...) § 5 - Leis complementares da União e dos Estados, cuja iniciativa é facultada aos respectivos Procuradores-Gerais, estabelecerão a organização, as atribuições e o estatuto de cada Ministério Público, observadas, relativamente a seus membros: (...)"
} 
Paradoxalmente, norma constitucional federal indica ser de competência privativa do Presidente da República e, pois, dos respectivos Governadores, a iniciativa das leis que disponham sobre organização do Ministério Público (art. $61, \S$ 'o, II, $d$ ). Se a matéria é de iniciativa legislativa exclusiva, não poderia ser compartilhada, mas o foi. Esta aparente antinomia de normas constitucionais resolve-se com a óbvia constatação de que o constituinte excepcionou, nesta matéria, a exclusividade concedida.

Da mesma forma se dá com as Constituições Estaduais quando assim também dispõem sobre a matéria. Os Governadores dos Estados deteriam a competência exclusiva para iniciar o processo legislativo sobre a organização do Ministério Público Estadual, porém facultou-se idêntica iniciativa aos ProcuradoresGerais de Justiça. Desta forma, quando houver conflitos de iniciativa nesta matéria, para José Afonso da Silva "prevalece a iniciativa primeira, com efeitos diferentes entre ambas". ${ }^{198}$ De acordo com a solução vislumbrada pelo eminente jurista e, mutatis mutandis, aplicada no âmbito do processo legislativo estadual, se o Procurador-Geral de Justiça tomar a iniciativa, antes do Governador do Estado, prevalece a iniciativa daquele. Se ainda assim o Governador do Estado superpuser sua iniciativa à do Procurador-Geral de Justiça, o eventual conflito se harmonizará nos termos de normas regimentais, que possibilitam a anexação da segunda proposição à primeira, tramitando ambas juntas. Acompanhando, ainda, a solução de José Afonso da Silva, há ponderação para que, de plano, o Presidente da Assembléia Legislativa não recuse o seguimento da proposta do Governador do Estado. No entanto, o inverso não é verdadeiro. Ou seja, se o Governador do Estado tomar a iniciativa, esta prevalecerá, porque não se admite iniciativa superposta do Procurador-Geral de Justiça, porque, ainda com José Afonso da Silva, este só detém uma faculdade, uma autorização, para dar início à lei; o Governador, ao contrário, tem o poder de iniciativa com nota de privaticidade, e se ele já tomou a iniciativa da lei complementar, a faculdade do Procurador-Geral de Justiça fica afastada.

Afirmou-se, acima, que os Governadores de Estado deteriam competência exclusiva para iniciar o processo legislativo sobre a organização do Ministério Público Estadual, ex vi do art. 128, § $5^{\circ}$, da Constituição Federal. Todavia, as Constituições Estaduais de Alagoas (art. 86, § $1^{\circ}$, II, $d$ ), Amazonas (art. 33, § $1^{\circ}, d$ ), Bahia (art. 77), Ceará (art. 60, $\S 2^{\circ}$ ), Goiás (art. 20, $\S 1^{\circ}$ ), Maranhão (art. 43), Mato Grosso do Sul (art.

${ }^{198}$ Processo constitucional de formação das leis. 2. ed., São Paulo: Malheiros, 2006, p. 159-160. 
67, § $1^{\circ}$ ), Minas Gerais (art. 66, III), Pará (art. 105), Paraná (art. 66), Rio Grande do Norte (art. 46, § $1^{\circ}$, II), Rio Grande do Sul (art. 60), Santa Catarina (art. 50, § $2^{\circ}$ ) e São Paulo $^{199}$ não acompanharam a reserva de iniciativa legislativa para o Governador nesta matéria. Nesse caso, então, seria a iniciativa facultada aos respectivos ProcuradoresGerais de Justiça, mas exercida concorrentemente com qualquer membro do Legislativo, Comissão Parlamentar, cidadãos e, no Rio Grande do Sul, compartilhada também com as Câmaras Municipais? Ou teriam os Procuradores-Gerais de Justiça iniciativa exclusiva? Evidente que, se a iniciativa foi-lhes outorgada como faculdade, exclusividade não há.

Constata-se também, no processo legislativo do poder constituinte decorrente, como é o dos Estados da Federação brasileira, que o rol dos titulares de iniciativa para propor emenda constitucional sofreu modulações em relação ao padrão estabelecido pelo constituinte originário (art. 60, I a III, da CF).

Como já se informou, a Constituição do Estado do Pará concedeu também ao “Tribunal de Justiça, após aprovação pela maioria dos desembargadores” (art. 103, III), a titularidade para deflagrar o processo legislativo de proposta de emenda à Constituição Estadual. Além deste novo titular, que não encontra simetria na Constituição Federal, a iniciativa popular para propor alteração na Constituição Federal, também ignorada pelo constituinte originário, mereceu de vários constituintes estaduais o poder desta titularidade. É o que se constata, ao menos, em 14 (quatorze) Constituições Estaduais, que prevêem a iniciativa popular para apresentação de proposta de emenda à respectiva Constituição Estadual

A questão recorrente e tema central da tese aqui investigada vem a lume de novo: a relação dos titulares de iniciativa para propor emendas à Constituição Federal é de observância obrigatória para os Estados-membros? Devem as Constituições Estaduais conformação rigorosamente simétrica com o paradigma federal nesta matéria? Parece que não, principalmente porque essa matéria não é principiológica; trata-se de regra da norma que fixou um processo para mudança constitucional, esta sim fulcral, principiológica, corolário da concepção de uma Constituição mutável, exceto em relação ao seu cerne fixo, inabolível (art. 60, $\S 4^{\circ}$ ). Por quem pode ser

\footnotetext{
199 “Art. $24-(\ldots) \S 2^{\circ}$ - Compete exclusivamente ao Governador do Estado a iniciativa das leis que disponham sobre: (...) 3 - organização da Procuradoria Geral do Estado e da Defensoria Pública do Estado, observadas as normas gerais da União."
} 
proposta a mudança não é questão absolutamente inalterável, o essencial é a previsão de um processo de alteração constitucional. Daí aos Estados-membros, no exercício do poder de auto-organização e observando os princípios da Constituição Federal, sem ferir a rigidez do processo de alteração constitucional, ser facultada a opção de incluir outros titulares, além dos previstos pelo processo legislativo federal, no rol dos competentes para propor emenda constitucional estadual.

\subsection{Titulares de emenda}

A titularidade e a oportunidade de emendas às proposições principais é matéria disciplinada pelos Regimentos Internos. Norma regimental pode atribuir a parlamentar, individualmente; a um conjunto de parlamentares; à Comissão permanente; ou até à iniciativa popular o direito de apresentar emendas às proposições principais. Indica, outrossim, o momento de sua apresentação: se no período de Pauta, se perante às Comissões, ou em Plenário. Além destes, aos próprios detentores da iniciativa legislativa (Governador, Tribunais e Ministério Público) admite-se a possibilidade de propor, até determinado momento do iter legislativo, alteração às respectivas propostas originais. As alterações assim ofertadas pelo Executivo denominam-se "mensagem aditiva" (Assembléia paulista - praxe) ou "mensagem retificativa” (art. 198 do Regimento Interno da Assembléia gaúcha).

Impende-se que se sublinhe que a Constituição Federal não veda a apresentação de emendas, pelos parlamentares e por Comissões técnicas permanentes, a projetos em tramitação, antes a reconhece como direito ínsito à atividade legislativa. Veda, no entanto, o aumento de despesa originariamente prevista em projetos de iniciativa exclusiva do Executivo e em projetos sobre organização dos serviços administrativos do Legislativo, Tribunais e Ministério Público, o que, à evidência, se efetiva mediante apresentação de emenda e sua conseqüente aprovação pelo Plenário (art. 63, I e II, da CF). Ao projeto de lei do orçamento anual, o constituinte de 1988, prestigiando a atuação de parlamentar - que no ordenamento constitucional imediatamente anterior assistia de mãos atadas a aprovação, por decurso de prazo, em data marcada, 30 de novembro, do inteiro teor do projeto original ${ }^{200}$ - admitiu, expressamente, aprovação, pelo Plenário, de emendas que não sejam incompatíveis

200 “Art. 66. O projeto de lei orçamentária anual será enviado pelo Presidente da República ao Congresso Nacional, para votação conjunta das duas Casas, até quatro meses antes do início do exercício financeiro seguinte; se, até trinta dias antes do encerramento do exercício financeiro, o Poder Legislativo não o devolver para sanção, será promulgado como lei." 
com o plano plurianual e com a lei de diretrizes orçamentárias, e desde que se indiquem os recursos necessários, admitidos apenas os provenientes de anulação de despesa, excluídas as que incidam sobre dotações para pessoal e seus encargos, serviço da dívida, transferências tributárias constitucionais.

De modo que, excluídas as limitações referenciadas, não há falar em impedimento à apresentação de emenda - tanto por parlamentares como por Comissão - a qualquer projeto, tampouco à aprovação delas pelo Legislativo. Esse o entendimento do Supremo Tribunal Federal, inclusive para o processo legislativo estadual:

— "O projeto de lei sobre organização judiciária pode sofrer emendas parlamentares de que resulte, até mesmo, aumento da despesa prevista. O conteúdo restritivo da norma inscrita no art. 63, II, da Constituição Federal, que concerne exclusivamente aos serviços administrativos estruturados na secretaria dos tribunais, não se aplica aos projetos referentes à organização judiciária, eis que as limitações expressamente previstas, nesse tema, pela Carta Política de 1969 (art. $144, \S 5^{\circ}$, in fine), deixaram de ser reproduzidas pelo vigente ordenamento constitucional." (ADI 865-MC, Rel. Min. Celso de Mello, julgamento em 7-10-93, DJ 8-4-94)

— "Matérias de iniciativa reservada: as restrições ao poder de emenda ficam reduzidas à proibição de aumento de despesa e à hipótese de impertinência da emenda ao tema do projeto. Precedentes do STF: RE 140.542-RJ, Galvão, Plenário, 30-9-93; ADIn 574, Galvão; RE 120.331CE, Borja, DJ 14-12-90; ADIn 865-MA, Celso de Mello, DJ 8-4-94." (RE 191.191, Rel. Min. Carlos Velloso, julgamento em 12-12-97, DJ 20-2-98)

- "A atuação dos membros da Assembléia Legislativa dos Estados achase submetida, no processo de formação das leis, à limitação imposta pelo art. 63, I, da Constituição, que veda - ressalvadas as proposições de natureza orçamentária - o oferecimento de emendas parlamentares de que resulte o aumento da despesa prevista nos projetos sujeitos ao exclusivo poder de iniciativa do Governador do Estado. O exercício do poder de emenda, pelos membros do parlamento, qualifica-se como prerrogativa inerente à função legislativa do estado. $O$ poder de emendar - que não constitui derivação do poder de iniciar o processo de formação das leis - qualifica-se como prerrogativa deferida aos parlamentares, que se sujeitam, no entanto, quanto ao seu exercício, às restrições impostas, em numerus clausus, pela Constituição Federal. A Constituição Federal de 1988, prestigiando o exercício da função parlamentar, afastou muitas das restrições que incidiam, especificamente, no regime constitucional anterior, sobre o poder de emenda reconhecido aos membros do Legislativo. O legislador constituinte, ao assim proceder, certamente pretendeu repudiar 
a concepção regalista de Estado (RTJ 32/143 - RTJ 33/107 — RTJ 34/6 - RTJ 40/348), que suprimiria, caso prevalecesse, o poder de emenda dos membros do Legislativo. Revela-se plenamente legítimo, desse modo, o exercício do poder de emenda pelos parlamentares, mesmo quando se tratar de projetos de lei sujeitos à reserva de iniciativa de outros órgãos e Poderes do Estado, incidindo, no entanto, sobre essa prerrogativa parlamentar — que é inerente à atividade legislativa -, as restrições decorrentes do próprio texto constitucional (CF, art. 63, I e II), bem assim aquela fundada na exigência de que as emendas de iniciativa parlamentar sempre guardem relação de pertinência com o objeto da proposição legislativa. Doutrina. Precedentes." (ADI 973-MC, Rel. Min. Celso de Mello, julgamento em 17-12-93, DJ de 19-12-06)

— "Processo legislativo da União: observância compulsória pelos Estados de seus princípios básicos, por sua implicação com o princípio fundamental da separação e independência dos poderes: jurisprudência do Supremo Tribunal. Processo legislativo: emenda de origem parlamentar a projeto de iniciativa reservada a outro poder: inconstitucionalidade, quando da alteração resulte aumento da despesa consequiente ao projeto inicial (...)." (ADI 774, Rel. Min. Sepúlveda Pertence, julgamento em 10-12-98, DJ 26-2-99). No mesmo sentido: ADI 816, Rel. Min. Ilmar Galvão, julgamento em 22-8-96, DJ 27-9-96; ADI 2.840-QO, Re. Min. Ellen Gracie, julgamento em 15-10-03, DJ 11-6-04; ADI 805, Rel. Min. Sepúlveda Pertence, julgamento em 17-12-98, DJ 12-3-99; ADI 2.079, Rel. Min. Mauricio Corrêa, julgamento em 29-4-04, DJ 18-6-04.

Reafirme-se, pois, que a prerrogativa de apresentar emendas às proposições em trâmite constitui direito do parlamentar inerente às atividades legislativas do mandato representativo, podendo o mandatário oferecê-las mesmo quando se tratar de projetos timbrados pela reserva de iniciativa; nesse caso, observar-se-ão apenas as restrições constitucionais supra mencionadas. Ao Plenário, evidentemente, compete aprová-las, para que se tornem emendas do Legislativo à proposição. 


\section{CAP. 6 PROCEDIMENTOS LEGISLATIVOS}

Os Regimentos Internos das Casas Legislativas prevêem ritos para a consecução do processo legislativo; dizem respeito a procedimentos legislativos e referem-se à maneira sucessiva como as fases processuais se desenvolvem, à dinâmica do processo legislativo. A inobservância das formalidades previstas nos procedimentos legislativos pode ensejar vícios regimentais e, pois, a declaração de inconstitucionalidade da norma produzida, eis que há preceito constitucional estabelecendo que a aprovação das proposições dar-se-á "na forma regimental”. É o que expressamente determinam as Constituições do Estado de São Paulo (art. 28, caput), Paraíba (art. 65, caput), Roraima (art. 43, caput) e Amapá (art. 107, caput).

Mas, não obstante possuam nos Regimentos Internos sua fonte formal, os procedimentos legislativos abrigam também comandos constitucionais. Como condições de admissibilidade do procedimento de formação das leis, José Afonso da Silva enumera: “a) funcionamento do Legislativo; b) apresentação do projeto; c) existência de quorum para deliberar; d) Ordem do Dia". ${ }^{201}$ Sobre cada condição há análise específica no decorrer do estudo, com predominância para os procedimentos legislativos estaduais.

As condições de admissibilidade do procedimento de formação das leis, aplicam-se, outrossim, ao procedimento de formação das emendas constitucionais e, da mesma forma, ao procedimento de formação de resoluções e decretos legislativos, por determinação constitucional. É o que determina a Constituição do Estado de São Paulo, por exemplo, ao preceituar que o Regimento Interno da Assembléia Legislativa disciplinará os casos de decreto legislativo e de resolução cuja elaboração, redação, alteração e consolidação serão feitas com observância das mesmas normas técnicas relativas às leis (art. 27).

Do exame dos Regimentos Internos das Assembléias Legislativas podem-se identificar os seguintes procedimentos: $a$ ) procedimento legislativo padrão; $b$ ) procedimento legislativo abreviado; c) procedimento legislativo sumário; $d$ ) e procedimento legislativo especial.

${ }^{201}$ Processo constitucional de formação das leis. 2. ed., São Paulo: Malheiros, 2006, p. 261 


\subsection{Procedimento legislativo padrão}

O procedimento legislativo padrão destina-se à formação das leis ordinárias, excluídas as de criação de Municípios, os códigos e as leis do plano plurianual, das diretrizes orçamentárias e a do orçamento anual. Inicia-se com a protocolização do projeto e sua leitura em Plenário no Expediente da sessão, autuação, publicação e inclusão em pauta para recebimento de emendas. Com as respectivas emendas juntadas, o projeto prossegue sua tramitação nas Comissões permanentes a que tenha sido distribuído, para estudos e debates concernentes à legalidade, juridicidade e constitucionalidade; mérito financeiro-orçamentário, e mérito principal a cargo da Comissão de maior pertinência temática com o objeto da propositura. Com os pareceres exarados pelas Comissões, o projeto segue para o Plenário para discussão e votação. De regra, os projetos de lei sujeitam-se a turno único de discussão e votação. Porém, são dois os turnos no procedimento previsto pelos Regimentos Internos das Assembléias Legislativas da Bahia (art. 148), Ceará (art. 247), Espírito Santo (art. 174), Minas Gerais (art. 176), Mato Grosso do Sul (art. 266), Paraná (art. 142), Pernambuco (art. 218), Piauí (art. 142), Rio de Janeiro (art. 126) e Rondônia (art. 197). E o Regimento da Assembléia de Goiás estipula três turnos de discussão e votação (art. 157, $§ 1^{\circ}$ ). Ultimada a votação, sendo o projeto aprovado com alteração, receberá redação final da Comissão pertinente. Com aprovação ficta $^{202}$ ou expressa da redação proposta, o projeto será enviado, em autógrafo, para deliberação do Governador.

\subsection{Procedimento legislativo abreviado}

O procedimento legislativo abreviado contempla as Comissões em sede deliberante. Por ele, as Comissões discutem e votam projetos de lei que dispensarem, na forma do Regimento Interno, a competência do Plenário, salvo se houver, para decisão deste, requerimento de um décimo dos membros da Assembléia Legislativa. Na disciplina das matérias sobre quais Comissões têm competência para deliberar conclusivamente, os Regimentos Internos foram parcimoniosos, não se outorgando às Comissões todo e qualquer assunto. O Regimento Interno da Assembléia Legislativa de

\footnotetext{
${ }^{202}$ XIII Consolidação do Regimento Interno da Assembléia Legislativa do Estado de São Paulo:

“Art. 151 - Uma vez aprovados pelo Plenário (...) os projetos serão encaminhados à Comissão de Redação, para redigir o vencido.

$\S 1^{\circ}$ - A redação proposta pela Comissão será publica e o projeto incluído em Pauta, por 2 sessões, para recebimento de emendas.

$\S 2^{\circ}$ - Se forem apresentadas emendas [de redação], voltará o projeto à Comissão para parecer, após o que será incluído na Ordem do Dia para discussão e votação [da redação final].

$\S 3^{\circ}$ - Não havendo emendas, considerar-se-á aprovada a redação proposta."”
} 
São Paulo dispõe, em numerus clausus, sobre os projetos de lei que podem ser objeto de discussão e votação conclusiva por uma Comissão de mérito; são os que disponham sobre declaração de utilidade pública de associações civis; denominação de estabelecimentos ou próprios públicos; instituição de data comemorativa, ou oficialização de eventos festivos, assim como sua inclusão no calendário turístico do Estado (art. 33, II). Já o Regimento da Assembléia Legislativa do Rio Grande do Norte não enumera taxativamente as matérias sujeitas à decisão terminativa das Comissões permanentes, preferindo indicar que projeto de lei complementar, projeto de lei de iniciativa popular, projeto de lei em regime de urgência não se submetem a esse procedimento legislativo abreviado. Adverte, ainda, que quando houver manifestações divergentes das Comissões sobre a mesma proposição, sempre ao Plenário caberá deliberar (art. 124, II).

Despiciendo observar que a decisão de mérito da Comissão competente somente será final, se não houver requerimento de um décimo dos membros da Assembléia para que o Plenário profira a decisão definitiva. Por isso mesmo, há também norma regimental estipulando prazo para apresentação desse recurso ao Plenário, das matérias já deliberadas pelas Comissões. O Regimento Interno da Assembléia paulista fixa em três sessões, após a publicação do parecer conclusivo da Comissão, o prazo para oferecimento do requerimento subscrito por um décimo dos parlamentares e atribui ao Presidente da Assembléia, como ordenador dos trabalhos legislativos, a incumbência de publicar a relação dos projetos que se encontram nessa situação.

No procedimento legislativo abreviado, o prazo concedido pelo legislador regimental para que um décimo dos membros da Assembléia requeira, ou não, a deliberação final do Plenário, serve também para confirmar aprovação, ou rejeição ficta do projeto pelo Plenário. Vale dizer, a delegação de competência do Plenário à Comissão de mérito para que esta exerça, em nome daquele, a função deliberativa do Legislativo, pode ser suspensa, desde que haja, no prazo fixado pelo legislador regimental, o pedido de um décimo dos membros da Assembléia. Inexistente o requerimento, presume-se conclusiva a deliberação da Comissão de mérito e, pois, aprovado ou rejeitado o projeto, na forma do decidido pela Comissão. 


\subsection{Procedimento legislativo sumário}

O procedimento legislativo sumário aplica-se aos projetos de lei de iniciativa do Governador e, no Estado do Pará, também aos projetos de iniciativa do presidente do Tribunal de Justiça e da Mesa da Assembléia (art. 107), que contenham solicitação de urgência do autor. Essa urgência é conhecida como urgência constitucional, porque prevista em todas as Constituições Estaduais, que também prescrevem as linhas gerais desse procedimento legislativo. Nesses casos, estipula-se que a Assembléia Legislativa disporá, depois de solicitada a urgência, de quarenta e cinco dias para deliberar sobre o projeto. Se, nesse período não houver deliberação, o projeto será incluído em Ordem do Dia até ou para que se ultime sua votação, com sobrestamento da discussão e votação das demais matérias. No Rio Grande do Sul, se o Governador solicitar, para projeto de sua iniciativa, apreciação em regime de urgência, a Assembléia disporá de trinta dias (art. 62, § $1^{\circ}$, da Constituição Estadual). Se não houver deliberação sobre o projeto no prazo de trinta dias, será ele incluído na Ordem do Dia, sobrestando-se a deliberação de "qualquer outro assunto" até que se ultime a sua votação.

Como se vê, por este procedimento buscou-se abolir o decurso de prazo, expediente previsto no ordenamento constitucional imediatamente anterior, que presumia aprovado projeto de iniciativa do Executivo, não fosse ele deliberado no prazo constitucionalmente determinado. O constituinte cearense foi o único constituinte estadual de 1989, que ainda tentou manter o decurso de prazo, não para aprovação, mas para rejeição ficta de um projeto de lei. Determinou inclusão automática em Ordem do Dia de projeto de iniciativa do governador com solicitação de urgência e estipulou que, após quarenta e cinco dias do pedido de urgência e após mais dez sessões consecutivas de inclusão na Ordem do Dia do projeto, se, ainda assim, ele não tivesse sido deliberado, seria, então, considerado "definitivamente rejeitado" (art. 63, $\S 2^{\circ}$, da Constituição Estadual do Ceará). ${ }^{203}$

Subjacente nessa questão de aprovação ou rejeição por decurso de prazo, a antítese que acompanha o tema: celeridade / morosidade das decisões legislativas.

\footnotetext{
203 ADI 143-4. Rel. Min. Celso de Mello. Decisão monocrática final: "Tendo em vista reiterada omissão do autor da presente ação direta, que se absteve - não obstante formalmente intimado - de subsidiar esta Corte com a prestação de informações relevantes ao prosseguimento da causa, julgo-a extinta, com a conseqüente cassação das medidas cautelares anteriormente deferidas (fls. 238/256 e fls. 257/264)."
} 
Sobre o expediente do decurso de prazo Andyara Klopstock Sproesser tece as seguintes ponderações:

"Apesar da oposição que possa sofrer, - e sofre, especialmente nas Casas Legislativas, o que é compreensível, - o certo é que a aprovação por decurso de prazo não é incompatível com a liberdade parlamentar.

Ficou-lhe essa pecha - de incompatibilidade - por haver sido instituída no País pelo regime militar instaurado em 1964. Abstração feita, no entanto, da sua origem, não há por que negar-lhe o mérito de responder à moderna demanda social por maior presteza no processo legislativo.

Convenha-se, ademais, em que a aprovação por decurso de prazo não atinge a liberdade parlamentar, na medida em que sua existência não significa negar-se ao Legislativo - processualmente falando - a possibilidade de votar $\boldsymbol{n} \tilde{a} \boldsymbol{o}$ nas deliberações sobre quaisquer projetos.

De sorte que, se instituída em texto constitucional democrático, a aprovação por decurso de prazo representaria, sem dúvida, um movimento claro no sentido de satisfazer às instâncias da sociedade pela aprovação oportuna, breve, sem delongas, das proposições legislativas de interesse público, geral, coletivo.

Ademais disso, contribuiria para evitar o desgaste da imagem do Legislativo, que infelizmente só reconhece presteza no seu comportamento quando estão em jogo interesses seus, corporativos. (...)

Silenciando-se o Legislativo, muito embora pudesse e devesse manifestar-se no caso específico, nada mais justo, do ponto de vista coletivo ou social, do que se concluir que aprovou.

A vida do País reclama por celeridade. À sociedade aborrece a procrastinação. De sorte que o Legislativo faria bem, se impusesse a si mesmo essa regra.

É preciso encontrar novos caminhos, dar um passo adiante em matéria de regimes de tramitação, que, como técnica, tiveram sua serventia a um tempo em que a vida social não reclamava, como agora, medidas de urgência, para atender às instâncias do presente." 204

No procedimento legislativo sumário aboliu-se, como se observou, o decurso de prazo e criou-se o sobrestamento de proposições. Mas, no exercício de sua autonomia, os constituintes de São Paulo (art. 26) e Roraima (art. 42, § $1^{\circ}$ ) não o adotaram. ${ }^{205}$ Certamente fundamentados em forte convicção de que não é mais de

\footnotetext{
${ }^{204}$ Direito Parlamentar - processo legislativo. 2. ed., São Paulo: Alesp/SGP, 2004, p. 80-81.

205 Registre-se que, em São Paulo, a EC n. 21, de 14-02-06, adotou o sobrestamento e, antes de transcorridos três meses, a EC n. 22, de 25-05-06 o aboliu. Sua adoção deu-se no bojo de alterações de inúmeros dispositivos constitucionais e, quando se foi colocar em prática o expediente do sobrestamento, simplesmente houve exigência para sua supressão pela minoria parlamentar, que não sabia ao certo o que tinha aprovado na EC n. 21.
} 
observância compulsória para os Estados-membros a irrestrita adoção do processo legislativo federal. O sobrestamento de proposições - preterição do andamento das demais proposições que figuram na Ordem do Dia em benefício somente dos projetos de autoria do Executivo, com solicitação de urgência constitucional - é regra que informa um procedimento legislativo, o sumário, não se constituindo em princípio constitucional. De modo que, ao não adotarem o sobrestamento de proposições, os constituintes paulistas e roraimenses admitiram figurar na Ordem do Dia de suas Assembléias Legislativas, juntos, sem primazia, tanto os projetos de lei de iniciativa governamental, com solicitação de urgência prevista constitucionalmente, como também os demais projetos de autoria outra, que não a governamental, e que igualmente tramitam em regime de urgência, mas a urgência já prevista por norma regimental e decorrente de aprovação do Plenário da Assembléia ou a resultante de enquadramento automático de matéria nesse regime de tramitação pelo próprio legislador regimental. O Regimento Interno da Assembléia Legislativa do Amazonas, ao disciplinar a tramitação de urgência, incluiu também a solicitação do Governador à deliberação do Plenário (art. 171, I). No entanto, quando não há expressa norma regimental assim dispondo, recorrente a indagação nas Casas Legislativas estaduais sobre o alcance da solicitação de urgência, feita pelos Governadores, a projetos de lei de sua autoria.

Por se tratar de solicitação, não caberia, ao Plenário da Assembléia Legislativa aprová-la ou rejeitá-la, em legítima avaliação sobre o preenchimento de requisitos da urgência, como se dá no âmbito da Assembléia Legislativa amazonense, por exemplo?

As dúvidas sobre a interpretação do Regimento Interno, na sua prática ou relacionada com a Constituição, como a que se põe, constituem-se Questões de Ordem que, suscitadas pelos parlamentares, são resolvidas pelo Presidente da Casa Legislativa. Ou então, o Presidente pode delegar ao Plenário a decisão da Questão. Na ausência de norma regimental específica remetendo ao Plenário a deliberação da urgência pelo Governador requerida, o entendimento de presidências das Assembléias Legislativas ${ }^{206}$ acompanha, in casu, a disciplina regimental sobre a mesma matéria dada pela Câmara

${ }^{206}$ Questão de Ordem n. 1, levantada em 17-10-1989, na Assembléia Legislativa de São Paulo, pelos Dep. Vanderlei Macris, Luiz Máximo, José Mentor e Dep. Clara Ant, contraditada pelo Dep. Aloysio Nunes Ferreira; in Diário Oficial do Estado de São Paulo, Poder Legislativo, edição de 17-11-89, p. 54-55. 
dos Deputados: a solicitação do regime de urgência poderá ser feita pelo Presidente da República (art. 64, $\S 1^{\circ}$, da CF) depois da remessa do projeto, em qualquer fase de seu andamento, aplicando-se a partir daí o regime de urgência (art.204, $\S 1^{\circ}$ ), independentemente de deliberação do Plenário. Tratar-se-ia de faculdade conferida ao Chefe do Executivo que, ao ser exercida, conteria direito potestativo a sua implementação, independentemente de aprovação pelo Plenário da Assembléia, por presunção de que a urgência solicitada reveste-se sempre do requisito da correta discricionariedade do Chefe do Executivo ao requerê-la.

Resta a observação de que algumas Constituições Estaduais restringiram o alcance da discricionariedade dos Governadores na solicitação de urgência, não admitindo sua aplicação para projetos de codificação (Alagoas, art. 88; Amapá, art. 106, § 2 $2^{\text {; }}$ Bahia, art. 79, § 2o; Goiás, art. 22, § 2o; Mato Grosso do Sul, art. 69, § $3^{\text {o }}$; Pernambuco, art. 21, $\S 2^{\circ}$; Rio de Janeiro, art. 114, $\S 2^{\circ}$; Rio Grande do Norte, art. 47, $\S 3^{\circ}$; Rondônia, art. 41, § $2^{\circ}$; Roraima, art. 42, $\S 2^{\circ}$; e Sergipe, art. $63, \S 2^{\circ}$ ); projeto de lei complementar (Amazonas, art. 35, § 2º ; Espírito Santo, art. 65, § 2º Mato Grosso, art. $41, \S 2^{\circ}$; e Paraíba, art. $64, \S 4^{\circ}$ ); para projeto de lei orgânica, código e estatuto (Acre, art. 54, § 3º Pará, art. 107, § 2º e Paraná, art. 66, § 3); orçamento (Bahia, art. $79, \S 2^{\circ}$ ); e para projeto "que dependa de quorum especial para aprovação; de lei orgânica, estatutária ou equivalente a código; e a projeto relativo a plano plurianual, diretrizes orçamentárias, orçamento anual ou crédito adicional” (art. 69, $\S 2^{\circ}$, da Constituição de Minas Gerais). Como se vê, o constituinte mineiro apurou a limitação dos projetos que podem ser submetidos ao procedimento legislativo sumário; cerceando as opções de discricionariedade do Executivo para solicitação de urgência, fortaleceu o alvedrio do Legislativo para disciplinar, mediante norma regimental, o trâmite de matérias desse escol.

Os Regimentos Internos das Assembléias Legislativas não adotam o procedimento legislativo sumaríssimo, tal como previsto pelo Regimento da Câmara dos Deputados (art. 155) e do Senado (art. 336, alíneas "a" e "b"). Nesse procedimento pode ser incluído automaticamente na Ordem do Dia, para discussão e votação imediata, ainda que iniciada a sessão em que for apresentada, proposição que verse sobre matéria de relevante e inadiável interesse nacional, a requerimento da maioria absoluta da composição da Câmara, ou de Líderes que representem esse número, desde que aprovado pela maioria absoluta dos Deputados. É a urgência urgentíssima, como 
ficou conhecida essa tramitação. Não obstante servir para imediata discussão e votação de matéria que envolva segurança nacional e calamidade pública, é utilizada para inclusão na Ordem do Dia, de sessão já iniciada, de qualquer proposição que merecer essa avaliação de, pelo menos, maioria absoluta dos parlamentares ou de Líderes que representem essa grandeza.

\subsection{Especial}

O procedimento legislativo especial é o empregado, com ritos distintos, para que a Assembléia Legislativa efetive o poder constituinte decorrente do qual está investida (emendas constitucionais); a função legislativa também (divisão territorial administrativa do Estado - criação, incorporação, fusão e desmembramento de Municípios; plano plurianual, diretrizes orçamentárias e orçamento; medidas provisórias); a função de físcalização e controle do Executivo (contas do Governador; sustação de atos normativos do Poder Executivo, que exorbitem do poder regulamentar ou dos limites de delegação legislativa; sustação de contrato julgado irregular pelo Tribunal de Contas); função julgadora (impeachment do Governador; destituição do Procurador-Geral de Justiça); competência autonormativa (Regimento Interno).

O procedimento legislativo especial envolve, na verdade, outros tantos procedimentos, diferentes em relação aos procedimentos padrão, abreviado e sumário. O procedimento especial não se confunde com a elaboração de cada uma das demais espécies legislativas, excetuada a proposta de emenda constitucional. É que, mesmo a elaboração de lei, que deveria seguir o procedimento legislativo padrão, pode não observá-lo, mas aí em razão da matéria disciplinada, que acabou por merecer normas procedimentais especiais. Veja-se, e.g., a criação de Municípios, que se efetiva mediante lei ordinária, mas que ostenta nos Regimentos Internos das Assembléias Legislativas procedimento diferente do padrão. Observe-se, da mesma forma, especial disciplina procedimental em relação aos projetos de lei ordinária para elaboração do plano plurianual, diretrizes orçamentárias e orçamento. De modo que, quando há referência a procedimento legislativo especial não é necessariamente para se fazer a correspondência com as demais espécies legislativas; pode até haver coincidência, como é o caso do procedimento legislativo especial para proposta de emenda à constituição, mas não há necessariamente correspondência. Frise-se. O procedimento legislativo especial rege-se pelas peculiaridades procedimentais previstas em função da matéria disciplinada. E como são várias as matérias que mereceram do legislador 
constituinte e do regimental tratamento especial, vários também são os procedimentos legislativos especiais previstos. 


\section{CAP. 7 FASES PROCEDIMENTAIS}

No processo legislativo previsto constitucionalmente constata-se a fase da iniciativa, apresentação da proposição; a constitutiva, que compreende a deliberação no âmbito do Legislativo e a deliberação no âmbito do Executivo, sanção ou veto; e a fase complementar, onde se insere a promulgação e igualmente a publicação. Neste capítulo 7 cuidar-se-á da apresentação até a deliberação do Legislativo.

\subsection{Apresentação da proposição - Técnica legislativa - Legística}

A Assembléia Legislativa de Minas Gerais, em setembro de 2007, organizou o "Congresso Internacional de Legística - Qualidade da Lei e Desenvolvimento". Gabriela Horta Barbosa Mourão e Raquel Mansur de Godoy, em publicação temática, decorrente do aludido congresso, salientam que "a Legística é a área do conhecimento que se ocupa de como fazer as leis, de forma metódica e sistemática, tendo por objetivo aprimorar a qualidade desses atos normativos. A qualidade da lei é definida em função de diversos fatores, sendo os mais relevantes a capacidade de produzir os efeitos pretendidos, a harmonização com o ordenamento vigente, o equilíbrio entre custos e benefícios, a acessibilidade, a aplicabilidade e a efetividade da norma". ${ }^{207}$

Em observância às finalidades da legística, pois, as proposições apresentadas à tramitação legislativa devem conter, independentemente do conteúdo, uma técnica de elaboração. Daí se dizer que legislar bem implica, necessariamente, utilizar-se de uma boa técnica legislativa, com atenção à devida forma, à clareza, à sistematização e integração do conteúdo jurídico novo ao conteúdo passado e ao presente. Essas últimas preocupações apontam para a necessidade de se efetivar processo de consolidação da legislação, no âmbito de cada ente federativo, e só identificado pelo constituinte federal de 1988 (parágrafo único do art. 59). ${ }^{208}$ Com efeito, no sistema federativo são várias as fontes de emanação de direito novo e conviria, para a sedimentação da segurança jurídica, que os destinatários das normas jurídicas federais, estaduais, distrital e municipais pudessem ter certeza da respectiva legislação vigente, daí tornar-se imperioso o esforço para se efetivar consolidação das leis federais, estaduais, distrital e municipais, muitas vezes dispostas em verdadeiros cipoais legais, aludindo-se até à

\footnotetext{
${ }^{207}$ Elaboração legislativa - Congresso - Minas Gerais. Belo Horizonte: Assembléia Legislativa de Minas Gerais, 2007, p. 3.

${ }^{208}$ CALIMAN, Auro Augusto; JEHA, Pedro Rubez. Ordenamento jurídico brasileiro: a consolidação das leis como método reorganizador e simplificador da legislação. In: Revista Jurídica 9 de Julho. São Paulo: Alesp, n. 3, 2004, p.163-180.
} 
figura de uma babel jurídica, decorrente da propalada inflação legislativa. ${ }^{209} \mathrm{Na}$ constatação de Manoel Gonçalves Ferreira Filho: “A multidão de leis afoga o jurista, esmaga o advogado, estonteia o cidadão, desnorteia o juiz. A fronteira entre o lícito e o ilícito fica incerta. A segurança das relações sociais, principal mérito do direito escrito, se evapora". ${ }^{210}$

Uma boa técnica legislativa repercute na efetividade da norma. Trata-se, como acentua Kildare Gonçalves Carvalho, de "engenharia social, arquitetura da lei e não de dogmática jurídica"; ainda com o autor, "o estudo da técnica legislativa poderá contribuir para que a concisão, a clareza, a simplicidade e a unidade de estilo prevaleçam sobre a prolixidade, a obscuridade, o pernosticismo e a falta de lógica, garantindo a certeza das relações jurídicas e a segurança social, fundamentos do próprio Estado Democrático de Direito". 211

Imbuídas dessa preocupação, Assembléias Legislativas como a de Minas Gerais e a de São Paulo, e. g., editaram, respectivamente, Manual de Redação Parlamentar $^{212}$ e Manual do Processo Legislativo ${ }^{213}$, buscando assentar referências teóricas e práticas para assessoria parlamentar, notadamente, no tocante à elaboração de proposições legislativas. Justamente porque, como salientam Gabriela Horta Barbosa Mourão e Raquel Mansur de Godoy, “os problemas que possam atingir as leis, tais como contradições, lacunas, falta de clareza, inadequação de meios para se atingirem os objetivos propostos e falta de uma estratégia eficiente de comunicação, podem gerar dificuldades de conhecimento e interpretação das normas que entram em vigor e trazer sérios prejuízos ao cidadão, ao Estado e aos negócios, além de sobrecarregar o Judiciário com questões que poderiam ser resolvidas com uma legislação mais bem elaborada". 214

No âmbito de cada ente federativo regional buscou-se dar efetividade à formulação de normas técnicas de elaboração legislativa, nos moldes das Leis Complementares federais n. 95/98 e 107/2001, e do Decreto n. 4.176/02, que as regulamentou. Em alguns Estados-membros já houve edição de leis complementares

\footnotetext{
209 RIZEK FILHO, Rubens Naman. Formas de aceleração do processo legislativo. Fadusp (dissertação de Mestrado), 2001. p. 3-8.

${ }^{210}$ Processo legislativo. 6. ed., São Paulo: Saraiva, 2007, p. 13.

${ }^{211}$ Técnica legislativa. 4. ed. Belo Horizonte: Del Rey, 2007, p. 3.

${ }^{212}$ Belo Horizonte: ALMG, 2005.

${ }^{213}$ CALIMAN, Auro Augusto. Supervisão geral. 2. ed. São Paulo: ALESP, 2004.

${ }^{214}$ Qualidade da lei e desenvolvimento. Belo Horizonte: ALMG, 2007, p. 33.
} 
dispondo sobre elaboração, redação, alteração e consolidação das leis, e estabelecendo normas para consolidação de atos normativos que mencionam. ${ }^{215}$ Parte do conteúdo dessas leis, o que se refere à elaboração e redação de proposições legislativas, há muito vem contemplado nos Regimentos Internos das Casas Legislativas, os quais, também, dispõem de norma de não admissibilidade de proposições quando não devidamente redigidas. Registre-se, outrossim, que a preocupação de uniformizar a técnica legislativa, há muito, já se fazia presente. ${ }^{216}$

\subsection{Controle preventivo da constitucionalidade}

Inserido como controle preventivo de constitucionalidade relativamente ao ingresso no ordenamento jurídico de lei ou de ato normativo, no sistema brasileiro este controle se dá no âmbito das comissões de constituição e justiça das Casas Legislativas e por intermédio do veto jurídico. Como salienta Alexandre de Moraes, “o controle preventivo de constitucionalidade é realizado sempre dentro do processo legislativo, em uma das hipóteses pelo Poder Legislativo (comissões de constituição e justiça) e em outra pelo Poder Executivo (veto jurídico)". ${ }^{217}$

Os Regimentos Internos das Assembléias Legislativas prevêem também outra oportunidade, anterior à da comissão de constituição e justiça, para se proceder igualmente ao controle preventivo de constitucionalidade. Trata-se do juízo prévio de admissibilidade das proposições. Provém de competência outorgada ao Presidente ou à Mesa Diretora da Assembléia para admitir, ou não, proposições legislativas, na forma que os respectivos Regimentos Internos especificam.

Embora todos prevejam esse controle, os Regimentos diferenciam-se quanto à inserção de matérias diversas no rol das proposições que não devam ser admitidas à tramitação. Como lugar comum, os Regimentos dispõem que o Presidente ou a Mesa Diretora deixará de admitir proposições: (a) manifestamente inconstitucionais; (b) que

\footnotetext{
215 Amapá (Lei complementar n. 24/2004), Mato Grosso do Sul (Lei complementar n. 105/2003), Minas Gerais (Lei complementar n. 82/2004), Pará (Lei complementar n. 65/2008), Rondônia (Lei complementar n. 236/2000), Santa Catarina (Lei complementar n. 208/2001), Tocantins (Lei complementar n. 28/2001).

${ }^{216}$ Informa Andyara Klopstock Sproesser: "Mas, antes dessa lei federal [95/98], já havia no Estado de São Paulo, de modo pioneiro ao que se pode saber, legislação nesse mesmo sentido, como resultado de trabalho conjunto das assessorias do Executivo e da Assembléia Legislativa, respectivamente Assessoria Técnico-Legislativa-ATL e Assessoria Técnica da Mesa-ATM. Trata-se do Decreto-Lei Complementar n. 1, de 11 de agosto de 1969, substituído pela Lei Complementar n. 60, de 10 de julho de 1972, finalmente substituída pela Lei Complementar n. 863, de 29 de dezembro de 1999, atualmente em vigor." Processo Legislativo. 2. ed., São Paulo: ALESP/SGP, 2004, p. 70.

${ }^{217}$ Direito Constitucional. 21. ed., São Paulo: Atlas, 2007, 682.
} 
disponham sobre assunto alheio à competência da Assembléia Legislativa; (c) que deleguem a outro Poder atribuições privativas do Legislativo.

O Regimento da Assembléia de Mato Grosso do Sul adverte que não será recebido projeto relativo a criação de Município ou a alterações territoriais de Municípios, se estiver desacompanhado da documentação exigida pela legislação em vigor (art. 375, $\S 3^{\circ}$ ). O Regimento Interno da Assembléia Legislativa do Rio Grande do Sul acrescenta, ainda, àquele rol comum, que o Presidente devolverá ao autor, proposição que proponha a criação ou alteração de região metropolitana, aglomeração urbana, microrregião ou rede de municípios sem se fazer acompanhar de documentos comprobatórios do atendimento das exigências legais, fornecidos por órgão oficial. E estabelece também que não se admitirá proposição que seja meramente autorizativa, nos casos em que não seja necessária, por força constitucional ou de lei, autorização da Assembléia Legislativa (art. 166, VII e VIII).

A lei autorizativa, quando proveniente de projeto de iniciativa parlamentar, mais não faz que autorizar o Executivo a exercer competência que já lhe é própria, prescindindo-se, pois, da autorização legal que, neste caso, confunde-se com outra proposição legislativa, a Indicação; nesta sim, o parlamentar pode sugerir a outro Poder adoção de alguma medida de interesse público, seja um ato de gestão, um ato administrativo, ou até "o envio de projeto sobre matéria de sua iniciativa exclusiva, sugestão que o destinatário acolhe ou não, segundo o seu alvedrio". ${ }^{218}$ E, mesmo quando a lei autorizativa for de iniciativa do Poder Executivo, que a solicitara ao Legislativo para exercer competência própria, ainda assim, o juízo da conveniência e da oportunidade para a prática do ato jurídico autorizado ainda remanesce com o Chefe do Poder Executivo, que poderá, ou não, realizá-lo. ${ }^{219}$

Como do juízo de admissibilidade das proposições, exercido por quem deve fiscalizar a ordem do processo legislativo, cabe recurso à Comissão de Constituição e Justiça, não deixa de ser este órgão técnico o encarregado de efetuar o controle preventivo da constitucionalidade.

Evidente que, sob a perspectiva do controle preventivo de constitucionalidade, há, no processo legislativo, outros controles internos. Assim,

\footnotetext{
${ }^{218}$ SILVA, José Afonso. Processo constitucional de formação das leis. 2. ed. São Paulo: Malheiros, 2006. p. 333.

${ }^{219}$ Nesse sentido: STF, MS 21.769-DF, rel. Min. Celso de Mello.
} 
desde a apresentação da propositura até a fase de apreciação do veto jurídico, ocorrem variados controles internos. Exemplifica-se. 1) Por vício de forma (a matéria a ser disciplinada exige lei complementar e o autor apresenta projeto de lei ordinária) ou de conteúdo (a matéria não é de competência dos Estados-membros), a proposição pode não ser admitida pelo Presidente ou pela Mesa Diretora. 2) Quando em exame na Comissão de Constituição e Justiça, que pode até mesmo rejeitar a matéria. 3) A não inclusão da proposição na Ordem do Dia é também um outro modo de controle interno exercido pelo Presidente da Casa Legislativa, que pode exercitá-lo, inclusive, porque motivado pela convicção de tratar-se de matéria inconstitucional. 4) Por ocasião da discussão, os oradores que se inscrevem motivados em debater a matéria por entendê-la inconstitucional, procrastinando, com os debates, uma imediata decisão; ou a tentativa de, com a discussão, convencer os demais pares acerca de sua conviç̧ão sobre a inconstitucionalidade da matéria; ainda nessa fase da discussão, quando se requer o adiamento da discussão, por franca motivação obstrucionista, justamente porque haveria fundadas razões de se tratar de matéria, total ou parcialmente, inconstitucional. 5) Na fase deliberativa propriamente dita, para se evitar a conclusão da votação, requerse verificação de votação ou votação nominal na expectativa de que não haja quorum para aprovação da matéria; destaques de dispositivos tidos como inconstitucionais, como forma de procrastinar final deliberação.

A não ser esse controle (interno) preventivo da constitucionalidade de proposições legislativas, o Supremo Tribunal Federal deixou assente que, em homenagem ao princípio da separação de poderes, inexiste no sistema jurídico brasileiro a possibilidade de fiscalização abstrata preventiva da constitucionalidade de proposições legislativas, inclusive as estaduais, pelo Poder Judiciário; exceto concernente a proposta de emenda à Constituição tendente a abolir o cerne fixo da Constituição (art. 60, $\S 4^{\circ}$ ), somente neste caso haveria legitimidade conferida a parlamentar participante do processo legislativo para pleitear no Judiciário o controle normativo abstrato do processo legislativo de proposta de emenda que fosse tendente a abolir as cláusulas pétreas da Constituição. ${ }^{220}$ Mas, nada impede, também, que parlamentar, no exercício do mandato representativo, impetre mandado de segurança para coibir atos praticados no processo de formação de lei ou de emenda constitucional

\footnotetext{
${ }^{220}$ STF - pleno - ADI 466/DF. Rel. Min. Celso de Mello. Julgamento: 03/04/1991.

STF - pleno - MS 24.138/DF. Rel. Min. Gilmar Mendes. Julgamento: 28/11/2002.

STF - pleno - MS 20.257/DF. Rel. Min. Décio Miranda.
} 
incompatíveis com expressas disposições constitucionais ou regimentais que disciplinam o próprio processo legislativo. ${ }^{221}$

No rol das matérias sujeitas ao controle preventivo de constitucionalidade, as Assembléias Legislativas devem inserir em seus Regimentos Internos, ainda, o conteúdo da Súmula vinculante n. 2, em vigor desde 06 de junho de 2007. O Supremo Tribunal Federal antecipadamente indicou às Assembléias Legislativas que "é inconstitucional lei ou ato normativo estadual ou distrital que disponha sobre sistemas de consórcios e sorteios, inclusive bingos e loterias". De acordo com o STF, compete à União legislar privativamente sobre essa matéria.

\subsection{Análise e deliberação nas Comissões}

A Constituição de 1988 estabelece como reserva de Regimento Interno as atribuições das Comissões parlamentares, no que foi acompanhada por todas as Constituições Estaduais. Constituem atribuições das comissões permanentes, dentre as quais, ex vi de norma constitucional, as seguintes: a) discutir e votar projeto de lei que dispensar, na forma do regimento, a competência do Plenário, salvo se houver recurso de um décimo dos membros da Casa; b) realizar audiências públicas com entidades da sociedade civil; c) convocar Secretários de Estado para prestar informações sobre assuntos inerentes a suas atribuições; d) receber petições, reclamações, representações ou queixas de qualquer pessoa contra atos ou omissões das autoridades ou entidades públicas; e) solicitar depoimento de qualquer autoridade ou cidadão; f) apreciar programas de obras, planos de desenvolvimento e sobre eles emitir parecer. O rol de competências das comissões que os Regimentos Internos devem observar ao fixar-lhes as atribuições é considerável, quase resvalando em oportuno comentário feito por Manoel Gonçalves Ferreira Filho à Constituição Federal anterior, no qual indicara o surgimento de um "direito constitucional regimental",222, tantas as determinações impostas ao legislador regimental pelo constituinte.

Não se afigura despropositado o registro, nessa quadra, de que a Constituição italiana (art. 72) inspirou a disciplina do artigo 58, § $2^{\circ}$, I, da Constituição brasileira de 1988, e este, os dispositivos das Constituições Estaduais, delineando o sistema de comissões nas Casas Legislativas da Federação brasileira, onde se confere às

${ }^{221}$ STF - pleno - MS-AgR 24.667/DF. Rel. Min. Carlos Velloso. Julgamento: 04/12/2003.
${ }^{222}$ Comentários à Constituição Brasileira, 5. ed., p. 193. 
comissões permanentes a competência para discutir e votar projetos de lei, na forma definida pelo Regimento Interno da respectiva Casa Legislativa e onde se concede às comissões técnicas permanentes a atribuição de exarar pareceres técnicos e de mérito sobre proposições.

Por mandamento constitucional, pois, às Comissões permanentes atribui-se, na forma do que dispuser o Regimento Interno, competência para, em sede deliberante, discutir e votar projetos de lei. Discutem e votam conclusivamente projetos de lei, jamais, e.g., proposta de emenda constitucional, veto ou projeto de lei complementar já assinalados constitucionalmente com a reserva de Plenário, insuscetíveis, por conseguinte, de deliberação por qualquer outro quorum, senão aquele qualificado por maioria absoluta ou por 3/5 dos membros da Assembléia Legislativa.

Em havendo e na forma em que houver a previsão regimental, comissões técnicas permanentes podem substituir o Plenário do Poder Legislativo ${ }^{223}$, ou exercer delegação ${ }^{224}$ do exercício da função legislativa plena, mediante deliberação conclusiva, ou terminativa, sobre determinados projetos de lei.

$\mathrm{Na}$ disciplina das matérias sobre quais Comissões têm competência para deliberar conclusivamente, os Regimentos Internos das Assembléias Legislativas que normatizaram a matéria procuraram ser parcimoniosos, não se outorgando às Comissões todo e qualquer assunto. O Regimento Interno da Assembléia Legislativa de São Paulo dispõe, em numerus clausus, sobre os projetos de lei que podem ser objeto de discussão e votação conclusiva por uma Comissão de mérito; são os que disponham sobre declaração de utilidade pública de associações civis; denominação de estabelecimentos ou próprios públicos; instituição de data comemorativa, ou oficialização de eventos festivos, assim como sua inclusão no calendário turístico do Estado (art. 33, II). Já o Regimento da Assembléia Legislativa do Rio Grande do Norte não enumera taxativamente as matérias sujeitas à decisão terminativa das Comissões permanentes, preferindo indicar que projeto de lei complementar, projeto de lei de iniciativa popular, projeto de lei em regime de urgência não se submetem a esse procedimento legislativo abreviado. Adverte, ainda, que quando houver manifestações divergentes das Comissões sobre a mesma proposição, sempre ao Plenário caberá deliberar (art. 124, II). Nesse sentido também, o Regimento da Assembléia Legislativa

\footnotetext{
${ }^{223}$ SILVA, José Afonso da. Processo constitucional de formação das leis. 2. ed., p.106.

${ }^{224}$ FERREIRA FILHO, Manoel Gonçalves. Do processo legislativo. 3. ed., p. 135.
} 
do Rio Grande do Sul, que concede às comissões técnicas permanentes, na respectiva área de atuação, competência para discutir e votar projetos de lei e decretos legislativos, excetos os de leis orçamentárias, de iniciativa popular, de lei complementar, de código, de iniciativa de Comissão, em regime de urgência ou com parecer contrário da Comissão de Constituição e Justiça (art. 57, VI).

A decisão de mérito da Comissão competente, aprovando ou rejeitando determinada proposição, somente será final se não houver requerimento de um décimo dos membros da Assembléia para que o Plenário profira a decisão definitiva. Caso haja recurso de um décimo dos membros da Casa Legislativa, competirá ao Plenário a deliberação final.

O legislador regimental das Assembléias do Acre, Pará, Pernambuco, Sergipe e Tocantins ainda não dispuseram sobre essa competência deliberativa das suas comissões permanentes, mas já prevista nas respectivas Constituições Estaduais.

Contudo, no âmbito das Comissões, as proposições, salvo exceções constitucionais (veto e urgência constitucional com prazo para inclusão em Ordem do Dia), e em observância a preceitos regimentais, recebem, outrossim, pareceres opinativos acerca da sua legalidade, juridicidade e constitucionalidade; bem como os pareceres exarados também consideram o mérito das proposições. Efetiva-se, assim, o princípio do exame prévio do projeto por comissões parlamentares.

Constatam-se dois sistemas de exame prévio da constitucionalidade, juridicidade e legalidade de projetos pela comissão de Constituição e Justiça. O primeiro confere ao parecer votado pela comissão natureza meramente opinativa (Regimento paulista, e.g,). O segundo dá caráter conclusivo à votação de projeto rejeitado por maioria absoluta de votos na Comissão de Constituição e Justiça (art. 72, $\S 1^{\circ}$, do Regimento gaúcho; art. 143, caput, do Regimento catarinense, e.g.). Na primeira hipótese, remete-se automaticamente o projeto à discussão e votação prévia do Plenário para confirmar, ou não, a constitucionalidade do projeto; na segunda, deve haver, em prazo fixado, recurso ao Plenário subscrito por parlamentares interessados, caso não haja, ou, havendo, sendo o recurso improvido, será o projeto arquivado (art. $72, \S \S 2^{\circ}$ e $3^{\circ}$, do Regimento gaúcho; art. $143, \S \S 1^{\circ}$ a $3^{\circ}$ do Regimento catarinense).

Da mesma forma, há dois sistemas acerca da adequação orçamentária da proposição pela Comissão de Finanças e Orçamento; um com parecer tão-somente opinativo, e o outro terminativo. No primeiro caso, quando a proposição for incluída 
em Ordem do Dia, constará da sua ementa indicação ao Plenário de que o parecer da comissão, quanto ao mérito financeiro-orçamentário, é contrário. No segundo, haverá prazo para recurso ao Plenário, que poderá provê-lo; inexistindo recurso, restará arquivado o projeto em virtude de sua inadequação financeiro-orçamentária (art. 143, $\S \S 1^{\circ}$ a $3^{\circ}$ do Regimento catarinense).

\subsection{Ordem do Dia}

Como condição de admissibilidade do procedimento de formação das leis, além do funcionamento do Legislativo e da apresentação da propositura, figuram juntos a existência de quorum para deliberar e Ordem do Dia previamente anunciada.

Para que determinado projeto possa ser submetido a votos, impende que já se tenha constatado, na forma regimental, a existência no Plenário do quorum constitucional de deliberação. Sem que tenha havido esta constatação, há impedimento de se proceder à votação. É que, à evidência, para que o Presidente da sessão possa enunciar o comando de aprovação ou de rejeição de uma matéria posta a votos, imprescindível que o quorum deliberativo para ela exigido efetivamente exista. Cabe apontar, então, que, em ordem a se iniciar uma votação de matéria que não exija quorum qualificado, deve-se constatar, ao menos, a presença da maioria absoluta de parlamentares; e a presença de $3 / 5$ (três quintos) ou 2/3 (dois terços) para a votação das matérias que requeiram, respectivamente, esse montante de votos para aprovação. Adiante, apurar-se-á com rigor esta condição.

Já a Ordem do Dia diz respeito à parte da sessão, ou reunião plenária (como também é denominada a sessão, e.g., pelo Regimento Interno da Assembléia Legislativa de Minas Gerais, art. 22; Pará, art. 117) onde são discutidas e deliberadas as proposições adrede anunciadas, sejam elas de natureza legislativa, política, investigatória; enfim, é neste período da sessão, assim denominado de Ordem do Dia, que se delibera sobre as matérias de competência do Poder Legislativo. Por merecer primazia sobre as demais atividades, há preceito regimental determinando que nem mesmo as Comissões podem se reunir durante o período em que estiverem sendo desenvolvidas as atividades concernentes à Ordem do Dia no Plenário das Assembléias Legislativas.

Um dos grandes problemas das Assembléias Legislativas, do Congresso Nacional, das Câmaras Municipais e Casas Legislativas de outros países, inclusive, 
reside justamente na prévia organização de um calendário legislativo elaborado mediante planejamento, para que a sociedade, sabendo com antecedência sobre quando determinada matéria será discutida e votada, possa ela também se planejar, se organizar para acompanhar as sessões, se mobilizar para buscar influir na decisão que poderá ser tomada, ou se preparar para absorver as mudanças porventura advindas da decisão do Parlamento. Um calendário legislativo envolve, pois, a divulgação antecipada das proposições que figurarão na Ordem do Dia em datas já predeterminadas.

Mas, quais proposições? Quem pode escolhê-las? Quem pode, afinal, pautar os trabalhos legislativos?

O Presidente da Assembléia Legislativa, além de atuar como representante da Assembléia quando ela houver de se enunciar coletivamente, é o regulador dos seus trabalhos e da sua ordem, estabelecem expressamente os Regimentos Internos das Casas Legislativas estaduais. A ele compete anunciar a Ordem do Dia das sessões ordinárias e extraordinárias, facultando-se-lhe a consulta ao Colégio de Líderes para escolha das proposições (RIMG-art. 81, VII), ou devendo compartilhar com o Colégio de Líderes a incumbência da seleção das proposições relacionadas à Ordem do Dia das sessões ordinárias (XIII CRI-SP, art. 83, caput), ficando ao seu exclusivo alvedrio somente a seleção de matérias para compor a Ordem do Dia das sessões extraordinárias. Da mesma forma, os Líderes, em conjunto, mas sem a interferência do Presidente, podem escolher a matéria da Ordem do Dia de sessão extraordinária e convocá-la (XIII CRI-SP, art. 100, II). Esta última hipótese, quando implementada, denota evidente dissenso entre o órgão diretivo e as Lideranças partidárias e não deixa de ser anteparo a eventuais repentes autoritários do Presidente a impingir aos demais membros da Assembléia uma Ordem do Dia sabidamente controversa.

No procedimento legislativo gaúcho, preceito constitucional (art. 63) determina que, depois de transcorridos trinta dias do recebimento de qualquer proposição, o Presidente da Assembléia, a requerimento de qualquer parlamentar, ordenará seja ela incluída na Ordem do Dia. Até a entrada em vigor da Emenda Constitucional n. 39, de 12 de dezembro de 2003, a proposição requerida passava, então, a figurar na Ordem do Dia, "independentemente de parecer”. Somente a partir da vigência da EC n. 39 é que houve exigência de parecer exarado pela Comissão de Constituição e Justiça para que a proposição pudesse, a pedido de qualquer 
parlamentar, constar da Ordem do Dia até final deliberação e, somente por desistência de quem solicitara a inclusão, a proposição poderia dela ser retirada.

Nesse mesmo diapasão inclusivo, o constituinte baiano determinou: desde que devidamente instruída "nenhuma matéria sujeita a processo legislativo poderá, a contar de sua apresentação, ultrapassar sessenta dias para ser colocada em votação, sobrestando-se a apreciação das demais até que se atenda a esta exigência" (art. 73).

Esses comandos denotam a possibilidade de as proposições, após instruídas, não se tornarem nem objeto de deliberação do colegiado legislativo, o que afrontaria direito dos que deflagram o processo legislativo, mediante apresentação ao Parlamento de proposição apta à apreciação. Como acentua José Afonso da Silva, fundamentado em monografia de Enrico Spagna Musso, ${ }^{225}$ "nos Estados-membros, as respectivas Assembléias Legislativas são as destinatárias da iniciativa das leis estaduais", entendendo por "destinatários da iniciativa das leis os órgãos do Poder Legislativo a que o titular do poder de iniciativa se dirige no ato de exercê-lo" ${ }^{226}$, daí a necessidade de as Assembléias Legislativas formularem normas regimentais que tanto amparem os titulares da iniciativa quanto lhes garantam o direito de inclusão em Ordem do Dia das proposituras apresentadas e, obviamente, que isso venha a ocorrer, quando mais não seja, durante a legislatura, sob pena de, em observância ao princípio da unidade da legislatura, restarem, ao final, arquivadas as proposições.

A importância da formulação do conteúdo de Ordem do Dia fez com que se constitucionalizassem preceitos de mera autonormatividade, postos nos Regimentos Internos das Casas Legislativas. Em geral, os comandos constitucionais protegem proposições de iniciativa do Executivo, determinando que sejam incluídas automaticamente na Ordem do Dia, após certo prazo de tramitação, em regra após quarenta e cinco dias do início da tramitação. E, quando incluídas, exceto em São Paulo e Roraima, as proposições de iniciativa do Executivo com solicitação de urgência do próprio Governador sobrestam as demais. ${ }^{227} \mathrm{O}$ mesmo ocorre com os projetos de lei vetados. Da mesma forma, transcorridos trinta dias do recebimento do veto, os projetos

${ }^{225}$ L'iniziativa nella formazione delle leggi italiane. Napoli: Casa Editrice Dott. Eugenio Jovene, 1958, p. 100-121.

${ }^{226}$ Processo constitucional de formação das leis. 2. ed., São Paulo: Malheiros, 2006, p. 163, e nota 1 da página 134.

${ }^{227}$ No Pará, além dos projetos de lei de iniciativa do Governador, também os de iniciativa do Tribunal de Justiça e os de iniciativa do Presidente da Assembléia Legislativa podem ser objeto de solicitação de urgência constitucional (art. 107) e, decorrido o prazo de 45 dias sem deliberação, são incluídos em Ordem do Dia até final deliberação, com sobrestamento das demais proposições. 
são incluídos em Ordem do Dia até final deliberação, sobrestando-se as demais proposições; exceto, como já assinalado, em São Paulo e Roraima, cujos textos constitucionais não adotaram o sobrestamento.

Nas Assembléias Legislativas, cujas Constituições Estaduais prevêem a medida provisória como espécie legislativa ( Acre, art. 52; Maranhão, art. 40; Paraíba, art. 61; Piauí, art. 74; Santa Catarina, art. 48; e Tocantins, art. 25), há determinação para sobrestamento de "todas as demais deliberações legislativas", na forma do comando utilizado pela Constituição Federal em seu artigo 62, § 6 ${ }^{\circ}$. Com efeito, a expressão "deliberações legislativas" suscitou dúvidas no âmbito da Câmara dos Deputados, ensejando formulação de Questão de Ordem ${ }^{228}$. Indagou-se:

“O SR. JOSÉ CARlos AlEluia (PFL-BA. Como Líder. Sem revisão do orador.) - Sr. Presidente, quero apresentar uma questão de ordem para que possamos avançar na nossa pauta. Não o fiz porque estava no Supremo Tribunal Federal acompanhando a decisão dos Ministros. A questão de ordem é extensa e será entregue à Mesa. Mas quero explicar do que se trata. A Constituição Federal, no seu art. 62 , $\S 6^{\circ}$ e a Emenda n. 32, de 2001, dispõem sobre as medidas provisórias e estabelecem que, decorrido o prazo de deliberação, não tendo sido votada a medida provisória, as deliberações legislativas da Casa têm a sua tramitação sobrestada. Ou seja, a pauta fica suspensa em razão da não votação da medida provisória. A tese que trago aqui, fundamentada pela consultoria jurídica do meu partido e da Liderança da Minoria, levanta a idéia de que não se pode estender a deliberações legislativas decisões como a votação do processo de cassação do mandato do Deputado André Luiz. Esse processo, assim como a escolha dos 2 representantes do Poder Legislativo para o Tribunal de Contas da União, no nosso entendimento e no de alguns juristas, não se trata de decisão legislativa."

\section{DECISÃO DA PRESIDÊNCIA:}

“O nobre Deputado José Carlos Aleluia, na Sessão Plenária de 20 de abril de 2005, levantou a Questão de Ordem n. 536/2005, por meio da qual indaga sobre o sentido do disposto no $\S 6^{\circ}$ do art. 62 da Constituição da República, que determina o sobrestamento das deliberações legislativas da Casa em que estiver tramitando a Medida Provisória não apreciada pelo Congresso Nacional no prazo de quarenta e cinco dias, contados da publicação. Manifesta o entendimento de que o referido sobrestamento não alcança deliberações não legislativas, tais como eleição da Mesa Diretora da Câmara dos Deputados, escolha de membros do Tribunal de Contas da União e decisão acerca da perda do mandato de integrante desta Casa. Inquire,

\footnotetext{
${ }^{228}$ Questão de Ordem n. 536, de 20-04-2005. Pesquisa em www.camara.gov.br (v. plenário).
} 
ao final, se o sobrestamento das deliberações legislativas desta Câmara atinge os itens 12 e 14 da Ordem do Dia, quais sejam a REP n. 25/2004, da Mesa, "contra o Deputado André Luiz, como incurso na previsão do art. 55, II e $\S 1^{\circ}$, da Constituição Federal, combinado com o art. $4^{\circ}$, I, do Código de Ética e Decoro Parlamentar", e o PDC n. 1.353/2004, do Senado, que "escolhe o Senhor Luiz Otavio Oliveira Campos para o cargo de Ministro do Tribunal de Contas da União, nos termos do art. $73, \S 2^{\circ}$, II, da Constituição Federal". $\quad$ É o relatório. Decido.

Com efeito, na dicção do $\S 6^{\circ}$ do art. 62 da Constituição da República, litteris, "Se a medida provisória não for apreciada em até quarenta e cinco dias contados de sua publicação, entrará em regime de urgência, subseqüentemente, em cada uma das Casas do Congresso Nacional, ficando sobrestadas, até que se ultime a votação, todas as demais deliberações legislativas da Casa em que estiver tramitando". É dizer, somente as deliberações legislativas são alcançadas pelo sobrestamento resultante da não-apreciação das Medidas Provisórias no prazo constitucional. Afigura-me, pois, de fundamental importância ao deslinde da Questão de Ordem suscitada pelo insigne Deputado José Carlos Aleluia a definição do sentido e alcance da expressão deliberações legislativas. Preliminarmente, cumpre-me observar a natureza restritiva da norma inscrita na parte final do dispositivo constitucional acima transcrito. Sendo restritiva a norma, haverá de ser ela interpretada e aplicada restritivamente. Feita essa ponderação vestibular, procedo ao delineamento do significado e abrangência da norma em sua acepção estrita. Deliberações legislativas são as decisões de que decorrem os provimentos normativos, independentemente do órgão que tenha competência para proferi-las e do instrumento por meio do qual essa competência é exercida. Explico. Deliberações legislativas são decisões de que são produtos normas gerais, abstratas, impessoais, coercitivas e inovadoras do ordenamento jurídico. Tais decisões são prolatadas predominantemente pelo Poder Legislativo. O Executivo e o Judiciário, entretanto, podem exercer funções legiferantes nos casos expressamente previstos na Constituição. Tituladas pelo Poder Legislativo, essas funções são exercidas por meio de Leis, em se tratando de matéria de competência conjunta do Congresso Nacional e do Presidente da República; de Decretos Legislativos, em se cuidando de matéria de competência exclusiva do Congresso Nacional; e de Resoluções, em se tratando de matéria de competência privativa da Câmara ou do Senado, ou mesmo do Congresso Nacional stricto sensu.

Se é verdade que o Poder Legislativo não é o detentor exclusivo da competência para deliberar sobre matéria legislativa, é também verdadeiro que nem todas as suas deliberações são de caráter legiferante. Exerce, outrossim, funções administrativas e mesmo jurisdicionais - processamento e julgamento do Presidente da República por crime de responsabilidade, por exemplo - expressamente previstas na Constituição. Logo, nem todas as deliberações do Congresso Nacional e de suas Casas são de natureza legislativa. Entre 
as deliberações de caráter não legislativas certamente se incluem as trazidas pelo nobre Dep. José Carlos Aleluia, quais sejam, a eleição da Mesa Diretora da Câmara dos Deputados, a escolha de membros do Tribunal de Contas da União e decisão concernente à perda do mandato de integrante desta Casa. A essas hipóteses de deliberações não legiferantes acrescentam-se, ainda, a eleição dos membros da Câmara dos Deputados que irão compor a Comissão Representativa do Congresso Nacional e a escolha dos cidadãos que devem integrar o Conselho da República, conforme entendimento já firmado em decisões anteriores (QO n. 296/2003 e QO n. 336/2004). Não podendo caracterizar-se como legiferantes, tais decisões não são atingidas pela norma constitucional que determina o sobrestamento das deliberações legislativas da Casa em que estiver tramitando Medida Provisória não apreciada pelo Congresso Nacional no prazo de quarenta e cinco dias, contados da publicação. Logicamente, não se há de cogitar em sobrestamento da eleição da Mesa Diretora da Câmara dos Deputados, eis que tal deliberação, além de não legiferante, processa-se fora de qualquer Sessão Legislativa, Ordinária ou Extraordinária, não havendo, portanto, Ordem do Dia a ser trancada.

No que respeita aos demais casos aduzidos pelo preclaro Deputado, por força do disposto nos $\S \S 1^{\circ}$ e $2^{\circ}$ do art. 16 do Código de Ética e Decoro Parlamentar, a REP n. 25/2004, da Mesa Diretora, "contra o Deputado André Luiz, como incurso na previsão do art. 55, II e $\S 1^{\circ}$, da Constituição Federal, combinado com o art. $4^{\circ}$, I, do Código de Ética e Decoro Parlamentar", haverá de ser apreciada antes do PDC n. 1.353/2004, do Senado, que "escolhe o Senhor Luiz Otavio Oliveira Campos para o cargo de Ministro do Tribunal de Contas da União, nos termos do art. $73, \S 2^{\circ}$, II da Constituição Federal", e demais matérias constantes da Ordem do Dia, ressalvadas as Medidas Provisórias e as proposições de autoria do Executivo com solicitação de urgência. Posto isso, defiro a Questão de Ordem n. 536/2005, para firmar o entendimento de que as deliberações não legislativas, entre as quais se incluem a eleição de membros do Tribunal de Contas da União e a decisão sobre a perda de mandato de integrantes desta Casa, não são alcançadas pelo sobrestamento resultante da não-apreciação de Medidas Provisórias no prazo constitucional. Por conseguinte, em obediência ao disposto nos $\S \S 1^{\circ}$ e $2^{\circ}$ do art. 16 do Código de Ética e Decoro Parlamentar, desde já anuncio a inclusão na Ordem do Dia de 4 de maio de 2005, quarta-feira, como item 1 da pauta, a REP n. 25/2004, da Mesa Diretora, "contra o Deputado André Luiz, como incurso na previsão do art. 55, II e $\S 1^{\circ}$, da Constituição Federal, combinado com o art. $4^{\circ}$, I, do Código de Ética e Decoro Parlamentar". Publique-se. Em 28/04/2005. Presidente da Câmara dos Deputados."

Devem ser anunciadas sempre com antecedência as matérias que constarão da Ordem do Dia de uma sessão deliberativa. De fato, a convocação de sessão com o anúncio prévio da(s) matéria(s) que dela constará é pressuposto que decorre da própria 
natureza das Casas Legislativas enquanto órgãos colegiados, pois "os atos dos colegiados legislativos para poder ser-lhes legitimamente imputados, necessitam da reunião conjunta dos seus membros com a finalidade precípua de, conjuntamente, discutir e avaliar os argumentos postos e, conjuntamente, decidir a respeito, mas sempre com base em uma prévia comunicação a todos os membros das matérias a tratar". 229

Afora as determinações constitucionais de inclusão de projetos em Ordem do Dia, são normas regimentais que disciplinam a organização das proposições para discussão e votação em sessão plenária deliberativa; em sessões ditas "de debates" não há Ordem do Dia, pois “debates”, aí, referem-se não à discussão de proposições, mas a discursos parlamentares proferidos nas partes da sessão denominadas Pequeno e Grande Expediente, quando então os parlamentares previamente inscritos podem versar, por tempo que varia entre cinco e quinze minutos, geralmente, assunto de livre escolha. Apartes são permitidos aos discursos somente no período do Grande Expediente, no chamado "pinga-fogo" (Pequeno Expediente) não há apartes.

Há Regimento Interno que faculta ao Presidente da Assembléia dispor livremente sobre a organização das proposições na Ordem do Dia, como o de Minas Gerais (art. 30). Ou que permite, como o da Assembléia de Santa Catarina, "a critério do Presidente da Assembléia, ouvidos os Líderes”, haja, na Ordem do Dia, sobrestamento de proposição (art. 211). Mas, normalmente, a disposição das proposituras em Ordem do Dia segue padrão predefinido por norma regimental. Assim, e.g., em São Paulo, figuram em primeiro lugar as proposições em regime de urgência, seguidas das que tramitam em regime de prioridade e, finalmente, as de tramitação ordinária.

Em cada grupo (urgência/prioridade/tramitação ordinária) a numeração define a ordem de preferência, dando-se prioridade depois às que já estiverem em fase de votação; dentre estas, as que estiverem tramitando em primeiro turno. As proposições em fase de votação adiada precedem as em fase de discussão encerrada que, por sua vez, têm preferência sobre as que estiverem com discussão adiada e estas preterem as que estiverem em fase de discussão inicial. Mesmo assim, pode caber requerimento de preferência para votação ou discussão de uma proposição sobre as de

${ }^{229}$ CAMPOS, Paloma Biglino. Los vícios em el procedimento legislativo.Madri: Centro de Estudios Constitucionales, 1991, p. 79. 
um mesmo regime de tramitação. E, dentro do mesmo regime de tramitação, pode haver ordenação por espécie legislativa, dispondo-se primeiro os projetos de resolução, seguidos dos projetos de lei complementar, lei ordinária, [delegada], decreto legislativo e de resolução Enfim, são inúmeras e diversas as normas de cada Regimento Interno sobre organização das proposições em Ordem do Dia, daí, por certo, a imprescindibilidade de preceito constitucional para dar primazia à discussão e votação de determinada matéria que, no mais das vezes, privilegia as de iniciativa do Executivo.

Porém, mesmo um calendário legislativo anteriormente divulgado, como já se advertiu, não tem o condão de tornar a Ordem do Dia dos trabalhos legislativos um primor de racionalização.

\subsection{Sessões públicas - Quorum de funcionamento}

Uma Constituição republicana lança sobre os Regimentos Internos das Casas Legislativas as luzes para consolidação de uma efetiva publicidade das atividades do Parlamento. As crescentes inovações tecnológicas têm facilitado sobremaneira a possibilidade de os cidadãos acompanharem os trabalhos legislativos (TV, TV-web, Internet, jornal oficial publicando a íntegra das sessões após apanhamento dos debates por taquígrafos), e ajudam a tornar real um imperativo democrático do Estado de Direito, qual a publicidade dos atos decisionais na esfera pública. Norberto Bobbio salienta que "o que vale nos negócios públicos de um regime democrático é a publicidade como regra, o segredo é a exceção". 230

Dando efetividade à exigência democrática da transparência na esfera pública, o constituinte paulista de 1989 preceituou para as sessões realizadas na Assembléia Legislativa uma condição intransponível: que sejam públicas. Trata-se de mandamento constitucional, de maneira que o legislador regimental consolidou as normas atinentes às sessões legislativas sem a possibilidade de prevê-las secretas, em nenhuma hipótese. A Assembléia Legislativa funciona somente em sessões públicas (art. 10). As sessões só podem ser públicas, ao contrário do que ocorre na Câmara dos Deputados ou no Senado que, dependendo da matéria apreciada, admite sessões secretas.

230 Teoria Geral da Política: a filosofia política e as lições dos clássicos. Tradução Daniela Beccaccia Versiani. Rio de Janeiro: Campus, 2000, p. 414. 
Sob a perspectiva de que os constituintes estaduais podem se tornar arautos de novas experiências no sistema federativo, reconhecem-se, nessa dimensão normativa, as vantagens de não se impingir aos Estados-membros padrões de incondicional observância no processo legislativo, onde, e.g., a possibilidade de sessões secretas, tal qual permitido pelo modelo federal, afasta do cânone republicano os trabalhos legislativos.

A presença do parlamentar é imprescindível, pois informa todo o funcionamento das Casas Legislativas. Contudo "a luta contra a falta de assiduidade é um dos grandes desafios que os modernos sistemas parlamentares devem enfrentar e, em maior ou menor escala, todos têm reagido a isso". ${ }^{231}$ Essa constatação e advertência de Francisco Caamaño Domingues é bem o nó górdio dos trabalhos legislativos; merecendo do constituinte, desde 1934, medida extrema: punição com a perda do mandato. Todavia, a perda só se dará, hoje, se o parlamentar faltar a mais de um terço das sessões ordinárias anuais (art. 55, III, da CF), excluídas as licenças e as faltas justificadas. Dir-se-á que tanta condescendência torna a punição um arremedo de sua real pretensão, pois extravasa em generosidade para com os faltosos. Pífia, então, a norma que tem a pretensão de combater o absenteísmo parlamentar com a perda do mandato para aquele que, pasmem, faltar a um terço das sessões legislativas ordinárias, excluídas as licenças e as faltas justificadas. Esse preceito, ex vi do art. $27, \S 1^{\circ}$ da Constituição Federal, aplica-se também aos Deputados e às Deputadas Estaduais.

De outra forma, bem mais severa, vem disciplinada a mesma questão no Estatuto dos Deputados portugueses (art. $\left.8^{\circ} .1 . b\right)$ e no Regimento da República de Portugal (art. $\left.4^{\circ} .1 . b\right)$, onde a perda do mandato parlamentar dar-se-á se houver ausência “a quatro reuniões do Plenário por cada sessão legislativa” anual.

Para fugir de interpretação abrangente do conceito de presença do parlamentar no recinto do Plenário ou nas dependências da Casa Legislativa, os Regimentos Internos preceituam que é consignada com a sua assinatura, em Plenário, em documento próprio ("lista de comparecimento"), onde se especificam a data e o número da sessão (ordinária ou extraordinária); ou mediante registro pessoal em painel eletrônico situado no Plenário.

${ }^{231}$ DOMINGUES, Francisco Caamaño. El mandato parlamentario. Madri: Congreso de los Diputados, 1991, p. 235. 
As presenças de parlamentares comporão o quorum de abertura dos trabalhos ou de instalação da sessão. Não preenchido o quorum inicial para instalação da sessão, ela, ipso facto, sequer existirá; se abertura houver, sem observância desse requisito essencial para o funcionamento do órgão colegiado, estar-se-á diante de vício insanável. Inexistindo quorum para abertura dos trabalhos e, obviamente, não se realizando a sessão, atribuir-se-á falta aos ausentes para efeito de perda do mandato por não comparecimento a mais de um terço das sessões ordinárias, e para desconto de jeton $^{232}$. E, como prazos regimentais podem ser contados, igualmente, por sessão ordinária realizada, ficam eles, pois, assim, pela ausência parlamentar, prorrogados.

O quorum para abertura é também o da continuidade da sessão, bastando para verificá-lo, no decorrer das atividades parlamentares, requerimento de um dos pares ou de Líder, como estiver normatizado no Regimento Interno. Ao presidente da sessão cabe, ictu oculi, deferi-lo ou não. Se, num golpe d'olhos, o Presidente verificar inexistência de quorum, mandará fazer verificação de presença, mediante processo nominal de chamada dos parlamentares e, se, ao seu término, não se constatar quorum para continuidade da sessão, dá-la-á, então, por encerrada; ou, na locução regimental das Casas Legislativas, dar-se-ão os trabalhos por levantados (levantada a sessão).

Outro é o quorum de deliberação, como se verá adiante.

Havendo quorum para abertura dos trabalhos legislativos, mesmo quando a sessão seja de debates e não deliberativa, transcorrem-se os prazos regimentais condicionados à realização de sessão que, em Minas Gerais, e.g., recebe a denominação de reunião. À guisa de conhecimento, traz-se à colação o quorum de instalação das sessões nas Assembléias Legislativas, de acordo com os respectivos dispositivos regimentais: Acre, 5 parlamentares (art. 124, § 2º); Alagoas, 1/3 (art. 134); Amapá, 8 parlamentares (art. 11, § 2º); Amazonas, $1 / 5$ (art. 85); Bahia, 1/3 (art. 86); Ceará, 1/3 (art. 170, $\S 1^{\circ}$ ), Espírito Santo, 1/10 (art. 105, § $3^{\circ}$ ); Goiás, 1/3 (art. 102, § 2º); Maranhão, 1/5 (art. 101, § 2º); Mato Grosso, 1/3 (art. 98); Mato Grosso do Sul, 1/4 (art. 179); Minas Gerais, 1/3 (art. 19, § $1^{\circ}$ ); Pará, $1 / 4$ (art. 119, § 2º); Paraíba, 1/7 (art. 61, § $1^{\circ}$ ); Paraná, 1/10 (art. 88); Pernambuco, 1/5 (art. 144, § $1^{\circ}$ ); Piauí, 1/3 (art. 81, § $1^{\text {o }}$ );

\footnotetext{
${ }^{232}$ Na definição do Dicionário Houaiss da Língua Portuguesa: "Remuneração dada aos membros de órgãos colegiados por sessão a que comparecem. Etimologia: fr. jeton ... (1846) 'gratificação que se concede a membro de uma sociedade pela sua participação em uma assembléia', do fr. jeter 'lançar, projetar' + -on."
} 
Rio de Janeiro, 1/10 (art. 71); Rio Grande do Norte, 1/3 (art. 162); Rio Grande do Sul, 1/4 (art. 99); Rondônia, 1/3 (art. 123, § $1^{\circ}$ ); Roraima, 1/3 (art. 144); Santa Catarina, 1/5 (art. 96, § $3^{\circ}$ ), São Paulo, $1 / 4$ (art. 112 e art. 10 da CE); Sergipe, 1/6 (art. 138, § 2º ; e Tocantins, $1 / 3\left(\operatorname{art} .90, \S 2^{\circ}\right)$.

Para a legislatura que se iniciou em 2007 e terminará em 2011, as Assembléias Legislativas possuem a seguinte composição com os respectivos quóruns de instalação de sessão:

\begin{tabular}{|c|c|c|}
\hline \multicolumn{3}{|c|}{ ASSEMBLÉIAS LEGISLATIVAS } \\
\hline ESTADO & $\mathbf{N}^{\circ}$ DE PARLAMENTARES & QUORUM DE ABERTURA \\
\hline 1. São Paulo & 94 & 24 \\
\hline 2. Minas Gerais & 77 & 26 \\
\hline 3. Rio de Janeiro & 70 & 7 \\
\hline 4. Bahia & 63 & 21 \\
\hline 5. $\quad$ Rio Grande do Sul & 55 & 14 \\
\hline 6. Paraná & 54 & 6 \\
\hline 7. Pernambuco & 49 & 10 \\
\hline 8. Ceará & 46 & 16 \\
\hline 9. Maranhão & 42 & 9 \\
\hline 10. Goiás & 41 & 14 \\
\hline 11. Pará & 41 & 11 \\
\hline 12. Santa Catarina & 40 & 8 \\
\hline 13. Paraíba & 36 & 6 \\
\hline 14. Espírito Santo & 30 & 3 \\
\hline 15. Piauí & 30 & 10 \\
\hline 16. Alagoas & 27 & 9 \\
\hline 17. Mato Grosso & 24 & 8 \\
\hline 18. Sergipe & 24 & 4 \\
\hline 19. Rio Grande do Norte & 24 & 8 \\
\hline 20. Amazonas & 24 & 5 \\
\hline 21. Acre & 24 & 5 \\
\hline 22. Mato Grosso do Sul & 24 & 6 \\
\hline 23. Rondônia & 24 & 8 \\
\hline 24. Amapá & 24 & 8 \\
\hline 25. Roraima & 24 & 8 \\
\hline 26. Tocantins & 24 & 8 \\
\hline
\end{tabular}

\subsection{Turnos de discussão e votação}

As proposições são submetidas a turno de discussão e votação. A discussão é a fase destinada aos debates em Plenário e serve a vários escopos, inclusive o de ter a pretensão de convencimento: o parlamentar que discute a favor de uma proposição, além de afirmar a convicção do seu voto favorável, pode buscar convencer os demais parlamentares, que votariam contra, a votar como ele, favoravelmente. Manoel Gonçalves Ferreira Filho anota, como legado do processo legislativo clássico, pressuposto das delongas na discussão: dos debates nasceria a luz. ${ }^{233}$ Mas a conseqüência insofismável dos debates parlamentares reside na reafirmação de que se trata de um processo democrático e transparente, dimensionado na esfera pública,

233 Do processo legislativo. 2. ed. São Paulo: Saraiva, 1984, p. 88. 
antecedendo a fase decisional. Discutir e decidir publicamente faz parte da singular metodologia de trabalho do Legislativo. ${ }^{234}$ Neste Poder, há uma peculiar separação entre os momentos de "produção" e a "encenação" das decisões para consecução das suas funções precípuas: "as decisões podem ser tomadas em reuniões de gabinete, em comissões técnicas, mas a encenação da tomada de decisão é pública, possibilitando ao povo uma participação política atuante dentro do sistema”, observa Tércio Sampaio Ferraz Jr. ${ }^{235}$

Exceto em relação às propostas de emenda à Constituição, submetidas a dois turnos de discussão e votação por força de preceito constitucional, cabe aos Regimentos Internos das Assembléias Legislativas a disciplina dos turnos a que uma proposição é submetida, assim como a fixação de prazos para discussão se faz igualmente por norma regimental.

O Regimento Interno da Assembléia Legislativa de Goiás estabelece que nenhum projeto de lei ou de resolução poderá ser discutido, sem que esteja instruído para figurar na Ordem do Dia com, pelo menos, vinte e quatro horas de antecedência. Determina, ainda, que todo projeto de lei passará por três discussões e votações, e o intervalo de uma discussão para outra não poderá ser inferior a vinte e quatro horas (art. 157). A primeira discussão e votação de qualquer projeto de lei versará sobre “o parecer da comissão técnica competente, bem como a utilidade e constitucionalidade do projeto em geral, sem se entrar no exame de cada um de seus artigos". Aprovado em primeiro turno, o projeto será submetido à segunda discussão e votação, quando, então, “debater-se-á cada artigo do projeto e, sendo oferecidas emendas, a votação será adiada até que a comissão respectiva exare parecer" (art. 162). Na terceira discussão "debaterse-á o projeto em globo" (art. 166). Se aprovado, o projeto com as emendas será objeto, ainda, de mais uma votação, agora da redação proposta por comissão técnica (art. 167). Concede-se ao parlamentar, em cada turno, o prazo de dez minutos para discussão, não podendo exceder de nove o número de parlamentares "para discutir e encaminhar voto" (art. 131).

\footnotetext{
234 A Constituição do Estado de São Paulo, promulgada em 05 de outubro de 1989, não admite sessões reservadas ou secretas e preceitua:

“Art. 10 - A Assembléia Legislativa funcionará em sessões públicas, presente, pelo menos, um quarto de seus membros."

235 FERRAZ JR., Tércio Sampaio. Democracia e Participação, in Curso de Introdução à Ciência Política. Brasília : Editora Universidade de Brasília, 1979, p. 63.
} 
Discussão e votação em dois turnos prescrevem os Regimentos Internos das Assembléias Legislativas do Amazonas, para os projetos de lei complementar (art. 181); Bahia, para todas proposições e com interstício de cinco dias entre um turno e outro (arts. 148 e 150); Ceará, com interstício de quarenta e oito horas para as proposições em tramitação ordinária e sem interstício no regime de urgência (art. 247); Espírito Santo (art. 174); Minas Gerais (art. 176); Mato Grosso do Sul (art. 266); Paraná (art. 142); Pernambuco (art. 218); Piauí (art. 126); Rio de Janeiro (art. 126); e Santa Catarina, para os projetos de lei complementar ou ordinária de origem parlamentar (art. 213).

Exceto em projetos de lei complementar e de iniciativa popular, a Assembléia Legislativa do Amazonas estabelece turno único de discussão e votação.

Os Regimentos Internos das Assembléias Legislativas prevêem o encerramento da discussão nas hipóteses de (a) ausência de oradores; (b) decurso de prazos regimentais ou constitucionais; ou (c) por deliberação do Plenário.

Na primeira hipótese, não havendo oradores inscritos, ou não havendo mais oradores inscritos, dá-se a discussão por encerrada. Na segunda, presume-se encerrada a discussão, mesmo quando ainda houver oradores inscritos, em virtude do esgotamento de prazos regimentais previamente fixados. Assim, por exemplo, encerrase a discussão da proposição após ter ela figurado na Ordem do Dia de seis sessões, como ocorre nas Assembléias Legislativas do Pará (art. 204) e de Minas Gerais (art. 244). O Regimento Interno da Assembléia Legislativa do Pará considera encerrada a discussão depois de transcorridos os prazos constitucionais. É o que ocorre quando o Governador, ou mesmo o Presidente do Tribunal de Justiça, solicita tramitação em regime de urgência para projetos de sua autoria (art. 107, da Constituição Estadual). Se a Assembléia Legislativa não se manifestar em até quarenta e cinco dias sobre a proposição, será ela incluída na Ordem do Dia para que se ultime a votação. No processo legislativo paraense, o projeto de lei de autoria do Governador ou de autoria do Tribunal de Justiça, com solicitação de urgência constitucional, caso não for deliberado em até quarenta e cinco dias, passa a figurar em Ordem do Dia no quadragésimo sexto dia apenas para votação, presumindo-se ocorrida a discussão caso ela não tenha sido feita até então.

E, na terceira hipótese, encerra-se a discussão por deliberação do Plenário. Trata-se, evidentemente, de uma decisão da maioria parlamentar que compõe o 
Plenário, por isso mesmo, as normas regimentais haverão de garantir oportunidade para que a minoria possa utilizar tempo razoável de discussão. Todavia, o juízo dessa razoabilidade não deixa de ser ainda da maioria, que aprova norma regimental dispondo sobre as condições que devem ser superadas para que haja a deliberação do Plenário sobre encerramento de discussão. Assim, e.g.: (1) "O requerimento de encerramento de discussão será submetido à votação, desde que seis oradores tenham discutido a proposição." (art. 248, parágrafo único, Regimento Interno da Assembléia de Minas Gerais); (2) "O encerramento da discussão dar-se-á mediante deliberação do Plenário, a requerimento de um terço dos Deputados, após a matéria haver sido discutida em duas reuniões consecutivas, no mínimo.” (art. 217, III, Regimento Interno da Assembléia de Pernambuco); (3) “Ainda que haja oradores inscritos, a discussão poderá ser encerrada a requerimento escrito de qualquer Deputado, desde que a matéria esteja sendo debatida há duas sessões e tenham falado, além dos relatores da proposição, cinco Deputados.” (art. 127 do Regimento Interno da Assembléia do Rio Grande do Sul); (4) “A discussão poderá ser encerrada por deliberação do Plenário, a requerimento de um terço, pelo menos, dos membros da Assembléia, após seis horas de discussão, para as proposições em regime de urgência; nove horas, para as em regime de prioridade; $e$ doze horas, para as de tramitação ordinária" (art. 194, parágrafo único, da XIII Consolidação do Regimento Interno da Assembléia de São Paulo).

\subsubsection{Prazos de discussão fixados nos Regimentos Internos e condiçõespara seu encerramento}

As Casas Legislativas dos Estados-membros da Federação brasileira são chamadas a manifestar-se sobre variadas questões de interesse regional. Em projetos de iniciativa do Executivo, por mais que tenha havido consultas, pesquisas, assessoria para sua formulação - projetos, os quais, são engendrados, quase sempre, em ambientes restritos -, há, sempre, oportuno espaço para sua crítica e seu aprimoramento em ambiente parlamentar, malgrado a crítica de que o Parlamento como um todo, e, portanto, as Assembléias Legislativas ficam aí também incluídas, deixou de ser locus de efetiva tomada de decisões. Jürgen Habermas, indicando mudança na esfera pública, salienta que o Partido Político passou a ter proeminência em detrimento do mandato parlamentar livre. Apregoa que "o Parlamento tende a se tornar um local em que esses funcionários do partido [político], presos a mandatos, se encontram para fazer com que 
sejam registradas decisões já tomadas" no âmbito do Partido Político. ${ }^{236}$ Anota, ainda, que "o próprio Parlamento desenvolveu-se de acordo com isso, deixando de ser a corporação que discutia, pois o mero 'amém' parlamentar de resoluções previamente negociadas por baixo do pano não obedece apenas a uma prescrição formal: serve para demonstrar, para fora, a vontade do partido". ${ }^{237}$ E, citando descrição de Friesenhahn, procura demonstrar a mudança na esfera das decisões políticas:

"De uma 'assembléia de homens sábios, escolhidos como personalidades únicas de camadas privilegiadas, que procuravam persuadir-se mutuamente com argumentos, através de discussões públicas, na suposição de que a decisão tomada, então, pela maioria, seria o verdadeiro e o correto para o bem-estar do povo', o Parlamento passou a ser a 'tribuna pública em que, perante todo o povo que, através do rádio e da televisão, participa de modo todo especial nessa esfera pública, o governo, com os partidos que o apóiam, apresenta e defende a sua política perante o povo, enquanto a oposição ataca essa política com a mesma abertura, apresentando alternativas."238

No magistério de Jorge Miranda, "a competência legislativa do Parlamento, num Estado de Direito democrático, funda-se, simultaneamente, na idéia democrática de que a lei, dirigida a todo o povo, deve ser votada pelos seus representantes eleitos; na idéia liberal do debate público e contraditório em que se espera pôr a razão a plena luz; e na idéia pluralista de que uma assembléia com diversidade de opiniões e interesses é mais apta para tomar as grandes deliberações do que qualquer outro órgão". 239

À recorrente crítica de que as deliberações sobre matéria em trâmite legislativo já teriam sido tomadas em outras esferas de poder, e de que há retardamento de decisões no âmbito do Legislativo acerca de temas que exigiriam pronta decisão na gestão do interesse público, opõe-se a constatação, cada dia mais efetiva, de que, na esfera do Legislativo, os direitos e garantias a serem tutelados podem abranger, muitas vezes, uma amplitude ainda maior do que a que originalmente estava sendo albergada na proposição original, formulada no âmbito do Executivo. Por mais críticas que possa merecer a morosidade das decisões no âmbito do Legislativo, ela (a morosidade) já não tem sido mais mote para "alavancar" açodada decisão parlamentar qualquer, senão a decorrente de apreciação mais aprofundada sobre o assunto, merecendo reparos de

\footnotetext{
${ }^{236}$ Mudança estrutural da esfera pública. Tradução de Flávio Kothe. Rio de Janeiro: Tempo Brasileiro, 2003, p. 240

${ }^{237}$ Idem, ibidem.

${ }^{238}$ Id. ib.

${ }^{239}$ Manual de direito constitucional. 2. ed., Coimbra: Coimbra ed.,1998, v. IV, p. 332.
} 
aprimoramento à proposta original consubstanciados mediante emendas parlamentares, sejam elas aditivas, supressivas, modificativas, aglutinativas ou até substitutivas.

Assim, os tempos de discussão fixados pelos Regimentos Internos em ordem a, depois dela, haver apreciação e deliberação de proposituras pode parecer "demorado", ou não. Todavia, a demora é relativa, pois decorrente do observador que assim quer, ou não, compreendê-la. E não se pode aqui também, deixar de anotar, num tom quase irônico, o comentário do eminente jurista Manoel Gonçalves Ferreira Filho ao pressuposto de tanto tempo dedicado à discussão de proposituras nos Parlamentos, referindo-se ao processo legislativo clássico, mas do qual a delonga nas discussões é justificada pela presunção de que "da discussão nasça a luz". 240

Seja como for, o tempo de discussão de uma proposição é matéria atinente à disciplina regimental. São os Regimentos Internos das respectivas Assembléias Legislativas que estipulam o tempo de debate de uma determinada proposição, como logo abaixo se demonstra.

Assente-se, antes, que a discussão de proposição é feita no seu todo, inclusive emendas. Evidente que somente será objeto de discussão a proposição constante de Ordem do Dia. Observados os prazos estipulados nos Regimentos, cada Deputado previamente inscrito tem o direito de falar uma vez sobre a mesma proposição, exceto se receber, por cessão, o tempo de outro(s) parlamentar(es). Enquanto houver oradores inscritos para falar a favor e contra, observa-se a alternância.

O encerramento da discussão se dá pela ausência de oradores inscritos ou pelo decurso dos prazos regimentais, que pode defluir da circunstância de a proposição ter figurado em Ordem do Dia de um número determinado de sessões. No entanto, mesmo havendo oradores inscritos, a discussão pode ser encerrada por deliberação do Plenário, em geral, como se verá infra, a requerimento de um terço dos membros da Assembléia.

Por imperativo prático, vez que a dinâmica da vida parlamentar hodierna exige dos representantes quase $o$ dom da ubiqüidade, tantas as atividades concomitantes, admite-se o voto de quem não assistiu a toda a discussão.

O Regimento Interno da Assembléia Legislativa de Minas Gerais estipula que nenhum projeto - excetuados os de lei orgânica ou equivalentes a código -

\footnotetext{
${ }^{240}$ Do processo legislativo. 2. ed. São Paulo: Saraiva, 1984, p. 88.
} 
permanecerá em Ordem do Dia para discussão, em cada turno, por mais de seis sessões, ou reuniões (art. 244). Para cada orador inscrito concede-se a palavra por sessenta minutos (art. 246).

Em comando idêntico, o Regimento Interno da Assembléia do Pará: excetuados os projetos de lei orgânica, diz que nenhuma proposição permanecerá em Ordem do Dia, para discussão, em cada turno, por mais de seis reuniões (art. 204). Para discutir um projeto o Deputado dispõe de vinte minutos (art. 205).

Requerimento de encerramento de discussão de projeto de lei somente será submetido à votação, desde que um terço dos Deputados, ou Líderes que assim os representem, tenha discutido a proposição, ou, desde que, no mínimo, quatro oradores tenham assomado à tribuna (art. 140). É o que preceitua o Regimento Interno da Assembléia Legislativa da Paraíba. Para discutir um projeto o Deputado dispõe de vinte minutos; se autor ou relator da respectiva proposição, faculta-se-lhe a palavra pelo dobro do tempo (art. 136).

No Estado do Paraná, o Regimento Interno da Assembléia Legislativa estabelece que nenhum projeto de lei, de resolução ou de decreto legislativo será aprovado senão depois de ter passado por duas discussões (art. 142); exigindo-se, para sua deliberação, a inclusão em Ordem do Dia, "pelo menos vinte e quatro horas antes" (art. 143). A primeira discussão versa, exclusivamente, sobre a constitucionalidade e a legalidade do projeto; a segunda, sobre o mérito (arts. 144 e 145). Em cada discussão, franqueia-se a palavra por, no máximo, dez minutos aos Deputados inscritos (art. 152).

Pelo Regimento Interno da Assembléia Legislativa de Santa Catarina o Deputado só poderá falar uma vez e por dez minutos na discussão de qualquer proposição, podendo ter o prazo prorrogado uma vez, pelo mesmo tempo, se for autor ou relator da proposição (art. 237). Se subscrito por um terço dos Deputados ou por Líderes de Bancada que representem essa grandeza, o requerimento de encerramento de discussão pode ser submetido a votos, a qualquer momento (art. 241, parágrafo único).

No Tocantins os projetos de lei, de decreto legislativo e de resolução passam por dois turnos de discussão e votação. O interstício entre um turno e outro é de vinte e quatro horas (art. 137). Na discussão "serão inscritos até seis Deputados, mais Líderes e Autor, observada a proporcionalidade partidária", e fazem uso da palavra por dez minutos (arts. 153 e 155). 
O Regimento Interno da Assembléia Legislativa do Rio Grande do Sul dispõe que o Deputado, na discussão de uma proposição, só poderá falar uma vez e pelo prazo de cinco minutos (art. 123). Ainda que haja oradores inscritos, a discussão pode ser encerrada a requerimento escrito de qualquer Deputado, desde que a matéria esteja sendo debatida há duas sessões e tenham falado, além dos relatores da proposição, cinco Deputados. Se aprovado o requerimento de encerramento, ainda poderá discutir a proposição um Deputado de cada Bancada cujos integrantes não tenham sobre ela se pronunciado. E quando a proposição estiver sendo debatida por partes (e.g., títulos, capítulos, seção), o encerramento da discussão de cada uma delas poderá ser requerido a qualquer tempo após falarem, além dos relatores, três Deputados (art. 127).

Em Rondônia há duas discussões e votações para projetos de lei, devendo decorrer, entre as discussões, intervalo de vinte e quatro horas (arts. 197 e 199). Encerra-se a discussão, por deliberação do Plenário, se a matéria já tiver sido discutida em sessão anterior e sobre ela já tiver falado pelo menos quatro oradores. Cada orador dispõe de dez minutos (arts. 203 e 212).

Discute-se em dois turnos e cada parlamentar dispõe de "prazo máximo de cinco minutos" no debate de projetos (arts. 214, § $2^{\circ}, 217$ e 218). O encerramento da discussão se dá, também, "se a matéria já houver sido discutida em sessão anterior" (art. 225). É o que estatui o Regimento Interno da Assembléia Legislativa de Roraima.

Em cada turno de discussão o parlamentar dispõe de dez minutos (art. 163). O encerramento da discussão pode ser requerido por um terço dos Deputados, ou por Líderes que representem esse número, "tendo sido a proposição discutida, pelo menos, por quatro oradores" (art. 167, parágrafo único). É o que estabelece o Regimento Interno da Assembléia Legislativa do Piauí.

É de quinze minutos o tempo concedido a parlamentar na Assembléia Legislativa do Amazonas para discutir projetos (art. 194). Por deliberação do Plenário encerra-se também a discussão desde que "tenham falado o Autor, o Relator, o Autor de voto separado ou vencido, e, pelo menos, um orador de cada bancada, salvo desistência ou ausência", a requerimento de um terço dos membros da Assembléia (art. $195)$. 
O Regimento Interno da Assembléia Legislativa da Bahia ressalva que haverá discussão única para projeto de iniciativa governamental "com prazo fixado de deliberação ou proposição com urgência regimental aprovada", projeto de criação de cargos na Assembléia e nos Tribunais, lei delegada, projeto de decreto legislativo, projeto de resolução, projeto vetado, concessão de crédito, intervenção em Município, indicação, requerimento sujeito à discussão e parecer sujeito à discussão independente. Para as demais proposições, são duas as discussões, afora a da redação final (art. 148). Nos projetos sujeitos a duas discussões, encerrada a primeira, reabre-se a pauta por cinco dias, retornando a proposição às Comissões, se houver recebido emendas. Caso contrário, será a matéria incluída na Ordem do Dia para última discussão (art. 150). Cada parlamentar pode usar da palavra por vinte minutos; se autor ou relator da matéria, o dobro do tempo (art. 154). O encerramento da discussão ocorre "após três sessões, se assim deliberar o Plenário", no caso de matéria em regime de urgência (art. 157).

Na Assembléia Legislativa do Ceará há interstício de quarenta e oito horas entre a primeira e a segunda discussão, salvo para "as proposições em regime de urgência, que serão apreciadas na sessão imediata" (art. 247). Se a matéria já tiver sido discutida, no mínimo, por quatro oradores e um terço dos Deputados ou Líderes que representem este número o solicitar, o Plenário pode encerrar a discussão (art. 246), onde cada parlamentar dispõe de dez minutos (art. 244).

Submetidas a duas discussões (art. 174), cada orador dispõe de dez minutos e pode haver encerramento da discussão das proposições se a matéria tiver sido discutida em sessão anterior, no mínimo, por quatro oradores (art. 184 e 186), diz o Regimento Interno da Assembléia Legislativa do Espírito Santo.

Concede-se a palavra por quinze minutos para cada parlamentar que quiser discutir um projeto na Assembléia Legislativa de Pernambuco (art. 215). Entre a primeira e a segunda discussão há interstício de quatro reuniões, salvo para projetos em regime de urgência, "que poderão ser incluídos na Ordem do Dia da reunião imediata, após sua publicação" (art. 218). O encerramento dos debates pode ocorrer por decisão do Plenário, a requerimento de um terço dos Deputados, depois de a matéria ter sido discutida em duas reuniões consecutivas, no mínimo (art. 217).

Em turno único de discussão e votação de proposição, o Regimento Interno da Assembléia Legislativa do Rio Grande do Norte garante a cada parlamentar 
inscrito dez minutos para discutir proposição (art. 248). Encerra-se a discussão somente pela ausência de oradores inscritos (art. 249).

O Regimento Interno da Assembléia Legislativa do Estado de Mato Grosso do Sul assegura a cada parlamentar, nos dois turnos de discussão e votação das proposições, dez minutos para discutir (arts. 266 e 276). Após a fala de dois oradores, o Plenário pode encerrar a subfase da discussão (art. 286).

Para discutir projetos em tramitação ordinária, os parlamentares fluminenses dispõem de quinze minutos (art. 156). Entre a primeira e a segunda discussões haverá um interstício de quarenta e oito horas, podendo ser reduzido à metade por solicitação de qualquer Deputado e deliberação do Plenário. E, a requerimento da maioria absoluta dos Deputados, poderá ser dispensado o interstício para a segunda discussão (art. 161). No concernente ao encerramento da discussão, o Regimento Interno da Assembléia Legislativa do Rio de Janeiro estabelece: "A requerimento assinado por lideranças partidárias poderá uma matéria, quando iniciada sua discussão, permanecer na pauta para recebimento de emendas, pelo prazo máximo de cinco dias, sem que se encerre a sua discussão, passando-se, neste caso, à matéria seguinte" (art. 159).

Na Assembléia Legislativa do Estado de São Paulo o parlamentar dispunha, até novembro de 2007, enquanto vigorou a XII Consolidação do Regimento Interno, de sessenta minutos para discutir as proposições em regime ordinário de tramitação e também as em regime de prioridade. Nas proposições em regime de urgência, o tempo franqueado a cada orador era de trinta minutos (art. 190). Esses prazos foram reduzidos pela metade quando passou a viger, em 13 de novembro de 2007, a XIII Consolidação. O encerramento da discussão, a requerimento de um terço dos membros da Assembléia, podia ocorrer desde que já discutidas 12 horas as proposições em regime de urgência; 18 horas, as em regime de prioridade; e 24 horas, as de tramitação ordinária, preceituava o Regimento Interno paulista (art. 194 da XII Consolidação regimental). Esses prazos, igualmente, foram cortados pela metade, a partir da vigência da XIII Consolidação do Regimento Interno. Não que o legislador regimental só tivesse concluído que o prazo para discussão era demasiado elástico; mas também porque o tempo de duração dedicado às sessões extraordinárias, que era de até cinco horas, também sofreu redução pela metade, passando a ser de duas horas e meia, e se tornarou improrrogável. Racionalizaram-se, pois, os trabalhos legislativos. Mesmo assim, na 
Ordem do Dia da última sessão ordinária de 2008, constavam 2009 itens, ou seja, 2009 proposições para discussão e votação, ou somente votação.

\subsubsection{Emenda aglutinativa}

Recente no panorama regimental das Assembléias Legislativas, a emenda aglutinativa, juntamente com a aditiva, a supressiva, a modificativa e a substitutiva, figura como proposição acessória.

A emenda aglutinativa resulta da fusão de outras emendas ou submendas, ou destas com o texto da proposição principal, em perspectiva a fazer com que haja aproximação dos respectivos conteúdos.

Peculiaridade dessa proposição são as exigências formais para sua formulação e a oportunidade de sua apresentação.

Concebida como derradeiro momento para composição de interesses no processo legislativo, a emenda aglutinava exige subscrição de dois terços dos membros da Assembléia Legislativa, ou de Líderes que representem esse número, como estatuído no inciso IV do art. 175 da XIII Consolidação do Regimento Interno paulista. Vê-se, pelo número significativo de subscritores, que a matéria a ser por ela disciplinada passou por um crivo de consensualidade - não se exige a unanimidade - , o de dois terços dos parlamentares; vedando-se, como se veda, a subscrição, pelo mesmo parlamentar ou Líder, a mais de uma emenda, evidente constatar-se que pode haver, quando houver, uma só emenda aglutinativa no processo legislativo de determinada proposição.

O momento de sua apresentação, também indicativo de derradeira oportunidade para ser incluída no processo legislativo matéria nova, transcorre após o encerramento da discussão da proposição principal e antes de iniciada a votação. Em função dessa singularidade, a emenda aglutinativa é submetida a votos, independentemente de parecer de qualquer Comissão técnica ou de mérito da Casa Legislativa. Não há, pois, sobre o conteúdo de emenda aglutinativa qualquer controle interno de constitucionalidade, financeiro-orçamentário ou de mérito. Dir-se-á, então, que esse controle poderia ser feito pela maioria dos membros que compõem o Plenário. No entanto, se dois terços já subscreveram a emenda - presume-se, com a pretensão de aprová-la -, a fortiori haverá de se concluir que dificilmente compor-se-ia, no mesmo colegiado, outra maioria capaz de reprová-la. Por isso mesmo, presume-se que o 
conteúdo de emenda aglutinativa não tenha óbices de natureza constitucional, financeiro-orçamentário e tampouco de mérito. Daí ser verdadeira a assertiva de que nessa proposição se deposita a derradeira oportunidade para se tentar a composição de interesses conflituosos no processo legislativo sobre determinada matéria. Notadamente quando se concebe uma emenda aglutinativa com natureza de substitutivo.

\title{
7.7 Deliberação - Critério das decisões na democracia representativa
}

No artigo n. 10 de $O$ Federalista, James Madison, delineando os principais traços de democracia deliberativa, fazia a seguinte reflexão: "como a história havia demonstrado que as democracias estavam continuamente sujeitas a tumulto, desordem e confusão; que os cidadãos, freqüentemente, sacrificam seu raciocínio independente pelas promessas convenientes de oradores astutos; e que os direitos das minorias (fossem econômicas, religiosas ou étnicas) eram flagrantemente violados por maiorias tirânicas. E, como esses defeitos eram endêmicos nas democracias diretas, quaisquer que fossem suas condições históricas, culturais ou sociais; isso ensinou os autores da Constituição que a regra da maioria não estava fadada a falhar, deixando como alternativas viáveis somente o governo de 'um' ou o governo de 'alguns', mas que se devia sim fazer com que a maioria governasse mediante representantes. Isto apresentaria dois benefícios. Primeiro, permitiria que um só governo se estendesse sobre uma população e um território muito maiores, tornando, assim, mais difícil que uma maioria injusta viesse a unir-se e executar seus desígnios". ${ }^{241}$ Segundo,

\begin{abstract}
"refinaria e aumentaria as opiniões do público ao passá-las através de um corpo selecionado de cidadãos, cuja sensatez poderia discernir melhor os verdadeiros interesses de seus país e cujo patriotismo e cujo amor à justiça apresentariam menor probabilidade de sacrificá-lo a considerações temporárias ou parciais. Sob tal regulamentação, poderia muito bem acontecer que a voz do público, pronunciada pelos representantes do povo, viesse a ser mais consoante com o bem público do que se pronunciada pelo próprio povo, reunido para esse fim". ${ }^{242}$
\end{abstract}

\footnotetext{
${ }^{241}$ BESSETTE, Joseph M. Democracia deliberativa: o princípio da maioria no governo republicano, in A Constituição Norte-Americana. Rio de Janeiro: Forense Universitária, 1986, p. 291-292.

${ }^{242}$ HAMILTON, Alexander; MADISON, James; JAY, John. O Federalista. Trad. Reggy Zacconi de Moraes, Rio de Janeiro: Nacional de Direito, 1959, n. 10. p. 39-44.
} 
As decisões na democracia representativa são tomadas pela maioria. Em colegiados timbrados pela representação, há registros históricos de que na Idade Média a representação em ordens religiosas já utilizava como técnica de tomada de decisão o voto da maioria absoluta e da maioria de dois terços. ${ }^{243}$ Eis, pois, que na democracia deliberativa, o quorum utilizado também é esse. Mas não só. Faz-se uso da maioria simples e de outras maiorias qualificadas, além da de dois terços.

A Constituição Federal estabelece o critério de deliberação por maioria: maioria de votos, desde que presente a maioria absoluta dos membros (art. 47). Este critério aplica-se no âmbito das Comissões e nas plenárias das respectivas Casas Legislativas, inclusive as estaduais.

Trata-se de norma principiológica decorrente de premissa republicana e democrática, a de que na res publica a vontade prevalente seja a da maior parte do conjunto dos representantes. Isto ocorre no processo legislativo representativo, não no autocrático nem no direto e tampouco no semidireto, conforme esclarece Nelson de Sousa Sampaio. ${ }^{244}$

Dentre os quóruns previstos na Constituição Federal, além da maioria simples $(26 \%$, ou o número inteiro imediatamente superior à metade da maioria absoluta), absoluta (51\%, ou o número inteiro imediatamente superior à metade), qualificada de três quintos $(60 \%)$ e de dois terços $(66,6 \%)$, há o de dois quintos $(40 \%)$,

243 FINER, S. E. A história do governo - as épocas intermédias. Portugal: Publicações EuropaAmérica, 2004, v. II, p. 1088-1089.

${ }^{244}$ Processo legislativo. 2. ed. Belo Horizonte: Del Rey, 1996, p. 36-55:

Autocrático: o governante fundamenta em si próprio a competência para outorgar leis. Não é expressão da atividade legiferante do corpo de cidadãos, seja diretamente, seja por intermédio de seus representantes. O processo autocrático de legislar manifesta-se nas monarquias absolutas, nas ditaduras e nos governos de fato.

Direto: pelo próprio povo. Nas cidades-estados greco-romanas; em Esparta, a assembléia popular, denominada Apella, votava, sem discutir, por sim ou não, de viva voz, em reuniões ao ar livre, fora da cidade; em Atenas, a assembléia popular, denominada Ecclesia decidia, após parecer do Conselho dos 500, uma espécie de grande comissão permanente da Ecclesia, cujos membros eram designados anualmente, por sorteio; na Roma antiga, 'lei é o que o povo ordena e estabelece', e o povo votava os projetos de lei nos diferentes comícios, o das cúrias e das centúrias, sendo este o mais importante. No começo da República, criou-se o comício da plebe - concilium plebis - cuja deliberação, plebiscitum, só obrigava os plebeus. Posteriormente a Lex Hortênsia, de $287{ }^{a} \mathrm{C}$., as decisões da plebe passaram a ter força de lei para toda a população romana. Nos dias de hoje, as assembléias populares de cantão ou semicantão suíços. Na esfera municipal, encontra-se, em pequeno número, tais como as assembléias populares de comunas suíças, os town meetings das municipalidades menores da região de Nova-Inglaterra, nos Estados Unidos.

Semidireto: o povo coopera com os seus representantes na formação da lei. A legislação resulta, então, de ato complexo, da concordância da vontade do órgão representativo com a vontade do eleitorado. É o que caracteriza o referendum popular, distinguindo-o do plebiscito e da simples consulta popular. 
previsto no $\S 2^{\circ}$ do artigo 223 para a "não renovação da concessão ou permissão" de serviço de radiodifusão sonora e de sons e imagens. Nesse dispositivo, há, ainda, a única exigência, por norma constitucional, de que a votação deva se dar pelo processo nominal.

As Constituições Estaduais adotaram também, mutatis mutandis, os quóruns de deliberação previstos na Federal.

\begin{tabular}{|c|c|c|c|c|c|}
\hline \multicolumn{6}{|c|}{ QUÓRUNS DE DELIBERAÇÃO NAS ASSEMBLÉIAS LEGISLATIVAS } \\
\hline ESTADO & $\mathbf{N}^{\circ}$ DE DEP. & M. ABSOLUTA & M. SIMPLES & $3 / 5$ & $2 / 3$ \\
\hline São Paulo & 94 & 48 & 25 & 57 & 63 \\
\hline Minas Gerais & 77 & 39 & 20 & 47 & 52 \\
\hline Rio de Janeiro & 70 & 36 & 19 & 42 & 47 \\
\hline Bahia & 63 & 32 & 17 & 38 & 42 \\
\hline Rio Grande do Sul & 55 & 28 & 15 & 33 & 37 \\
\hline Paraná & 54 & 28 & 15 & 33 & 36 \\
\hline Pernambuco & 49 & 25 & 13 & 30 & 33 \\
\hline Ceará & 46 & 24 & 13 & 28 & 31 \\
\hline Maranhão & 42 & 22 & 12 & 26 & 28 \\
\hline Pará & 41 & 21 & 11 & 25 & 28 \\
\hline Goiás & 41 & 21 & 11 & 25 & 28 \\
\hline Santa Catarina & 40 & 21 & 11 & 24 & 27 \\
\hline Paraíba & 36 & 19 & 10 & 22 & 24 \\
\hline Espírito Santo & 30 & 16 & 9 & 18 & 20 \\
\hline Piauí & 30 & 16 & 9 & 18 & 20 \\
\hline Alagoas & 27 & 14 & 8 & 17 & 18 \\
\hline Rio Grande do Norte & 24 & 13 & 7 & 15 & 16 \\
\hline Amazonas & 24 & 13 & 7 & 15 & 16 \\
\hline Mato Grosso & 24 & 13 & 7 & 15 & 16 \\
\hline Mato Grosso do Sul & 24 & 13 & 7 & 15 & 16 \\
\hline Sergipe & 24 & 13 & 7 & 15 & 16 \\
\hline Rondônia & 24 & 13 & 7 & 15 & 16 \\
\hline Tocantins & 24 & 13 & 7 & 15 & 16 \\
\hline Acre & 24 & 13 & 7 & 15 & 16 \\
\hline Amapá & 24 & 13 & 7 & 15 & 16 \\
\hline Roraima & 24 & 13 & 7 & 15 & 16 \\
\hline
\end{tabular}

Afirmou-se acima que as Constituições Estaduais adotaram os mesmos quóruns previstos na Constituição Federal. Exceto a Constituição do Estado do Espírito Santo, que estabeleceu o quorum de quatro quintos para aprovação de proposta de emenda à Constituição, elevando-o de 60\% para 80\%. Como relator da ADI n. 486-DF, o Min. Celso de Mello em suas razões de decidir entendeu "assistir plena razão ao eminente Procurador-Geral da República, quando sustenta que, também em sede de reforma constitucional, os Estados-membros estão sujeitos à observância necessária dos padrões normativos fixados pela Carta da República, cujas prescrições impõem, de maneira incontrastável, às unidades federadas regionais, clara subordinação normativa aos postulados que regem o processo de emenda à Constituição. Essa é a razão pela qual o eminente chefe do Ministério Público da União, ao opinar pela procedência da presente ação direta de inconstitucionalidade, acentuou que a jurisprudência do Supremo Tribunal Federal - não obstante a ausência de norma explícita inscrita na 
vigente Constituição da República - consolidou-se no sentido de reconhecer que se aplicam, de maneira subordinante, aos Estados-membros, as diretrizes básicas concernentes ao processo legislativo". Identificou esta limitação como sendo de ordem formal e, junto com a dualidade de turnos seqüenciais de discussão e votação, incidem na esfera procedimental, como "exigência irredutível e inampliável, a maioria de 3/5". E arrematou suas razões argumentando: "Se se reconhecer, ao Estado-membro, a possibilidade de agravar, ainda mais, em tema de reforma constitucional, as condições fixadas pela Carta da República, mesmo em divergência com os padrões superiormente instituídos pelo legislador constituinte originário, tornar-se-á inevitável admitir, então, que qualquer das unidades federadas, a pretexto de exercer a sua autonomia (mesmo que em conflito frontal com o modelo federal), possa esterilizar e neutralizar, por completo, o exercício, pela Assembléia Legislativa local, das funções constituintes decorrentes que lhe foram outorgadas pela Constituição Federal, bastando exigir, para efeito de emenda constitucional, a votação favorável da unanimidade dos membros do Poder Legislativo estadual...!" Ao que o Min. Maurício Corrêa acrescentou: "pertenço à corrente segundo a qual, sobretudo em tema de elaboração de norma constitucional, havendo disposição expressa na Constituição que determine um certo parâmetro, os Estados-membros têm de obedecer a esse princípio. Do contrário, o Poder Legislativo dos Estados se transformaria numa verdadeira balbúrdia, cada um estabelecendo, a seu bel-prazer, regras de quóruns diferenciados do estabelecido pelo modelo federal".

\subsubsection{Objeto da votação - proclamação do resultado - efeitos}

Impende que o objeto da votação esteja definido, delimitado, aclarado e anteriormente anunciado pelo Presidente da sessão. Dela participam apenas os que estiverem no exercício do mandato. Vale dizer, os licenciados (por motivo de saúde ou particular) e os afastados para desempenho de cargos notáveis ${ }^{245}$ ficam impedidos de fazer parte da deliberação.

Vencidas já as anteriores fases de tramitação, para que determinado projeto possa ser submetido a votos, cumpre que já se tenha constatado, na forma regimental, a existência no Plenário do quorum constitucional de deliberação. Sem que tenha havido esta constatação, há impedimento de se proceder à votação. É que, à evidência, para

\footnotetext{
245 Ministro de Estado, Secretário de Estado, Secretário de Prefeitura de Capital ou Chefe de Missão Diplomática temporária (art. 56 , I, c.c. $27, \S 1^{\circ}$, da CF).
} 
que o Presidente da sessão possa enunciar o comando de aprovação ou de rejeição de uma matéria posta a votos, imprescindível que o quorum deliberativo para ela exigido efetivamente exista. Cabe apontar, então, que, para se iniciar uma votação de matéria que não exija quorum qualificado, deve-se constatar, ao menos, a presença da maioria absoluta de parlamentares; e, no mínimo, a presença de $3 / 5$ (três quintos) ou de 2/3 (dois terços) para a votação das matérias que requeiram, respectivamente, esse montante de votos para aprovação. Numa votação simbólica, por exemplo, se uma proposição for enunciada pelo Presidente da sessão como aprovada (ou rejeitada) e não houver oportuno requerimento de verificação de votação - para que o seu resultado se confirme pelo processo nominal -, a proposição será tida por aprovada (ou rejeitada). Há, pois, in casu, presunção de que o quorum de votação da respectiva matéria fora anteriormente observado.

Impende também sublinhar que, mesmo quando enunciado no curso da discussão, o voto só se torna eficaz se proferido no devido momento procedimental regimentalmente previsto para ser acolhido. Assim, extemporâneo e inexistente para efeito de quorum é o voto declarado no curso da discussão da matéria, como também o é aquele que pretende ser consignado por parlamentar após a proclamação do resultado da votação pelo Presidente da sessão.

Como salienta Sepúlveda Pertence, "os Deputados recebem da própria Constituição, como conteúdo do mandato em que são investidos, mais que o direito, a competência para, como órgão parcial da função legislativa, votar". ${ }^{246}$ Após informar o número de parlamentares participantes do processo de votação, o presidente anuncia e proclama o seu resultado. $\mathrm{O}$ ato de proclamação de resultado de votação em órgãos colegiados, como são os do Poder Legislativo (Plenário, Comissões), implica efetivação da vontade do órgão no exercício da função deliberativa que, constitucionalmente, lhe é atribuída. Realizada a votação, cessa a atribuição dos órgãos parciais (cada um dos parlamentares), e o resultado da decisão é imputado, então, ao Poder Legislativo como um todo, ao colegiado, representante do povo, de onde emana o poder político.

A proclamação do resultado da votação é ato privativo de quem a presidiu, competindo-lhe, nessa oportunidade, quando dúvidas houver, a interpretação das normas constitucionais e regimentais acerca do procedimento de votação. E dúvidas

\footnotetext{
${ }^{246}$ Voto de Liderança. In: RDP n. 76, p. 60.
} 
há. Tome-se como hipótese, numa Casa Legislativa com 100 (cem) parlamentares, a votação de uma proposta de emenda à Constituição, cujo quorum de aprovação é 3/5 (três quintos). Supondo-se que, em votação nominal, todos tivessem participado da votação e assim votado: 58 'sim', 20 'não' e 22 registros de ‘abstenção', qual seria o resultado a ser proclamado? Rejeitada a matéria? Votação adiada?

Há Regimentos Internos que disciplinam a questão preceituando: “a votação das proposições, cuja aprovação exija quorum especial, será renovada tantas vezes quantas forem necessárias, no caso de se atingir apenas maioria simples" (art. 196, parágrafo único da XIII Consolidação do Regimento Interno da Alesp). Ou, então, na Câmara Municipal de São Paulo, quando norma regimental estatui: “Art. 287 - ... $3^{\circ}$ - Na votação dos projetos que não atingir o quorum regimental, os mesmos serão considerados pendentes de votação e constarão da Ordem do Dia da próxima sessão. § $4^{\circ}$ - Serão considerados rejeitados: I) os projetos que, necessitando quorum de três quintos para aprovação, tiverem mais de dois quintos de votos contrários; II) os projetos que, necessitando quorum de dois terços para aprovação, tiverem mais de um terço de votos contrários".

No Senado e na Câmara dos Deputados, na ausência de norma regimental sobre a questão, os Presidentes têm reiteradamente decidido que, numa situação como a exemplificada, a proposição seria tida como rejeitada. ${ }^{247}$

Ora, não pode ser negado que as conclusões sobre a proclamação do resultado de votação no âmbito do Congresso Nacional apontam para uma rejeição de matéria sem que ela tenha sido efetivamente rejeitada. $\mathrm{O}$ fato de a proposição não ter alcançado o número necessário para sua aprovação não significa, por si só e contrario sensu, que tenha sido rejeitada. É, sim, por interpretação que se conclui que, levada a votos, caso não se alcance o número de escrutínios necessários para sua aprovação, uma proposição é tida por rejeitada.

Se, em virtude de preceito constitucional, a partir de 1988, aboliu-se da prática legislativa a aprovação tácita por decurso de prazo, ainda não se extinguiu, todavia, a rejeição tácita, verificada quando não se atinge, numa votação, o quorum exigido para aprovação de determinada matéria. Em colegiados, onde se decide por

${ }^{247}$ No Senado, veja-se a votação, em 28 de junho de 2004, da Proposta de Emenda Constitucional n. 353/01 (apensas as de $\mathrm{n}^{\circ} \mathrm{s} 452 / 01$ e 71/03), que dispunha sobre fixação de número de vereadores. Submetida a votos e não obtendo quorum para aprovação (foram 41 favoráveis e 11 contra, quando necessários 49 favoráveis), a matéria foi declarada rejeitada. 
maioria de votos, impende que o resultado proclamado de uma votação seja a exata expressão dos votos, espelhando tão-somente a expressão numérica então obtida, caso contrário somente se estará a exigir o quorum para aprovação. Parece que a disciplina que melhor atende à proclamação do exato resultado de uma votação de um colegiado legislativo assenta-se na premissa de só se dar por rejeitada uma proposição quando ela obtiver: I) mais de 2/5 de votos contrários, quando se exigir 3/5 para aprovação; II) mais de $1 / 3$ de votos contrários, quando se exigir $2 / 3$ para aprovação; e III) maioria relativa de votos contrários, quando presente, ao menos, a maioria absoluta do colegiado.

Quando não se atingir essas necessárias condições e o resultado for tendente à aprovação, vale dizer, se houver relativamente mais votos favoráveis, ficaria a proposição com sua votação adiada para uma próxima deliberação em outra sessão.

Dir-se-á, no entanto, que, ao assim se proceder na proclamação do resultado de uma votação, estar-se-ia contribuindo para a morosidade dos trabalhos legislativos, com possibilidade de infindáveis adiamentos. Pode ser. Contudo, a decisão do colegiado seria sempre fidedigna, não se rejeitando, como se rejeitou e se rejeita, proposta de emenda à Constituição que obtivesse (e obtenha) número de votos tendentes a aprová-la, como ocorreu na votação da "Pec das Diretas-já" - cuja aprovação era aguardada pela maioria do povo brasileiro -, assim conhecida a Proposta de Emenda n. 5, de 1983 e que teve como primeiro signatário o Dep. Dante de Oliveira, votada na $62^{\mathrm{a}}$ sessão conjunta congressual, de 25 de abril de 1984:

"O SR. PRESIDENTE (Moacyr Dalla) - A Mesa vai proclamar o resultado da votação: 298 - "SIM"; 65 - "NÃO"; 3 abstenções.

Os votos, embora majoritários, não alcançaram o quorum constitucional necessários à aprovação da matéria. A proposta está rejeitada.

Rejeitada pela Câmara, deixa a matéria de ser submetida ao Senado Federal.

A proposta vai ao Arquivo."248

A mesma sorte não teve as contas do Executivo da cidade de São Paulo relativas ao exercício de 1990, com parecer prévio do Tribunal de Contas do Município pela sua rejeição. $\mathrm{Na} 135^{\mathrm{a}}$ sessão extraordinária, realizada em 2 de outubro de 1991, posto a votos o parecer do Tribunal de Contas obteve, dos 53 Vereadores que então compunham aquela Câmara Municipal, o seguinte resultado: 7 votos pela aceitação do

\footnotetext{
${ }^{248}$ Diário do Congresso Nacional, edição de 26 de abril de 1984, p. 767.
} 
parecer; trinta e um votos pela rejeição do parecer; quinze Vereadores faltaram. Como eram necessários 36 votos (2/3) para rejeitar o parecer, o Presidente da sessão proclamou: "A matéria ficou pendente de votação". Como fundamento da decisão do presidente, a existência de exata norma regimental (art. 287 supra mencionado) exigindo expressa manifestação da Casa Legislativa em ordem a aprovar ou rejeitar matéria gizada pelo quorum qualificado. ${ }^{249}$

Proclamado o resultado de uma votação, seja da matéria principal (projeto) ou de acessória (emendas), impende que o Presidente declare, quando for o caso, prejudicada(s) outra(s) proposição(ões). É o que dispõem os Regimentos Internos na disciplina "da prejudicabilidade", na terminologia paulista (art. 178) e pernambucana (arts. 199 a 203), ou “da prejudicialidade”, na designação mineira (art. 284). ${ }^{250}$

Decorrente da rejeição, vem a lume no cenário do processo legislativo a autoria coletiva. Com efeito, a matéria constante de projeto de lei rejeitado, diz o preceito constitucional, só poderá ser renovada, na mesma sessão legislativa, mediante outro projeto de autoria conjunta, a (autoria) da maioria (absoluta) dos membros da Assembléia Legislativa. Como a rejeição de qualquer proposição se dá por maioria simples, ${ }^{251}$ desde que presente para votar, no mínimo, maioria absoluta dos membros da Assembléia, é mesmo possível vislumbrar para esta matéria alguma perspectiva de aprovação, já agora tramitando sob o manto protetor da autoria majoritária dos membros da Assembléia, credenciando-a à aprovação, no mínimo, por essa maioria, o que, em termos de quorum deliberativo já seria suficiente. Já a rejeição de matéria constante de proposta de emenda constitucional tem como efeito a

249 A essa decisão do presidente da Câmara Municipal de São Paulo foi impetrado o Mandado de Segurança n. 13.996-0/4 perante o Tribunal de Justiça de São Paulo, com pedido de liminar negado.

O parecer foi novamente incluído na Ordem do Dia da $136^{\mathrm{a}}$ sessão extraordinária, realizada no dia 8 de outubro, com o seguinte resultado: 19 votos pela aceitação do parecer; 41 pela rejeição do parecer; e 9 abstenções.

250 “Art. 284 - Consideram-se prejudicadas:

I - a discussão ou a votação de proposição com objetivo idêntico ao de outra aprovada ou rejeitada na mesma sessão legislativa;

II - a discussão ou a votação de proposição semelhante à outra considerada inconstitucional pelo Plenário;

III - a discussão ou a votação de proposição anexada a outra, quando aprovada ou rejeitada a primeira;

IV - a proposição e as emendas incompatíveis com substitutivo aprovado;

$\mathrm{V}$ - a emenda ou a subemenda de matéria idêntica à de outra aprovada ou rejeitada;

VI - a emenda ou a submenda em sentido contrário ao de outra aprovada;

VII - a emenda ou parte de proposição incompatível com matéria aprovada em votação destacada.”

251 Evidente que, presentes em Plenário um número maior que a maioria absoluta dos membros da Assembléia, a rejeição dar-se-á pela maioria desses votantes, dita, então, maioria relativa. 
imposição de uma condição temporal: a matéria rejeitada somente poderá ser objeto de nova proposta em outra sessão legislativa anual.

\subsubsection{Voto de Liderança}

Em apurado registro acerca de traço essencial do mandato parlamentar, Celso de Mello observa: "O direito de votar traduz prerrogativa constitucional ínsita ao próprio exercício do mandato legislativo. Dentre as muitas atribuições parlamentares, avulta, por sua inquestionável essencialidade, o poder-dever de votar, que incumbe, individualmente, a cada membro do Congresso Nacional." 252

Em ordem a acentuar o caráter pessoal do voto nas Casas Legislativas, o constituinte de 1988 prevê sanção com a perda do mandato, se o parlamentar não comparecer a um terço das sessões legislativas ordinárias e extraordinárias realizadas no Plenário (art. 55, III, da CF). E, como norma de preordenação dos Estadosmembros, a Constituição Federal determina a aplicação aos Deputados Estaduais das regras sobre perda de mandato nela definidas (art. 27, § $1^{\circ}$ ). A imprescindível presença do parlamentar perpassa o funcionamento das Casas Legislativas. No entanto, necessário se fez até a sanção com perda do mandato, desde a Constituição de 1934 (art. 34), para coibir a prática absenteísta parlamentar.

Frise-se. A singular metodologia de trabalho das Casas Legislativas aponta para a esfera pública no momento decisional. Tércio Sampaio Ferraz Jr. fundadamente observa que decidir publicamente faz parte da metodologia de trabalho do Legislativo. $^{253}$ Nele, há uma peculiar separação entre os momentos de produção e a encenação das decisões para consecução das funções precípuas do Poder Legislativo. "As decisões podem ser tomadas em reuniões de gabinete, em comissões técnicas, mas a encenação da tomada de decisão é pública". 254 É pública e exige participação individual dos que foram eleitos como representantes do povo no Legislativo. Investido no mandato pelo voto do povo, o parlamentar passa a exprimir, pelo voto nas Casas Legislativas, uma vontade soberana que juridicamente fora imputada àquele. Age em nome alheio, sendo-lhe proibido delegar a outrem o seu exercício, que é a própria

\footnotetext{
${ }^{252}$ MELlO FILHO, José Celso. Constituição Federal anotada. São Paulo: Saraiva, 1986, p. 154.

253 A Constituição do Estado de São Paulo, promulgada em 05 de outubro de 1989, não admite sessões reservadas ou secretas e preceitua:

“Art. 10 - A Assembléia Legislativa funcionará em sessões públicas, presente, pelo menos, um quarto de seus membros."

${ }^{254}$ FERRAZ JR., Tércio Sampaio. Democracia..., ob. cit., p. 63.
} 
essência do mandato representativo, podendo-se, por isso mesmo, fazer-se referência à característica de indelegabilidade do mandato e, pois, do próprio do voto parlamentar.

O quorum constitucional para decisão, previsto no art. 47 da Constituição Federal como regra de deliberação por maioria, está também inserto em todas as Constituições Estaduais: "Salvo disposição constitucional em contrário, as deliberações de cada Casa e de suas Comissões serão tomadas por maioria dos votos, presente a maioria absoluta de seus membros".

No entanto, acerca dos processos de votação, o Regimento Interno da Assembléia Legislativa do Estado de Rondônia, aprovado pela Resolução n. 32, de 21 de agosto de 1990, e alterado pela Resolução n. 126, de 18 de outubro de 2006, faz tabula rasa da efetiva presença parlamentar no Plenário, presumindo-a tão-só, ao dispor no artigo 218:

"Pelo processo simbólico, o Presidente, ao anunciar a votação de qualquer matéria, convidará os Deputados a favor a permanecerem sentados, e proclamará o resultado manifesto dos votos. A manifestação dos Líderes representará o voto de seus liderados, permitida a declaração de voto."

Também no Regimento Comum do Congresso Nacional ${ }^{255}$ encontram-se ainda positivados preceitos sobre o exercício do voto de Liderança:

\footnotetext{
${ }^{255}$ Regimento Comum: Resolução n. 1, de 1970-CN, com alterações posteriores, até 2006, e legislação conexa. Brasília: Congresso Nacional, 2007, p. 27.

Nota: "O Regimento Comum do Congresso Nacional foi originalmente aprovado pela Resolução $\mathrm{n}$. 1, de 1970-CN. Parte de seus dispositivos foi revogada ou alterada pela Constituição Federal de 1988 e por Resoluções subseqüentes, razão pela qual, em dezembro de 1994, a Secretaria-Geral da Mesa do Senado Federal preparou uma edição adaptando o Regimento Comum àquelas modificações.

Ao final da $51^{\text {a }}$ Legislatura, em janeiro de 2003, a Mesa do Congresso Nacional, valendo-se do disposto no art. 151 do Regimento Comum, aplicou subsidiariamente o art. 402 do Regimento Interno do Senado Federal e publicou o texto do Regimento Comum, consolidado em relação ao referido texto editado em 1994, introduzindo as modificações decorrentes das Resoluções nº 3 3, de 1989-CN; 1 , de $1995-\mathrm{CN}$; e 1 e 2 , de $200-\mathrm{CN}$.

Além disso, na mencionada consolidação foram observadas as regras contidas na Lei Complementar n. 95, de 1998, que dispõe sobre a elaboração, a redação, a alteração e a consolidação das leis, conforme determina o parágrafo único do art. 59 da Constituição Federal, e estabelece normas para a consolidação dos atos normativos que menciona, bem como na Lei Complementar n. 107, de 2001, que a alterou.

Agora, ao final da $52^{\mathrm{a}}$ Legislatura, a Mesa do Congresso Nacional faz publicar o texto do Regimento Comum nos termos daquele editado em 13 de janeiro de 2003, uma vez que ele não sofreu alterações nos últimos quatro anos."
} 
"Art. 45 - Na votação pelo processo simbólico, os Congressistas que aprovarem a matéria deverão permanecer sentados, levantando-se os que votarem pela rejeição. $O$ pronunciamento dos Líderes representará o voto de seus liderados presentes, permitida a declaração de voto."

Em parecer sobre o voto de liderança, previsto no artigo 176 do Regimento Interno da Câmara dos Deputados, onde Deputado federal impetrara Mandado de Segurança contra o presidente da Câmara, visando a que se lhe assegurasse o direito de voto, sempre que presente às sessões da Casa, o então Procurador Geral da República, José Paulo Sepúlveda Pertence observava, em 2 de setembro de 1985:

“(...) é inegável que o voto de liderança é um instrumento de excepcional eficácia para vencer o problema do absenteísmo nas sessões plenárias do Legislativo. Como o problema não é novo, nem é brasileiro, mas, ao contrário, de há muito preocupa parlamentos de todo o mundo, a repulsa ao mecanismo estabelecido entre nós constitui um indício eloqüente da sua incompatibilidade com os princípios cardeais, que regem o instituto do mandato legislativo." 256

O contundente parecer de Sepúlveda Pertence, em época de transição do regime militar autoritário para o democrático, acentuava que o voto de liderança, o decreto-lei, o decurso de prazo e a fidelidade partidária esvaziavam "o conteúdo real do mandato legislativo". Destes instrumentos citados, o que mais "castrava, de modo mais fundo, a plenitude do mandato parlamentar", era o voto de liderança, paradoxalmente regrado por norma regimental, de exclusiva atribuição do Legislativo. Argumentava, então:

"De fato. O decreto-lei pode ser rejeitado. E o 'decurso de prazo' não resiste à força da decisão da maioria absoluta da Câmara, bastante, não apenas para rejeitar o projeto ou o decreto-lei, mas também para vencer a obstrução, pela ausência, da minoria favorável à aprovação. Já o instituto do voto de liderança faz, dos Líderes, mandatários dos seus liderados, independentemente ou mesmo contra a vontade deles. Tanto que nem a presença do Deputado na sessão e a sua manifestação contrária ao voto do Líder impedirão que este tenha o peso do número total da bancada partidária. Desse modo, o voto de liderança, sob certa perspectiva, supera até o extinto mecanismo da fidelidade partidária [nova redação dos arts. 35 e 152 da CF, cf. EC 25/85]. Neste, com efeito, em primeiro lugar, o 'fechamento de questão' era objeto de decisão formal de órgãos amplamente representativos da vontade partidária (a Convenção ou o Diretório Nacional), sujeita, ainda, ao controle de

${ }^{256} R D P$ n. 76, p. 60. 
legalidade da Justiça Eleitoral. De outro modo, como bem sabido, a inobservância da diretriz partidária não anulava nem o voto contrário, nem a abstenção do parlamentar dissidente, ainda que pudesse sujeitálo, mediante o due process of law, à sanção extrema da perda do mandato. Este, porém - aqui está o ponto - enquanto durasse, poderia ser exercido com plenitude. Já no sistema do voto de liderança, a oposição à vontade pessoal do Líder, é certo, não põe em risco o mandato do dissidente, mas, por outro lado, o esvazia de sua prerrogativa fundamental, o exercício do voto em contrário.”257

À essencial característica da indelegabilidade do voto, pois personalíssimo o exercício do mandato parlamentar, ${ }^{258}$ Sepúlveda Pertence acentuava que o "o voto de liderança importa na criação, por força de norma regimental, de uma representação sem mandato: o Líder representa todos os Deputados do seu Partido, independentemente da vontade deles, desnecessária para constituir o mandatário e - o que é mais assustador - impotente para destituí-lo, no caso concreto, do poder de voto plural". Acentuava mais, e são considerações válidas também para a ordem constitucional em vigor, que "os Deputados recebem da própria Constituição, como conteúdo do mandato em que são investidos, mais que o direito, a competência para, como órgão parcial da função legislativa, votar". ${ }^{259}$ E delegar essa essencial atribuição, como ainda faz o legislador regimental rondoniense e o congressual, fere de morte o mandato parlamentar livre. Máxime porque: a) há norma constitucional expressa exigindo presença de maioria absoluta dos membros da Casa Legislativa como condição deliberativa (art. 47); b) a ausência às sessões plenárias é punida com a perda do mandato parlamentar (art. 55, III, c.c. art. $27, \S 1^{\text {o }}$; c ) e também em razão de não mais vir expressa norma constitucional de conteúdo conformador da aprovação por decurso de prazo.

Mais. Nada obstante decisão do Tribunal Superior Eleitoral, confirmada pelo Supremo Tribunal Federal sobre fidelidade partidária, entendendo ser do Partido Político o mandato parlamentar ${ }^{260}$; muito embora também o fechamento de questão no

\footnotetext{
${ }^{257}$ Idem, p. 59-60.

258 Em sentido contrário: FALCÃO, Alcino Pinto. Voto de Liderança como sub genus do voto por procuração. Revista de Direito Constitucional e Ciência Política. Rio de Janeiro: Forense: Instituto Brasileiro de Direito Constitucional, n. 6, jan., 1988, p. 236-256.

${ }^{259} R D P$ n. 76 , p. 61.

${ }^{260}$ Informativo STF n.528. ADI 3999. "O Tribunal, por maioria, julgou improcedente pedido formulado em duas ações diretas de inconstitucionalidade, a primeira ajuizada contra a Resolução 22.610/2007, pelo Partido Social Cristão - PSC, e a segunda, também contra a Resolução 22.733/2008, pelo Procurador-Geral da República, ambas do Tribunal Superior Eleitoral - TSE, as quais disciplinam o processo de perda de cargo eletivo em decorrência de desfiliação partidária sem justa causa, bem como de justificação de desfiliação partidária.
} 
âmbito de um Partido sobre como deve ser o voto dos seus parlamentares nas Casas Legislativas sobre determinada matéria (art. 17, § $1^{\circ}$, da CF); não obstante inexistir mandamento expresso na Constituição Federal consagrando o mandato parlamentar no Brasil como sendo um mandato livre, jamais imperativo, como há na Constituição da França: "Todo mandato imperativo é nulo.” (art. 27); da Espanha, que preceitua que os membros das Cortes Gerais não estão vinculados a mandato imperativo (artigo 67.2); da Alemanha, que estatui que os membros do Parlamento Federal Alemão "serão representantes do povo como um todo, não estando sujeitos a ordens ou instruções, mas apenas à sua consciência" (artigo 38.1). E, mesmo havendo orientação do Líder do Partido na Casa Legislativa sobre como devem votar os liderados acerca de determinada matéria; mesmo assim, em Regimentos Internos que não prevêem o voto de liderança nas Assembléias Legislativas, e são a quase totalidade, há norma garantidora do exercício do mandato parlamentar, presumindo-o livre, jamais imperativo: "O voto da Deputada ou do Deputado, mesmo que contrarie o da respectiva representação ou sua Liderança, será acolhido para todos os efeitos"261 .

O constituinte gaúcho, por sua vez, espancando qualquer dúvida, assentou, de forma expressa, características do voto parlamentar: "Art. 51 - As deliberações da Assembléia Legislativa, salvo disposição em contrário nesta Constituição, serão tomadas por maioria de votos, individuais e intransferíveis, presente a maioria de seus membros".

O voto de liderança, por implicar delegação indevida do poder-dever de votar conferido a cada parlamentar individualmente, subtrai atribuição essencial do

Preliminarmente, o Tribunal, por maioria, conheceu das ações. Vencido, no ponto, o Min. Marco Aurélio que delas não conhecia por reputar não se estar diante de atos normativos abstratos e autônomos. No mérito, julgaram-se válidas as resoluções impugnadas até que o Congresso Nacional disponha sobre a matéria. Considerou-se a orientação fixada pelo Supremo no julgamento dos mandados de segurança 26602/DF (DJE de 17.10.2008), 26603/DF (j. em 4.10.2007) e 26604/DF (DJE de 3.10.2008), no sentido de reconhecer aos partidos políticos o direito de postular o respeito ao princípio da fidelidade partidária perante o Judiciário, e de, a fim de conferir-lhes um meio processual para assegurar concretamente as conseqüiências decorrentes de eventual desrespeito ao referido princípio, declarar a competência do TSE para dispor sobre a matéria durante o silêncio do Legislativo. Asseverou-se que de pouco adiantaria a Corte admitir a existência de um dever, qual seja, a fidelidade partidária, mas não colocar à disposição um mecanismo ou um instrumental legal para garantir sua observância. Salientando que a ausência do mecanismo leva a quadro de exceção, interpretou-se a adequação das resoluções atacadas ao art. 23, IX, do Código Eleitoral, este interpretado conforme a CF. Concluiu-se que a atividade normativa do TSE recebeu seu amparo da extraordinária circunstância de o Supremo ter reconhecido a fidelidade partidária como requisito para permanência em cargo eletivo e a ausência expressa de mecanismo destinado a assegurá-lo. Vencidos os Ministros Marco Aurélio e Eros Grau, que julgavam procedente o pleito, ao fundamento de que as citadas resoluções seriam inconstitucionais, haja vista não caber ao TSE dispor normas senão tendo em vista a execução do Código Eleitoral e da legislação eleitoral, que não trataram da perda de cargo eletivo em razão de infidelidade partidária, e, ainda, porque avançam sobre áreas normativas expressamente atribuídas, pela Constituição, à lei. ADI 3999/DF, rel. Min. Joaquim Barbosa, 12.11.2008."

${ }^{261}$ XIII Consolidação do Regimento Interno da Assembléia Legislativa de São Paulo, art. 199, § 4º 
mandato parlamentar. O voto parlamentar plural dá supedâneo ao mandato parlamentar imperativo, inadmitido pelo constituinte brasileiro, que o pressupõe livre: "Os Deputados e Senadores são invioláveis, civil e penalmente, por quaisquer de suas opiniões, palavras e votos" (art. 53, caput, da CF). E esse preceito aplica-se, ex vi do art. $27, \S 1^{\circ}$, da Constituição Federal, aos Deputados Estaduais. Imperioso, pois, sejam expungidos, tanto do Regimento Interno da Assembléia Legislativa de Rondônia como do Regimento Comum do Congresso Nacional os dispositivos que prevêem o voto de liderança.

\subsubsection{Decurso de prazo}

O decurso de prazo está associado à concepção chanceladora do Legislativo, homologador de proposituras de iniciativa do Executivo mediante presunção de deliberação parlamentar, depois de decorrido certo prazo de tramitação no processo legislativo. Prevaleceu na ordem constitucional imediatamente anterior e soava como ranço autoritário a ser extirpado do processo legislativo pelo constituinte de 1988, designadamente porque, ao impingir ao Parlamento prazo certo para deliberação de proposição, concedia ao Executivo direito de imiscuir-se na agenda legislativa, bem como a possibilidade de, controlando a atuação dos parlamentares de sua base de sustentação, conduzir um processo de obstrução que podia resultar em aprovação tácita de proposições de sua iniciativa.

\section{Substituído pela inclusão automática na Ordem do Dia até final} deliberação de proposição de iniciativa do Executivo, o decurso de prazo estaria banido do processo legislativo, inclusive do processo legislativo estadual, vez que evitar sua consecução erigiu-se em princípio de observância obrigatória, inclusive para os Estados-membros. É, outrossim, a conclusão de Manoel Gonçalves Ferreira Filho: “(...) se poderia ver como 'princípio' a necessidade de deliberação da Assembléia Legislativa sobre os projetos de lei". ${ }^{262}$

No entanto, essa técnica de deliberação pelo silêncio longe está de ter sido abolida do processo legislativo previsto na Constituição Federal e nas Constituições Estaduais. Tome-se o disposto no artigo 66 , $\S 3^{\circ}$, da Constituição Federal, que, de resto, foi acompanhado pelas vinte e seis Constituições Estaduais: "decorrido o prazo de quinze dias, o silêncio do Presidente da República importará sanção". Dir-se-á que aí se concedeu ao Executivo a deliberação ficta. No entanto, o silêncio do Legislativo

\footnotetext{
${ }^{262}$ Do Processo Legislativo, 6. ed., São Paulo: Saraiva, 2007, p. 255.
} 
também já aprovou centenas de medidas provisórias editadas em data anterior à da publicação da Emenda Constitucional n. 32, de 11 de setembro de 2001, vez que todas elas "continuam em vigor até que medida provisória ulterior as revogue explicitamente ou até deliberação definitiva do Congresso Nacional" (art. $2^{\circ}$ da EC n. 32). O silêncio do Legislativo prorroga, também, a vigência de medida provisória (art. 62, § $7^{\circ}$ ); bem assim, a omissão do Legislativo, ao não editar decreto legislativo após a rejeição ou perda de eficácia de medida provisória, também conserva as relações jurídicas constituídas e decorrentes de atos praticados durante a vigência da medida provisória (art. 62, § 11).

O silêncio, como técnica de deliberação, está igualmente previsto em procedimentos legislativos estaduais. ${ }^{263}$ Não apenas, em moldes correlatos a esses, nos Estados que adotam a medida provisória, como é o caso do Acre (art. 52, IV e V), Maranhão (art. 40, IV), Paraíba (art. 61, IV e V), Piauí (art. 74, IV, acrescido pela EC de revisão n. 1/94), Santa Catarina (art. 48, V e VI) e Tocantins (art. 25, IV e V), mas também em preceitos regimentais ou legais esparsos.

Anote-se, e.g., o estatuído na Lei Complementar paulista n. 918, de 11 de abril de 2002:

"Artigo $1^{\circ}$ - Os membros do Conselho Diretor da Agência Reguladora de Serviços Públicos Delegados de Transporte do Estado de São Paulo - ARTESP, serão nomeados pelo Governador do Estado

263 Pode-se também acrescentar ao rol de matérias aprovadas pelo silêncio, a anuência tácita dos Executivos Estaduais, prevista no art. $4^{\circ}$ da Lei Complementar federal n. 24, de 1975, cuja vigência e validade, após o advento da nova ordem constitucional, em 1988, são reconhecidas em vários julgados do Supremo Tribunal Federal (ADI-MC n. 3.389/RJ; ADI n. 1.179/SP; ADI n. 2.439/MS). Trata-se de lei editada com a finalidade de evitar a hoje denominada 'guerra fiscal' entre os Estados, vez que, por convênios celebrados entre os Estados e aprovados pela unanimidade dos representantes das Unidades federadas no Conselho Nacional de Política Fazendária - CONFAZ, faculta-se, e.g., adotar medidas atinentes a isenção ou redução do ICMS. Esses convênios têm sido aprovados por decreto do Executivo, não obstante o preceituado no $\S 6^{\circ}$ do art. 150 da Constituição Federal, que exige lei estadual stricto sensu. Transcreve-se:

"Art. $4^{\circ}$ - Dentro do prazo de 15 dias contados da publicação dos convênios no Diário Oficial da União, e independentemente de qualquer outra comunicação, o Poder Executivo de cada Unidade da Federação publicará decreto ratificando, ou não, os convênios celebrados, considerando-se ratificação tácita dos convênios a falta de manifestação no prazo assinalado neste artigo.

$\S 1^{\circ}$ - O disposto neste artigo aplica-se também às Unidades da Federação cujos representantes não tenham comparecido à reunião em que hajam sido celebrados os convênios.

$\S 2^{\circ}$ - Considerar-se-á rejeitado o convênio que não for expressa ou tacitamente ratificado pelo Poder Executivo de todas as Unidades da Federação ou, nos casos de revogação a que se refere o art. $2^{\mathrm{a}}, \S 2^{\circ}$, desta lei, pelo Poder Executivo de, no mínimo, quatro quintos das Unidades da Federação". 
e submetidos à aprovação do Plenário da Assembléia legislativa após argüição pública pela Comissão de Transportes e Comunicações, em reunião extraordinária, convocada para esse fim.

$\S 1^{\circ}$ - A Assembléia Legislativa deliberará em 30 dias, após os quais as nomeações serão consideradas aprovadas."

Fazendo uso da mesma técnica de aprovação ficta, a Lei Complementar paulista n. 1025, de 7 de dezembro de 2007, dispondo sobre os diretores da Agência Reguladora de Saneamento e Energia - ARSESP, preconiza que as nomeações efetuadas pelo Governador serão consideradas aprovadas, se a Assembléia Legislativa não deliberar em 30 dias (art. 16, § $7^{\circ}$ ).

O Regimento Interno da Assembléia Legislativa da Paraíba prevê, expressamente, que "será considerada definitivamente aprovada, sem votação", a redação final de proposição, após ter ela figurado em Ordem do Dia sem receber emenda (art. 155, $\S 5^{\circ}$ ). Da mesma forma, o Regimento Interno da Assembléia Legislativa de São Paulo considera aprovada a redação final proposta pela Comissão de Redação que, depois de publicada, não receba emenda para evitar incorreção de linguagem, incoerência notória, contradição evidente ou absurdo manifesto (art. 151, § $3^{\circ}$ e art. 218).

Regimento Interno da Assembléia Legislativa rio-grandense-do-sul, ao disciplinar a apreciação por aquela Casa Legislativa dos convênios e acordos em que o Estado do Rio Grande do Sul seja parte, estipulou prazo de 30 dias para sua apreciação; no entanto, dispôs que "não deliberados no prazo estabelecido ... serão arquivados, após publicados no Diário da Assembléia para conhecimento". Ou seja, os acordos e convênios ficam tacitamente aprovados, bastando tão-só o seu mero conhecimento pela Assembléia. Mais, determinou também que "os convênios e acordos que estiverem tramitando há mais de 30 dias na Assembléia serão arquivados ao final da sessão legislativa, sendo previamente publicados no Diário da Assembléia para conhecimento" (art. 218).

No procedimento legislativo abreviado, as Comissões, em sede deliberante, atuam por delegação do Plenário. Por ele, as Comissões discutem e votam projetos de lei que dispensarem, na forma do Regimento Interno, a competência do Plenário, salvo se houver, para decisão deste, requerimento de um décimo dos membros da Assembléia Legislativa. No procedimento legislativo abreviado, o prazo concedido pelo legislador regimental para que um décimo dos membros da Assembléia requeira, ou não, a 
deliberação final do Plenário, serve também para confirmar aprovação ou rejeição tácita do projeto pelo Plenário. Isto é, a delegação de competência do Plenário da Assembléia à Comissão de mérito para que esta exerça, em nome daquele, a função deliberativa do Legislativo, pode ser suspensa, desde que haja, no prazo fixado pelo legislador regimental, o pedido de um décimo dos membros da Assembléia. Inexistente o requerimento, presume-se conclusiva a deliberação da Comissão de mérito e, pois, aprovado ou rejeitado o projeto, na forma do decidido pela Comissão.

Com presunção diversa, isto é, de rejeição, mas utilizando-se também da deliberação decorrente do silêncio, o constituinte cearense de 1989 buscou manter o decurso de prazo, todavia para rejeição ficta de um projeto de lei. Preceituou, após quarenta e cinco dias de tramitação, inclusão automática em Ordem do Dia de projeto de iniciativa do governador com solicitação de urgência e estipulou que, após quarenta e cinco dias do pedido de urgência e após mais dez sessões consecutivas de inclusão na Ordem do Dia do projeto, se, ainda assim, ele não tivesse sido deliberado, seria, então, considerado "definitivamente rejeitado" (art. 63, § 2º da Constituição Estadual do Ceará). Sobre a matéria, embora tenha havido ação direta de inconstitucionalidade, não há, ainda, decisão definitiva do Supremo Tribunal Federal. ${ }^{264}$

Esses exemplos demonstram que ainda há utilização do decurso de prazo em normas do processo legislativo. Denotam, outrossim, (e isto não é novidade) que há delongas em deliberações do Legislativo e que se busca dar a essa morosidade alguma conseqüência, impulsionando-se procedimento inverso para que não ocorram nem a demora e nem o silêncio deliberativo das Casas Legislativas. Entretanto, há que se ponderar que a falta de celeridade pode também servir, às vezes, para se aprofundar pesquisas, informações, debates e discussões sobre tema polêmico e controverso inserto em propositura legislativa e que exija cautela e precaução redobradas antes de decisão final parlamentar. Sem dizer que, às vezes, o melhor a se fazer em termos de legislar é nada se fazer.

\footnotetext{
264 ADI 143-4. Rel. Min. Celso de Mello. Decisão monocrática final: "Tendo em vista reiterada omissão do autor da presente ação direta, que se absteve - não obstante formalmente intimado - de subsidiar esta Corte com a prestação de informações relevantes ao prosseguimento da causa, julgo-a extinta, com a conseqüente cassação das medidas cautelares anteriormente deferidas (fls. 238/256 e fls. 257/264)."
} 


\subsection{O respeito à Minoria e a questão dos limites da obstrução}

Obstrução parlamentar diz respeito à tática de impedir, delongar, obstruir os trabalhos legislativos mediante utilização de normas procedimentais já expressa ou implicitamente previstas, não se confundindo com conduta vedada a parlamentar, esta sim caracterizadora de violação a disposições de Regimento Interno ou Código de Ética e Decoro Parlamentar, e ensejadora de sanção disciplinar. O escopo principal da obstrução consiste em evitar ou procrastinar deliberações do Poder Legislativo acerca de determinada matéria.

Porque informada pela relatividade do ponto de vista pelo qual pode ser vista, a obstrução pode ser tanto da minoria como da maioria parlamentar, contudo, à evidência, soa mais natural quando efetivada por aquela. Com efeito, a obstrução parlamentar é direito que encontra na democracia condição para prosperar, porque em regimes democráticos não se prescinde de minorias parlamentares, assegurando-se a elas garantias na participação do processo legislativo. No entanto, em cenários autoritários com imposição das normas do processo legislativo, mas que consentem na existência do mandato representativo parlamentar, o expediente obstrucionista, da mesma forma, também alcança ambiente para medrar. Isso decorre da concepção atribuída ao processo legislativo que, como salienta Raul Machado Horta, "não existe autonomamente, como valor em si, pois é técnica a serviço de concepções políticas, realizando fins do poder". ${ }^{265}$ Como técnica a serviço de atuação parlamentar para consecução de fins políticos, o processo legislativo pode ser utilizado como instrumento de operacionalização em ordem a atingir os objetivos políticos desejados tanto pela maioria como pela minoria parlamentar, e ambas dele farão uso para se atingir diferentes desideratos.

Acompanhando, ainda, a análise de Raul Machado Horta, o processo legislativo como técnica a serviço de concepções políticas sofre variadas leituras.

"Daí sua mutabilidade no tempo e sua compreensão variada, refletindo a organização social, as formas de Governo e de Estado, a estrutura partidária e o sistema político. As relações entre o Executivo e o Legislativo podem ser substancialmente alteradas pelo número e a disciplina dos partidos políticos, com reflexos inevitáveis na fixação do processo legislativo correspondente. Assim, quando o Executivo e o Legislativo não passam de dois setores entregues à atividade de um só partido, ou de um partido majoritário e dominante, as relações de poder

${ }^{265}$ Direito constitucional. 3. ed. Belo Horizonte: Del Rey, 2002, p. 519. 
são relações de partido, e o processo legislativo exibirá alto índice de automatismo. As regras normativas do processo legislativo desempenharão, neste caso, uma função secundária, pois as relações políticas se encarregam de estabelecer adequado ajustamento entre vontade governamental e vontade legislativa. Mas, se as relações entre Executivo e Legislativo se ressentem da ausência de partido majoritário, por força de difusa concorrência partidária, as relações entre Executivo e Legislativo serão movediças e muitas vezes críticas, e o processo legislativo se tornará polêmico e contraditório, reclamando desenvolvidas normas de composição de conflitos.",266

Embora tenha se acentuado a tendência de constitucionalização de normas regimentais do processo legislativo, é ainda nos Regimentos Internos que se concentra a autonormatividade das Casas Legislativas para disciplina dos procedimentos legislativos; então, nos Regimentos Internos, designadamente, é que se hão de buscar as formas mais eficazes de atuação parlamentar obstrucionista. Enquanto alguns Regimentos Internos de Assembléias Legislativas são pródigos em oferecer opções para obstrução parlamentar, outros dificultam-na. Tome-se a mais usual das práticas obstrucionistas: prolongar ao máximo a discussão para se evitar votação de determinada matéria. O Regimento da Assembléia Legislativa do Estado de São Paulo, em sua XII Consolidação, que vigorou até novembro de 2007, por exemplo, garantia a cada parlamentar inscrito (93 Deputados, exceto o presidente) para discutir uma propositura, em regime ordinário de tramitação, o tempo de sessenta minutos. $\mathrm{O}$ encerramento da discussão dar-se-ia pela ausência de oradores inscritos ou, após vinte e quatro horas de discussão, mediante requerimento de encerramento, formulado por um terço dos parlamentares, e devidamente aprovado pelo Plenário. Caso o Plenário rejeitasse o encerramento da discussão, ela prolongar-se-ia até que não mais houvesse oradores inscritos. Nas proposições em regime de urgência, o tempo garantido a cada parlamentar inscrito era de trinta minutos, com possibilidade de encerramento, mediante requerimento, após doze horas de discussão. Como o tempo destinado à Ordem do Dia das sessões era de cento e vinte minutos, prorrogáveis, e como qualquer parlamentar podia requerer verificação de presença, caso não houvesse no Plenário, no mínimo, um quarto dos membros da Assembléia (24 Deputados), interrompendo-se a contagem do tempo, a demora na deliberação, caso houvesse obstrução, era garantida. A partir de 13 de novembro de 2007, com a entrada em vigor da XIII Consolidação do Regimento Interno, os prazos foram diminuídos pela metade. Pode-se dizer que houve,

\footnotetext{
${ }^{266}$ Idem.
} 
in casu, na expressão de Mirkine-Guetzévitch, ${ }^{267}$ certa racionalização dos trabalhos legislativos.

No entanto, é de se registrar, igualmente, que o processo obstrucionista pode aprofundar as necessárias condições democráticas de que deve se revestir a elaboração legislativa. Jean Rivero salienta que "o fenômeno majoritário modificou profundamente a fisionomia do teatro político, aproximando o Legislativo do Executivo. Eis por que o valor liberal da lei já não repousa tanto, hoje, sobre o seu órgão de elaboração quanto sobre seu processo de elaboração. É ele, com efeito, que fornece aos cidadãos a garantia de que suas liberdades não serão arbitrariamente sacrificadas". ${ }^{268}$ Por isso mesmo, a lei deve ser "votada ao cabo de um debate público e contraditório, que permita a todas as tendências, até às mais minoritárias, se expressem, e de um processo lento". Acentua, ainda, o autor que "a lei não pode, durante sua gestação, escapar ao controle da opinião pública". ${ }^{269}$ Enfatiza, enfim, e isso pode ser decorrência de postura obstrucionista da minoria parlamentar, que a lei "se não elaborada, pelo menos [deve ser] discutida em praça pública, ela não pode perpetrar um atentado contra uma liberdade "de surpresa", E arremata: "a morosidade que caracteriza sua adoção protege a liberdade: previne as medidas brutais adotadas sob o efeito da emoção nascida de uma crise, impondo ao legislador certo recuo com relação ao acontecimento". ${ }^{270}$

Há Regimentos Internos que restringem, sobremaneira, essa tática parlamentar de obstrução, vez que reduzidíssimo o tempo destinado à discussão, possibilitando somente a alguns parlamentares o direito de usar da palavra para debater a matéria, desprestigiando assim o que assinalou Jeremy Bentham como "a máxima da igualdade: assegurar a todos os membros a faculdade de serem ouvidos". ${ }^{271}$ Sobre os prazos de discussão fixados nos Regimentos Internos das Assembléias Legislativas, confira-se o item 7.6.1 supra.

Por outro lado, há norma constitucional com a finalidade de assegurar ao próprio Legislativo a garantia de tramitação de um projeto de lei por um prazo mínimo razoável. É o que informa o artigo 65 da Constituição rio-grandense-do-sul: "A

\footnotetext{
${ }^{267}$ As novas tendências do direito constitucional. São Paulo: Cia. Editora Nacional, 1933, p. 55-65.

${ }^{268}$ RIVERO, Jean; MOUTOUH, Hugues. Liberdades públicas. Trad. Maria Ermantina de Almeida Prado Galvão. São Paulo: Martins Fontes, 2006, p. 149.

${ }^{269}$ Idem, p. 149.

${ }^{270}$ Id., ib.

${ }^{271}$ BENTHAM, Jeremy. Tácticas Parlamentarias. Ciudad de México: Cámara de Diputados, 2002, p. 183.
} 
Assembléia Legislativa, mediante requerimento subscrito pela maioria de seus membros, pode retirar da ordem do dia, em caso de convocação extraordinária, projeto de lei que não tenha tramitado no Poder Legislativo por, no mínimo, trinta dias”.

O Regimento Interno da Assembléia Legislativa do Estado de São Paulo considera "obstrução parlamentar legítima" a ausência às votações, desde que aprovada pelas Bancadas ou suas Lideranças e comunicada à Mesa na respectiva sessão (arts. 90, $\S 1^{\text {o }}$, item $1 ; 117, \S 4^{\text {o }} ; 90$; e $199, \S 3^{\circ}$ ). À evidência, o parlamentar que não registrou, até então, presença na sessão não fica abrigado pelo manto da presunção regimental de ser considerado presente em votação, caso sua Bancada venha a se declarar 'em obstrução'.

\subsection{Sobrestamento das deliberações de proposições na Ordem do Dia}

Frise-se, mais uma vez, que a Constituição Federal anterior erigia o processo legislativo federal como um dos princípios de observância obrigatória pelos Estadosmembros (art. 13, III). Exsurgia daí a compulsoriedade da previsão dos seguintes dispositivos nas Constituições Estaduais de 1967/69, como na Constituição paulista, por exemplo:

"Artigo 24 - O Governador poderá enviar à Assembléia projetos de lei sobre qualquer matéria, os quais, se o solicitar, deverão ser apreciados dentro de 90 dias a contar do seu recebimento.

$\S 1^{\circ}$ - Se o Governador julgar urgente a medida, poderá solicitar que a apreciação do projeto se faça em 40 dias.

$\S 3^{\circ}$ - Na falta de deliberação dentro dos prazos estabelecidos neste artigo e nos parágrafos anteriores, cada projeto será incluído automaticamente na ordem do dia, em regime de urgência, nas 10 sessões subseqüentes em dias sucessivos; se, ao final dessas, não for apreciado, considerar-se-á definitivamente aprovado."

“Artigo $26-$

$\S 3^{\circ}$ - A apreciação do veto pelo Plenário deverá ser feita dentro de 45 dias de seu recebimento, em uma só discussão, considerando-se aprovada a matéria vetada se obtiver o voto favorável de $2 / 3$ (dois terços) dos membros da Assembléia.

$\S 5^{\circ}$ - Se o veto não for apreciado no prazo do $\$ 3^{\circ}$, considerar-seá acolhido pelo Assembléia." 
Assim estatuído, o decurso de prazo, de observância obrigatória pelos Estados-membros, ex vi do disposto no artigo 13, inciso III, da Constituição de 1967, com a redação dada pela Emenda Constitucional n. 1, de 1969, fazia tabula rasa do voto parlamentar.

A atual Constituição Federal, ensaiando um modelo federativo com maior autonomia para os Estados-membros, não enunciou expressamente para os Estados federados um rol de princípios de observância obrigatória, como, por exemplo, o do processo legislativo; além do que, aboliu o decurso de prazo, num forte indicativo em ordem a resgatar função primacial do colegiado parlamentar, a deliberativa. E deliberar mediante resultado dos votos efetivamente enunciados pelos membros do Poder Legislativo, não mais de forma ficta, por presunção, em decorrência da ausência dos votos; votos que lá se pressupunham proferidos, caso houvesse transcorrido in albis o prazo para apreciação dos projetos de lei em regime de urgência solicitado pelo Executivo, ou o prazo para deliberação dos projetos de lei vetados.

Os constituintes estaduais de 1988-9 buscaram elaborar as respectivas Constituições Estaduais observando os princípios da Constituição Federal, por expresso comando desta, sendo um deles o da efetiva deliberação, pelos membros do Poder Legislativo, das matérias submetidas ao crivo parlamentar. Princípio da efetiva deliberação, pois conformador de função essencial da representação política, a deliberativa.

Como resultado decorrente deste princípio constitucional, tem-se a inexistência do decurso de prazo no processo legislativo estadual. Contudo, ao disporem sobre a exigência de expressa deliberação, as Constituições Estaduais deram consequiências diversas para uma idêntica situação, no caso dos projetos de iniciativa do Governador, com solicitação de urgência, e com prazo de deliberação esgotado.

Nessas hipóteses, "se a Assembléia Legislativa não deliberar em até quarenta e cinco dias, o projeto será incluído na Ordem do Dia até que se ultime sua votação", é o que determinam as Constituições Estaduais do Acre (art. 54, § $5^{\circ}$ ), Goiás (art. 22, $\S 1^{\circ}$ ), Pernambuco (art. 21, § ${ }^{\circ}$ ), Rio Grande do Sul (art. 62, § $2^{\circ}$, após transcorridos 30 dias), Roraima (art. 42, § $1^{\circ}$ ) e São Paulo (art. 26, parágrafo único).

Já as Constituições de Alagoas (art. 88, § $1^{\circ}$ ), Amapá (art. 106, § $1^{\circ}$ ), Amazonas (art. 35, $\S 1^{\circ}$ ), Bahia (art. 79, $\S 1^{\circ}$ ), Espírito Santo (art. 65, $\S 1^{\text {o }}$ ), 
Maranhão (art. 46, § $1^{\circ}$ ), Mato Grosso (art. 41, § $1^{\circ}$ ), Mato Grosso do Sul (art. 69, § $1^{\circ}$ ), Minas Gerais (art. 69, $\left.\S 1^{\circ}\right)$, Pará (art. 107, $\S 1^{\circ}$ ), Paraná (art. 66, $\S 2^{\circ}$ ), Paraíba (art. 64, § 2º), Piauí (art. 76, parágrafo único), Rio de Janeiro (art. 114, § $1^{\circ}$ ), Rio Grande do Norte (art. 47, § $2^{\circ}$ ), Rondônia (art. 41, § $1^{\circ}$ ), Santa Catarina (art. 53, § $1^{\circ}$ ), Sergipe (art. 63, "caput") e Tocantins (art. 28, $\S 1^{\circ}$ ) estabeleceram que, transcorridos quarenta e cinco dias sem deliberação, o projeto será incluído em Ordem do Dia para que se ultime sua votação.

Não é de pouca monta a consequiência do disciplinamento constitucional dessa matéria, notadamente quando daí decorre a aplicação de normas regimentais que fixavam, ou fixam, em doze (art. 194, da XII CRI-SP), seis (art. 194, parágrafo único, da XIII CRI-SP), três (art. 131 do RI-GO) ou duas horas (art. 237 do RI-SC) o prazo para encerramento da discussão. A repercussão no procedimento legislativo pode envolver, dependendo do entendimento que se der aos comandos constitucionais (para que se ultime a votação / até que se ultime a votação), a supressão da própria fase de discussão do projeto, caso ela não se efetue no prazo dos quarenta e cinco dias iniciais.

Foi o que se deu na Assembléia Legislativa de São Paulo quando, em resposta a Questão de Ordem suscitada sobre essa matéria, o Presidente submeteu a votos, sem discussão, projeto que tramitara por mais de quarenta e cinco dias, em regime de urgência. ${ }^{272}$ Por sua direta relação com o tema desenvolvido, reproduzem-se, abaixo, excertos do conteúdo da Questão de Ordem:

"PRESIDENTE - DEP. VAZ DE LIMA - (...) Sabe-se que num processo, e também no processo legislativo evidentemente, há encadeamento de atos para se atingir determinado fim, trata-se de ação para "ir adiante", apontando sempre para um "caminho à frente", jamais estagnação, como a que se pode constatar mediante simples análise da atual Ordem do Dia [com 342 proposições]. A Assembléia Legislativa não pode subtrair, dela própria, como órgão colegiado que é, função finalística primordial preconizada pela Constituição: votar. Esta é, parece-me, a exegese dos dispositivos constitucionais citados. E é isto que devemos buscar, para o bem desta própria instituição parlamentar.

O legislador constituinte fixa prazo de 45 e de 30 dias para se obter a votação de cada proposição em regime de urgência (art. 26) e dos vetos (art. 28), respectivamente. Após o prazo fixado (45 e 30

\footnotetext{
${ }^{272}$ Projeto de Lei n. 633/2006, de autoria do Executivo, com solicitação de urgência constitucional. Incluído na Ordem do Dia em 14-11-06, foi, sem discussão, aprovado em 10-04-07. Transformou-se na lei n. 12.584, de 23-04-07: Autoriza a Fazenda do Estado a alienar, por doação, ao Município de Cruzeiro, imóvel com benfeitorias, que abriga o Museu Histórico e Pedagógico Major Novaes, devendo o Município manter a atual destinação do bem e promover a sua conservação.
} 
dias), determina que a proposição permaneça na Ordem do Dia para votação; não admitindo aprovação ou rejeição ficta de qualquer proposição, em clara indicação em ordem a valorizar o mandato representativo e o próprio Parlamento.

Essas razões sedimentam convicção de que, ao interpretar esses dispositivos constitucionais como impulsionadores do processo legislativo, esta Presidência estará indo ao encontro, igualmente, da intenção do legislador constituinte federal.

Desta forma, vencida a oportunidade de discussão e votação nos primeiros 30 dias ( $\S 5^{\circ}$ do art. 28 - veto) e nos primeiros 45 dias (parágrafo único do art. 26 - projetos de lei), passa-se adiante no processo, passa-se à fase da votação.

Acolhendo, pois, a questão de ordem da nobre Dep. Maria Lúcia Amary, decido, como orientação normativa, que, a partir da próxima sessão deliberativa desta Assembléia Legislativa, na organização da Ordem do Dia, os projetos de lei com urgência constitucional e os vetados, cujos prazos já ultrapassaram, respectivamente, 45 e 30 dias de tramitação pela Assembléia, deverão figurar na Ordem do Dia em fase de votação, e não mais em fase de discussão e votação." 273

$\mathrm{Na}$ hipótese de projetos de lei vetados, no entanto, há uniformidade nos comandos constitucionais. Todos determinam que, esgotado o prazo de trinta dias, sem deliberação, o veto deve ser incluído na Ordem do Dia da sessão imediata, sobrestandose as demais proposições, até sua votação final: Acre (art. 58, § $8^{\circ}$ ), Alagoas (art. 89,

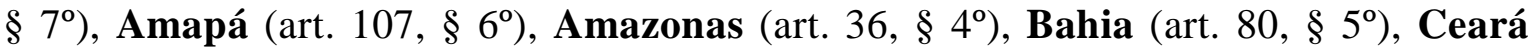
(art. 65, $\S 6^{\circ}$ ), Espírito Santo (art. 66, $\S 6^{\circ}$ ), Goiás (art. 23, $\S 5^{\circ}$ ), Maranhão (art. 47, $\S$ $5^{\circ}$ ), Mato Grosso (art. 42, § $7^{\circ}$ ), Mato Grosso do Sul (art. 70, $\S 6^{\circ}$ ), Minas Gerais (art. 70, $7^{\circ}$ ), Pará (art. 108, § $6^{\circ}$ ), Paraná (art. 71, $6^{\circ}$ ), Paraíba (art. 65, $\S 6^{\circ}$ ), Piauí (art. 78, $\S 6^{\circ}$ ), Pernambuco (art. 23, $\S 7^{\circ}$ ), Rio de Janeiro (art. 115, $\S 6^{\circ}$ ), Rio Grande do Norte (art. 49, § 5 ), Rio Grande do Sul (art. 66, § 6 ${ }^{\circ}$ ), Rondônia (art. 42, $\S 6^{\circ}$ ), Roraima (art. 43, $6^{\circ}$ ), Santa Catarina (art. 54, $\S 6^{\circ}$ ), São Paulo (art. 28, $\S 6^{\circ}$ ), Sergipe (art. 64, $\S 6^{\circ}$ ) e Tocantins (art. 29, $\S 6^{\circ}$ ). Ressalve-se, no entanto, que nem na Constituição do Estado de São Paulo e tampouco na de Roraima há alusão à figura do sobrestamento das demais proposições para deliberação das matérias vetadas.

\footnotetext{
${ }^{273}$ Questão de Ordem n. 237, respondida na $14^{\text {a }}$ sessão ordinária, 4-4-2007. Diário Oficial do Estado
} de São Paulo - Poder Legislativo, edição de 19-04-2007, p. 29-30. 


\section{CAP. 8 SANÇÃo, VETO, PROMULGAÇÃo E PUBLICAÇÃo NO PROCESSO DE FORMAÇÃO DAS LEIS}

Todas as Constituições Estaduais acompanham os postulados desse momento da fase constitutiva do processo de formação da lei previstos na Constituição Federal, que concede ao Executivo oportunidade para intervir apreciando, mediante sanção (aprovação) ou veto (rejeição), o projeto de lei já aprovado pelo Legislativo e remetido na forma de autógrafo ao Executivo.

\section{1 Autógrafo}

Pelo autógrafo o Presidente da Assembléia dá ciência ao Executivo do teor final da matéria aprovada pelo Legislativo, seja pelo Plenário ou por Comissão em sede deliberante. No autógrafo, o inteiro teor da redação final aprovada. Certifica-se pelo autógrafo o conteúdo do projeto de lei que deverá ser objeto da sanção ou do veto, e sua remessa implica confirmação, pela Assembléia Legislativa, da aprovação do projeto naquela final versão.

Se, decorrente da deliberação do Plenário, parte já suprimida do projeto for indevidamente mantida no autógrafo, haverá burla ao processo de formação das leis, e eventual sanção do Executivo sobre matéria já rejeitada pelo Parlamento e que, por equívoco, constara do autógrafo, não observará o devido processo legislativo e padecerá de necessária conformação com standard de constitucionalidade. ${ }^{274}$

\subsection{Sanção e vício de iniciativa}

Impende observar que, após a publicação do autógrafo do projeto de lei em diário oficial e sua remessa ao Executivo, o processo legislativo, até então escancaradamente público, mergulha no silêncio durante quinze dias úteis. Não há mais debates, discussões, tampouco consultas públicas. A deliberação monocrática do Executivo, mediante sanção ou veto, é ato de natureza legislativa no processo de formação de leis permeado, em regra, por atitude silente e aguardada (a deliberação do Executivo) com expectativa. As razões e contra-razões a fundamentar decisão deliberativa do Executivo são colhidas em ambientes reservados de áreas técnicas desse

${ }^{274}$ STF - ADI n. 1393-9/DF, rel. Min. Celso de Mello, Diário da Justiça, Seção I, 9-10-1996, p. 38.138 . 
Poder, ofuscando-se o princípio da publicidade que, até então, presidira o processo no âmbito do Poder Legislativo.

Contendo regra que contraria a posição atual do Supremo Tribunal Federal sobre sanção e convalidação de vício de iniciativa, a Constituição do Estado de Minas Gerais afirma que "a sanção expressa ou tácita supre a iniciativa do Poder Executivo no processo legislativo"(art. $70, \S 2^{\circ}$ ). Com o mesmo viés, a do Rio de Janeiro sustenta que "em caso de dúvida em relação às matérias de competência exclusiva do Governador do Estado, a sanção torna superado o possível vício de iniciativa" (art. 112, $\S 3^{\circ}$ ).

Essa questão remonta à Súmula n. 5 do Supremo Tribunal Federal quando, sob a égide da Constituição de 1946, pronunciando-se sobre a Lei n. 2.156, de 24 de setembro de 1959, do Município de Campinas-SP, e adotando a tese da convalidação, decidiu que a sanção de projeto [com iniciativa privativa usurpada por parlamentar] supre a falta de iniciativa do Poder Executivo ${ }^{275}$; mas, já em 1974 a Egrégia Corte decidira perfilhando a tese da não-convalidação, a de que a sanção não supre vício de iniciativa. ${ }^{276}$ Em homenagem a preceitos constitucionais do processo legislativo, em especial ao de que há fases procedimentais para formação da lei, dentre elas a da discricionária iniciativa em matérias de competência reservada previstas constitucionalmente, o Supremo Tribunal Federal mantém entendimento de que a usurpação - mediante projeto de lei ou por intermédio de emenda parlamentar - de iniciativa privativa não admite convalidação mediante sanção do Executivo. ${ }^{277}$

De fato. Como salienta Alexandre de Moraes, o vício de iniciativa "macula de nulidade toda a formação da lei, não podendo ser convalidado pela futura sanção presidencial". 278

Oportunas as observações de João Jampaulo Júnior ao concluir longo e aprofundado exame sobre o assunto:

\footnotetext{
${ }^{275}$ STF, Pleno, RMS-9619/SP, rel. Min. Victor Nunes, j. 20-8-1962. DJU de 18-10-1962.

STF, Pleno, MS-10890, j. 25-3-1963, DJU 30-5-1963, p. 342.

STF, $2^{\text {a }}$ Turma, RE-51238, rel. Min. Victor Nunes, j. 16-4-1963, DJU de 8-8-1963.

${ }^{276}$ Repr. 890-GB, RTJ 69/625 e s.

277 STF, ADI/MC n. 1.060-RS, rel. Min. Carlos Velloso, DJU, edição de 23-9-1994, p. 25.313.

STF, Pleno, ADIMC 1070/MS, rel. Min. Celso de Mello, j. 23-11-1994, DJU de 15-9-1995.

STF, Pleno, ADI 1963-5/PR, rel. Min. Maurício Corrêa, j. 18-3-1999, DJU de 7-5-1999.

STF, Pleno, ADI 700/RJ, rel. Min. Maurício Corrêa, j. 23-5-2001, DJU de 24-8-2001.

${ }^{278}$ Direito constitucional. 21. ed. São Paulo: Atlas, 2007, p. 624.
} 
"É comum nas Casas Legislativas, especialmente em sede estadual e municipal, o argumento de que não existe qualquer impedimento a que se invada seara de competência reservada. A sanção do Executivo seria o instrumento hábil para retirar a mácula causada pela usurpação da iniciativa.

É clara a intenção de alguns membros do Parlamento de criar situações insustentáveis e fatos políticos, notadamente em temas envolvendo o funcionalismo público - criação de cargos, funções, aumento de vencimentos e outros.

As matérias pertinentes ao funcionalismo - importantes para a Administração, que necessita de servidores qualificados e bem pagos podem render, noutro giro, dividendos eleitorais para políticos menos preparados. As pressões são muitas. Sabedoria do constituinte elencar essas matérias na competência reservada do Executivo". ${ }^{279}$

Não se coadunam, pois, com os postulados que regem o princípio da separação de poderes, tampouco com a jurisprudência atual da Suprema Corte os dispositivos das Constituições Estaduais mineira e fluminense sustentando que a sanção do Executivo supre o vício de usurpação da iniciativa reservada. $O$ dispositivo da Constituição do Rio de Janeiro ( $\$ 3^{\circ}$ acrescentado ao art. 112), aliás, foi promulgado recentemente, em 31 de maio de 2006, pela Emenda Constitucional n. 38.

\subsection{Reapreaciação pelo Poder Legislativo da matéria vetada}

Se, contudo, o Governador do Estado considerar o projeto, no todo ou em parte, inconstitucional ou contrário ao interesse público, oporá veto, total ou parcial, no prazo de quinze dias úteis, contados da data do recebimento, e comunicará os motivos do veto ao Presidente da Assembléia Legislativa dentro de quarenta e oito horas. Alexandre de Moraes observa, como característico do veto, que deve ser sempre expresso, motivado e supressivo, pode ser total ou parcial e superável pelo Legislativo, por isso mesmo relativo. ${ }^{280}$ Como já anotado no capítulo 2, mesmo quando a Constituição Federal de 1891 não admitia veto parcial (art. 37), o que só viria a ocorrer com a reforma de 1926, as Constituições Estaduais da Bahia (art. 41), Ceará (art. 33), Maranhão (art. 27, § 2º ) Pará (art. 29) adotavam-no para proposições orçamentárias; e a Constituição mineira (art. 38, § $2^{\circ}$ ) ampliava-o para outras matérias, além da orçamentária.

\subsubsection{Obrigatoriedade do escrutínio secreto?}

${ }^{279}$ O processo legislativo - sanção e vício de iniciativa. São Paulo: Malheiros, 2008, p. 136.

280 Direito Constitucional. 21. ed., São Paulo: Atlas, 2007, p. 632-633. 
Da mesma forma, em 1989, sem se afeiçoar ao processo legislativo federal, os constituintes gaúchos (art. $66, \S 4^{\circ}$ ) e paulistas (art. $28, \S 5^{\circ}$ ) adotaram, como regra para votação de matéria vetada, o escrutínio aberto, a deliberação ostensiva, e não o escrutínio secreto como previsto na Constituição Federal (art. 66, § 4º); ao depois foram acompanhados pelos constituintes dos Estados do Acre (art. 58, § $4^{\circ}-$ EC n. 10/95), do Rio de Janeiro (art. 115, § $4^{\circ}$ - EC n. 18/2001) e do Maranhão (art. 47, § $3^{\circ}$ EC n. 35/2002). Aliás, o legislador regimental rio-grandense-do-sul acentuou que a deliberação dar-se-á em votação nominal, não admitindo sequer a votação simbólica nessa hipótese (art. 216).

Como reserva de Plenário, a reapreciação de projeto vetado pelo Executivo não pode ser delegada a Comissão ou Comissões. A matéria vetada ou, de outro modo, o veto oposto pelo Governador só pode ser reapreciado se submetido aos votos dos membros da Assembléia Legislativa, e não prevalecerá se maioria absoluta dos parlamentares assim decidir.

Diz-se que um escrutínio secreto garantiria a independência dos congressistas, presumivelmente os da base de sustentação do governo com seus passos acompanhados pelos tentáculos vigilantes do Leviatã-Executivo. Mas, a regra gaúcha e paulista de votação aberta mostra-se mais consentânea com os princípios democrático e republicano. ${ }^{281}$ De fato, na esfera pública as decisões devem, tout court, ser públicas, por todos acompanhadas. Fernanda Dias Menezes de Almeida, em análise sobre a aplicação ao Poder Legislativo do princípio da publicidade na Constituição de 1988, acentua o interesse dos cidadãos em acompanhar como seus representados votam, e salienta:

"O fato é que o exercício do mandato político pressupõe coragem cívica que leve ao enfrentamento das pressões - afinal, elas fazem parte do processo político -, cabendo ao eleito enfrentá-las publicamente, e não, a pretexto de livrar-se delas, instalar-se sob o manto confortável do sigilo.

(...) faz parte dos encargos da representação exteriorizar suas posições, em tudo o que respeite ao que é de interesse público, mesmo em situações mais delicadas, em que possa sentir-se pouco à vontade, por poder ferir a suscetibilidade de seus pares (como no julgamento de

\footnotetext{
281 Acompanhada depois pela Assembléia Legislativa do Paraná, mediante Emenda Constitucional n. 17, de 08-11-2006: “Art. 56 - Salvo disposição constitucional em contrário, as deliberações da Assembléia Legislativa e de suas comissões serão tomadas por maioria de votos, presente a maioria absoluta de seus membros. Parágrafo único - Não será permitido o voto secreto nas deliberações do processo legislativo."
} 
um deles) ou do governo (quando entender necessário rejeitar o veto). Afinal, são os ossos do ofício. Por isso mesmo é que a coragem deve constar da bagagem dos representantes."282 (negritou-se)

\subsubsection{Deliberação sobre o veto ou sobre o projeto vetado?}

Aliás, a regra paulista manteve também a reapreciação do Legislativo pelo viés da apreciação do projeto $^{283}$, ao contrário da sistemática da Constituição Federal em vigor em que se reaprecia o veto oposto. ${ }^{284}$ Sob a perspectiva da reapreciação do projeto pelo viés do veto, os parlamentares votam a favor ou contra o veto: "Estará, então, mantido o veto, portanto, rejeitado o projeto, se contra ele se manifestar maioria absoluta dos Deputados e Senadores - separadamente - em escrutínio secreto (Constituição, art. 66, $\S 4^{\circ}$ ). Assim, o projeto estará definitivamente aprovado se a maioria absoluta dos Deputados e Senadores rejeitar o veto. Não se reunindo contra o veto essa maioria absoluta em ambas as Casas, estará ele mantido e conseqüentemente

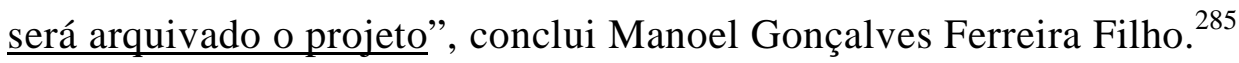

Já sob a perspectiva da reapreciação do projeto, os votos parlamentares são a favor ou contra o projeto. Corrobora-o, também, expressa norma regimental: “A votação não versará sobre o veto, mas sobre o projeto ou a parte vetada, votando Sim os que o aprovarem, rejeitando o veto, e Não os que o recusarem, aceitando o veto" (parágrafo único do artigo 233 da XIII Consolidação do Regimento Interno de SP).

A consequiência prática dessa relativização do ponto de vista do objeto da votação (projeto ou veto), é que, não se reunindo em favor do projeto de lei vetado maioria absoluta de votos para sua aprovação, mas se constatando como resultado da votação número de votos tendente à sua aprovação, norma regimental ${ }^{286}$ indica votação adiada do projeto, e não a sua rejeição ficta, como se dá na prática parlamentar congressual, e acima demonstrado no lógico raciocínio exposto por Manoel Gonçalves Ferreira Filho. No entanto, esse raciocínio tem como premissa praxe parlamentar de

\footnotetext{
${ }^{282}$ ALMEIDA, Fernanda Dias Menezes de. O sigilo no sistema democrático. In: YARSHELL, Flávio Luiz; MORAES, Mauricio Zanoide. (Org.) Estudos em homenagem à Professora Ada Pellegrini Grinover. São Paulo: DPJ, 2005, p. 237-238.

283 "Artigo $28-(\ldots) \S 5^{\circ}-$ A Assembléia Legislativa deliberará sobre a matéria vetada, em único turno de discussão e votação, no prazo de trinta dias de seu recebimento, considerando-se aprovada quando obtiver o voto favorável da maioria absoluta dos seus membros."

284 “Art. 66 - (..) $\S 4^{\circ}$ - O veto será apreciado em sessão conjunta, dentro de trinta dias a contar de seu recebimento, só podendo ser rejeitado pelo voto da maioria absoluta dos Deputados e Senadores, em escrutínio secreto."

${ }^{285}$ Do Processo Legislativo, $6^{\mathrm{a}}$ ed., p. 226-227.

286 “A votação dos projetos, cuja aprovação exija quorum especial, será renovada tantas vezes quantas forem necessárias, no caso de se atingir apenas maioria simples."
} 
considerar rejeitada proposição que, necessitando de quorum qualificado para sua aprovação, não venha a obtê-lo; em resultado que não reúne maioria de votos Não, onde, portanto, os votos Sim prevalecem sobre aqueles, em resultado tendente à aprovação. ${ }^{287}$ Nesse caso, ao invés de se proclamar como resultado, rejeitado o projeto e mantido o veto, dever-se-ia declarar adiada a votação. Isso em homenagem à regra fundamental das deliberações em colegiados, como são as do Legislativo: decisão pela maioria. Se a maioria não rejeita em resultado expresso da votação, a rejeição assim declarada é presumida, ficta, proveniente sim de interpretação.

\subsubsection{Destaques na votação da matéria vetada}

Como decorrência de a apreciação do veto ser ostensiva, indaga-se se seria facultado ao legislador, na reapreciação da matéria vetada, o destaque de expressões, tanto na apreciação de veto total quanto na de veto parcial. Registre-se, por primeiro, que se admite a rejeição parcial de veto total, mas aí a rejeição incidindo sobre texto integral de artigo, de parágrafo, de inciso ou de alínea. ${ }^{288}$ Admite-se, igualmente, a rejeição parcial de veto parcial, mas aí também incidindo a rejeição sobre texto integral de artigo, de parágrafo, de inciso ou de alínea. A essas situações Manoel Gonçalves Ferreira Filho já respondia: "Em relação ao veto parcial, ou a vetos parciais, não parece haver problema. A apreciação das disposições vetadas há de ser fragmentária, e nada obsta que o Congresso acolha as objeções contra frações do projeto e recuse outras". ${ }^{289}$ Em relação ao veto total: "Havendo a possibilidade de veto parcial, o veto total equivale à recusa de cada disposição do projeto. Ora, nada obsta logicamente que o Congresso reaprecie cada disposição do projeto de per si, ratificando umas, rejeitando outras". 290

A questão que se coloca agora é: pode haver destaque de expressões da matéria vetada, seja ela decorrente de veto total ou parcial?

Parece que sim, responde-se; e com supedâneo nas lições de Manoel Gonçalves Ferreira Filho: "a ratificação do projeto tem por conseqüência dispensar a anuência do Executivo. Como a sanção, torna-o lei perfeita e acabada. Daí se infere

\footnotetext{
${ }^{287}$ NÓBREGA NETTO, Miguel Jerônimo. O processo de votação no Parlamento Federal brasileiro. In: L \& C - Revista de Administração Pública e Política, n. 106, abr. 2007, p. 23-26.

${ }^{288}$ STF - Repr. 1.385, DJU de 20-9-1987, p. 20.411.

${ }^{289}$ Do Processo Legislativo, $6^{\mathrm{a}}$ ed., p. 227.

${ }^{290}$ Idem, p. 227-228.
} 
claramente que a concordância do Executivo é, em nosso Direito, dispensável, embora sua manifestação não o seja, para a transformação de um projeto em lei". ${ }^{291}$

Ora, como a manifestação do Executivo não foi dispensada, certifica-a o veto oposto, nada obsta que a Assembléia Legislativa reaprecie cada disposição do projeto de per si, de acordo, agora, com método regimental de votação, que admite, também, o destaque de expressões do projeto.

\subsection{Promulgação - Publicação}

Outra questão, agora atinente à hipótese de veto parcial com rejeição, pela Assembléia Legislativa, e conseqüente promulgação da matéria. José Afonso da Silva, na segunda edição do livro Processo Constitucional de Formação das Leis, reafirma que ainda haveria a seguinte prática:

"Projeto vetado em parte, rejeitado o veto. (...) No Estado de São Paulo, numa hipótese como essa, o Presidente da Assembléia Legislativa, sendo mantida a parte vetada, incorpora-se à parte sancionada e publicada, e promulga tudo de uma vez, mas com número diferente. De modo que a parte sancionada e promulgada pelo Governador toma uma numeração, depois com a queda do veto parcial e incorporação do texto à parte não vetada, já transformada em lei, promulga-se tudo com outra numeração, ficando a mesma lei com dois números, sem motivo justificado e, talvez, pelo equívoco de pensar que a parte sancionada não foi promulgada, o que não é certo; a verdade é que, com o procedimento usado, além da confusão da mesma lei com números diversos, uma parte foi duplamente promulgada por autoridades distintas: Governador e Presidente da Assembléia." 292

Ocorre que há muito assim não mais se procede. A parte vetada do projeto e novamente aprovada pela Assembléia com a conseqüente rejeição do veto é promulgada, tanto pelo Governador, como pelo Presidente da Assembléia ou pelo primeiro Vice-Presidente, com o mesmo número da lei relativa à parte sancionada do projeto, como se pode constatar em publicações oficiais. ${ }^{293}$

\footnotetext{
${ }^{291}$ Idem, p. 228.

292 Ob. cit., p. 241-242.

293 - Lei Complementar n. 857, de 20 de maio de 1999, publicada no Diário Oficial de 21 de maio de 1999, e a publicação da "parte vetada pelo senhor governador do Estado e mantida pela Assembléia Legislativa, do projeto que se transformou na Lei Complementar n. 857 (...) Faço saber que a Assembléia Legislativa decreta e eu promulgo, nos termos do artigo 28 , $8^{\circ}$, da Constituição do Estado, o seguinte dispositivo da Lei Complementar n. 857, de 20 de maio de 1999, da qual passa a fazer parte integrante:" Publicada em 11-12-1999, Diário Oficial do Estado - Poder Legislativo, p. 1 .
} 
Contudo, independentemente de a votação ser ostensiva ou secreta, com ou sem destaque, imperioso que haja deliberação do Legislativo sobre a matéria vetada. De fato, a ausência de deliberação, sobretudo nos vetos parciais, propicia incerteza e insegurança jurídicas. Aliás, constata-se um substancial déficit deliberativo, tanto de Assembléias Legislativas, como a paulista, e.g., quanto do Congresso Nacional concernente aos vetos opostos pelo Executivo. No Congresso, pendente de análise, há "140 projetos de lei vetados, perfazendo 881 partes sobres as quais incidiu a negação do Poder Executivo. Se à cifra aditarmos 18 projetos de lei com 178 dispositivos vetados, nem sequer lidos, conforme exige o regimento comum do Congresso, o total de proposições que tiveram negada a aprovação pelo Executivo atinge número talvez sem precedente na história do Parlamento: 158 projetos de lei e 1.059 partes a serem apreciados". 294 Na Assembléia Legislativa do Estado de São Paulo remanesciam na Ordem do Dia da última sessão de 2008, para apreciação, mais de quatrocentos projetos de lei vetados, alguns de 1995 (itens 32, 33 e 34). ${ }^{295}$ Todavia, ao contrário do que ocorre nas sessões congressuais, não há o sobrestamento da deliberação de outras proposições, ou seja, não há 'trancamento' das outras matérias da Ordem do Dia, resolvendo-se a primazia de uma proposição sobre outra, para discussão e votação, mediante requerimento de preferência, regimentalmente previsto.

Lei n. 10.710, de 29 de dezembro de 2000, publicada no Diário Oficial de 30 de dezembro de 2000, e a publicação das "partes vetadas pelo senhor governador do Estado e mantidas pela Assembléia Legislativa, do projeto que se transformou na Lei n. 10.710 (...) Faço saber que a Assembléia Legislativa decreta e eu promulgo, nos termos do artigo $28, \S 8^{\circ}$, da Constituição do Estado, os seguintes dispositivos da Lei n. 10.710, de 29 de dezembro de 2000, da qual passam a fazer parte integrante:". Publicada no Diário Oficial do Estado - Poder Legislativo, p. 1.

${ }^{294}$ MACIEL, Marco. Veto e insegurança jurídica. Folha de S. Paulo, edição de 27-9-2007, p. A-3.

${ }^{295} \mathrm{Na}$ última sessão ordinária de 2008 constavam na Ordem do Dia 432 projetos de lei vetados. Fonte: Secretaria Geral Parlamentar da Assembléia Legislativa do Estado de São Paulo. Diário Oficial do Estado - Poder Legislativo, edição de 18-12-2008, p. 8-15. 


\section{CONCLUSÕES}

Partiu-se da premissa de que a Constituição de 1988 não mais impõe, de forma expressa, a compulsória observância do processo legislativo federal ao constituinte estadual. De fato, a ordem constitucional imediatamente anterior, em incontestável anti-federalismo, determinava incorporação automática ao direito constitucional legislado dos Estados, das disposições nela constantes. Ademais, impunha expressamente a obrigatória observância do princípio do processo legislativo.

O processo legislativo federal remanesce agora como princípio implícito e, se remanesce como princípio implícito, os Estados-membros não estão obrigados à observância dessa implícita limitação à sua própria autonomia; máxime enquanto padrão normativo a ser simetricamente adotado por eles. A essas conclusões, perfilhada também por uma corrente de juristas com acentuado matiz federalista, decisões majoritárias do Supremo Tribunal Federal não se filiaram, ainda; todavia, já há dissidências, como a do Min. Menezes Direito, entendendo que o princípio da simetria deve comportar modulação e, acompanhado pela Ministra Cármen Lúcia, “considerou que a legislação ordinária no âmbito federal, que dispensa o quorum mais rigoroso da lei complementar, não impede que, na competência dos Estados-membros, seja possível exigir lei complementar. Frisou que a força da Federação brasileira deve estar exatamente na compreensão de que os Estados-membros podem fazer opções constitucionais locais com os padrões normativos disponíveis na Constituição Federal sem que isso malfira, em nenhum aspecto, qualquer princípio sensível ou qualquer limitação expressa ou implícita, e concluiu não vislumbrar razão alguma para a aplicação alargada do aludido postulado". ${ }^{296}$ É posição diametralmente oposta à do Min. Maurício Corrêa: "pertenço à corrente segundo a qual, sobretudo em tema de elaboração de norma constitucional, havendo disposição expressa na Constituição que

${ }^{296} \mathrm{STF}$ - Informativo n. 526. 
determine um certo parâmetro, os Estados-membros têm de obedecer a esse princípio. Do contrário, o Poder Legislativo dos Estados se transformaria numa verdadeira balbúrdia" (ADI 486/DF).

Pressupondo que o processo legislativo estadual não precisa ser mera transcrição do federal, procedeu-se neste estudo à análise e avaliação das Constituições Estaduais e dos Regimentos Internos das Assembléias Legislativas. Nelas fundamentadas e justificadas, apresentam-se, então, as conclusões finais.

Os constituintes estaduais procuraram conceder ao processo legislativo estadual alguma peculiaridade. De fato, embora não tenham criado espécies legislativas novas, algumas Constituições Estaduais deixaram, no entanto, de adotar todas as espécies legislativas previstas na Constituição Federal, o que, contrario sensu, também se contrapõe aos "simetristas", adeptos da aplicação da compulsória simetria do processo legislativo federal ao estadual. Com efeito, os Estados deixaram de adotar espécies legislativas que, como a medida provisória e a lei delegada, implicam capitis diminutio para a função legiferante do Poder Legislativo. Acre, Espírito Santo, Maranhão, Paraíba, Piauí, Rio Grande do Sul, Santa Catarina, São Paulo e Tocantins não adotaram, ainda, o regime de leis delegadas. Mas, tão-só Acre, Maranhão, Paraíba, Piauí, Santa Catarina e Tocantins já podem editar medidas provisórias. Três Estados, ao menos, não acentuando o fortalecimento da função legislativa do Executivo, deixaram de adotar o regime das leis delegadas e o das medidas provisórias: Espírito Santo, Rio Grande do Sul e São Paulo. Como no ordenamento constitucional imediatamente anterior somente Acre, Mato Grosso, Rio de Janeiro e São Paulo não adotavam o regime de leis delegadas e estavam proibidos de adotar o decreto-lei, vê-se que apenas São Paulo continuou mantendo postura de fortalecimento do Poder Legislativo nesse aspecto.

O constituinte mineiro não prevê como espécie legislativa do processo legislativo estadual o projeto de decreto legislativo.

Distanciando-se do paradigma federal, que não admite a iniciativa popular com titularidade para deflagrar o processo de alteração da Constituição da República, quatorze Estados admitem-na já para proposta de emenda constitucional estadual: Acre, Alagoas, Amapá, Amazonas, Bahia, Espírito Santo, Goiás, Pará, Paraíba, Pernambuco, Rio Grande do Sul, Roraima, Santa Catarina, São Paulo e Sergipe. Fortes, certamente, na convicção de que o rol de titulares para propor emenda à Constituição Federal não é 
principiológico, tratando-se de regra da norma que prevê um processo para mudança constitucional, esta sim fulcral, principiológica, corolário da concepção de uma Constituição rígida, porém mutável, exceto em relação ao seu cerne fixo, inabolível. Os constituintes dos Estados supra mencionados optaram, então, por conceder aos detentores diretos do poder o direito de iniciar o processo de alteração constitucional. Todavia, em flagrante exuberância, o constituinte paraense também outorgou ao seu Tribunal de Justiça igual atribuição. E, com impróprio viés restritivo, a Constituição de Roraima exige subscrição de, no mínimo, dois terços dos Deputados Estaduais para proposta de emenda constitucional, e a do Rio Grande do Norte prevê tão-só dois titulares para idêntica finalidade: Governador e, no mínimo, um terço dos Deputados Estaduais.

Sem qualquer simetria com o modelo federal também, que exigiria, in casu, a participação das Assembléias Legislativas, o constituinte do Rio Grande do Sul, zeloso de sua autonomia para dispor sobre regras no processo legislativo estadual, concede às Câmaras Municipais titularidade concorrente para apresentação de projetos de lei ordinária e complementar ao processo legislativo estadual.

Como arautos do princípio democrático e do republicano, os constituintes gaúchos e paulistas de 1989, e depois, mediante emendas, os acreanos, os maranhenses e os fluminenses, aprofundaram a aplicação do princípio da publicidade no processo legislativo estadual, não adotando, tal qual previsto na Constituição Federal, o escrutínio secreto para apreciação do veto. Nas Assembléias Legislativas desses Estados os cidadãos podem acompanhar como seus representantes decidem, na esfera pública, assuntos de interesse público constantes de vetos opostos pelos Governadores, eis que a votação aí é ostensiva. Não só. O constituinte paulista, ao contrário da sistemática da Constituição Federal em vigor, manteve como regra a veto oposto pelo Governador, a reapreciação do Legislativo pelo viés da reapreciação do projeto; diverso, pois, do processo legislativo federal, que se dá pelo viés da reapreciação do veto oposto. A conseqüência prática dessa relativização do ponto de vista do objeto da votação (projeto ou veto) está imbuída de efetivo fortalecimento do Legislativo. De fato, não se reunindo em favor do projeto de lei vetado maioria absoluta de votos para sua aprovação, mas se constatando como resultado da votação número de votos tendente à sua aprovação, norma regimental indica votação adiada do projeto, e não a 
sua rejeição ficta, como ocorre na prática parlamentar congressual, que se dá pela perspectiva da deliberação do veto.

Outra peculiaridade do processo legislativo estadual é a não adoção da regra de sobrestamento das demais proposições constantes de Ordem do Dia, quando incluídos os projetos de lei vetados e os projetos de autoria do Governador com solicitação de urgência constitucional, como determinado pela Constituição da República para o processo legislativo federal. O sobrestamento de proposições preterição do andamento das demais proposições que figuram na Ordem do Dia em benefício somente dos projetos de autoria do Executivo, com solicitação de urgência constitucional - é regra que informa um procedimento legislativo, o sumário, não se constituindo em princípio constitucional. De modo que, ao não adotarem o sobrestamento de proposições, os constituintes paulistas e roraimenses admitiram figurar na Ordem do Dia de suas Assembléias Legislativas, juntos, sem primazia, tanto os projetos de lei de iniciativa governamental, com solicitação de urgência prevista constitucionalmente, como também os demais projetos de autoria outra, que não a governamental, e que igualmente tramitam em regime de urgência, mas a urgência já prevista por norma regimental e decorrente de aprovação do Plenário da Assembléia ou a resultante de enquadramento automático nesse regime de tramitação pelo próprio legislador regimental.

Ao contrário da Constituição Federal, que admite, sem restrição de matéria (exceto código), solicitação de urgência do Presidente da República para apreciação de projetos de sua iniciativa, Constituições Estaduais restringiram o alcance da discricionariedade dos Governadores na solicitação de urgência a projetos de sua iniciativa, não admitindo a sua aplicação para projetos de lei complementar (Amazonas, art. 35, $\S 2^{\circ}$; Espírito Santo, art. 65, $2^{\circ}$; Mato Grosso, art. 41, $\S 2^{\circ}$; e Paraíba, art. 64, $\S 4^{\circ}$ ); para projeto de lei orgânica e estatuto (Acre, art. 54, § $3^{\circ}$; Pará, art. $107, \S 2^{\circ}$; e Paraná, art. 66, $\S 3^{\circ}$ ); orçamento (Bahia, art. $79, \S 2^{\circ}$ ); e para projeto "que dependa de quorum especial para aprovação; de lei orgânica, estatutária ou equivalente a código; e a projeto relativo a plano plurianual, diretrizes orçamentárias, orçamento anual ou crédito adicional" (art. 69, § $2^{\circ}$, da Constituição de Minas Gerais). Como se vê, o constituinte mineiro foi o que mais limitou o rol dos projetos que podem ser submetidos ao procedimento legislativo sumário. O cerceamento das opções de 
discricionariedade do Executivo para solicitação de urgência fortalece o alvedrio do Legislativo para disciplinar regimentalmente o trâmite de matérias de tal jaez.

Previsto no Regimento Interno da Assembléia Legislativa de Rondônia e no Regimento Comum do Congresso Nacional, o voto de liderança, por implicar delegação indevida do poder-dever de votar imputado a cada representante parlamentar, individualmente, subtrai atribuição essencial do mandato parlamentar, traduzida no voto individual. O voto parlamentar plúrimo dá supedâneo ao mandato parlamentar imperativo, inadmitido pelo constituinte brasileiro, que o pressupõe livre: "Os Deputados e Senadores são invioláveis, civil e penalmente, por quaisquer de suas opiniões, palavras e votos" (art. 53, caput, da CF). E esse preceito aplica-se, ex vi do art. 27, $\S 1^{\circ}$, da Constituição Federal, aos Deputados Estaduais.

Da mesma forma, impropriamente, a Constituição do Estado de Minas Gerais afirma que "a sanção expressa ou tácita supre a iniciativa do Poder Executivo no processo legislativo" (art. $70, \S 2^{\circ}$ ). E, com o mesmo viés, a do Rio de Janeiro sustenta que, "em caso de dúvida em relação às matérias de competência exclusiva do Governador do Estado, a sanção torna superado o possível vício de iniciativa" (art. 112, § $3^{\circ}$ ). Essas disposições constitucionais não se coadunam com o princípio da supremacia da Constituição. Atos legislativos contrários à Constituição não têm qualquer força de contrariá-la (Marbury v. Madison), são nulos. In casu, pela inobservância de requisito formal concernente ao atributo de deflagrar o processo legislativo acerca de matéria cuja iniciativa a Constituição impôs reserva.

Os dispositivos que prevêem o voto de liderança deveriam ser suprimidos, tanto do Regimento Interno da Assembléia Legislativa de Rondônia (art. 218) quanto do Regimento Comum do Congresso Nacional (art. 45). A mesma sorte dever-se-ia impingir a dispositivos da Constituição de Minas Gerais e do Rio de Janeiro que, ainda recalcitrantes, usurpam a reserva de competência legislativa constitucionalmente prevista.

Constata-se, outrossim, que a possibilidade de realização de sessões secretas nas Casas Legislativas congressuais, tal qual permitido pelo modelo federal, afasta do padrão republicano aquelas sessões legislativas, estando mais próximos do cânone republicano os preceitos de Constituições estaduais, que só admitem sessões plenárias públicas, jamais secretas. Sob a perspectiva de que os constituintes estaduais podem se tornar arautos de novas experiências no sistema federativo, induzindo, inclusive, a 
melhores práticas no processo legislativo, pode-se reconhecer as vantagens, como as in casu, de não se impingir aos Estados-membros padrões de incondicional observância do processo legislativo federal. 


\section{BIBLIOGRAFIA}

ALMEIDA, Fernanda Dias Menezes de. Competências na Constituição de 1988. São Paulo: Atlas, 4. ed., 2007.

O sigilo no sistema democrático. In: YARSHELL, Flávio Luiz; MORAES, Mauricio Zanoide. (Org.) Estudos em homenagem à Professora Ada Pellegrini Grinover. São Paulo: DPJ, 2005, p. 237-238.

O Poder Legislativo e suas atribuições no Estado contemporâneo. In: Revista Jurídica 9 de Julho. São Paulo: Alesp, n. 2, 2003, p. 213-221.

Atividade constituinte nos Estados e nos Municípios. In: Revista Jurídica 9 de Julho. São Paulo: Alesp, n. 3, 2004, p.65-85.

ALVAREZ, Elviro Aranda. Los actos parlamentarios no normativos y su control jurisdiccional. Madri: Centro de Estudios Políticos y Constitucionales, 1998.

ATALIBA, Geraldo. República e Constituição. São Paulo : Ed. RT, 1985.

AVRIL, Pierre; GICQUEL, Jean. Droit Parlementaire. Paris : Ed. Montchrestien, 1996.

AZEVEDO, Luiz H. Cascelli de. O controle legislativo de constitucionalidade. Porto Alegre: Fabris Ed., 2001.

AZEVEDO, Márcia Maria Corrêa de. Prática do Processo Legislativo. São Paulo: Atlas, 2001.

BISCARETTI DI RUFFIA, Paolo. Direito constitucional : instituições de direito público. São Paulo : Ed. Revista dos Tribunais, 1984.

BOBBIO, Norberto; MATTEUCCI, Nicola; PASQUINO, Gianfranco. Dicionário de Política. São Paulo : Imprensa Oficial do Estado, 5. ed., 2000.

BOBBIO, Norberto. Teoria Geral da política: a filosofia política e as lições dos clássicos. Trad. Daniela Beccaccia Bersiani, Rio de Janeiro : Campus, 2000.

BONAVIDES, Paulo. Ciência Política. São Paulo : Malheiros, 10 ed., 2002.

BRITTO, Luiz Navarro de. História dos parlamentos: um esboço, in Revista de Informação Legislativa, Brasília : Senado Federal, a. 21, n. 81, jan./mar. 1984

BURDEAU, Georges. $O$ Estado. Tradução Maria Ermantina de Almeida Prado Galvão. São Paulo: Martins Fontes, 2005.

BURKE, Edmund. Textos politicos. México, D.F. : Fondo de Cultura Economica, 1942.

CAggIANO, Monica Herman Salem. Direito Parlamentar e Direito Eleitoral. Barueri-SP : Manole, 2004.

Federalismo incompleto, descentralização e indefinição de competências. Revista Direito Mackenzie. São Paulo: Editora Mackenzie, 2000, p. 3248.

CAliman, Auro Augusto. Mandato Parlamentar: aquisição e perda antecipada. São Paulo: Atlas, 2005. 
CANTIZANO, Dagoberto Liberato. $O$ processo legislativo nas Constituições brasileiras e no Direito comparado. Rio de Janeiro: Forense, 1985.

CARVALHO, João Soares. Antecedentes da História Parlamentar Britânica. Lisboa: Horizonte, 1989.

CARVALHO, Kildare Gonçalves. Técnica Legislativa. 4. ed. Belo Horizonte: Del Rey, 2007.

CAVALCANTI, João Barbalho Uchôa. Constituição Federal Brasileira (1891): comentada. Ed. Fac-similar. Brasília: Senado Federal, Conselho Editorial, 2002.

CATTONI, Marcelo. Devido processo legislativo. Belo Horizonte: Mandamentos, 2000 .

CLEMENTE, Roberta. Variações de Presidencialismos na Federação brasileira: processo político e reforma nos Estados, 1995-2006. São Paulo: FGV (Doutorado), 2007.

CIOLO, Vittorio di, CIAURRO, Luigi. Il Diritto parlamentare nella teoria e nella pratica. Milão: Giuffrè Ed., 4 ed., 2003.

COELHO, Fábio Alexandre. Processo legislativo. São Paulo: Juarez de Oliveira, 2007.

DALLARI, Dalmo de Abreu. Elementos de Teoria Geral do Estado. São Paulo : Saraiva, 6. ed., 1979.

DINAN, John J. The American state constitucional tradition. Lawrence: University Press of Kansas, 2006.

DOMINGUES, Francisco Caamaño. El mandato parlamentario. Madri: Congreso de los Diputados, 1991.

FERRARI, Sergio. Constituição Estadual e Federação. Rio de Janeiro: Lumen Juris, 2003.

FERRAZ, Anna Cândida da Cunha. Poder constituinte do Estado-membro. São Paulo: Rev. dos Tribunais, 1979.

União, estados e municípios na nova constituição: enfoque jurídico-formal.

A nova constituição paulista. São Paulo: Fundação Faria Lima/Fundação de Desenvolvimento Administrativo, 1989.

FERRAZ JR. Tércio Sampaio. Democracia e Participação, in Curso de Introdução à Ciência Política. Brasília : Editora Universidade de Brasília, 1979.

Princípios condicionantes do poder constituinte estadual em face da Constituição Federal. In: RDP, n. 92, p. 39-46.

FERREIRA FILHO, Manoel Gonçalves. Comentários à Constituição Brasileira de 1988. São Paulo : Saraiva, 1990, v. 1.

Do Processo Legislativo. 6. ed. São Paulo : Saraiva, 2007.

Saraiva, 2003. Aspectos do direito constitucional contemporâneo. São Paulo:

et alii. Temas de Direito Constitucional Estadual. São Paulo: Assembléia Legislativa de São Paulo, 2004. 
FINER, S. E. A História do Governo: As épocas intermédias. Portugal: Publicações Europa-América, 2004.

FREIRE, Natália de Miranda. Técnica e processo legislativo: comentários à Lei Complementar n. 95/98. Belo Horizonte: Del Rey. 2002.

FRIEDRICH, Carl Joachim. Gobierno constitucional y democracia. Madrid : Instituto de Estudios Politicos, 2. Vol., 1975.

GARCIA, Rodolfo. Ensaio sobre a História Política e Administrativa do Brasil (15001810). Rio de Janeiro: José Olympio, 1956.

GILISSEN, John. Introdução histórica ao Direito. 3. ed. Lisboa : Fundação Calouste Gulbenkian, 2001.

GOLDWIN, Robert A., SCHAMBRA, William A. (Orgs.). A Constituição norteamericana. Rio de Janeiro: Forense Universitária, 1986.

HAMILTON, Alexander; MADISON, James; JAY, John. O Federalista. Brasília : Ed. Universidade de Brasília, 1984.

HONORATI, Maria Luisa Mazzoni. Diritto Parlamentare. Turim: G. Giappichelli Ed., 2. ed., 2005.

HORTA, Raul Machado. A autonomia do Estado-membro no Direito Constitucional Brasileiro. Belo Horizonte: Estabelecimento Gráfico Santa Maria, 1964.

et alii. Problemas do Federalismo. In Perspectivas do Federalismo Brasileiro. Belo Horizonte: Imprensa da Universidade de Minas Gerais, 1958.

Direito constitucional. 3. ed. Belo Horizonte: Del Rey, 2002.

JAMPAULO JÚNIOR, João. O processo legislativo - sanção e vício de iniciativa. São Paulo: Malheiros, 2008.

KELSEN, Hans. Teoria Geral do Direito e do Estado. São Paulo : Martins Fontes, 2000 .

LEMBO, Cláudio. Cronologia básica do Direito Eleitoral Brasileiro. In: LEMBO, Cláudio; CAGGIANO, Monica Herman Salem. (Coord.) O voto nas Américas. Barueri, SP: Minha Editora; São Paulo: Cepes, 2008, p. 73-106.

LOEWENSTEIN, Karl. Teoria de la Constitucion. Tradução de Alfredo Gallego Anabitarte. Barcelona : Ediciones Ariel, 1965.

LONGI, Vincenzo. Elementi di Diritto e procedura parlamentare. Milão: Giuffrè Ed., 1994.

MALBERG, R. Carré de. Teoría general del Estado. México : Fondo de Cultura Económica, 1998.

MARINHO, Josaphat. Poderes remanescentes na Federação brasileira. Bahia: Artes Gráficas, 1954.

MARTINS, Cristiano Franco. Princípio federativo e mudança constitucional. Rio de Janeiro: Lumen Juris, 2003.

MELlO FILHO, José Celso. Constituição Federal anotada. 2. ed., São Paulo : Saraiva, 1986.

MIRANDA, Francisco Cavalcanti Pontes de. Comentários à Constituição de 1967; com a Emenda n. 1 de 1969. 3. ed., Rio de Janeiro : Forense, 1987. 
MIRANDA, Jorge. Textos históricos do direito constitucional. 2. ed. Lisboa : Imprensa Nacional, 1990.

El proceso legislativo parlamentario em Portugal. Madri: Centro de Estudios Constitucionales, 1996.

MONTESQUIEU. Do Espírito das Leis. (Coleção Os Pensadores; Tradução de Fernando Henrique Cardoso e Leôncio Martins Rodrigues.) São Paulo : Abril, 1973.

MORAES, Alexandre de. Constituição do Brasil interpretada e legislação constitucional. São Paulo : Atlas, 2002.

. Direito Constitucional. 22. ed. São Paulo : Atlas, 2007.

. Direitos humanos fundamentais. São Paulo : Atlas, 1997.

Jurisdição constitucional e tribunais constitucionais: garantia suprema da Constituição. São Paulo: Atlas, 2000.

. Presidencialismo. São Paulo : Atlas, 2004.

et alii. Temas de Direito Constitucional Estadual. São Paulo: Assembléia Legislativa de São Paulo, 2004.

MOREIRA, Adriado; BUGAllo, Alejandro; AlbUQUERQUE, Celso. Legado Político do Ocidente - O Homem e o Estado. Rio de Janeiro : Difel, 1978,

MOURA, Francinira Macedo de. Direito Parlamentar. Brasília : Edit. Brasília Jurídica, 1992.

NEGRI, André Del. Controle de constitucionalidade no processo legislativo: teoria e legitimidade democrática. Belo Horizonte: Ed. Fórum, 2003.

NUNES, José de Castro. As Constituições Estaduaes do Brasil. Rio de Janeiro: Edit. Leite Ribeiro, 1922.

PAUlo, Vicente, ALEXANDRINO, Marcelo. Processo legislativo. Rio de Janeiro: Impetus, 2003.

PIMENTA BUENO, José Antonio. Direito Público Brasileiro $e$ análise da Constituição do Império. Rio de Janeiro : Ministério da Justiça e Negócios Interiores, 1958.

RIVEIRA, Rosa Maria Fernández. El voto parlamentario. Madri: Centro de Estudios Políticos y Constitucionales, 2003.

ROCHA, Cármen Lúcia Antunes. República e Federação no Brasil: traços constitucionais da organização política brasileira. Belo Horizonte: Del Rey, 1996.

ROMANO, Santi. Princípios de direito constitucional geral. São Paulo : Revista dos Tribunais, 1977.

ROURE, Agenor de. Formação constitucional do Brasil. Rio de Janeiro: Typ. do Jornal do Commercio, 1914.

A Constituinte Republicana. 2 vol. Rio de Janeiro: Imprensa Nacional, 1920.

ROUSSEAU, Jean-Jacques. $O$ Contrato Social. Tradução de Rolando Roque da Silva. São Paulo: Cultrix, 1971.

SARTORI, Giovanni. Teoria da representação no Estado representativo moderno. Belo Horizonte: Revista Brasileira de Estudos Políticos, 1962. 
SCHWARTZ, Bernard. Direito constitucional americano. Rio de Janeiro : Forense, 1966.

S.E.P.E.S. - Servicio Español del Professorado de Enseñanza Superior. $L a$ Estructura del Estado. Barcelona : Bosch Casa Editorial, 1958.

SIEYÈS, Emmanuel-Joseph. Qué es el Estado llano? Madrid : Centro de Estudios Constitucionales, 1988.

SILVA, José Afonso da. Curso de Direito Constitucional Positivo. São Paulo : Malheiros, 15 ed., 1998.

Princípios do processo de formação das leis no Direito Constitucional. São Paulo : Ed. Revista dos Tribunais, 1964.

Processo constitucional de formação das leis. São Paulo: Malheiros, 2006.

SILVA FILHO, Derly Barreto. Controle dos Atos Parlamentares pelo Poder Judiciário. São Paulo : Malheiros Edit., 2003.

SOUZA, Hilda de. Processo Legislativo. Porto Alegre: Sulina, 1998.

SPROESSER, Andyara Klopstock. Direito Parlamentar - processo legislativo. 2. ed. São Paulo: ALESP/SGP, 2004.

A Comissãos Parlamentas de Inquérito - CPI no Ordenamento Jurídico Brasileiro. São Paulo: Assembléia Legislativa de São Paulo, 2008.

TAVARES, André Ramos et alii. Temas de Direito Constitucional Estadual. São Paulo: Assembléia Legislativa de São Paulo, 2004.

TEMER, Michel. 18. ed. Elementos de Direito Constitucional. São Paulo: Malheiros, 2002.

TRIGUEIRO, Oswaldo. Direito Constitucional estadual. Rio de Janeiro: Forense, 1980.

VALENZUELA, Francisco Berlin. Derecho Parlamentario. México : Fondo de Cultura Económica, 1994.

VIEIRA JR., Ronaldo Jorge Araujo. O Supremo Tribunal Federal e o controle jurisdicional da atuação do Poder Legislativo: visão panorâmica e comentada da jurisprudência constitucional. Brasília: Senado Federal, Secretaria-Geral da Mesa, 2007.

WALDRON, Jeremy. A dignidade da legislação. São Paulo: Martins Fontes, 2003. 